Seton Hall University eRepository@Seton Hall

Seton Hall University Dissertations and Theses (ETDs)

Seton Hall University Dissertations and Theses

2008

\title{
An Investigation into Teacher Turnover in International Schools
}

Glenn Odland

Seton Hall University

Follow this and additional works at: https://scholarship.shu.edu/dissertations

Part of the Bilingual, Multilingual, and Multicultural Education Commons, and the Educational Administration and Supervision Commons

\section{Recommended Citation}

Odland, Glenn, "An Investigation into Teacher Turnover in International Schools" (2008). Seton Hall University Dissertations and Theses (ETDs). 212.

https://scholarship.shu.edu/dissertations/212 


\title{
AN INVESTIGATION INTO TEACHER TURNOVER IN INTERNATIONAL SCHOOLS
}

\author{
BY \\ GLENN ODLAND
}

\begin{abstract}
Dissertation Committee
Mary Ruzicka, Ph.D.

James Caulfield, Ed.D.

Mary Hayden, Ph.D.

Glenn Zederayko, Ed.D.
\end{abstract}

Submitted in Partial Fulfillment

of the requirement for the Degree of

Doctor of Education

Seton Hall University

2007 


\author{
SETON HALL UNIVERSITY \\ COLLEGE OF EDUCATION AND HUMAN SERVICES \\ OFFICE OF GRADUATE STUDIES
}

\title{
APPROVAL FOR SUCCESSFUL DEFENSE
}

Doctoral Candidate, Glenn Odland, has successfully defended and made the required modifications to the text of the doctoral dissertation for the Ed.D. during this Fall

Semester 2007.

\section{DISSERTATION COMMITTEE}

(please sign and date beside your name)

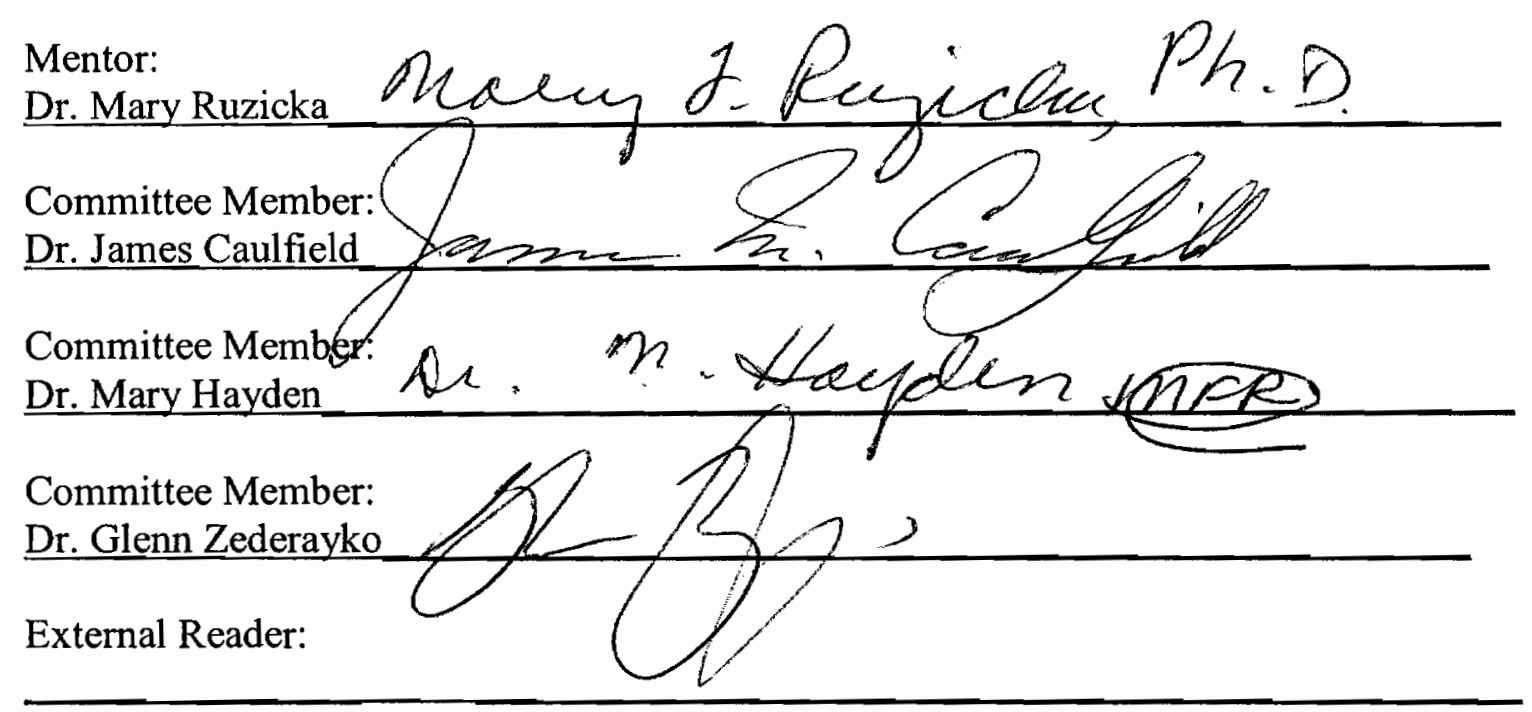

The mentor and any other committee members who wish to review revisions will sign and date this document only when revisions have been completed. Please return this form to the Office of Graduate Studies, where it will be placed in the candidate's file and submit a copy with your final dissertation to be bound as page number two. 
(C) Copyright by Glenn Odland, 2007 All Rights Reserved 


\section{ACKNOWLEDGEMENTS}

I want to begin by expressing gratitude to my advisor, Dr. Mary Ruzicka, for her steady guidance through this process. From the outset, she held me accountable to a standard of practice for conducting research that led to this finished product. Her most often repeated question is one I will not soon forget; "What does the literature say?" Answering this question proved to be the key to answering my own questions. Through the process, I gained great respect for the value of sound research.

I am also deeply grateful to my other dissertation committee members. Dr. JamesCaulfield's gentle and kind soul was a steady source of inspiration to continue along a path that had its occasional challenges! Dr. Mary Hayden graciously accepted an invitation to participate in this study even though we have not even met ...yet! She proved to be an invaluable resource in alerting me to the work that has been done in this field. I look forward to the day when I can visit the University of Bath (UK) and thank her in person. Dr. Glenn Zederayko demonstrated the depth of his friendship in giving sacrificially of his time to help me in this project. As a practicing Head of School (Toronto Montessori School) he took the time, often on very short notice, to provide valuable feedback and encouragement. To my entire committee, I say a heart-felt thank you.

To the members of Cohort IX, I acknowledge that your friendship, encouragement and support have been invaluable in completing this degree. The months we spent together were truly unforgettable, and the prospect of seeing you again was 
what it took to make me pack my bags and board yet another plane to come to New Jersey! Every minute of those rides was worth the time it bought me with you. Thank you for your love and friendship. God Bless each one of you.

I also want to acknowledge the critically important role played by Jim McKay and his team at the Council of International Schools. I deeply appreciate their help in disseminating the questionnaire to the teachers registered on their main placement database. Without that help, this study would not have been possible. The culture of collaboration and research demonstrated by CIS is nothing short of exemplary. 


\section{DEDICATION}

"Her children arise and call her blessed; her husband also, and he praises her: Many women do noble things, but you surpass them all."

Proverbs $31: 28,29$

My marriage to Deanna over 27 years ago was the beginning of a partnership that has permanently shaped my character and enriched my life. Together we have raised a family of whom we are deeply proud and whom we love with all our hearts. Together we have faced challenges that would have been overwhelming to deal with alone. Together we have completed this degree. Deanna's unconditional love, infinite support and irrational confidence in me have been the most powerful earthly force of my entire life. I consider myself the most blessed man on earth to know that we will continue to enjoy life together for as long as we both draw breath.

To Jeremy and Shannon, Kahlan and Monica, thank you for being the best family for which a father could ever wish. Your love for me continues to be a daily source of inspiration to be the best I can be.

To both my parents and Deanna's mom, thank you also for the love you have always showered on me. I can feel Dad McComish smiling down on me at this milestone event!

Surrounded as I am by loving family and friends, I count myself fortunate in the extreme. Thank you to each one of you. 


\section{TABLE OF CONTENTS}

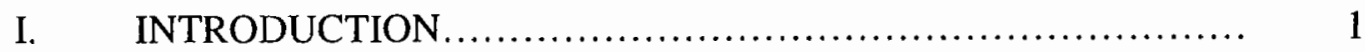

The Context of a Study Involving International Schools............ 2

Summary of the Problem....................................... 4

The Purpose of the Study......................................... 7

Main Research Question............................................ 7

Subsidiary Questions........................................... 8

Hypothesis................................................ 8

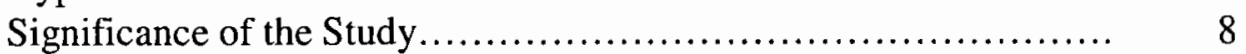

Limitations of the Study....................................... 11

Delimitations of the Study...................................... 13

Assumptions of the Study...................................... 14

Definition of Terms............................................ 14

Surnmary..................................................... 15

II. REVIEW OF RELEVANT LITERATURE ...................... 17

Context....................................................... 17

Teacher attrition and teacher turnover in the United States.......... 18

Causes of teacher turnover in US schools........................... 22

Teacher turnover studies from other countries..................... 32

Teacher turnover studies from international schools................. 37

Summary............................................... 41

III. METHODOLOGY ....................................... 43

Subjects.................................................. 43

Research Procedure............................................ 48

Data collection............................................... 48

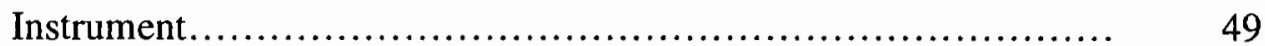

Data analysis................................................ 51

Additional purposes of Sections I and II....................... 53

Quantitative analysis.......................................... 55

Qualitative analysis........................................... 56

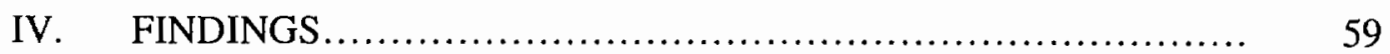

Overview..................................................... 59

Teacher characteristics......................................... 59 
Respondents' demographics compared against existing data.......... 60

Composite profile of respondents................................. 62

School characteristics............................................ 64

Composite profile of schools.................................. 67

Data analysis............................................... 68

Quantitative analysis...................................... $\quad 72$

Causal factors analyzed by associative factors............. $\quad 77$

Causal factors by school characteristics.................... $\quad 78$

Causal factors by teacher characteristics.................. $\quad 79$

Qualitative analysis............................................ 81

V. DISCUSSION AND CONCLUSION........................... 94

Main research question...................................... 94

Subsidiary research questions................................. 105

Subsidiary question a.)................................ $\quad 106$

Subsidiary question b.).................................. 107

Recommendations............................................. 110

Implications for international school administrators.......... 110

Recommendations for future study...................... $\quad 114$

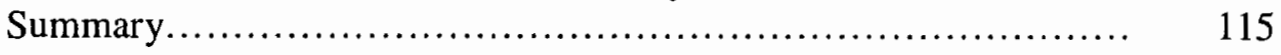

References............................................... 117

Appendices................................................. 127

Appendix A: Letter of Invitation........................... 127

Appendix B: Survey Instrument.......................... 130

Appendix C: Graphs displaying Teacher Characteristics..... 137

Appendix D: Quantitative Analysis Tables.................. 143

Appendix E: Participant Responses to Prompt Questions..... 185 


\section{LIST OF TABLES}

Table 1: CIS 2006 Teacher Demographics by gender..................... 46

Table 2: CIS 2006 Teacher Demographics by region of the world........... 46

Table 3: Construct Categories for survey data analysis.................... 51

Table 4: Teacher Demographics for survey respondents by gender.......... 60

Table 5: Demographics for survey respondents' nationalities............... 61

Table 6: Summary of Selected Teacher Characteristics..................... 63

Table 7: Demographics for schools represented by survey respondents...... 65

Table 8: Comparison of E/CIS 2006 survey countries vs. current study...... 66

Table 9: Comparison of E/CIS 2006 School Ownership vs. Current Study.... 66

Table 10: Programs offered in respondents' schools........................ 67

Table 11: Descriptive statistics for items comprising causal factors.......... 73

Table 12: Mean rank values for 18 statements comprising causal factors....... 76

Table 13: Test statistics for Friedman One-Way ANOVA................. 77

Table 14: Summary of differences in mean rank distributions of causal factors $\quad 79$

Table 15: Summary of differences in mean rank distributions of causal factors $\quad 80$

Table 16: Abbreviation legend for coding causal factors.................... 82

Table 17: Summary of comments for question $18 \ldots \ldots \ldots \ldots \ldots \ldots \ldots \ldots \ldots . . \ldots 3$

Table 18: Summary of comments for question 19 a...................... 84

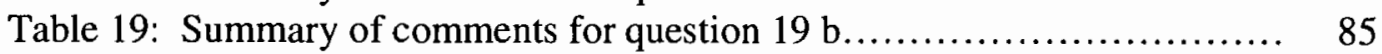

Table 20: Summary of comments for question 19 c....................... 87

Table 21: Summary of comments for question $21 \ldots \ldots \ldots \ldots \ldots \ldots \ldots \ldots \ldots . \quad 88$

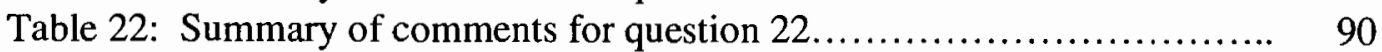

Table 23: Aggregated Type 1 comments from Tables 15 to $20 \ldots \ldots \ldots \ldots \ldots . . . \ldots 1$

Table 24: Aggregated Type 2 comments from Tables 15 to $20 \ldots \ldots \ldots \ldots \ldots . . . \ldots 3$

Table 25: Questionnaire statements with means greater than three............ 95

Table 26: Combined list of key causal factors, abbreviated.................. 111 


\section{LIST OF FIGURES}

Figure 1: School size.............................................. 68

Figure 2: Comparison of means of each causal factor.................... 75

Figure 3: Total years teaching experience.............................. 138

Figure 4: Years at school about which participant responded............... 138

Figure 5: Years at international schools................................. 139

Figure 6: Year in which respondent left school.......................... 139

Figure 7: Age of respondent...................................... 140

Figure 8: Marital status.............................................. $\quad 140$

Figure 9: Number of children living with respondent.................... 141

Figure 10: Education level........................................... 141

Figure 11: Main subject area of teaching............................... 142 


\section{CHAPTER I}

\section{INTRODUCTION}

A teacher's decision to leave a school can be viewed as a very personal choice, as indeed it is. However personal that choice may be, it does have an impact on the school the teacher has chosen to leave. Viewed in isolation, the departure of one teacher from a school may be considered to have a minimal impact. Nonetheless, when substantial numbers of teachers leave a school, the cumulative impact on the school grows to be debilitating (Ingersoll, 2001). While the numbers vary depending on the source, studies indicate that in the United States in recent years, somewhere between 16 to $20 \%$ of all teachers choose to leave the school in which they are teaching that year (E. Hanushek, 2004; Luekens, Lyter, \& Fox, 2004). It is little wonder that teacher retention has been identified as a national crisis in the United States (Hunt \& Carroll, 2003).

Given the scope and impact of the issue in the United States, a multitude of studies have been conducted to determine the causes behind the phenomenon of teacher retention. Many of these studies examine the issue of teacher retention with a specific focus on teachers who leave the profession (Buckley, Schneider, \& Shang, 2005; Eberhard, Reinhardt-Mondragon, \& Stottlemyer, 2000; Hansen, Lien, Cavalluzzo, \& Wenger, 2004; McCreight, 2000; Stinebrickner, 2001; Thornton, Peltier, \& Medina, 2007). Such studies look at teacher retention from a system perspective (eg. a school district, a state, or even the national level). These studies disregard the impact of teachers leaving any given school, and look only at the systemic issue of losing teachers from the overall pool available to staff schools. A subset of the teacher retention issue is that of 
teacher mobility, or teacher movement between schools or school systems, also known as teacher turnover. This subset issue and its impact on specific schools has also been studied in the context of U.S. schools (Davis, 2002; Elfers, Plecki, \& Knapp, 2006; E. A. Hanushek, Kain, \& Rivkin, 2001; Imazeki, 2002; Ingersoll, 2001; Ross, Stringfield, Sanders, \& Wright, 2003; Scafidi, Sjoquist, \& Stinebrickner; Vidal \& Xu, 1992). Less common are studies examining teacher turnover in countries other than the U.S. (Falch \& Ronning, 2005; Falch \& Strom, 2002; Rhodes, Nevill, \& Allan, 2004; Ritchie, 2004; Sargent \& Hannum, 2005; Webb et al., 2004). Such studies reveal strong consistency in findings among national studies, the specifics of which will be addressed by this researcher in a subsequent chapter. Most rare in the body of literature regarding teacher turnover and its impact on schools is that dealing with international schools (Cambridge, 2002; Hardman, 2001; Joslin, 2002). That does not mean that this phenomenon is not perceived to be an issue in such schools (Cambridge, 1998; Fink, 2001; Gillies, 2001). More accurately it points to the challenges embedded in conducting such a study.

The Context of a Study Involving International Schools International schools are highly independent institutions (Ortloff \& EscobarOrtloff, 2001). While they often belong to one or more organizations which offer a loosely structured connection to similar schools around the world, they do so by choice, and are free to withdraw when and if they so choose. Examples of such organizations are the International Baccalaureate Organization (IBO) (www.ibo.org), which offers three programmes that are popular among international schools. The Primary Years Programme (PYP) is designed for elementary students up to grade five, the Middle Years Programme (MYP) is designed for students from grades six to ten, and the Diploma 
Programme (DP) is designed for students in grades eleven and twelve. For a school to offer any of the three IB programmes, it must apply for authorization and be granted permission by the IBO. Thus, the IBO serves a regulatory function for international schools that choose to offer their programmes, but it only addresses variables that directly relate to the consistency and quality of the programme delivery. As of October 2007, the IBO works with 2132 schools in 125 countries serving 571,000 students ("International Baccalaureate Organization website", 2007).

Even less structured are two sister organizations, the European Council of International Schools (ECIS) and the Council of International Schools (CIS). While these two organizations offer accreditation services, it is not necessary to be accredited to join either of them. Regional associations of international schools also exist, such as the East Asia Regional Council of Overseas Schools (EARCOS). Such organizations generally exist in order to facilitate professional development, recognizing that it is much more cost effective to join economic forces in organizing workshops and conferences. While the above mentioned organizations seem to suggest that member schools share a high degree of similarity, that is decidedly not the case (Hayden \& Thompson, 1998). For example, in the combined E/CIS community of schools, the majority of its membership is comprised of schools with students from 25 or more nationalities, but there are schools with student populations of up to $100 \%$ host country nationals (Henley, 2006). Additionally, some member schools are not for profit institutions, while some are proprietary. As such, the governance models range from externally managed to board governed, with multiple differences in board composition and mandate. Still other schools operate as transplanted national schools, offering national programs to primarily 
expatriates from their own country. American International schools are one such group of schools, many of whom "receive financial aid and support from the U.S. Department of State under a program sponsored by the Office of Overseas Schools" (Gillies, 2001, p. 396) Thus, the profile of an international school is anything but easily defined.

This independent quality of international schools means that collecting comprehensive and accurate data on issues such as teacher turnover has proven very difficult. The ECIS and CIS (E/CIS) organizations have for some years cooperated in the administration of an annual survey of their member schools, which offers useful data on a number of fronts. However, while the data these surveys offer regarding teachers leaving schools paint a rudimentary picture of the degree of turnover, they do not offer specific enough information to insightfully analyze the phenomenon of teacher turnover in international schools. Nonetheless, in the survey conducted for the 2005-2006 school year, among the 270 schools who responded to this portion of the questionnaire there were 3193 teachers who left from the total population of 22098 (Henley, 2006). That represents a turnover rate of $14.4 \%$, a figure which places at least these international schools close to the troublesome percentages cited for U.S. schools.

\section{Summary of the Problem}

While there are substantive differences between the U.S. schools that have been studied in depth regarding the impact of teacher turnover and the international schools that will be the subject of this study, there remain strong parallels that render the U.S. studies very applicable. First, schools the world over are entrusted with a similar mandate, the foremost of which is academic achievement. On this front, a number of 
findings underscore the importance of the issue at hand. First, it is clear that student achievement gains reside at the teacher level (Ross, Stringfield, Sanders, \& Wright, 2003). Given the plethora of school improvement initiatives, it is critically important to acknowledge that one of the most, if not the most important variable for student achievement is the teacher. In and of itself, that fact is neither surprising nor sufficient to justify a study of teacher turnover. However, in a study of New York City public schools it was found that teacher turnover was negatively correlated to school performance at all levels (Vidal \& Xu, 1992). Elfers et al (2006) found that teacher turnover had the greatest potential for causing disruption in students' learning opportunities. Hanushek et al (2001) revealed that the schools that had the greatest difficulty retaining teachers were those serving academically disadvantaged students. Other studies pointed to the consistent phenomenon of teachers moving from low performing to higher performing schools (Falch \& Ronning, 2005; Falch \& Strom, 2002; E. Hanushek, 2004; Ritchie, 2004; Scafidi, Sjoquist, \& Stinebrickner). A related finding was that teachers in U.S. schools tend to move from low socio-economic status (SES) schools to higher SES schools (Krei, 2000). While none of the above studies were empirical studies that allowed for cause-effect conclusions, it is inescapable that there is a connection between teacher turnover and student achievement.

Another parallel between U.S. schools and their international counterparts is that the institutional cost exacted by high teacher turnover exists regardless of the school's location. That cost can be broken down into two subsets: financial and social capital. Norton (1999) calculated that replacing a worker typically costs $25 \%$ of each person's salary. In the No Dream Denied Summary Report (Hunt \& Carroll, 2003), the cost of 
annual, statewide teacher turnover in Texas alone was cited to be "conservatively set at $\$ 329$ million" (p. 13) The same report itemized one serious drain on financial resources as being the need for professional development to equip teachers who are new in schools to be able to perform well in those schools. More difficult to measure is the value of the time spent by administrators in coping with the constant flow of teachers into and out of their schools.

In addition to the financial drain on schools, high teacher turnover is a drain on the social capital of the school. When teachers leave a school, they remove themselves from the complex and intricate social fabric of that institution. All the experience and expertise acquired while in that school leaves with the person (Johnson \& Birkeland, 2003), and the hole that is left may or may not be filled with someone of equal experience and expertise. In fact, studies show that in many cases he or she is not (DarlingHammond, 2003). Additionally, the cohesion, coherence and continuity associated with successful organizations is seriously impacted (Darling-Hammond, 2003; Ingersoll, 2001). "High rates of teacher turnover are of concern not only because they may be an outcome indicating underlying problems in how well schools function, but also because they can be disruptive, in and of themselves, for the quality of school community and performance" (Ingersoll, 2001, p. 505). While it is difficult to determine whether problematic schools are caused by or provoke teacher turnover, it is clear that high teacher turnover takes a serious toll on the human side of a school's operations. 
The Purpose of the Study

The purpose of this study is to explore variables that have influenced teachers in international schools to leave the school at the end of their first contract with that school. Using a mixed method quantitative and qualitative study design, collecting and analyzing data by way of teacher responses to a questionnaire, the study sheds light on why teachers choose to leave schools after a relatively short period of time. A teacher's decision to leave an international school is the function of a complex blend of variables, and the best way to obtain insight into how such a decision is made is to ask teachers directly. Specifically, it is the goal of this researcher to understand which of the most influential variables are within the scope of control of a school administrator. In examining teacher motivation underlying the departure, it is hoped that intervention strategies will be made possible (Kersaint, Lewis, Potter, \& Meisels, 2007).

\section{Main Research Question}

This study will identify several key variables that might factor into a teacher's decision to leave an international school. It will seek to identify which of those variables seem to have had the greatest impact on the subjects of the study. In doing so, this study will answer the following question:

What variables do international school teachers who leave at the end of a first contract with a school describe as influential in their decision to leave that school? 


\section{Subsidiary Questions}

a.) Are there differences in identified key causal factors by associative school characteristics?

b. Are there differences in identified key causal factors by associative teacher characteristics?

\section{Hypothesis}

A detailed treatment of the methodology of data collection and analysis will be presented in a following chapter. For now, it should be noted that the null hypothesis in this study is that there will be no significant difference in the mean rank values of causal factor scores by associative factor populations. The alternative hypothesis is that at least two of the associative factor populations will differ on one or more of the causal factor mean rank scores. The level of significance is set at .05 , in keeping with accepted standards for social science research (Hinkle, Wiersma, \& Jurs, 2003).

\section{Significance of the Study}

This study is premised on the assumption that a stable teaching population is a key variable in establishing stability and continuity in schools (Ingersoll, 2001). This feature is particularly important in international schools, where the school often offers stability to highly mobile expatriate families and their children (Hardman, 2001). Relocated families look to the school for a sense of confidence that the experience they will have will be a positive one. Equally importantly, expatriate families who have been at a school for several years want to see a program that offers continuity and consistency, in which their children can experience steady academic and personal 
growth. Establishing and maintaining such a program in an international school is also premised on a stable teaching population (Hayden \& Thompson, 1998).

International school teachers and administrators alike recognize that stability in their teaching population is necessary for maximum effectiveness as a school. They also recognize that this means that when teachers only stay for the minimum single contract period, typically two years, stability in the school is eroded. Ironically, one study revealed that $52 \%$ of the participating teachers had never renewed a contract for more than two years. This discrepancy between beliefs and behaviors leads to the conceptual framework underlying this study. It has been modified only slightly from the framework adopted by Guarino, Santibanez and Daley (2006, p. 201) in their review of recent empirical literature. The concept underlying this study is that teacher turnover is a function of the relative attractiveness of staying at the school $\mathrm{v}$. leaving the school. Thus, if the overall perceived benefits of leaving the school outweigh the overall perceived benefits of staying at the school, the teacher will leave. That departure means that the school has lost the social capital represented by the teacher, and has incurred various costs in replacing the teacher. School administrators would do well to investigate why teachers see greater benefit to leaving than to staying.

One of the costs incurred by teacher departure is recruitment of replacement teachers, which has been called the most important task of an administrator (Skinner, 1998). It might also be said to be one of the most time-consuming. In addition to enhancing the stability and continuity of the school, reducing teacher turnover would also save administrators from inordinate time spent recruiting replacements. This 
study seeks to offer insight into how international school administrators can influence current teachers to renew their contracts rather than leave the school. While there is great diversity among international school teaching staff (Cambridge, 2002), and the context in which international schools operate is highly variable (Cambridge, 2002), it is the goal of this study to discern influential variables that are common among teachers' decisions to leave an international school at the end of their first contract with that school. A further breakdown of the causal factors that fall within the control of the school will offer insight into how international school administrators can lower teacher turnover in their schools. In helping administrators to understand why teachers leave their schools, it may equip them to reduce such departures, to the extent that it is desirable to do so in their schools.

One final reason for engaging in the proposed study is to create an opportunity for dialogue, both for teachers and administrators. While the study itself will collect data in an anonymous fashion, the very fact that teachers will be asked to share why they left a school may open a dialogue among teachers, and ideally between teachers and their administrators, to address issues of concern to both parties. Because a teacher's decision to stay at or leave an international school is complicated, highly personal and potentially very stressful (Powell, 2001), the reasons for a departure are often left unspoken. Doing so robs a school's administration from the opportunity for selfimprovement. It is the goal of this study to collect data that will offer teachers an opportunity to express their concerns, and administrators an opportunity to learn what those concerns are. While it might be argued that it is too late to change the school 
from which a teacher has already left, the next school he or she goes to may well be a better school for having learned from the results of this study.

\section{Limitations of the Study}

The following are identified as possible limitations of the study.

1. Because of the independent nature of international schools, there is no centralized database through which to track teachers after they leave an international school.

2. While this study will work closely with a recognized and reputable organization comprised of international schools, even doing so will not reach all existing international schools.

3. Soliciting participation from all teachers currently registered in the main placement database operated by the above-mentioned organization will only access data from teachers who are currently in the market for moving schools. Any teachers who have left teaching, or who are not registered in the main placement database of said organization will not have the opportunity to contribute to the data collection. While the purposeful sampling strategy employed in this study is a recognized and respected strategy (Patton, 2002; Punch, 1998), because it is not a randomized sample, findings will not be generalized to the population of all international teachers in all international schools.

4. The incentive for teachers to participate in the study may be perceived as

weak. Teachers will be asked to respond to a questionnaire regarding why they left a 
previous school, which may have been perceived as having little or no value in their current employment situation. Ironically, the issue may be perceived as most important to school administrators, but the data needs to come directly from teachers.

5. Survey research requires respondents to interpret the meaning of words, phrases and concepts before responding. It cannot be assumed that the researcher and the respondent have interpreted each prompt in a questionnaire in exactly the same fashion. Caution must be exercised in the interpretation of study findings that draw heavily on survey research.

6. Survey research also imposes the cultural constructs of the researcher onto respondents. A researcher cannot help but to create questions from his/her own worldview, which may not be the worldview of the respondent. This too must be considered in the interpretation of the study findings.

7. Closed-response survey questions may impose normalizing judgments onto respondents. For example, only offering the options of "married" and "single" on a questionnaire begs the question of what it means to be married, and disallows a respondent the opportunity to offer a preferred categorization, or an explanation of what it means to him/her to check off one or the other box. Nonetheless, the scope of this study does not allow for the exploration of all possible categorizations, and must proceed using certain categories employed in previous studies to disaggregate and examine the data.

8. The qualitative methodology of data collection and analysis is subject to the skill and bias of the researcher. 


\section{Delimitations of the Study}

1. There has been much debate in the literature about what it means to be called an international school (Hayden \& Thompson, 1998; McKenzie, 1998; Richards, 1998), with several criteria offered but none universally agreed upon. In keeping with the independent nature of school communities that call themselves international, even if there did exist a clear set of criteria, there does not exist one single organization through which membership around the world could be regulated and granted only to schools meeting said criteria. Thus, this researcher chose to bypass the contentious debate, and will consider any school who is a member or associate member of the CIS collection of schools as of June, 2007 to be deemed to be an international school, for the purpose of this study. Additionally, it is not a given that all schools about which teachers are commenting are in fact members of CIS. It is possible that a teacher registered in the CIS teacher placement database taught previously in an international school that was not a member of CIS. Because teachers do not always know the affiliations of the schools at which they teach, it is not feasible to ask that question of them on the survey instrument. Thus, the assumption will have to be made that such instances are negligible.

2. Teachers in these international schools are hired under a variety of contract conditions. In some schools, even expatriate teachers are hired under local contracts. While this study will include all expatriate teachers, regardless of the nature of their contract, the study will not include local teachers. The researcher does not seek to be discriminatory against local teachers, but feels that understanding why local teachers 
decide to leave a school is a much different study than understanding why expatriate teachers decide to leave a school.

\section{Assumptions of the Study}

At this point it is important to clarify certain assumptions made by the researcher. 1. Written feedback will be limited in volume. While each item in the final section of the questionnaire offers the opportunity to offer written feedback, because respondents typically seek to finish questionnaires as quickly as possible, it is unlikely that many will take time to write extensive responses.

2. Respondents will likely only add written comments on items that were highly influential in their decision to leave the school. Thus, the volume of qualitative data is expected to be such that the researcher will be able to process the written feedback without the assistance of a software program designed to classify extensive written data.

\section{Definition of Terms}

Teacher attrition - the loss of teachers from a school or school system because they have left teaching altogether.

Teacher mobility - the loss of teachers from a school or school system because they have left one school and moved to another school.

Teacher turnover - at the school level, the combined impact of teacher attrition and teacher mobility, calculated as a percentage of the total number of teachers at the school. Figures relating to teacher turnover are generally presented as a calculation of annual percentages. 
Expatriate - someone employed in a country other than that of which he or she is a citizen.

Local contract - a teacher's employment contract of which the overall compensation value is substantially less than an overseas contract (Richards, 1998, p. 178). Local contracts are most often, but not always, offered to locally recruited teachers.

Overseas contract - a teacher's employment contract of which the overall compensation value is substantially higher than a local contract (1998, p. 178). Overseas contracts are most often, but not always, offered to internationally recruited teachers.

Associative Factors - associative factors are those factors shown in the quantitative studies in the professional literature to have predictive associations with teacher turnover.

Causal Factors - causal factors are those factors which teachers have reported in qualitative studies in the professional literature to have influenced their decision to leave a school.

\section{Summary}

A moderate degree of turnover in any organization is generally deemed to be healthy (Ingersoll, 2001). However, the consensus in the literature suggests that teacher turnover percentages are currently in the unhealthy range, particularly in light of dwindling resources available to replace lost teachers (Guarino, Santibanez, \& Daley, 2006). In particular, international schools incur heavy costs for recruiting teachers, starting with but not limited to the travel associated with doing so (Skinner, 1998). In addition to hard currency costs, there are high institutional costs also associated with teacher turnover in 
international schools (Hayden \& Thompson, 1998). A starting point for addressing the issue of high teacher turnover in international schools is to identify the underlying reasons why teachers choose to leave schools at the end of their initial contract, rather than extend their stay. In particular, isolating the administratively mutable variables from administratively immutable variables will equip administrators to find ways to reduce teacher turnover in their schools. 


\section{CHAPTER II}

\section{REVIEW OF RELEVANT LITERATURE}

\section{Context}

Looming teacher shortages in the United States have been predicted by policymakers and researchers for many years now (Ingersoll, 2003), based on projections of increased student enrollment around the same time as the baby boomers in the teaching force reach retirement age (Ingersoll \& Smith, 2003). Nonetheless, while there are indeed teacher shortages in several specific states, and urban and rural areas in general (McCreight, 2000), current research seems to point to one variable in explaining the shortage. That phenomenon is teacher attrition, specifically the loss of teachers from the profession before retirement age. The most comprehensive data on this topic to date is that collected by the National Center for Education Statistics of the U.S. Department of Education. Called the Schools and Staffing Survey (SASS), four cycles of data collection have been completed: $1987-1988 ; 1990-1991 ; 1993-1994 ; 1999-2000$. Following each cycle, one year later the same schools are contacted for the purpose of administering a questionnaire to all teachers who moved from the school or left teaching. This process is called the Teacher Followup Survey (TFS). The data collected through this process have been widely used in studies attempting to understand teacher attrition and to promote its converse, teacher retention. In the 2003 Summary Report completed by the National Commission on Teaching and America's Future, the authors make the emphatic claim that "teacher retention has become a national crisis" (Hunt \& Carroll, p. 8). Thus, a substantial body of the literature on the topic is devoted to understanding teacher attrition from and retention in the overall field of teaching. 
As important as the above topic is, one subset of that topic also merits attention. That topic is teacher turnover, defined by this researcher in the previous chapter as the loss of teachers at the school level, whether through attrition from the field of teaching or mobility to another school. When a teacher leaves a school, whether his or her destination is another school or some other profession, the loss to the school remains the same (Ingersoll, 2001; Johnson \& Birkeland, 2003; Kersaint, Lewis, Potter, \& Meisels, 2007). Thus, while it is important for policy makers at the macro level to understand how teacher retention in the field of education can be improved, it is also important for administrators in schools to understand how retention at the school level can be improved.

While studies addressing this subtopic in the context of U.S. schools are growing in number, there remains a dearth of such studies from international schools. Thus, the review of literature relevant to this study will begin with the body of literature focusing on U.S. schools, will broaden from there to examine other national and multinational studies, and will conclude with the few studies that exist regarding teacher turnover in international schools. While the preferred source of the literature was refereed and peer reviewed journals, other reports have also been cited, to round out the context of the work in this field. Where appropriate, cautions have been issued about the findings offered in reports from other than peer reviewed journals.

Teacher attrition and teacher turnover in the United States

The most complete picture regarding teacher attrition and teacher turnover is that offered by the data collected in the SASS and TFS cycles. In examining these data, Ingersoll (2001) clarified an alarming trend over the four cycles of data collection. In the 
first two cycles of the SASS/TFS surveys, entrants to the teaching profession outnumbered leavers. Specifically, in the 1987-1988 cycle, there were 178,344 entrants and 172,645 leavers, including retirees. In the 1990-1991 cycle, there were 191,179 entrants and 173,994 leavers. However, in the subsequent two cycles of data collection that trend was reversed, and leavers began to outnumber entrants. In the 1993-1994 cycle, there were 192,550 entrants and 212,908 leavers, a gap of 20,358 . In the 1999 2000 cycle, there were 232,232 entrants and 287,370 leavers, a gap which rose dramatically to 55,138 . The trend line indicated by those numbers presents a troubling scenario for the welfare of the teaching profession.

Equally troublesome are the numbers specific to teacher turnover in the U.S. Again drawing from the four cycles of the SASS/TFS surveys, a calculation of the combined total hires from one year and total departures the subsequent year shows a similar trend (Ingersoll, 2001). In the $1987-1988$ cycle, that combined number is $28.6 \%$ of the total teaching force. In the subsequent three cycles, the percentages are $26.4 \%$, $27 \%$, and in the most recent cycle the percentage is $31.1 \%$. That means that between the 1999-2000 and 2000-2001 school years, almost a third of the entire teaching force in the United States was in transition (Kersaint, Lewis, Potter, \& Meisels, 2007).

The multiple costs of this phenomenon have been rightly deemed by the National Commission on Teaching and America's Future as unacceptable (Hunt \& Carroll, 2003, p. 13). While direct financial costs to school systems are difficult to measure, Norton asserted that in the U.S. workforce in general, the cost of replacing each worker is $25 \%$ of that person's salary $(1999$, p. 52). While that claim should be viewed with caution, as it was not substantiated by hard data, it is a number that was exceeded in a study conducted 
in Texas. The Texas Center for Educational Research conducted a study to ascertain the cost of teacher turnover in Texas (The cost of teacher turnover, 2000), in which they cited the $25 \%$ figure mentioned above, as well as a US Department of Labor estimate placing the cost of employee replacement at $33 \%$ of the new hire's salary $(2000$, p.2). Using five different industry cost models and the $15.5 \%$ teacher turnover rate in the state, the study estimated that the state of Texas was losing somewhere between $\$ 329$ million and $\$ 2.1$ billion per year to replace teachers leaving schools, depending on the cost model used (2000, p. 2). In the most recent treatment of this topic, the National Commission on Teaching and America's Future released in June of 2007 an 18 month study that calculated per teacher cost of turnover ranging from a low of $\$ 4,366$ to a high of $\$ 17,872$ (Nagel, 2007). The high figure came from the Chicago Public School district, whose total annual cost of teacher turnover was reported at $\$ 86$ million during the period of the study.

In addition to such hard currency costs, teacher turnover provokes a loss of productivity that is difficult to measure. Busy administrators are required to spend inordinate time in recruitment efforts, colleagues are asked to mentor new hires, and in general a great deal of time and energy is devoted to restoring the program to where it was before the turnover occurred (Darling-Hammond, 2003). Nowhere did this researcher discover any study of the lost productivity on the part of the departing teacher, although the US Department of Labor has devised a worksheet to determine the costs of employee turnover, on which it identifies a $50-75 \%$ productivity rate from the departing employee (Cost of Turnover Worksheet, 2007). 
Perhaps most salient to the measurement of the cost of teacher turnover is the impact on the school organization, and ultimately on student performance. In a widely cited study of teacher turnover from an organizational perspective, Ingersoll (2001) identifies that effective schools thrive on commitment and cohesion among their members. Schools with high turnover indicate that something about their social fabric is unhealthy. Thus, in his analysis, high teacher turnover is problematic not just because it causes disruption to the effectiveness of the organization, but because it indicates underlying issues that also impede overall success. Johnson \& Birkeland (2003) point to the network of relationships that are disrupted when a teacher leaves a school. DarlingHammond asserts that the high turnover in recent years has introduced "large concentrations of underprepared teachers" (2003, p. 8), taxing a school system's capacity to absorb the impact of this influx. Ross et al. (2003) identify that schools engaged in reform efforts are particularly vulnerable to high teacher mobility. Such factors inevitably impact student performance.

In fact, in one study conducted in New York City by The University of the State of New York, teacher mobility is shown to be weakly but significantly related to student performance (Vidal \& Xu, 1992). Prompted because New York City schools had higher than state averages on student and teacher mobility coupled with lower than state averages on student performance, the State Education Department commissioned a study to determine if the high mobility rates were correlated to low performance scores. All New York City public schools were included in the study, in which schools were categorized as having low teacher mobility (ranging from 0 to 10 percent), medium teacher mobility (ranging from 11 to 24 percent) or high teacher mobility (ranging from 
25 to 100 percent). Mean performances on various school outcome variables obtained from the State Department of Education were examined against the teacher mobility rates. As the teacher mobility rate went up, school performance went down.

Several cautions are in order regarding this study. First, although it is a robust study utilizing a strong data set, it was not published in a peer reviewed journal, and thus should be viewed with caution. Secondly, the study focused on both student mobility rates and teacher mobility rates, and controlled for such variables as attendance rate, poverty rate, limited English proficiency, and student and teacher minority composition. Thus, while both student and teacher mobility rates were significantly correlated to school performance, regression results indicated that the above variables all explained greater proportions of differences in school performance than mobility rates. Finally, correlation does not indicate causation. From this study it cannot be inferred that high mobility rates cause lower school performance, they are simply correlated to lower school performance.

Causes of teacher turnover in US schools

Given the costs of teacher turnover in so many areas, it is understandable that research has focused on the causes of this phenomenon. Ingersoll (2001) utilized SASS/TFS data to study teacher turnover from an organizational perspective. Specifically, he used the 1990-1991 SASS collection cycle and linked it to the 1991-1992 TFS collection cycle. This cycle of the TFS was comprised of 6,733 elementary and secondary teachers, of whom 3,343 were continuing teachers, 1,428 were migrating teachers and 1,962 were teachers leaving the profession. After summarizing the descriptive data showing the overall magnitude of teacher turnover, he conducted a 
multiple regression analysis of the effects of teacher characteristics, school characteristics and organizational characteristics on turnover. In the final stage of the study he examined the reasons teachers had offered in the survey for their departure.

The findings of this study indicated that school characteristics did indeed show significant differences in turnover rates. High poverty public schools had a higher turnover rate than affluent public schools. Private schools also had a higher turnover rate, particularly small private schools. Teacher characteristics as predictors of turnover included age and subject specialization. Younger teachers were 171 percent more likely to depart than middle-aged teachers. Special education teachers were more likely to depart than other subject areas. Finally, the main focus of this study was to examine organizational characteristics relative to teacher turnover. Findings on this topic revealed three characteristics to be significant. Turnover rates were distinctly lower in schools that; provided more administrative support to teachers, had lower levels of student discipline problems, and had higher levels of faculty decision-making influence and autonomy. In the final stage of analysis, teacher self-reported reasons for leaving were examined. Teacher responses were selected only from two types of schools: urban, high poverty schools and small private schools. After removing retirement and school staffing actions as reported reasons, the top two reasons reported by teachers for leaving the school were job dissatisfaction and the desire to pursue a better career or job opportunity. Job dissatisfaction was further broken down to identify sources, the most frequent of which were low salaries, poor support from the administration, student discipline problems and lack of teacher influence over decision-making. The consistency of these 
findings to those determined by the previous phase of the study lent confidence to both stages of the analysis.

Another study drawn from a large body of data (Harris \& Adams, 2007) differed slightly from the findings offered by Ingersoll. Harris and Adams used data from the 1992 - 2001 Current Population Survey (CPS) gathered monthly by the Census Bureau. This study only allowed for an examination of leavers, not movers, but compared attrition from teaching with attrition from three comparable professions: nursing, social work and accounting. This comparison found that attrition for teachers was higher than for nurses, but lower than both social workers and accountants. Findings from the study suggested that the primary difference among the professions was in the levels of early retirement, which were higher for teachers than the other professions.

In another robust study conducted using data from the 1999-2000 SASS, Ware and Kitsantas (2007) explored the connection between beliefs regarding teacher efficacy and commitment to remaining in the profession. Drawing from the questionnaires completed by 26,257 teachers and 6,711 principals, their study concluded that scales of teacher efficacy were found to be significant predictors of teacher professional commitment. Specifically, the study revealed that beliefs about the availability of administrative support and the capacity to influence decision making was significantly correlated to teacher commitment.

In a study from two large school districts in Florida, both leavers and stayers were surveyed for the reasons underlying their choice to either leave or stay (Kersaint, Lewis, Potter, \& Meisels, 2007). From resignations during the 2002-2003 and 2003-2004 school years, 901 leavers were interviewed. Their responses were compared to those from 898 
teachers who had continued to teach in the 2004-2005 school year from the same two districts. Consistent with previous studies, this one found that administrative support ranked highly in a teacher's decision to leave or stay, although it was more important among the group of leavers. Even more important to both groups was time with family and family responsibility, which again ranked more highly with leavers than with stayers. Another study conducted in Tennessee examined 37 elementary schools in Memphis in the 1995-1996 and 1996-1997 school years to determine the impact of school reform initiatives on teacher turnover (Ross, Stringfield, Sanders, \& Wright, 2003). The effectiveness and mobility of teachers at these schools were compared against the effectiveness and mobility of teachers at 63 other Memphis schools that were not involved in restructuring initiatives. While one particular restructuring design called Roots and Wings had higher teacher mobility rates associated with it, the overall results indicated that teacher mobility in Memphis did not seem to be strongly affected by school restructuring initiatives.

Another state based study examined teacher mobility and attrition in Wisconsin, focusing particularly on the impact of teacher salaries (Imazeki, 2002). Using an econometric approach based on a competing-risks duration model, the study was designed to determine the probability of a teacher leaving his or her district, particularly to move to a district with higher salaries. The study was based on data collected by the state from all beginning teachers in Wisconsin, and determined that teachers do respond to salary differences. Male teachers were shown to have a higher probability of moving in response to salaries than female teachers, but higher relative wages did increase the chances that even female teachers would exit the profession. Inter-district transfers were 
also shown to be effected by salary differences. These findings support other studies that correlate teacher turnover with dissatisfaction over wages.

Another study focusing on the impact of wages but conducted on a national level was that completed by Stinebrickner (2001). This study looked at the effects of both wages and personal factors in a teacher's decision to enter and leave the teaching profession. The study utilized data from The National Longitudinal Study of the High School Class of 1972 (NLS-72), which began with interviews of 22,652 students who were expected to graduate from high school in 1972 . These interviews were followed up by surveys administered in 1973,1974, 1976, 1979 and 1986 . The data were further narrowed to include information collected from 832 individuals who were certified teachers, and a final sample of 450 of the above individuals who became certified between 1975 and 1985, and whose personal information was complete enough to be used in the study. The personal factors determined regarding the teacher sample included age, marital status, children, and academic ability, as determined by SAT scores. The study findings suggested that it may be inaccurate to assume that teacher attrition is caused primarily by the attractiveness of other occupations. Particularly for women, marital status and number of children were more important predictors of exits from the teaching workforce. Individuals with higher academic ability, as measured by SAT scores, tended to exit the profession earlier than individuals with lower academic ability. It was posited that such individuals have greater opportunity to secure non-teaching employment that offers higher wages. Simulations conducted in the model designed by Stinebrickner suggested that the labor supply of then currently certified teachers would be 
responsive to wage increases, and would slow the rate at which teachers exit the profession (2001, p. 225).

This suggestion is supported by a long standing merit pay system in the Ladue School District of suburban St. Louis, Missouri (Morice \& Murray, 2003). In 2003 the district celebrated 50 years of using a teacher evaluation program that is tied to salary increases for strong performance. The system was devised in close consultation with teachers, and has been revised many times over its 50 year history. Salient to the topic at hand, in the years between 1993 and 2003, after removing retirements, the annual average rate of voluntary departure from the district was only 4.86 percent. The authors did clarify that there were other attractive features of this school district, such as low pupilteacher ratio, high per pupil expenditures, strong benefits, high performing students and a community that places a high value on education.

Washington state was the context for a study conducted by Elfers et al. (2006), in which two data sets were employed. The first was a comprehensive, longitudinal database taken from the Washington state personnel database spanning the school years from 1996-1997 to 2002-2003, inclusive. To supplement the information yielded by that database, the researchers also devised a Fast Response survey system to hear directly from teachers on a variety of subjects related to teacher turnover. Over the course of the 2003-2004 and 2004-2005 school years, six survey questionnaires were administered to approximately 400 teachers, roughly half of whom completed all six questionnaires. The study was designed to yield insight specifically into teachers who move from one school or district to another. The study showed that novice teachers (four years experience or less), changed schools at a higher rate than experienced teachers. After five years, only 
75 percent of novice teachers were still in the field of education. This finding was consistent with other studies that show that teachers newest to the profession are most at risk of leaving the profession (Ingersoll \& Smith, 2004). Also consistent with other studies, this one revealed negative correlations between retention and student poverty levels, student achievement levels, and percentage of African American students in the school. From the survey administered to teachers, factors most influential in decisions to stay or leave were cited as: the stability of the teaching assignment, the nature of colleagues, school location, personal or family reasons, school climate and support in dealing with parents and students.

A study conducted on teacher mobility in Texas drew from a database developed by the Texas Schools Project, compiled from multiple data sources to create a rich data set on all Texas public school teachers, students and schools for the years 1993 to 1996 (E. A. Hanushek, Kain, \& Rivkin, 2004). Findings from this comprehensive study are consistent with those cited herein. Specifically, teacher mobility is strongly related to student characteristics, whereby teacher turnover is highest in schools with low-income, low-performing and minority students. Teachers new to the career also experience the highest turnover. Salary was shown to exert only a modest impact on teacher turnover.

A study commissioned by the Ohio State Board of Education (Fleeter \& Driscoll, 2002) used data obtained from the Ohio Department of Education, the State Teachers Retirement System and the American Federation of Teachers to closely analyze Ohio's labor market for teachers. The report was not published in a peer reviewed journal, and thus its findings should be viewed with caution. Nonetheless, the findings related to teacher mobility were consistent with other, peer reviewed studies. Specifically, attrition 
is highest from teachers new to the field, teacher mobility rates vary depending on school characteristics, with large urban and poor rural districts experiencing the highest rates. Teacher salaries were shown to be low relative to both similar professions and historic comparisons to per-capita GDP. However, no aspect of the study analyzed the specific impact of salaries on mobility rates.

Addressing the issue of high attrition and mobility rates among entrants to the profession, Ingersoll and Smith (2004) examined the impact of teacher induction and mentoring programs. Using data from the SASS/TFS survey, and focusing primarily on data from the 1999-2000 SASS and 2000-2001 TFS, the study performed a series of regression analyses of the association between new teachers receiving induction or mentoring support and the likelihood of those teachers leaving at the end of their first year. After controlling for school background and teacher background characteristics, an association was discovered between induction support and likelihood of leaving. Specifically, the most effective features of support for new teachers were: having a mentor from the same subject area, being provided with common planning time, having scheduled meeting time to collaborate with other teachers, and being part of a network of teachers outside the school.

One study took an unusual approach to the question at hand by examining the impact of school facilities on teacher turnover (Buckley, Schneider, \& Shang, 2005). Factors considered in rating the quality of the school facility included indoor air quality, thermal comfort, classroom lighting and soundproofing to reduce ambient noise levels. Using data from a survey of teachers in Washington, D.C., comprised of 835 responses, the study found that even after controlling for the impact of other factors such as age, 
satisfaction with pay, satisfaction with parents, and length of service at the school, as the perceived quality of the school improved, the likelihood of teachers leaving decreased.

Another interesting approach to addressing the topic of teacher turnover was that taken by Johnson and Birkeland (2003), in which they sought to understand what voluntary movers were looking for when they left one school for another. Completed under the auspices of the Project on the Next Generation of Teachers, the study followed the career paths of 50 new teachers in Massachusetts over a period of four years. By the third year of the study, three teachers had been involuntarily transferred, eight had left teaching altogether, and three had left their public school to join a private school. Eight had voluntarily chosen to leave their school to move to another school. By means of personal interviews, the voluntary movers explained what they were searching for in their new school, presumably because it had not existed at their original school. The general categories of desired school characteristics revealed by these interviews were: reasonable teaching assignments and basic support, opportunities to learn and grow, and accessible, respectful leadership. While the findings of this study are rich in anecdotal narrative evidence, because of the limited number of participants caution should be exercised in generalizing any of the findings. Nonetheless, they do bear strong similarity to the findings of other studies cited in this review.

A similar approach was employed in a study conducted using North Carolina teachers (Williams, 2003), in that several teachers were interviewed to hear their thoughts regarding optimal school conditions that enhance retention. However, this study focused on 12 teachers each of whom had at least 15 years of classroom experience, and who had been recommended by their principals as being outstanding teachers. Because the study 
did not reveal the questions posed during the interview, much was left to the reader to imply regarding what prompts were offered to the interviewees. However, the synthesis of the interviews seemed to point to common teacher characteristics rather than school characteristics as explanation for why they had stayed in the profession, and many of them in their same schools. While most credited strong support from the principal, which is consistent with findings from other studies, the author of this study suggested that all 12 teachers had been able to satisfy strong personal needs for creativity and autonomy while cultivating meaningful relationships with colleagues and students. Aside from the implications for school principals, the interesting results from this study suggest that teacher attrition and mobility rates may be more closely connected to teacher characteristics than to school characteristics.

Finally, the meta-study conducted by Guarino et al. (2006) revealed a set of highly consistent findings regarding teacher attrition in the United States. Beginning from the premise that they would only include studies that were relevant, scholarly, empirical and of high quality, they sifted through almost 5,000 articles to arrive at 46 studies that were included in their review. Salient to the study at hand were the following findings (2006, pp. 200-201). Teacher characteristics of leavers included that they were: either at the beginning or the end of their career, predominantly white, of higher measured academic ability, female, and more likely to have taught math or science than any other subject. School characteristics from which teachers tended to leave were that they were urban public schools that had a high proportion of minority, low-income and low-performing students. Salaries were shown to be a factor in teacher retention, and were often cited as reasons for leaving the profession. The findings regarding the impact 
of induction and mentoring indicated that schools with those programs had lower turnover among beginning teachers, if the programs fostered collegial support. A related finding was that offering teachers the combination of autonomy along with administrative support was also associated with lower turnover rates.

Teacher turnover studies from other countries

While studies written in English on the subject of teacher turnover in countries other than the US are not numerous, there are several that offer insightful findings. One such study was conducted in the Gansu province of China (Sargent \& Hannum, 2005). Gansu province is in China's interior northwest and has a population of 25.62 million people, $76 \%$ of whom live in rural, high poverty areas (2005, p. 186). Using data collected in the Gansu Survey of Children and Families conducted in 2000, information was obtained from 100 village leaders, 128 principals, and 1003 teachers. Based on the conceptual framework that teachers who are satisfied in their work are less likely to leave the school, this study was designed as a case study to examine the associations between community, school, and individual teacher factors and teacher work satisfaction. Findings with regard to community factors indicated that after controlling for all other factors, a negative correlation was discovered to exist between economic development of the village and teacher satisfaction. Regarding school factors, teachers were found to be more satisfied in schools with more resources, where they were paid on time, where professional discussion and collaboration existed, and surprisingly, where the workload was the highest. Also surprising was the discovery of a negative relationship between teacher salaries and teacher satisfaction. Regarding teacher factors, the study found that younger, better educated teachers and male teachers were less satisfied. While this was a 
robust study, caution must be exercised in generalizing its findings, as teacher demographics in rural China have a much greater diversity than either American or international schools. The teachers in this study ranged from fully certified teachers to "daike" teachers, who have received no pre-service training (2005, p. 203). The authors of this study suggested that phenomenon as one reason for the counterintuitive findings regarding teacher salary and teacher workload associations with teacher satisfaction.

Another study examining the connection between teacher satisfaction and retention was based in England (Rhodes, Nevill, \& Allan, 2004). Focusing on a local education authority (LEA) in the West Midlands with a history of difficulty with teacher retention, a survey was issued to all faculty in the 118 schools in the LEA. While the study reported that 368 teachers responded, there was no indication of the total number of teachers in the LEA, making it impossible to calculate a response rate. The two factors shown to provoke the greatest job dissatisfaction were workload and time spent on administrative duties. Another two strong sources of dissatisfaction were initiative overload and pupil behavior.

A study based in New Zealand used data collected in the annual New Zealand Ministry of Education teacher mobility survey from 1999 (Ritchie, 2004). The study examined both teacher attrition and teacher migration (turnover), focusing mainly on the relationship between school SES and teacher movement. Using a school's Targeted Funding for Educational Attainment level (TFEA) as the measure of school SES, the study found that in general, teacher movers tend to move from low SES to higher SES schools. Consistent with other studies, in this one youngest teachers exhibited the highest average upwards movement. Upward movement in primary schools was also shown to 
be highest. The lowest average movement was among the oldest teachers in the lowest SES schools.

Two studies were discovered that examined the issue of teacher turnover in the country of Norway. The first study, conducted in 2002 (Falch \& Strom) under the auspices of the Norwegian Research Council, examined the influence of non-pecuniary factors on teacher turnover. Given the rigid pay structure that exists in Norway, the researchers in this study sought to understand what variables besides pay had an impact on teacher turnover. Using a complete matched individual teacher-school data set for all public school teachers in the country along with information from all public schools for the years between 1992/1993 and 1999/2000, the study included teacher turnover from all three categories; inter-district mobility, intra-district mobility, and mobility out of the school sector. Data collected from temporary teachers, teachers on short-term contracts and teachers over 60 years of age were not included. In this study, the term quit was used to indicate the decision to leave the school, regardless of whether it was mobility or attrition in nature. Findings in this study included; the highest propensity to quit was found among young teachers, teachers with more education, teachers at schools with high minority and special needs students, male teachers, and teachers at schools that included non-certified faculty. School size and quit propensity was found to have a non-linear relationship, with the lowest quit propensity in schools with a population of 370 students and the highest quit propensity in the smallest and largest schools. The only finding in this study that ran counter to other studies was the higher propensity of men than women to quit. The explanation that was offered referred to generous support offered to working 
mothers in Scandinavian countries, making it much more feasible for working mothers to continue employment in Norway than in the U.S.

The second Norwegian study was similarly rich in its data set, accessing several government sponsored data sources capable of profiling all Norwegian public school teachers in all Norwegian public schools (Falch \& Ronning, 2005). Because this study focused on the impact of student achievement on teacher turnover, utilizing achievement data comprised of $10^{\text {th }}$ grade exam results for the school years 1999-2000 to 2001-2002, only teachers from schools that included a secondary program were included in the study. In this study, as in the previously cited study based in Norway, the term quit is used to indicate departure from a school, whether from mobility or attrition. Consistent with all the studies cited in this chapter, this study also found that teachers tend to leave schools with low student performance. On the mobility front, teachers who leave such schools move to schools with higher student academic achievement. The findings of both studies based in Norway should be treated with caution, as they were not published in peer reviewed journals.

In a comparative study involving primary teachers in England and Finland, the governments of both countries cooperated to compare how two very different approaches to promoting teacher professionalism was impacting teacher retention (Webb et al., 2004). Called the York-Jyväskylä Teacher Professionalism project, it was designed to compare the impact of the centrist approach to reform taken in England versus the autonomy offered to teachers in Finland. The York-Jyväskylä Teacher Professionalism project was a follow-up to a previous study called the York-Finnish Project (YFP), an ethnographic study of six primary schools in each country during the 1994-1995 school 
year. The York-Jyväskylä Teacher Professionalism project re-interviewed all teachers who in 2001 were still in their 1994-1995 school, as well as a number of teachers who had left their 1994-1995 school. This offered a comparative sample of 24 English teachers and 13 Finnish teachers. The study found that the strongest disincentive for continuing to teach in Finland was low pay, while in England it was an excessive workload. The second most important factor discouraging teachers from remaining in their schools was the same for both countries, a perceived deterioration in the behavior of students. The third most important factor was also consistent in both countries, a perceived decline in the public respect for teachers. The top incentive for remaining in the profession was common to both countries, that being the teacher characteristic of the love of working with children. While teacher autonomy ranked as a high incentive for remaining in the field for Finnish teachers, it was not cited by English teachers. Rather, English teachers cited a supportive network of relationships with colleagues, something also mentioned by several of the Finnish teachers interviewed.

The efforts of one other multi-national group merit mention in the review of relevant literature. The Organisation for Economic Co-operation and Development (OECD) consists of 30 member countries, all of whom are committed to democratic government and market-style economies, and who cooperate to research into a host of social and economic issues. In 2002 a two year OECD project entitled Teachers Matter: Attracting, Developing and Retaining Effective Teachers was launched in which 25 countries participated. The initial study conducted in 2002 (Santiago) focused on teacher supply and demand, and revealed several data gaps on the topic from participating countries. The only substantive studies that had been conducted at that time were based 
on US data (2002, p. 27), and have been cited previously in this literature review. While caution should be exercised in that they do not appear in peer reviewed journats, the findings of the final report published in 2005 (Teachers matter: Attracting, developing and retaining effective teachers) are consistent with those shown in the studies cited in this literature review. With respect to reasons for teacher turnover, those are namely that salary matters but is supplemented by working conditions, relationships with colleagues and students, support from administrators and opportunities for advancement. In that many of the studies cited originated from those cited in this literature review, such congruency is not surprising. What is surprising was the paucity of original research being conducted on the subject of teacher turnover in the member countries of the OECD. Teacher turnover studies from international schools

Thus it is that in finally turning to the literature on teacher turnover in international schools, the body of work is very limited indeed. As identified in the previous chapter, international schools are largely independent of any associations except those to whom they choose to belong. While it is not uncommon to experience cooperation among international schools for such purposes as professional development conferences, when it comes to a large scale analysis of challenges such as teacher turnover, there is little data to access that spans a broad cross section of schools. While references to problematic teacher turnover rates in international schools abound, studies examining factors associated with that phenomenon are rare. In fact, to date this researcher has only found one such study.

Using data collected by means of a questionnaire returned from 30 teachers from international schools in Indonesia, Tanzania, Egypt and Argentina, and supplemented by 
personal interviews with teachers from five international schools in Buenos Aires, the study sought to understand what factors influenced teachers to take up posts at international schools, and what factors might influence them to stay beyond the term of an initial contract (Hardman, 2001). From the outset it should be noted that caution must be exercised in viewing the results of this study. First, it did not appear in a peer reviewed journal, but rather an edited book. Second, the brevity and informality of the methodology employed, along with the very small (and ultimately unidentified) sample size, render the results impossible to consider as having much authority. Nonetheless, as the only actual study of causes of teacher turnover in international school, it is prudent to briefly examine Hardman's findings.

The reason identified by the greatest percentage of respondents for joining and remaining in an international school was professional advancement, with 88.5 percent citing it as an important factor. Three factors tied for second most cited, at 84.6 percent. Those factors were a happy working climate in the school, financial incentives, and a strong sense of job challenge. A happy working climate was further defined as feeling appreciated and respected by colleagues and administration, a sense of security, and strong relationships with colleagues and students (2001, p. 127). Hardman also probed the perceptions of the length of an ideal contract. While all teacher respondents agreed that a two year contract was not long enough, in that it compromised student learning, only 48 percent had ever renewed a contract beyond the initial two year offering.

A related observation that originated in Hardman's study and was elaborated on by Cambridge (2002) was a categorization of teachers in independent schools. The three categories were: childless career professionals, career professionals with families, and 
mavericks (2002, p. 162). As Cambridge expounded on, each category of teacher is motivated by different incentives to join and remain at an international school. While the theoretical framework offers potential, Cambridge only speculates on how teachers in each of the categories might be motivated to stay at or leave a school. The analysis is conspicuous by its absence in Hardman's study.

Far more robust is the work done by Hayden and Thompson (1998) and Hayden, Rancic and Thompson (2000) in exploring teacher and student perceptions on the nature of what is meant by international education, particularly in the context of international schools. While the focus of each of the above mentioned studies does not directly relate to the topic of teacher turnover in international schools, the two studies are of interest because of the demonstrated success of the chosen methodology. Given the scarcity of studies involving widespread data collection from international schools, it is important to see how the study of any topic relating to teacher perceptions in international schools can be effectively structured. In the study of teacher perceptions (1998), surveys were sent to teachers in a wide range of international schools around the world, with 226 questionnaires returned. Using a 5 point semantic differential scale, the mean and standard deviation were calculated to determine what is referred to as a "group average" (1998, p. 552). While such an analysis does not have the merit of breaking down responses by category of teacher, with a more fulsome collection of information from teachers, it could have done so. Similarly, the study involving student perceptions was conducted from data collected by questionnaire returned from 1263 students from 43 schools in 28 countries. The 32 items in the survey were grouped into nine construct categories for purposes of analysis. Again, while the topic is not related to teacher 
turnover, the methodology of successful data collection from a similar pool of potential respondents offers useful insight.

While there are other references to teacher turnover in the literature on international schools, they are of limited value. For example, Powell (2001) discusses the various stresses that are exerted on teachers when they relocate to and/or from international schools. After more than 25 years living overseas, he offers observations drawn from literature on the subject blended with his personal observations. While it does not qualify as a study, it does profile the challenges that are encountered when teachers move to or from international schools, highlighting that their reasons for doing so are likely to be powerful and compelling.

Also on the topic of teacher relocation, Joslin (2002) examines the specific challenges of a UK teacher's first overseas assignment. It is not a study of the phenomenon, but rather it offers a conceptual model for identifying the transitional challenges that can affect the success of a teacher transitioning to an international school. Focusing on the characteristics of the school is reminiscent of Ingersoll's analysis of teacher turnover from an organizational perspective (2001). Where Joslin adds to the usefulness for this study is that she also introduces conditions of the host country, primarily focusing on cultural expectations. Any study of the reasons underlying teacher turnover in international schools must certainly offer teachers the opportunity to comment on the impact of the host country on their decision to leave a school.

Another article focusing on overseas schools looked specifically at American international schools (Gillies, 2001), and identified the quick turnover of personnel as a major problem for such schools. Summarizing the results of a handful of studies that 
profiled the characteristics of overseas teachers, Gillies cites several characteristics as leading to success in overseas schools: adaptability, flexibility and competence. Unsuccessful teachers were defined as rigid and escapist. While other studies link teacher characteristics to teacher turnover, Gillies does not explore that connection.

Finally, one study examined a related issue, turnover among international school heads (Hawley, 1994, 1995). Hawley's study examined publicly available data on the 251 international schools accredited by the US Department of Defense between the years of 1980 and 1990. Specifically, he examined the turnover rate of school heads in those schools, and found that the average tenure was 2.8 years among the 336 heads represented by those 251 schools over the decade of data collection. Eighty-three school heads responded to a survey question regarding why they left, and the most common response identified some dimension of school governance as the impetus to leave.

\section{Summary}

Teacher turnover has for some time been recognized as a troublesome cause of difficulty in staffing schools. Studies examining this phenomenon in the United States have offered significant insight into teacher characteristics of both movers and leavers, and characteristics of schools from which they leave and to which they move. The problem of teacher turnover is not limited to the United States, however. Attention is beginning to be paid to this issue in national studies from countries other than the US, with findings that appear to be consistent with those based on U.S. data. Equally serious and perhaps even more complicated than teacher turnover on the national level, but ironically less studied, is the problem of teacher turnover in international schools. What 
reasons will teachers from international schools offer for their choice to leave a school at the end of a first contract with that school? 


\section{CHAPTER III}

\section{METHODOLOGY}

\section{Subjects}

As the unit of analysis in this study will be the individual teacher, it is individual teachers who will have to provide the data which answer the research question. As identified in Chapter I, one of the challenges of conducting a study among international school teachers who have left their school is the virtual impossibility of tracking such teachers. Thus, it is important to secure a partnership with an organization that can facilitate access to a wide range of teachers who fit the criteria under study. The criteria defining suitable teacher participation are that: a. the teacher needs to have left an international school at the end of his/her first contract with that school at some point in his/her career, and b. the teacher needs to be an expatriate of the country in which that international school operated.

The organization selected by this researcher for such a partnership is the Council of International Schools (CIS). Comprised of roughly 500 member schools from every region of the world, and representing approximately 30,000 teachers, this organization has a culture of collaboration with other organizations in the pursuit of research. In particular, CIS works closely with a sister organization called the European Council of International Schools (ECIS). When these two organizations work together on an initiative, they are referred to as the E/CIS. While these two organizations cooperate with one another on a number of fronts, the most salient to this study is the administration of an annual survey collecting a variety of data from member schools. For this reason, the 
E/CIS organizations have established a culture of data gathering, allowing for a strong level of cooperation between CIS and the researcher.

Of particular interest to this researcher is the fact that CIS offers a teacher placement service for its member schools. The starting point for such a service is the establishment and maintenance of a database of teachers interested in being placed in CIS schools. Teachers seeking placement can register in this database at no cost, but they must qualify under the criteria set by CIS ("Council of International Schools - Teacher Recruitment Services webpage", 2007). Those criteria are:

- "All candidates are required to have current teaching certifications/qualifications, with the exception of the GMU FAST TRAIN students who may enter the date certificate will be awarded. In many cases this certification is needed to obtain a work permit.

- You will be required to submit copies of all teacher certificates and degrees that have been awarded.

- You will be required to supply three (confidential) educational and supervisory references, one of which must be from your current school director/ head teacher. References must be submitted on CIS reference forms or school headed stationery. It is important that these are signed and dated. They may be e-mailed as attachments or faxed.

- TEFL/ESL teachers must have a degree in education.

- Candidates should have a minimum of two years' recent full-time experience within their certified area teaching children between the ages of 3-18 years. (Grades K-12) 
- Candidates need to have specific experience teaching in one or more of the following: USA, UK National, Canadian, International Baccalaureate, Australian New Zealand curriculum.

- All teaching candidates must be fluent in the English language and have 2 years experience teaching in this language.

- All teaching candidates must be flexible and able to teach in all geographical regions of the world" ("Council of International Schools - Teacher Recruitment Services webpage", 2007)

This database is separated into two categories, active and main. Teachers in the active database are actively seeking placement, and teachers in the main database have lapsed from the active category, but remain in the database for a period of three years from when they first registered.

This study will solicit participation from the entire population of teachers in the CIS teacher placement main database. This population has been chosen as the target population to study because it is a self-selected group who either have moved schools recently or have the intention of moving soon. Because one major challenge of researchers seeking voluntary participation in completing survey questions is accessing a motivated and representative sample of participants, this group was seen as ideal for fitting both those categories. In April 2007, the main placement database was comprised of roughly 3000 teachers, representing $10 \%$ of the total teaching population of CIS member schools.

Unfortunately, data describing the demographic breakdown of CIS teachers is severely limited. The data that do exist are derived from the annual statistical survey 
conducted by E/CIS. Even these data only describe the demographics of teachers from schools that responded to the 2006 Statistical Survey. 257 CIS schools responded in that survey, representing 22,080 teachers. The demographic data collected from that survey identify numbers of full time teachers by gender, and numbers of part time teachers by gender. See Table 1 for a breakdown of these data. Also identified by these data are numbers of schools and numbers of teachers by region of the world. See Table 2 for that breakdown.

Table 1

CIS Teacher Demographics for Schools Responding to the 2006 Statistical Survey, Full Time v. Part Time by gender

$\begin{array}{lrrr} & \text { Female } & \text { Male } & \text { Total } \\ \text { Full time } & 13,140 & 6108 & 19,248 \\ \text { Part time } & 2179 & 653 & 2832 \\ \text { Total } & 15,319 & 6761 & 22,080 \\ \text { Percentages } & 69.4 & 30.6 & 100\end{array}$

Table 2

CIS Teacher Demographics for Schools Responding to the 2006 Statistical Survey,

Teacher numbers by region of the world

Geographical area

Participating

Teachers

Percentage of

Schools

Represented Total Teachers

Australasia 


$\begin{array}{lccc}\text { Central \& South America } & 13 & 1130 & 5.1 \\ \text { Far East } & 24 & 1781 & 8.1 \\ \text { Indian Subcont \& Central Asia } & 15 & 932 & 4.2 \\ \text { Middle East } & 31 & 3048 & 13.8 \\ \text { North \& Central Africa } & 13 & 658 & 3.0 \\ \text { North America } & 15 & 1228 & 5.1 \\ \text { Northern Europe } & 71 & 5209 & 23.6 \\ \text { Southern Africa } & 5 & 250 & 1.1 \\ \text { Southern Europe } & 38 & 3903 & 17.7 \\ \text { South East Asia } & 29 & 3406 & 15.4 \\ \text { Totals } & 257 & 22080 & 99.5\end{array}$

The demographic breakdown of teachers in the CIS main placement database was impossible to calculate in advance of administering the survey. Thus, questions on the survey will solicit sufficient information to be able to offer a comparison of the demographic breakdown between participants in the study and schools that responded to the 2006 Annual Statistical Survey.

Within the population of teachers in the main placement database, a further purposeful sampling will be sought, that being criterion sampling (Patton, 2002, p. 238). As referred to above, the criteria defining suitable teacher participation is that: a. the teacher needs to have left an international school at the end of his/her first contract with that school at some point in his/her career, and b. the teacher needs to be an expatriate of the country in which that international school operated. These criteria relate directly to the main research question seeking insight into why expatriate teachers leave a school at 
the end of their first contract with that school. Only teachers fitting those criteria can provide the data that will answer the research question.

This study is modeled as a mixed method design, combining quantitative data generated by the Likert scale questionnaire responses and qualitative data generated by the open-ended questionnaire responses. While qualitative study designs often seek depth $v$. breadth of data, that need not always be the case (Patton, 2002). In this case, the research question is best answered by as broad a collection of responses as possible. While the study findings will not be generalized to all expatriate teachers in all international schools, the breadth of the sample combined with the purposefulness of the sample will allow for the collection of meaningful data leading to meaningful answers to the research questions.

Similar to the above point, the "knowledge payoff" (Punch, 1998, p. 245) will be highest with a data set collected from the purposeful sample of participants chosen. Because the data will be collected from the very pool of teachers seeking employment in international schools, the answers provided to the research questions will be of ultimate usefulness to the administrators who manage those schools. Any administrator seeking to address the issue of teacher turnover in her/his school will benefit from the answers provided by the sample of teachers selected for this study.

Research Procedure

Data collection

Permission has been confirmed from the executive officer of the CIS Teacher Placement Service to invite all teachers registered in their main placement database to participate in a survey regarding teacher turnover. See Appendix A for the letter of 
invitation. The letter will be sent via email, and as a stand-alone piece of communication. It will not be tied to the teacher's registration in the teacher placement service, and it clearly explains that participation in the survey is voluntary, anonymous and has neither anticipated risks for involvement nor repercussions for non-involvement. The letter explains the nature and purpose of the research study, the identity and affiliation of the researcher, and outlines the criteria necessary for participation. Included in the letter is a link to the questionnaire itself and consent to participate will be considered to be given by virtue of the invited participant accessing and completing the online survey.

Instrument

The survey instrument itself (Appendix B) is a questionnaire comprised of 22 questions, 20 of which are combined closed-set response and optional open-ended response, and two of which are open-ended response questions. The questionnaire was built following a careful analysis of the literature regarding teacher turnover. From that analysis, two construct categories of Associative Factors and Causal Factors were used to create the three sections of the questionnaire: Teacher Characteristics, School Characteristics and Reasons for Leaving. See the next section, Data Analysis, for a detailed explanation of the construct categories. Within each section, questions were built to solicit information necessary to identify the key Associative and Causal Factors for each respondent. Table 3 identifies the breakdown of each question item and the factor it helps define.

As suggested by Leedy and Ormrod (2005), the questionnaire was shared with a group of five colleagues, each of whom had specific expertise to offer in scrutinizing the survey instrument. One was chosen because he has been an international school principal 
for over 25 years, in five different schools and on two continents. Another was selected because he occupies a research position in a university in the $\mathrm{UK}$, and has published extensively on the topic of this study. The third member was chosen because she is employed to assist in data collection as a consultant by the international organization cited in this study, CIS. The fourth member is a veteran principal who has been a school head in both the U.K. and internationally. The final member of this jury of experts combines the skill sets of research methodology and international school leadership. A draft of the questionnaire was sent to each member of the jury, with a request to scrutinize it carefully and offer feedback on seven different aspects identified by the researcher, and any other features they noticed. Following receipt of that feedback, the researcher and his advisor amended the questionnaire as deemed necessary. In that fashion the survey instrument was tested and approved for face and content validity. The use of a jury of experts stands in place of piloting the survey with potential respondents (Creswell, 2007).

The questionnaire was composed in and electronically administered using software called ASSET (Academic Survey System and Evaluation Tool) and housed on the Seton Hall University website. The ASSET software was designed by a Seton Hall professor, and prior to its use in this study has been employed by numerous Seton Hall graduate students for the purpose of survey research. It is a robust and reliable vehicle for administering and collecting survey data, particularly well suited when participants are spread all over the world. The system relies entirely on electronic communication methods, and stores the data collected on a secure server at Seton Hall University. 


\section{Data Analysis}

Responses to the items in the survey were placed into the following categories.

Using the conceptual model of construct categories (Hayden, Rancic, \& Thompson, 2000) for analysis and comparisons, the two main constructs are:

Associative Factors

Self-reported Causal Factors

Associative factors are those factors shown in the quantitative studies in the professional literature to have predictive associations with teacher turnover. Causal factors are those factors which teachers have reported in qualitative studies in the professional literature to have influenced their decision to leave a school.

The two construct categories were further subdivided into the categories identified in the professional literature. Table 3 breaks down each construct into its component categories, identifies which survey item belongs in each category, and offers reference(s) to the literature from which the precedent has been drawn.

Table 3

Construct categories for survey data analysis

I. Associative Factors

A. School Characteristics

$\underline{\text { Sub-category }}$

Size of school

Perceived academic strength Item Number(s)

14

$15,17 \mathrm{G}$
Reference(s)

(Ingersoll, 2001)

(E. A. Hanushek, Kain, \& Rivkin, 2004)

(Elfers, Plecki, \& Knapp, 2006)

(Falch \& Ronning, 2005) 
Ownership structure

16

B. Teacher Characteristics

$\underline{\text { Sub-category }}$

Gender

Age

Marital status

Children

Experience

Subject area

Level of education
Item Number(s)

5

6

7

8

$1,2,3$

(E. A. Hanushek, Kain, \& Rivkin, 2004)

11

9,10

II. Self-Reported Causal Factors

A. School Characteristics
(Ingersoll, 2001; Santiago, 2002)

(Sargent \& Hannum, 2005)
(Imazeki, 2002)

(Ingersoll, 2001)

(Stinebrickner, 2001)

(Stinebrickner, 2001)

(Elfers, Plecki, \& Knapp, 2006)
Item Number(s)

$17 \mathrm{~A}, 17 \mathrm{~B}$,

17J, 17M $\underline{\text { Sub-category }}$

Administrative leadership

Working conditions
17C, 17E, 17F, (Webb et al., 2004)

17H, 17I (Elfers, Plecki, \& Knapp, 2006)

(Buckley, Schneider, \& Shang, 2005)

(Johnson \& Birkeland, 2003)

(Sargent \& Hannum, 2005) 
Compensation

Student discipline

Academic standards

B. Host Country Characteristics

C. Teacher Characteristics $\underline{\text { Sub-category }}$

Personal Factors

Professional advancement
$17 \mathrm{~K}$

$17 \mathrm{D}$

$17 \mathrm{G}$

$17 Q$

(Joslin, 2002)
$17 \mathrm{~L}, 17 \mathrm{O}$
(Imazeki, 2002; Ingersoll, 2001)

(Stinebrickner, 2001)

(Webb et al., 2004)

(Ingersoll, 2001)

(Rhodes, Nevill, \& Allan, 2004)

(Ingersoll, 2001)

(Webb et al., 2004) Item Number(s) Reference(s) 17N, 17P, 17R(Elfers, Plecki, \& Knapp, 2006)

(Ingersoll, 2001)

(Hardaman, 2001)

Item 16 does not appear in any of the professional literature, but that is likely because of the scarcity of data on and studies of international schools. This researcher chose to add it to the Associative Factors under the sub-category of School Characteristics.

\section{Additional Purposes of Sections I and II}

In addition to identifying the associative factors by which causal factors were analyzed, Sections I and II of the questionnaire also provide crucial data for commenting on the validity of the findings. The starting point is offered by items 12 and 13 , which are necessary to verify the suitability of each respondent. Since the study is designed to examine only expatriate teachers' perceptions, it is important to confirm that only expatriate teachers have submitted responses. Item 4 has no precedent in the professional 
literature, but was suggested by one of the jury of experts and deemed to be an important piece of information to help interpret findings. Item 5 offered the researcher the capacity to see how closely the gender breakdown of the respondents parallels the overall population of teachers in the CIS organization, as reflected by the 2006 Annual Statistical Survey data. The remaining data collected in Section I regarding teacher characteristics allowed the researcher to create a composite profile of the survey respondents. While there is no database of international school teacher characteristics against which to compare this profile, it remains important to have a sense of who has responded to the questionnaire. Doing so allowed the researcher to comment on the "population validity" of the respondents (Bracht \& Glass, as cited in Punch, 1998, p. 260). While caution will be exercised in generalizing findings from the study, being able to comment on this dimension of the source of the data enhanced the external validity of the survey results.

The questions in Section II regarding School Characteristics allowed the researcher to collect data that built a profile of the schools about which respondents were answering questions. As with teacher characteristics, this data allowed the researcher to compare certain profile characteristics of schools about which respondents were commenting with the overall profile of CIS schools, specifically geographic region and ownership structure. For all other school characteristics, it is equally important to be able to comment on the representative nature of the schools about which teachers are making assessments. Caution must be exercised in this area, however, for as mentioned previously, it is not a given that all schools about which teachers are responding are necessarily members of CIS. 


\section{Quantitative Analysis}

Each item in Section III of the questionnaire employing a Likert scale response generated a distribution of numerical responses. The quantitative dimension of this study was to analyze first the distribution of means among responses to the 18 statements that comprise the category of causal factors. Because these are ordinal data, a non-parametric test must be employed to compare the distribution of responses (Hinkle, Wiersma, \& Jurs, 2003). The test chosen for this element of the study is the Friedman One-Way ANOVA (George \& Mallery, 2003). This test is essentially a chi-square analysis on two or more distributions of ranked values

Subsequently each of the causal factors were compared by each of the associative factors, by breaking down the distribution of means for each causal factor by the groupings used for each associative factor. Again because of the need for a nonparametric measurement, the test used for this analysis was the Kruskal-Wallis One-Way Analysis of Variance, in that it allowed the distribution of means of each causal variable to be compared by $\mathrm{N}$ number of independent samples, or grouping variables (Hinkle, Wiersma, \& Jurs, 2003). In this way it was possible to determine if any of the different groupings of associative factors provoked significantly different responses on any of the causal factors. For example, male responses to salary as a causal factor were compared against female responses to salary as a causal factor to determine if there is a statistically significant difference on that associative factor. While both of these tests allow for the determination of statistically significant differences in the compared distributions, they do not allow for a post hoc test, such as Tukey's Honestly Significant Difference, to specify how each variable compares against the other variables. This part of the analysis 
is generated by a visual inspection of the mean ranks of each variable. While this reduces the scope of the study's findings, it honors the principles of quantitative data analysis.

$$
\text { Qualitative Analysis }
$$

The qualitative dimension of this study is premised on the value of multiple types of data (Patton, 2002, p. 556; Punch, 1998, p. 247). Findings from the quantitative data analysis will be compared against findings from the qualitative data analysis with a view to enhancing the validity of the overall findings of the study. As made clear by Patton (2002, p. 432), there is no universal formula for transforming qualitative data into findings. However, there are generally accepted approaches from which a researcher may choose the most suitable. This researcher used an "analytical framework" approach to organize and transform the data into findings (2002, p. 439). Specifically, the data were organized to describe the process of deciding to leave an international school at the end of a first contract. Data that revealed insight into what variables prompted expatriate teachers to make that decision were isolated, categorized and compared against the findings of the quantitative dimension of the study.

Written feedback was sorted into two types of data: 1.) Explanatory comments added in the Likert scale items, and 2.) Comments offered in the three final, open-ended questions of Section III. The first type of data have already been categorized, as each of the Likert scale items represents an element of a causal factor, as identified in Table 3. As these causal factors were drawn from the professional literature, they are firmly grounded in previous research. The purpose of examining these data was to add validity to the findings offered by the quantitative analysis, and possibly to offer more specific detail regarding each of the causal factors that proved to be instrumental in teachers' 
decisions to leave a school. These qualitative data were not further sorted by associative factors, but were considered as aggregate responses to each causal factor.

The collection and analysis of the second type of data marks a shift from deductive analysis to inductive analysis. Both the entire quantitative dimension of the study and the examination of the first type of qualitative data are deductive in nature, in that there exists a framework into which responses have been organized. This framework, previously identified as two construct categories and several subcategories, was generated from a careful review of the literature, and thus has the strength of previous research as its foundation. Nonetheless, this researcher wanted to leave open the possibility that causal factors other than those identified in Table 3 may be offered by survey respondents. It is for this reason that three open-ended items have been included as the conclusion to the questionnaire. After careful examination, responses to these three items were either added to the written feedback falling into the existing causal factors from Table 3, or they were considered as new causal factors. All new causal factors were inductively analyzed to determine if there was sufficient merit in adding further causal factors to the literature on why teachers leave schools. This required an examination of the frequency and strength of comments that seemed to point to a new causal factor, all of which were included in the researcher's analysis of this type of data. In this way he sought to examine the data "...for undiscovered patterns and emergent understandings..." (Patton, 2002, p. 454). A final analysis of this data was to offer a summary of the causal factors listed in item 19 (top three reasons for leaving), using the categories of Table 3 causal factors and any new causal factors that have been determined using the process defined above. 
It is important to make one final comment regarding the composition of questions in Section III. Of the 18 items combining Likert scale and open ended responses, 12 fall into the causal factor of School Characteristics. This apparently lopsided approach to data collection was carefully considered by the researcher. The starting point was the realization that the questionnaire needs to be brief and efficient in order to facilitate completion by as many invited participants as possible (Leedy \& Ormrod, 2005, p. 190). Thus, while it would have been interesting to collect more specific data regarding variables outside the control of the school, doing so would not have added to the usefulness of the study. The study was intended to offer insights into administratively mutable variables. The 12 statements about which respondents were to indicate a level of agreement were carefully constructed by combining the findings of a number of studies regarding why teachers choose to leave schools (Buckley, Schneider, \& Shang, 2005; Davis, 2002; Elfers, Plecki, \& Knapp, 2006; E. Hanushek, 2004; Ingersoll, 2001; Ingersoll \& Smith, 2004; Knapp, 2001; Norton, 1999; Rhodes, Nevill, \& Allan, 2004; Ross, Stringfield, Sanders, \& Wright, 2003; Scafidi, Sjoquist, \& Stinebrickner; Vidal \& $\mathrm{Xu}, 1992$ ). Thus, the content analysis is an extension of the existing body of literature regarding teacher turnover, but examined with data collected from expatriate international school teachers, a group who have not been studied yet. In this way it is hoped that the findings of this study will begin to address the need to understand a littlestudied phenomenon. 


\section{CHAPTER IV}

\section{FINDINGS}

\section{Overview}

This chapter presents the findings of the study exploring the phenomenon of expatriate teacher turnover in international schools. Specifically, as stated in the main research question, it seeks to identify which factors teachers name as most influential in their decision to leave an international school. Data collected by means of a survey will be examined with both quantitative and qualitative analysis methodologies, as identified in the previous chapter. Presentation of the findings will be structured around the subsidiary research questions separating associative factors into school characteristics and teacher characteristics. All eight causal factors identified in Table 3 will be examined by both types of associative factors to determine if there are significant differences among the causal factors by associative factors. This analysis will enable the researcher to decide whether to reject the null hypothesis that there is no significant difference. Before beginning the data analysis, it is important to describe the demographic breakdown of the participating teachers and the schools they represent, in order to confirm population validity (Bracht \& Glass, as cited in Punch, 1998, p. 260). These two general categories comprise the overall construct category of associative factors, also identified in Table 3.

\section{Teacher Characteristics}

An invitation to participate in the survey was sent in August of 2007 to the 3079 teachers then registered in the main placement database of the CIS teacher placement service. After a period of six weeks of opportunity to respond, a total of 435 participants 
had logged onto the survey, although only 286 had completed and submitted it. Of those 286 completed surveys, five had to be removed from the data set because they did not meet the criteria as outlined in the study. Three were not expatriates of the school's host country, one broke his/her contract with the school, and one revealed in his/her written responses that he/she had been at the school for eight years, making it highly improbable that he/she had left at the end of the first contract with that school.

Respondents' demographics compared against existing data

Table 4 identifies the gender breakdown of the 281 valid participants. Compared against the gender breakdown of the 2006 E/CIS Statistical Survey described in the previous chapter, which revealed a split of $69.4 \%$ female and $30.6 \%$ male, the gender breakdown of the respondents in this study is similar. No specific statistical analysis has been performed in comparing these two sets of data, and this evaluation is based solely on the judgment of the researcher. However, it is congruent with Thearle's (2000, p. 112) citation that over $60 \%$ of the workforce in international schools is female.

Table 4

Teacher Demographics for Survey Respondents by gender

\begin{tabular}{lccc} 
& Memale & Male & Total \\
\hline 169 & 112 & 281 \\
Percentages & 60.1 & 39.9 & 100 \\
\hline
\end{tabular}

As for the nationalities represented by the survey respondents, Table 5 reveals the breakdown represented by respondents in this study. The total number of nationalities represented by respondents exceeds total respondents by 10 , because 10 carried dual citizenship. For the purposes of this study, both nationalities were recorded. 
Table 5

Demographics for Nationalities Represented by Survey Respondents, by region of the world

Geographical area

Nationalities represented Percentage of by Respondents

42

14.4

Australasia

Central \& South America

1

0.3

Far East

0

0

Indian Subcont \& Central Asia

1

0.3

Middle East

0

0

North \& Central Africa

1

0.3

North America

120

41.2

Northern Europe

116

39.8

Southern Africa

3

3

2

0.7

Not identified

2

291$$
.3
$$

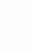

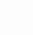

Totals

$\begin{array}{ll}2 & 0.7\end{array}$

Total Respondents

Unfortunately, as Canterford (2003) pointed out in his study, data regarding nationalities of teaching staff in international schools is rare. In fact he discovered only one data set, that collected by International Schools Services (ISS). Thus, it is only 
possible to compare the data from Table 5 against that collected by ISS, which does not use the same breakdown of geographical regions. Nonetheless, the phenomenon described by Hayden (2006) and alluded to by Garton (2000) is clearly the case for the participants in this study. For some time now international schools the world over have been staffed largely by teachers from the United States and the United Kingdom. In the data used by Canterford (2003), only three categories were presented by percentages of overall teachers: US and UK were combined into one category totaling $52 \%$, host country nationals were a second totaling $28 \%$, and all others were grouped together and called "other", totaling $20 \%$. Given that the current study ruled out host country nationals, when recalculated using only the two possible categories, the ISS data breaks down into US and UK totaling $72 \%$, and "other" totaling $28 \%$. Compared against the combined Table 5 total for North America and Northern Europe of $81 \%$, the demographic breakdown of nationalities for participants in this study seems to be similar to the ISS data.

\section{Composite profile of respondents}

The remaining data collected in Section I regarding teacher characteristics has equipped the researcher to create a composite profile of the survey respondents. Because of the paucity of such studies in international schools, it is not possible to reference these data against other data sets. Nonetheless, it remains important to understand the profile of the group of teachers who responded to this survey. All items of the questionnaire were to be answered with details from the year in which the respondent left the school about which he or she was responding. 
Table 6

Summary of Selected Teacher Characteristics

1. Total Years Teaching Experience

$\begin{array}{llllll}\text { Years } & 0 \text { to } 4 & 5 \text { to } 9 & 10 \text { to } 14 & 15 \text { to } 19 & 20+\end{array}$

$\begin{array}{llllll}\text { Respondents } & 83 & 72 & 47 & 32 & 51\end{array}$

2. Years at response school

$\begin{array}{lllll}\text { Years } & 1 & 2 & 3 & 4\end{array}$

$\begin{array}{lllll}\text { Respondents } & 55 & 154 & 34 & 40\end{array}$

3. Years at international schools

$\begin{array}{lllll}\text { Years } & 0 \text { to } 4 & 5 \text { to } 9 & 10 \text { to } 14 & 15 \text { to } 19\end{array}$

$\begin{array}{llllll}\text { Respondents } & 149 & 72 & 35 & 14 & 14\end{array}$

4. Year left response school

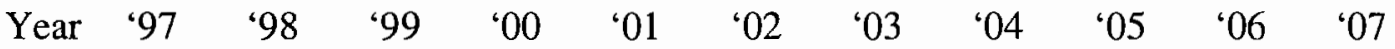

\begin{tabular}{lllllllllll} 
Rspds. 4 & 6 & 7 & 10 & 17 & 16 & 17 & 14 & 42 & 57 & 79 \\
\hline
\end{tabular}

5. Age when left response school

$\begin{array}{lllll}\text { Age } & \leq 29 & 30 \text { to } 39 & 40 \text { to } 49 & 50 \text { to } 59\end{array}$

6. Marital Status Single $=173$ Married $=113$

7. Number children when left response school

$\begin{array}{llllll}\text { Children } & 0 & 1 & 2 & 3 & 4\end{array}$

$\begin{array}{llllll}\text { Respondents } & 230 & 29 & 21 & 4 & 0\end{array}$


8. Education level when left response school

Bachelors Masters Specialist Doctorate or Professional Degree

$\begin{array}{llll}136 & 104 & 34 & 11\end{array}$

9. Main subject area of teaching

Elementary Generalist Math/Science Humanities

$\begin{array}{lll}81 & 54 & 45\end{array}$

Special Education $\quad$ English as Second Language Other Specialist

9 13 82

Note: As not all respondents completed all fields, totals are not consistent.

School Characteristics

In examining school characteristics represented by survey respondents, it is important to note that because schools were not identified, it is possible that multiple respondents described the same school. Nonetheless, it remains important to have a sense of how school characteristics for this study compare against E/CIS schools as shown in the 2006 survey data. Table 7 identifies the countries represented by the schools described by survey respondents. This data is presented by the regions of the world as determined by the E/CIS, in order to offer valid comparisons against E/CIS data. Table 2 in the previous chapter identifies the countries represented in the 2006 survey conducted by the E/CIS. 
Table 7

Demographics for Schools Represented by Survey Respondents, by region of the world

\begin{tabular}{lll}
\hline Geographical area & Schools represented & Percentage of \\
& by Respondents & Total Respondents \\
\hline Australasia & 0 & 0 \\
Central \& South America & 13 & 4.6 \\
Far East & 36 & 12.8 \\
Indian Subcont \& Central Asia & 7 & 2.5 \\
Middle East & 37 & 13.1 \\
North \& Central Africa & 8 & 2.8 \\
North America & 10 & 3.5 \\
Northern Europe & 85 & 30.2 \\
Southern Africa & 281 & 0.7 \\
Southern Europe & 40 & 14.2 \\
South East Asia & 42 & 99.6 \\
Not identified & & 14.9 \\
Totals & & 0.3 \\
\hline
\end{tabular}

A comparison of Table 2 with Table 7 reveals that the top five geographic areas are the same for both tables, and the order within that top five is close to identical. Table 8 shows the compared breakdown. 
Table 8

Comparison of E/CIS 2006 Survey Countries vs. Current Study, by Top Five Regions

\begin{tabular}{|c|c|c|c|}
\hline \multicolumn{2}{|l|}{$\mathrm{E} / \mathrm{CIS}$} & \multicolumn{2}{|l|}{ Current Study } \\
\hline Geographical area & Percentage & Geographical area & Percentage \\
\hline Northern Europe & 23.6 & Northern Europe & 30.2 \\
\hline Southern Europe & 17.7 & South East Asia & 14.9 \\
\hline South East Asia & 15.4 & Southern Europe & 14.2 \\
\hline Middle East & 13.8 & Middle East & 13.1 \\
\hline Far East & 8.1 & Far East & 12.8 \\
\hline Total percentage & 78.6 & & 85.2 \\
\hline
\end{tabular}

The only other school characteristic which can be compared against E/CIS data is school ownership. Table 9 compares the breakdown by both numbers and percentages, shown for both this study and E/CIS 2006 survey data. As can be readily observed, this study attracted a relatively high number of responses from teachers regarding privately owned schools. This point will be returned to in the data analysis section of this chapter. Table 9

Comparison of E/CIS 2006 School Ownership vs. Current Study

E/CIS

Ownership

Not for profit/trust 172

Privately owned $\quad 72$

Corporation owned 31
Number

Percentage

62.5

26.1

11.3
Current Study

Number

Percentage

138

49.1

124

44.1

16

5.7 


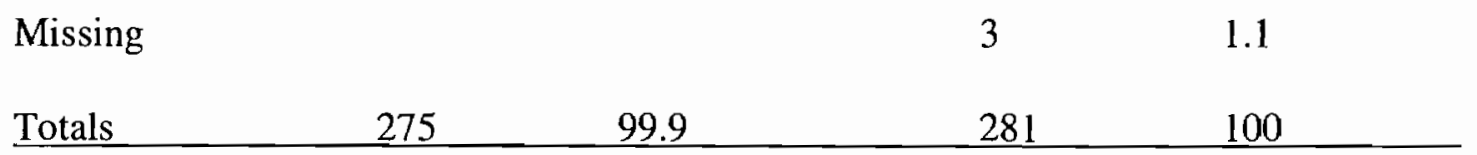

Composite profile of schools

As with many of the teacher characteristics, the remaining school characteristics do not have an existing set of data against which to be compared. They are presented here for the purpose of understanding the profile of the schools about which participants have responded. Table 10 indicates the range of programs offered at respondents' schools. As some schools offer more than one program, the total number of programs offered does not equal the total number of respondent schools. Schools offering a curriculum originating from a specific country were predominantly UK and USA based, but there were a small number of other countries represented as well. Figure 1 identifies school size.

Table 10

Programs offered in respondents' schools

Program

Cambridge International Examinations (CIE)

Advanced Placement (AP)

IB Primary Years Programme (PYP)

IB Middle Years Programme (MYP)

IB Diploma Programme (DP)
Number of respondent schools

50

50

98

79

166

National Curriculum 110 


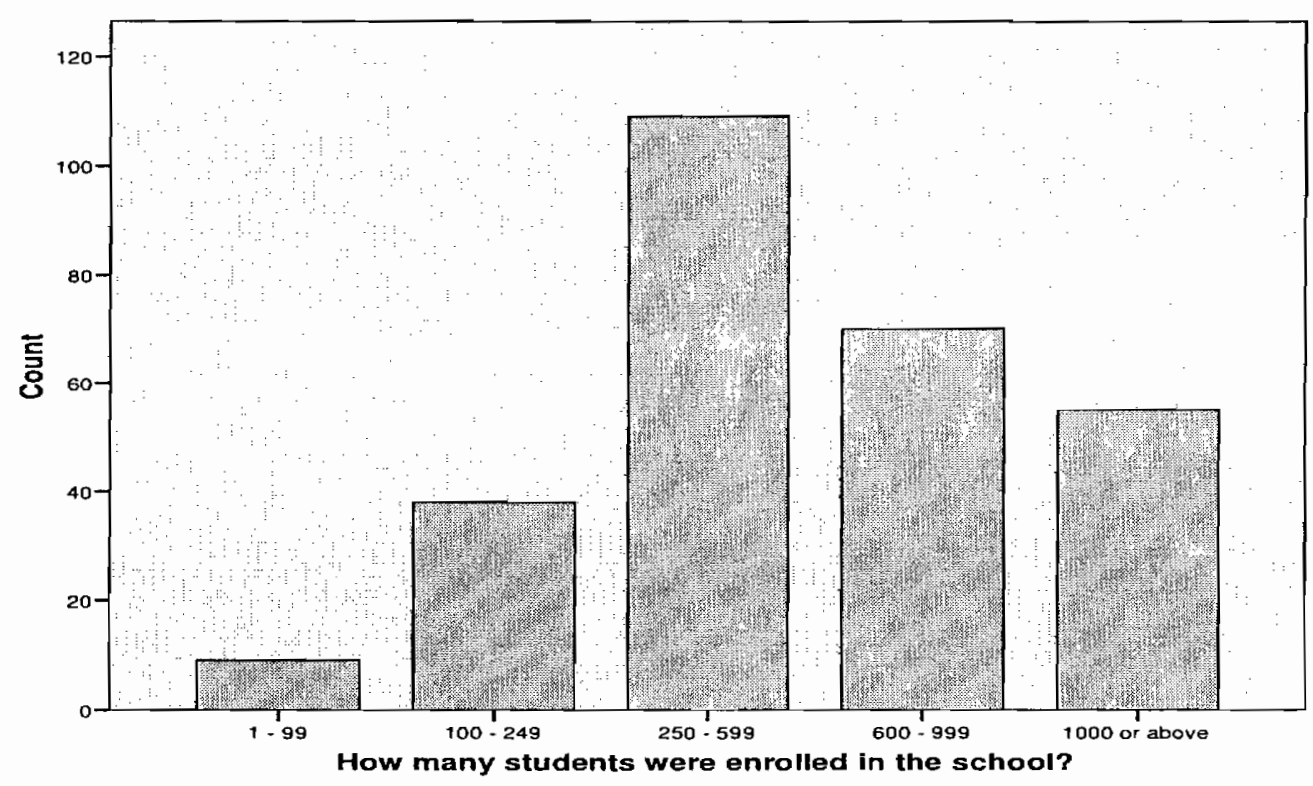

Figure 1. School size.

Data Analysis

Before launching into the combined quantitative and qualitative analysis of data, it is appropriate to offer some comments and caveats. The profiles of teachers and the schools about which they responded as shown above fall into two categories; that which can be referenced against existing data sets, and that which has no reference point. Any characteristics that have reference points seem to indicate a reasonable similarity in the breakdowns of both teacher and school characteristics with the existing data. Perhaps the most striking difference appears in the breakdown of school ownership. This study attracted a considerably higher percentage of responses regarding privately owned schools than the breakdown in the E/CIS 2006 survey data would have suggested. As will be seen very shortly, this phenomenon may be connected with a strong perception from respondents regarding the impact of school ownership on operational procedures. 
This possible response bias is one factor indicating the need for caution in generalizing the findings of this study.

Another element regarding the data collection bearing commentary is the response rate for the survey. As identified by Punch (1998), excessively low response rates are problematic because they increase the chances of bias in the data. It is noteworthy that he does not identify what constitutes an unacceptably low response rate. Clearly a simple percentage is neither a guarantee of meaningful data nor cause for dismissal of a study's findings. Each study must examine the context of the data collection and determine the extent to which findings are meaningful. Ultimately this analysis must address the question of bias in the data.

Calculated in the most basic manner, the response rate for this study is indeed very low. Of the 3079 members on the CIS main teacher placement database, 281 valid responses were submitted, for a response rate of $9.1 \%$. However, there are several mitigating factors that must be included in the presentation of this percentage. First of all, mass email transmissions seldom reach $100 \%$ of the intended recipients. That was indeed the case in the issuance of the invitation to participate in this study. Unfortunately, as the entire process was managed by a third party as identified in the previous chapter, the researcher did not have access to the number of bounce backs, or failed transmissions. The researcher must take full responsibility for this omission in the data collection, as he did not ask for this to be recorded in advance of the email being sent. In an email exchange with the CIS staff member responsible for the sending of the questionnaire several weeks into the data collection, it was discovered that the record of failed transmissions had been deleted, as it required memory capacity in said CIS staff 
member's email inbox. Nonetheless, he did confirm that there had been a sizable number of invitations that did not reach the intended recipients. Additionally, it was felt by a senior CIS executive that it was not possible to send any further email invitations as reminders, as it posed a drain on the limited time of CIS personnel. Thus, the actual response rate is already higher than indicated by $9.1 \%$, but how much higher is impossible to determine. It should be noted that the researcher remains deeply grateful to the CIS organization for the support offered, and understands the decision regarding sending further emails.

A second aspect is that considerably more than 281 people actually responded to the invitation by logging onto the online questionnaire. In total, 435 separate log-ins were recorded by ASSET, 286 of which were completed and submitted. Of those 286 , five had to be eliminated because they did not fit the parameters of the study. In considering why so many potential participants did not complete and submit the survey, two possibilities emerge. One is simply that the length of the survey discouraged respondents from completing it. Survey research must strike a fine balance between collecting as much information as possible, yet not scaring away potential participants. It may be that this questionnaire was simply too long for some potential participants. A second possibility is that participants did not read the invitation carefully enough to realize that the criteria for participation included only expatriate teachers, as defined in this study. This realization may have dawned as they reached the part of the questionnaire where they were asked, in direct succession, their country(ies) of citizenship and the country in which the school they were describing was located. Unfortunately, ASSET does not allow for the examination of incomplete questionnaires. 
Thus, no further analysis of this phenomenon is possible. It should be noted that the researcher did receive several emails from individuals who would have participated, but did not fit the criteria. One individual had even completed and submitted the questionnaire before realizing she did not fit the criteria, and wrote to request that her input be removed, which of course it was.

One final consideration is the precedent for similar studies in the literature. While there are not many such studies that have been conducted measuring perceptions of international school teachers, they are not without any precedent. Specifically, in a 1998 study of teacher perceptions in international schools (Hayden \& Thompson, 1998), questionnaires were sent to teachers in a wide range of international schools around the world. In that study, 226 questionnaires were returned. As no response rate was calculated, it was likely impossible to ascertain how many teachers actually received the questionnaire, not entirely unlike the dilemma in this study. A subsequent analysis of data collected via that survey was also published two years later (Hayden, Rancic, \& Thompson, 2000).

Ultimately, the question of bias in the findings of any study must be judged by all readers of the study. Bias is ever present, and must be factored into the results of any study. It is for that reason that careful attention must be paid to the preceding presentation of both teacher and school characteristics. Given the combined profiles of teachers and the schools about which they have responded, it is the conviction of this researcher that enough information has been presented for a thoughtful analysis on the part of any consumer of this study's findings. That notwithstanding, this researcher offers the caveat that caution should be exercised in the use of the findings from this 
study. While the data do yield interesting findings, those findings can only be ascribed to the group of 281 teachers who fit the parameters of the study and responded to the invitation to participate. Each reader should consider their own application of the findings which will now be presented.

\section{Quantitative analysis}

Having examined the associative factors by which causal factors will be analyzed, it is now time to look closely at the data collected regarding the construct category of causal factors. These data in their quantitative form were collected by means of the 18 statements that comprised item 17 of the questionnaire. See Appendix B for the survey instrument. Each statement identified a causal factor and asked participants to rate their level of agreement with the statement, using a 5-point Likert scale response. Table 11 identifies the simple descriptive statistics for each of these statements. The values assigned to the Likert scale responses were 1 for Strongly Disagree ranging to 5 for Strongly Agree. Thus those factors with the highest means were viewed by participants as having the most influence on their decision to leave the school. This data offers the starting point of the answer to the main research question. Figure 2 offers a visual comparison of the mean scores for each of the 18 statements. 
Table 11

Descriptive statistics for 18 Likert scale items comprising causal factors

Descriptive Statistics for Causal Factors

\begin{tabular}{|c|c|c|c|c|c|}
\hline & $\mathrm{N}$ & Mean & Std. Deviation & Minimum & Maximum \\
\hline $\begin{array}{l}\text { A. The level of support from } \\
\text { the principal and senior } \\
\text { management at the school } \\
\text { was influential in my } \\
\text { decision to leave the school. }\end{array}$ & 262 & 3.5611 & 1.47589 & 1.00 & 5.00 \\
\hline $\begin{array}{l}\text { B. The quality of the } \\
\text { induction program was } \\
\text { influential in my decision to } \\
\text { leave the school. }\end{array}$ & 262 & 2.4198 & 1.25612 & 1.00 & 5.00 \\
\hline $\begin{array}{l}\text { C. Resource support at the } \\
\text { school (technological, print } \\
\text { or otherwise) was influential } \\
\text { in my decision to leave the } \\
\text { school. }\end{array}$ & 262 & 2.7710 & 1.37334 & 1.00 & 5.00 \\
\hline $\begin{array}{l}\text { D. Student behavior at the } \\
\text { school was influential in my } \\
\text { decision to leave the school. }\end{array}$ & 262 & 1.9618 & 1.26191 & 1.00 & 5.00 \\
\hline $\begin{array}{l}\text { E. Parental support of } \\
\text { teachers was influential in } \\
\text { my decision to leave the } \\
\text { school. }\end{array}$ & 262 & 2.1450 & 1.17524 & 1.00 & 5.00 \\
\hline $\begin{array}{l}\text { F. The quality of the school } \\
\text { facility was influential in my } \\
\text { decision to leave the school. }\end{array}$ & 262 & 2.5763 & 1.34189 & 1.00 & 5.00 \\
\hline $\begin{array}{l}\text { G. The academic standards } \\
\text { of the school were influential } \\
\text { in my decision to leave the } \\
\text { school. }\end{array}$ & 262 & 2.4427 & 1.31982 & 1.00 & 5.00 \\
\hline $\begin{array}{l}\text { H. The stability of my } \\
\text { teaching assignment at the } \\
\text { school was influential in my } \\
\text { decision to leave the school. }\end{array}$ & 262 & 2.3511 & 1.40565 & 1.00 & 5.00 \\
\hline $\begin{array}{l}\text { I. Expectations regarding } \\
\text { teacher workload were } \\
\text { influential in my decision to } \\
\text { leave the school. }\end{array}$ & 262 & 2.6794 & 1.39659 & 1.00 & 5.00 \\
\hline
\end{tabular}


J. Communication between senior management and faculty at the school was influential in my decision to leave the school.

$K$. The overall compensation package offered to me was influential in my decision to leave the 262 3.1527 school.

\section{Opportunities for} leadership at the school were influential in my decision to leave the school.

$M$. Teacher involvement in decision making at the school was influential in my decision to leave the school.

N. A mismatch between my expectations regarding the school and/or my role and the reality when $I$ arrived was influential in my

decision to leave the school.

\section{O. Opportunities for} professional advancement elsewhere were influential in my decision to leave the school.

\section{P. Personal circumstances} were influential in my

decision to leave the school.

Q. Living conditions in the host country were influential in my decision to leave the school.

R. The quality of my personal life while at the school was influential in my decision to leave the school. 


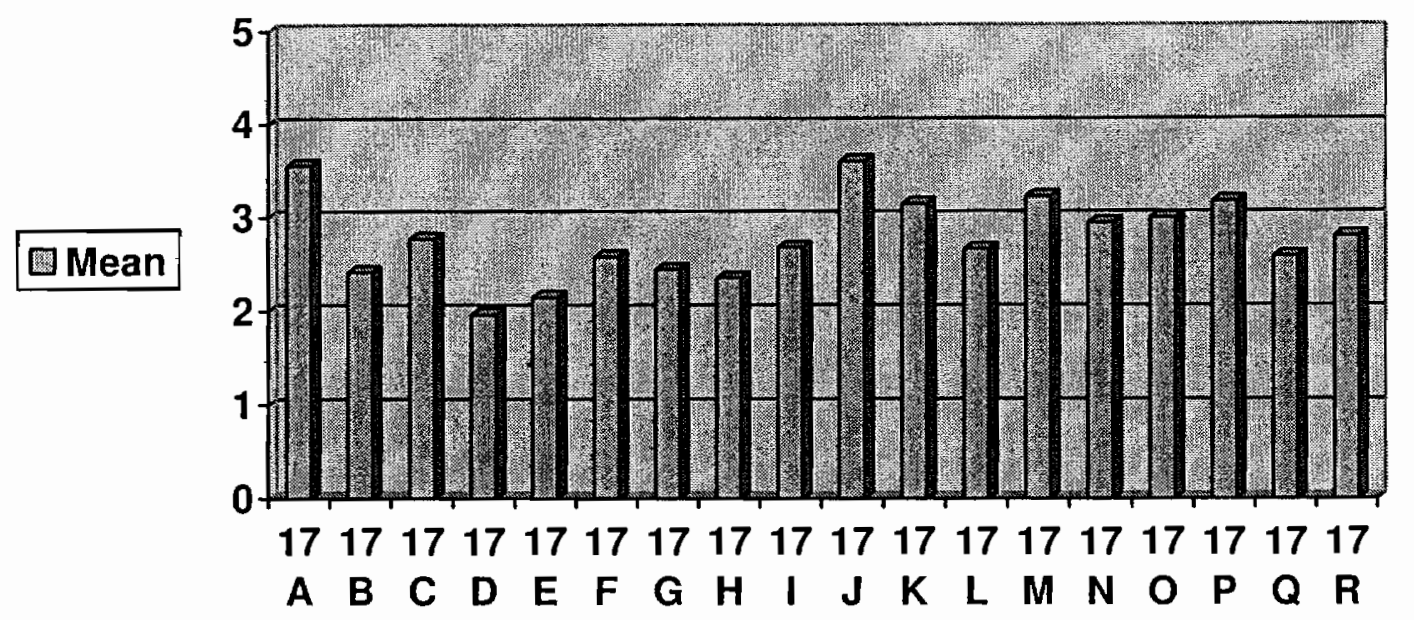

Figure 2. Comparison of means of each causal factor constituting questionnaire item 17

As identified in the previous chapter, two tests were employed in the quantitative analysis of the data, both designed for use with non-parametric data such as the ordinal data generated by questionnaire item 17. The Friedman One-Way ANOVA was used to test the distribution of means of the 18 items as identified in Table 11. All subsequent comparison of causal factor means by associative factor variables was performed by the Kruskal-Wallis One-Way ANOVA, which allows for k-independent sample comparisons. It should be noted that not all items were responded to by all 281 respondents, making for a varied $\mathrm{N}$ on each test conducted. Table 12 identifies the results of the Friedman OneWay ANOVA for the 18 items that constitute the causal factors. 
Table 12

Mean rank values for 18 statements comprising causal factors

Ranks

A. The level of support from the principal and senior management at the school was influential in my decision to leave the school.

Mean Rank

$B$. The quality of the induction program was influential in my decision to leave the school.

12.30

C. Resource support at the school (technological, print or otherwise) was influential in my decision to leave the school.

D. Student behavior at the school was influential in my decision to leave the school.

E. Parental support of teachers was influential in my decision to leave the school.

F. The quality of the school facility was influential in my decision to leave the school.

G. The academic standards of the school were influential in my decision to leave the school.

$H$. The stability of my teaching assignment at the school was influential in my decision to leave the school.

1. Expectations regarding teacher workload were influential in my decision to leave the school.

J. Communication between senior management and faculty at the school was influential in my decision to leave the school.

$K$. The overall compensation package offered to me was influential in my decision to leave the school.

10.90

L. Opportunities for leadership at the school were influential in my decision to leave the school.

$M$. Teacher involvement in decision making at the school was influential in my decision to leave the school.

$\mathrm{N}$. A mismatch between my expectations regarding the school and/or my role and the reality when I arrived was influential in my decision to leave the school.

O. Opportunities for professional advancement elsewhere were influential in my decision to leave the school.

10.46

$P$. Personal circumstances were influential in my decision to leave the school.

10.86

Q. Living conditions in the host country were influential in my decision to leave the school.

$R$. The quality of my personal life while at the school was influential in my decision to leave the school. 
Table 13

Test statistics for Friedman One-Way ANOVA

Test Statistics(a)

\begin{tabular}{|l|r|}
\hline N & 262 \\
Chi-Square & 564.209 \\
df & 17 \\
Asymp. Sig. & .000 \\
\hline \multicolumn{2}{|l|}{ a Friedman Test }
\end{tabular}

As seen in Table 13, with an $\mathrm{N}$ of 262 , degrees of freedom of 17 and a significance level of .000 , it is shown that there are significant differences among the mean rank values of the 18 causal factors. Because the Friedman One-Way ANOVA does not allow for post hoc tests to determine where the differences are, only a visual inspection of the mean rank values is possible.

While it is clear that there is a significant difference between the highest ranking mean values for items $\mathrm{A}, \mathbf{J}$ and $\mathrm{M}$ and the lowest ranking mean values for $\mathrm{D}, \mathrm{E}$ and $\mathrm{H}$, this test only offers a starting point for the analysis of these data. Fortunately the collection of data that will allow for qualitative analysis will shed further light on the main research question seeking to understand which factors were most influential in the responding teachers' decision to leave the school they described.

\section{Causal Factors analyzed by Associative Factors}

Table 3 from the preceding chapter identifies the eight categories of causal factors into which the 18 statements have been placed. It is those eight categories that will be used in coding the written comments for qualitative analysis. At this stage of the quantitative analysis, however, the eight causal factors will be disaggregated and all 18 statements will be analyzed separately by each of the associative factors. The test used 
for this analysis will be the Kruskal-Wallis One-Way Analysis of Variance, in that it allows the distribution of means of each causal variable to be compared by $\mathrm{N}$ number of independent samples, or grouping variables (Hinkle, Wiersma, \& Jurs, 2003). In this way it is possible to determine if any of the different groupings of associative factors provoke significantly different responses on any of the causal factors. For example, will the grouping variable of gender produce significant differences in the responses of males vs. females on each of the causal variables? Because of the number of combinations this creates, it would be cumbersome in the extreme to include all the findings in this chapter. A summary table will be used here to present the findings of this analysis, and the full set of tables is available as Appendix D. By this means the subsidiary research questions will be answered.

\section{Causal Factors by School Characteristics}

Table 14 summarizes the findings of the Kruskal-Wallis One-Way Analysis of Variance test conducted on each of the 18 statements of causal factors, by the different groupings of each associative factor in the school characteristics category. Only those causal factors with significant differences in means by the grouping variables are listed in the table. A subsequent table will examine the findings for teacher characteristics. Discussion of these findings will be reserved for the final chapter. However, as is evident from the number of causal factors with means that are significantly different when broken down by associative variables, the null hypothesis of this study is rejected. 
Table 14

Summary of differences in mean rank distributions of causal factors, by associative school characteristics

\begin{tabular}{|c|c|c|c|}
\hline $\begin{array}{l}\text { School } \\
\text { characteristic }\end{array}$ & $\begin{array}{l}\text { Causal factors with } \\
\text { differences in means }\end{array}$ & $\begin{array}{l}\text { Significance } \\
\text { level }\end{array}$ & $\begin{array}{l}\text { Group with } \\
\text { highest rank }\end{array}$ \\
\hline \multirow[t]{3}{*}{ Size of school } & C. Resource support & $.024 *$ & $1-99$ \\
\hline & H. Stability of assignment & $.043^{*}$ & $1-99$ \\
\hline & \multicolumn{2}{|c|}{ O. Professional advancement $.050^{*}$} & $1-99$ \\
\hline $\begin{array}{l}\text { Perceived academic } \\
\text { strength }\end{array}$ & \multicolumn{3}{|c|}{ circumstances and R. Personal life quality } \\
\hline \multirow[t]{8}{*}{ Ownership structure } & B. Induction program & $.002 *$ & Priv. owned \\
\hline & C. Resource support & $.000^{*}$ & Corp. owned \\
\hline & F. School facility & $.000^{*}$ & Corp. owned \\
\hline & G. Academic standards & $.000^{*}$ & Priv. owned \\
\hline & J. Communication & $.039 *$ & Corp. owned \\
\hline & M. Involvement in decisions & $.037 *$ & Priv. owned \\
\hline & O. Professional advancement & $.002 *$ & Priv. owned \\
\hline & R. Personal life quality & $.022 *$ & Corp. owned \\
\hline
\end{tabular}

Note. ${ }^{*} \mathrm{p} \leq .05$

\section{Causal Factors by Teacher Characteristics}

Table 15 summarizes the findings of the Kruskal-Wallis One-Way Analysis of Variance test conducted on the same 18 statements of causal factors, but this time by associative 
teacher characteristics. Again the full table of data analysis statistics can be found in Appendix D. Discussion of these findings will also be reserved for the final chapter. Table 15

Summary of differences in mean rank distributions of causal factors, by associative teacher characteristics

Teacher

characteristic
Causal factors with

differences in means
Significance Group with

level highest mean

rank

Gender None

Age None

Marital Status
B. Induction program

$.008^{*}$

Single

C. Resource support

$.014^{*}$

Single

F. School facility

$.020^{*}$

Single

H. Stability of assignment

$.006^{*}$

Single

I. Workload expectations

$.024 *$

Single

J. Communication

$.008 *$

Single

R. Personal life quality

$.027 *$

Single

Children

N. Mismatch in expectations

$.015^{*}$

0 and 1

Experience in all schools None

Experience in that school
A. Support from principal
$.000^{*}$
1 year
B. Induction program
$.000^{*}$
1 year
D. Student behavior
$.032 *$
1 year
F. School facility
$.000^{*}$
1 and 2 years 


\begin{tabular}{llll} 
& $\begin{array}{ll}\text { G. Academic standards } \\
\text { H. Stability of assignment }\end{array}$ & $.000^{*}$ & 1 year \\
& J. Communication & $.037^{*}$ & 1 year \\
& N. Mismatch in expectations & $.000^{*}$ & 1 year \\
& O. Professional advancement $.031^{*}$ & 2 years \\
Experience in & Q. Host country conditions & $.023^{*}$ & 2 years \\
international schools & C. Resource support & $.031^{*}$ & $0-4$ years \\
Subject area & L. Leadership opportunities & $.008^{*}$ & 20 plus years \\
Level of education by & None & & \\
Dighest degree & D. Student behavior & $.017^{*}$ & Master's \\
\hline
\end{tabular}

Note. ${ }^{*} \mathrm{p} \leq .05$

\section{Qualitative Analysis}

Having presented the findings offered by participant responses to statements of causal factors, which generated ordinal data, it is now time to turn to the qualitative data collected. Within the questionnaire there were multiple opportunities for participants to write their thoughts on the topic at hand. While such opportunities for input do not constitute interviews, they offer a similar data set, in that participants are allowed to elaborate on the topics introduced by the researcher. In analyzing such data, it is imperative that careful thought is given to how such potentially random thoughts are organized, analyzed and presented. As identified in the methodology section of the previous chapter, for this study all written responses were categorized into two types: 1.) comments fitting into the eight causal factors identified in Table 3, or 2.) comments that 
address a causal variable not identified in Table 3 . The questionnaire contained six separate comment boxes that allowed participants to write their thoughts with no limitation on the word count. All six sets of responses were analyzed separately, with comments being coded and tabulated according to the eight categories of causal variables as identified in Table 3, hereafter called type 1 comments. Type 2 comments, meaning those that do not fit into the existing categories, were compiled and analyzed inductively to determine if a new category was merited. The full set of comments is available as Appendix E. The researcher has performed only minor editing, including the removal of names and places to preserve anonymity. Table 16 offers a legend of the abbreviations used in Appendix E for each category of causal variable. It should also be noted that the initial phase of coding comments was completed in advance of the quantitative analysis. By this means the researcher attempted to reduce bias in the categorization of comments, as he did not yet know which causal factors would prove to be significant.

Table 16

Abbreviation legend for coding causal factors

Causal Factor category from Table 3

Administrative leadership

Working Conditions

Compensation

Student Discipline

Academic Standards

Host Country Characteristics

Personal Factors
Abbreviation used in comment analysis

$\mathrm{AL}$

WC

Comp.

SD

AS

$\mathrm{HCC}$

PF 

PA

Each of the six opportunities for participants to respond will be treated in a separate table, appearing below as Tables 17 to 22 . In addition to categorizing comments into the eight causal factors, each causal factor will be grouped into School Characteristics, Host Country Characteristics or Teacher Characteristics. Both type 1 and type 2 comments as identified above will be tabulated in the table for each question.

Table 23 shows the aggregated results of Tables 17 to 22 .

\section{Table 17}

Summary of comments for question 18: "Please feel free to add explanatory comments for any of the items in the above question."

\section{Type 1 comments}

Construct category - Causal Factors (Identified) Number of responses

School Characteristics

Administrative Leadership

Compensation 17

Working Conditions 15

Academic Standards

4

Student Discipline

1

Host Country Characteristics

Teacher Characteristics

Personal Factors

Professional Advancement 


\section{Type 2 comments}

Possible New Causal Factors Number of responses

Profit incentive affected school operations 7

Conflict with administrator

6

Contractual issues

3

Conflict between Board and Head

2

Private ownership of school 1

Total causal factor responses for Q 18: 168

Total individuals responding to Q 18: 122

\section{Table 18}

Summary of comments for question 19 a: "What were the top three reasons that prompted you to leave the school?"

\section{Type 1 comments}

Construct category - Causal Factors (Identified) Number of responses

School Characteristics

Administrative Leadership

Compensation

Working Conditions

Academic Standards

Student Discipline

Host Country Characteristics

Teacher Characteristics 
Personal Factors

Professional Advancement
60

$\underline{17}$

234

\section{Type 2 comments}

Possible New Causal Factors

Contractual issues

Misrepresentation during recruitment

Private ownership of school

Conflict with administrator

Visa problems

Conflict between Board and Head

School closure

Profit incentive affected school operations

Location of school in city

Dismissal

Ambiguous responses

Total causal factor responses for Q 19a:

Total individuals responding to Q 19a:

\section{Number of responses}

7

7

5

4

4

2

2

1

1

I

6

274

273

Table 19

Summary of comments for question $19 \mathrm{~b}$ : "What were the top three reasons that prompted you to leave the school?"

\section{Type 1 comments}

Construct category - Causal Factors (Identified) Number of responses 
School Characteristics

Administrative Leadership 65

Compensation $\quad 30$

Working Conditions 23

Student Discipline $\quad 8$

Academic Standards 3

Host Country Characteristics 33

Teacher Characteristics

Personal Factors $\quad 52$

Professional Advancement 19

233

Type 2 comments

Possible New Causal Factors Number of responses

Misrepresentation during recruitment 6

Private ownership of school 4

Profit incentive affected school operations $\quad 2$

Board issues 2

Low student numbers $\quad 2$

Quality of colleagues $\quad 2$

Ambiguous responses $\quad 7$

Total causal factor responses for Q 19b: 258

Total individuals responding to Q $19 \mathrm{~b}: \quad 255$ 
Table 20

Summary of comments for question $19 \mathrm{c}$ : "What were the top three reasons that prompted you to leave the school?"

\section{Type 1 comments}

Construct category - Causal Factors (Identified) Number of responses

School Characteristics

Administrative Leadership

Working Conditions

Compensation

Academic Standards

Student Discipline

Host Country Characteristics

Teacher Characteristics

Personal Factors

62

Professional Advancement

14

204

\section{Type 2 comments}

Possible New Causal Factors

Issues among staff

Private ownership of school

Profit incentive affected school operations $\quad 2$

Board issues 
Misrepresentation during recruitment

Sexual harassment/discrimination $\quad 2$

Ambiguous responses 13

Total causal factor responses for Q $19 \mathrm{c}$ : 239

Total individuals responding to $\mathrm{Q} 19 \mathrm{c}$ : 235

Questions 20 and 21 are presented together in Table 21, and bear some clarification. Question 20 asked respondents if there was anything the school's administration could have done to prevent them from leaving in that year. All 281 respondents answered, with 131 saying "No" and 150 saying "Yes". However, the written responses in question 21 , intended to explain the answer offered in question 20 , overlapped in terms of the causal factors they addressed. For this reason Table 21 identifies the breakdown of how many of each causal factor statements were from the "No" answers vs. from the "Yes" answers.

Table 21

Summary of comments for question 21: "Please explain your answer for the above question." (Q. 20 'Was there anything the school's administration could have done to prevent you from leaving that year'?)

\section{Type 1 comments}

Construct category - Causal Factors (Identified) Number of responses (Q. 20 answer)

School Characteristics

Administrative Leadership

Compensation

Working Conditions
$90 \quad(15 \mathrm{~N}, 75 \mathrm{Y})$

$36 \quad(8 \mathrm{~N}, 28 \mathrm{Y})$

$14(6 \mathrm{~N}, 8 \mathrm{Y})$ 


$\begin{array}{ccc}\begin{array}{ccc}\text { Student Discipline } \\ \text { Academic Standards }\end{array} & 2 & (1 \mathrm{~N}, 1 \mathrm{Y}) \\ \text { Host Country Characteristics } & 1 & (\mathrm{ON}, 1 \mathrm{Y}) \\ \text { Teacher Characteristics } & 10 & (10 \mathrm{~N}, 0 \mathrm{Y}) \\ \text { Personal Factors } & & \\ \text { Professional Advancement } & 43 & (40 \mathrm{~N}, 3 \mathrm{Y}) \\ & 7 & (2 \mathrm{~N}, 5 \mathrm{Y})\end{array}$

\section{Type 2 comments}

Possible New Causal Factors

Misrepresentation during recruitment

Contractual issues

Owner interference in operations

Conflict with administrator

Profit incentive affected school operations

Clear-out of previous staff

Low enrollment numbers

School closed

School too set in ways

Board issues

Ambiguous responses

Total causal factor responses for Q 21:

Total individuals responding to $Q 21$ :
Number of responses (Q. 20 answer)

$15 \quad(1 \mathrm{~N}, 14 \mathrm{Y})$

$12(2 \mathrm{~N}, 10 \mathrm{Y})$

$7 \quad(3 N, 4 Y)$

$6 \quad(2 \mathrm{~N}, 4 \mathrm{Y})$

$5 \quad(2 \mathrm{~N}, 3 \mathrm{Y})$

$3 \quad(2 \mathrm{~N}, 1 \mathrm{Y})$

$1 \quad(1 \mathrm{~N}, 0 \mathrm{Y})$

$1 \quad(1 \mathrm{~N}, 0 \mathrm{Y})$

$1 \quad(1 \mathrm{~N}, 0 \mathrm{Y})$

$1 \quad(0 \mathrm{~N}, 1 \mathrm{Y})$

$26 \quad(18 \mathrm{~N}, 8 \mathrm{Y})$ 


\section{Table 22}

Summary of comments for question 22: "Do you have any further comments regarding your departure from this school?"

\section{Type 1 comments}

Construct category - Causal Factors (Identified) Number of responses

School Characteristics

Administrative Leadership

Compensation

Working Conditions

9

Student Discipline

4

Academic Standards 1

Host Country Characteristics

Teacher Characteristics

Personal Factors

14

Professional Advancement

90

\section{Type 2 comments}

Possible New Causal Factors Number of responses

High turnover 8

Quality of colleagues

Profit incentive affected school operations

Owner interference in operations

Board issues 
Misrepresentation during recruitment $\quad 1$

School location 1

Supplementary comments $\quad 52$

Ambiguous responses 7

Total causal factor responses for Q 22: 174

Total individuals responding to Q 22: $\quad 159$

Table 23

Aggregated Type 1 comments from Tables 17 to 22

Construct category - Causal Factors (Identified) Number Percentage of responses of responses

School Characteristics

Administrative Leadership 346

31.0

Compensation

146

13.1

Working Conditions

107

9.6

Student Discipline

23

2.0

Academic Standards

24

2.2

Host Country Characteristics

127

11.4

Teacher Characteristics

Personal Factors

265

Professional Advancement

75

$\underline{6.7}$

Total Type 1 comments

1113

99.8 
The process of aggregating type 2 comments was considerably more complicated than type 1 comments. The inductive process of categorizing comments that did not fit into existing causal factors had a degree of subjectivity to it. As indicated earlier, this subjectivity was minimized with the use of a process called the "analytical framework" approach described by Patton (2002, p. 439), which isolated from respondents' comments those variables to which they ascribed their decision to leave the school, i.e. causal factors. As this process was completed separately for each of the six opportunities for participants to respond, it generated six separate lists of possible new causal factors. Only after completing the first phase of this analysis could the researcher then return to review the six lists together, to see where overlap allowed him to create new groupings to more accurately reflect the collective statements respondents made regarding variables that influenced them to leave the school.

This process led to the creation of five new categories that will bear discussion in the following chapter. The first category blended the following type 2 causal factors; “Profit incentive affected school operations", "Private ownership of school", "Owner interference in operations" into one category labeled "Issues stemming from private ownership". Comments from this category were present in all six banks of comments. The second category did not require blending, as it was consistently labeled throughout as "Misrepresentation during recruitment". This category appeared in five of the six banks of comments. The third category appeared in all six comment banks and centered around conflict with and among the administrative leadership, using the following labels; "Conflict with administrator", "Conflict between board and head", and "Board issues". The new label used to group these was called "Conflict with school leadership". The 
fourth category was consistently labeled throughout as "Contractual issues", and appeared in three of the six comment banks. The final new category focused on participants' colleagues, using the labels of "Quality of colleagues" and "Issues among staff", and appeared in three of the six banks. The new label used was "Dissatisfaction with colleagues". All other categories were deemed to be insufficient to merit the creation of a new category of causal factor. Table 24 summarizes the breakdown of the new categories, relative to overall type 2 comments.

Table 24

Aggregated Type 2 comments from Tables 17 to 22

New Causal Factor
Number of responses

47

31

26

22

19

23

168
Percentage of responses

27.9

18.4

15.5

13.0

11.3

Single digit categories combined 13.7

99.8 


\section{CHAPTER V \\ DISCUSSION AND CONCLUSION}

In this final chapter the findings presented in the previous chapter will be discussed, leading to conclusions that will answer the main research question and both subsidiary research questions. Each of the main research question and two subsidiary research questions will be addressed in separate sections, using the findings offered by both the quantitative and qualitative analyses of the previous chapter. This discussion will reveal implications and suggest recommendations for the practices of international school administrators. Finally, recommendations for future research will be offered.

\section{Main Research Question}

The main research question of this study is, "What variables do international school teachers who leave at the end of a first contract with a school describe as influential in their decision to leave that school?" The quantitative data collected to answer that question was in the form of 18 statements identifying possible causal factors, to which participants were asked to respond with Likert scale choices, 1 being strongly disagree and 5 being strongly agree. The middle choice of 3 allowed for participants to remain neutral, or undecided, on any given statement. Thus, the starting point for examining the data is to see which of the 18 mean scores are above 3 , the center point in the set of choices, a sort of "neutral null hypothesis" (Rhodes, Nevill, \& Allan, 2004, p. 70). In the most basic fashion, this constitutes the answer to the main research question, as only those variables are what the responding teachers collectively describe as influential in their decision to leave the school. 
Using that standard, five statements emerge with means greater than 3 . Table 25 summarizes the salient details for each statement, presented in the order of their mean rank value. The full range of causal factors is available in Table 3.

Table 25

Questionnaire statements with means greater than three

Questionnaire $\quad$ Central idea Mean rank Causal factor

item number of statement response value represented

$17 \mathrm{~J}$

Commun. between senior

3.60

12.61

Administrative

management and faculty

leadership

$17 \mathrm{~A}$

Support from principal

3.56

12.30

Administrative

and senior management

leadership

$17 \mathrm{M}$

Teacher involvement in

3.22

11.29

Administrative

decision making

leadership

$17 \mathrm{~K}$

Compensation package

3.15

10.90

Compensation

$17 \mathrm{P}$

Personal circumstances

3.18

10.86

Personal

factors

As identified in the previous chapter, the test performed on these data, the Friedman One-Way Analysis of Variance, indicated a statistically significant difference between the highest means and the lowest means. While no post-hoc test is available for 
non-parametric tests such as Friedman's, it seems reasonable using the recommended visual inspection of the data (George \& Mallery, 2003, p. 218) to include these five statements in the group that are significantly different than the bottom mean score of 1.96 and corresponding mean rank value of 6.32. Comparing the mean rank values generated with Friedman's test, shown in Table 12, these same five statements again surface as the top five, as shown in Table 25 . Only the $4^{\text {th }}$ and $5^{\text {th }}$ spots change between the two measurements of means vs. mean rank values. It is worthy to note that of the five statements that surfaced as most important, the top three fall into one causal factor category, Administrative Leadership. That three of the eighteen overall choices rank at the top, and fit into one category, is a strong statement indeed. This particular finding is very consistent with one of the landmark studies conducted in the US (Ingersoll, 2001), in which administrative support and faculty involvement in decision making was found to be significantly correlated to teacher turnover. A more recent study using equally robust data also supports similar findings (Ware \& Kitsantas, 2007). Each of the other two statements showing compensation and personal circumstances to have significance in influencing expatriate teachers to leave international schools also has precedent in the literature studying teacher turnover in the US (Imazeki, 2002; Ingersoll, 2001; Stinebrickner, 2001).

The above findings are also supported by comparing these data with the comments offered in the qualitative dimension of the study. Comments offered by respondents were categorized and tabulated in the two ways described in the previous chapter. As shown by Table 23, the construct category of Administrative leadership (AL) generated over $30 \%$ of all comments that fit into type 1 categories of causal factors. 
While no test of statistical significance was applied to this data, as they were generated by the researcher coding the comments, it is noteworthy that this one category generated such a high percentage of respondents' comments. Examining the composition of the eight categories of causal factors as shown in Table 3, one might argue that AL has the advantage of including four statements in that category. However, it should also be noted that the category of Working conditions (WC) included five statements, yet generated less than one third as many comments as $\mathrm{AL}$, and also did not factor into any of the five significant means shown in Table 25.

In addition to the frequency of comments on this topic, the strength of feeling was also very clear. Following are some excerpts taken from the comment banks. "Basically, I left due to the way I was treated. The lack of appreciation for me as a teacher was astounding." "Poor and bullying management." "They (administration) were constantly sabotaging each other and had little time for concerns that the staff actually cared about." "No one knew where he/she stood....Few positive remarks were made." "Management was totally autocratic and there was a definite lack of communication between management and teaching staff." There can be little doubt that for many of this group of expatriate teachers, the administrative leadership at their school was an influence in their departure. This conclusion is reminiscent of the findings of studies conducted by Ingersoll (2001) and Johnson \& Birkeland (2003).

The causal factor ranking fourth in the list of mean rank values was that of compensation. Its mean score was actually fifth, but the differences on both mean score and mean rank value between this causal factor and the statement of Personal circumstances was very slight. In the context of this study, compensation was considered 
a school characteristic, in that international schools are most often highly independent organizations, each of which determines the compensation package that is offered to their employees. This differs from most studies regarding teacher turnover, particularly those using data from the US, where most data comes from large public school districts. In that context compensation would not be considered a school characteristic. Nonetheless, numerous studies support the conclusion that compensation contributes to teacher turnover (Imazeki, 2002; Ingersoll, 2001; Stinebrickner, 2001; Webb et al., 2004). Differences in the breakdown of respondent demographics between this study and one of the above cited studies will be addressed in the section on associative teacher characteristics.

Again the quantitative findings regarding compensation are supported by the qualitative findings. As shown in Table 23, this causal factor again ranked in the top three, along with the other two factors represented in Table 25. Comments focusing on compensation as a causal factor constituted $13.1 \%$ of the overall type 1 comments. This percentage might have been higher, but the researcher chose to categorize comments regarding the tax structure of the host country into the causal factor category of Host country characteristics (HCC). It might be argued that a suitable compensation would offset a tax burden, but for the purpose of this study, such comments were placed in the HCC category. Comments in this section did not tend to have the depth of emotion that typified many in the previous category (AL). Following are some examples of comments relating to compensation. "We were unable to live on the salary they paid us, as a result we had to use our retirement to get by year to year." "Salary not enough to live comfortably with non-working spouse - moved to a place with better opportunities for 
spouse." "The main reason for leaving was that we could not maintain our mortgage at home on the salary package I was on."

The final statement from Table 25 was the one that focused on personal circumstances, and fit into the causal factor category of Personal factors (PF). With a mean rank value of 10.86 , it was very close to the fourth ranking statement of compensation at 10.90 . Previous studies often show a correlation between certain personal circumstances and teacher mobility, such as having children (Guarino, Santibanez, \& Daley, 2006), but few examine personal circumstances as causal factors. One such study that did utilize qualitative data generated by a series of surveys did show personal factors to be influential in teacher attrition (Elfers, Plecki, \& Knapp, 2006).

In this case the qualitative data offer both strength of frequency and depth of detail to the picture. The category of Personal factors (PF) generated $23.8 \%$ of all type 1 comments. While some participants offered little by way of detail, others were very candid and detailed about the personal circumstances that provoked them to leave the school. Certainly one of the most common was the desire to experience new cultures and travel in new countries, but there were also a wide range of other circumstances.

Following are some excerpts from the comment banks. "I wanted to learn about a new culture and a new country was a big (if not the biggest) reason for leaving." “...concern for the safety of my ethnically ___ girlfriend on the streets of ___ was a factor in our decision to leave." "Grown up children in UK now producing my grandchildren - too far away to keep visiting." "My wife (also teaching at the school) was committed to 2 years away from pets/family in Canada. She was ready to come home after the two years." The quality of my personal life." "Boredom." "Exhaustion." "Engaged." "I wanted to return 
to teaching children with greater learning difficulties than the international school would admit."

Also relevant in answering the main research question is the qualitative data called type 2 comments. This category was an acknowledgment on the part of the researcher that the survey instrument might not provide all possible causal factors by way of the 18 statements in item 17 . Thus he allowed for participants to offer open-ended comments to see if there were other factors that seemed to merit the creation of new causal factors not previously identified in the literature. Table 24 in the previous chapter identifies five new causal factors, and the process by which they were determined. Each of them bears some discussion.

The first new causal factor was labeled "Issues stemming from private ownership", and comprised $27.9 \%$ of all type 2 comments. Not only did it rank as the highest in frequency, appearing in all six banks of comments, it also included the most emotively laden language. Terms like "profiteering", "profit incentive", "poor resources vs. huge profits", "dictatorial owner", "lies and manipulation...from owner" were typical of the comments indicating the perceptions toward the private ownership of respondents' schools. Additionally it should be noted that a somewhat skewed percentage of respondents chose to describe privately owned schools in completing the questionnaire. As shown in Table 8 , in the 2006 data collected by the E/CIS, $26.1 \%$ of responding schools fit into the category of privately owned, vs. $62.5 \%$ being trust/not-for-profit schools. In this study, $44.1 \%$ of respondents chose to describe privately owned schools, vs. $49.1 \%$ trust/not-for-profit schools. While it is speculative, to be sure, it might be argued that the difference in percentages was provoked because of the depth of feeling on 
the part of teachers who had negative experiences at proprietary schools. People respond to survey invitations for a host of reasons, and perhaps in this case it was because of the need to share their unhappy experiences. Unfortunately nothing in the literature sheds light on this phenomenon, as no study found by this researcher explored the impact of private ownership on teacher perceptions. There is some similarity to a study of turnover among international school heads that pointed to governance issues as the most frequent reason for leaving (Hawley, 1994, 1995). However, it is a topic that will be returned to in the recommendations section of this chapter. One simply cannot ignore the power of statements such as this one. "I gave this proprietary school a chance, even having heard horror stories about for-profit schools. But after my experience there, I will never work for a proprietary school again."

The second new category of causal factor was labeled "Misrepresentation during recruitment", and generated $18.4 \%$ of type 2 comments. This topic also generated some strong language regarding teachers' perceptions of how they were treated in the recruitment phase of the hiring cycle. The following are some examples from the comment banks. "Mismatch between what I was told in interview and what the real situation was." "Chances to teach what my original contract said were nil." "Promises regarding salary and conditions promised at interview not fulfilled." "Lies about package during recruitment procedure." "School misrepresented itself. Not international with $90 \%$ student population being Portuguese." As Garton identified (2000, p. 86), the recruitment of new teachers may be the most important responsibility carried by an international school head. As such, his treatment of this issue focused primarily on how the head can develop efficient and effective recruitment practices. In his treatment of the 
subject, Cambridge (2002) focused on the impact of globalization on recruitment trends. In his description of the phases of the recruitment process, Hardman (2001) touched on the need for clarity and accuracy in presenting the school's profile. Hayden (2006) discussed the complexity of the recruitment process with attention to both the recruiter's and the applicant's point of view, and offered insight into possible reasons why first-time international teachers might feel that the situation was misrepresented when they arrive and take up the job they accepted. What is clear from the findings of the current study is that when teachers feel that the situation has been misrepresented during the recruitment phase, they sometimes choose to leave the school.

The third new causal factor was labeled "Conflict with school leadership", and generated $15.5 \%$ of all type 2 comments. It might be argued that this topic could be folded into the existing category of Administrative leadership, but this researcher felt that many of the comments went beyond a simple judgment that the leadership of the school was not competent. It seemed that often the comment indicated that the conflict with the leader had become personal and hurtful. The following are examples of comments classified in this category. "The owner was uncaring about the school and a nasty person who had sycophantic, mean-spirited people working for him." "I felt that the Head of the school wanted only British teachers, and, as she was not there when I was initially hired, it was evident that she couldn't wait to get me out." "Professional jealousy and a hate campaign directed by the senior administrators at me drew my job to a conclusion." "The new director was openly hostile to me and made it pretty impossible to stay." None of the studies focusing on national data seem to extract this type of scenario in their analyses. Given the paucity of actual studies drawn from international school data, it is 
not surprising that there are no parallel findings available there either. However, several sources describe the nature of international school teaching in a way that is helpful in understanding the phenomenon revealed in this study.

The complexity of international schools is well documented (Joslin, 2002; Stirzaker, 2004), as is the commensurate complexity of international school leadership (Blandford \& Shaw, 2001; Hayden, 2006). While this principle is true of schools the world over, in the climate described above, relationships among the constituents of the international school community become increasingly important. Faced with the challenges of culture shock, language barriers, potentially adverse living conditions, and a host of other possible challenges, international school communities come to rely heavily on support from within their own community. When relationships go sour, particularly between senior administrators and members of their staff, the potential for feelings such as those expressed in this study are perhaps higher in international schools than in other contexts.

On that note, it may be worth momentarily skipping over the fourth new category to address the fifth, which is "Dissatisfaction with colleagues", responsible for $11.3 \%$ of type 2 comments. In much the same way that their relationships with their administrators have substantial influence on international teachers' overall quality of life, perhaps even more so is this the case with their colleagues. In this study, 19 comments surfaced that pointed to dissatisfaction with colleagues as influential in the teacher's decision to leave. The following are some examples. "I also felt that the staff there were quite unprofessional in their behavior, constantly backbiting and involving themselves in other people's private affairs." "Being in the school attracts many teachers who are 
there for personal enjoyment and almost see it as a bit of a holiday posting. The quality of the teaching in some departments was low, and as a member of a very hard working department with a heavy workload of marking this was in the end making me too angry." "The poor quality of other teachers." "Negativity throughout the preexisting staff."

The final new causal category, which ranked fourth in the list, was labeled "Contractual issues" and generated $13.0 \%$ of the type 2 comments. This feature of international school hiring practices is well documented in the literature as a constant source of friction among staff and between staff and administrators (Cambridge, 2002; Garton, 2000; Hayden, 2006; Richards, 1998). The most common feature of contractual dissatisfaction is the practice of offering several categories of contract, often for teachers filling the same positions. Put simply, teachers hired on a local contract are often paid a fraction of what teachers hired on an overseas contract are paid. This issue certainly featured heavily in the comments offered in this study. There were additional specifics, such as the desire for more home leave, that seem to have factored heavily in the respondents' decision to leave the school. The following are samples taken from the comment banks. "Some teachers were offered different contracts and pay scale to others when they threatened to leave in order to reduce the turnover of staff." "Therefore this promise of a position later on came down to finances. Obviously local hires were cheaper." "Retirement age 62 and they take away one's housing." "Ambiguity over contract renewal i.e. teachers asked to sign contracts without knowing their salary or benefits." 


\section{Subsidiary Research Questions}

Having looked closely at the findings that address the main research question, it is now time to turn to each of the subsidiary research questions. Those questions are:

a.) Are there differences in identified key causal factors by associative school characteristics?

b.) Are there differences in identified key causal factors by associative teacher characteristics?

In keeping with protocol for research procedures, the null hypothesis is that there will be no significant difference in the mean rank values of causal factor scores by associative factor populations, as shown in the Kruskall-Wallis One-Way Analysis of Variance test. The alternative hypothesis is that at least two of the associative factor populations will differ on one or more of the causal factor mean rank scores. The findings presented in the previous chapter, summarized in Tables 14 and 15 , form the basis of this discussion. As can be seen from the number of significant differences among the associative factor populations for several causal factors, the null hypothesis was rejected.

Each causal factor has been analyzed by the various distributions of means of all associative factors. While the above mentioned tables present the full set of findings, the discussion earlier in this chapter eliminated all but three causal factors (represented by five statements) as having significance. Thus, in keeping with the purpose of subsidiary research questions to probe for further understanding of the main research question, only those three causal factors, or five statements, will be discussed. They are what the subsidiary questions refer to as "key causal factors". Additionally, only those causal 
factors that showed statistically significant differences in the means of the various associative factor groupings will be discussed. While the focus of this study is on understanding causal factors, the organization of discussion in this section is by associative factors.

\section{Subsidiary Question a.)}

The first associative factor by which the causal factors were analyzed was school size. For this associative factor, three causal factors had differences in the distribution of means. However, as none of them were included in the group of three significant factors, no discussion is necessary.

The second associative factor was perceived academic strength. This analysis showed that all but two of the 17 statements had significant differences by the groupings in this associative factor. Of this sizable group, four of the significant causal factors were included. Taken at its most basic level, these data show that teachers who left in part because of the academic standards also rated statements $\mathrm{A}, \mathrm{J}$ and $\mathrm{M}$ (Administrative leadership) significantly higher than those teachers for whom academic standards were not an issue. That is not surprising, given the connection between academic standards and administrative leadership. The fourth causal statement, compensation, drew the highest mean from teachers who "agreed" with the statement regarding academic standards, meaning that was the group who also felt compensation was an influential factor in their departure. This does not seem to bear further commentary.

The third and final associative school characteristic to address is ownership structure. The two key causal factors with means that differed significantly by this 
associative factor were: J. Communication and M. Involvement in decisions. The highest mean rank grouping variable for communication was "corporation owned" and the highest mean rank grouping variable for involvement in decisions was "privately owned", although in each case these two associative factors were close to each other relative to the mean rank for the grouping of "not-for-profit/trust". As mentioned in the discussion regarding the main research question, this associative factor was so consistently mentioned in the comments that it has been deemed a new causal factor. Although there is little in the literature surrounding this topic, one recent publication has made mention of it. Hayden (2006) devotes a chapter in her book on international education to the nature of leadership in international schools, and alludes to a number of challenges particular to leadership in privately owned international schools. Given the possible complexity and ambiguity of governance in these schools, it should be little surprise that teachers who chose to leave them rated communication and involvement in decision making as more influential factors than teachers who left not-for-profit/trust schools. Again this is a topic that will be addressed in the implications section of this chapter.

\section{Subsidiary Question b.)}

The first two associative factors to examine are gender and age of respondents. Ironically, neither of these associative factors had significant differences among their populations on any of the causal factors. The irony lies in the fact that these two associative factors figure prominently in many of the existing studies regarding teacher turnover. Ingersoll (2001) indicated that younger teachers were 171 percent more likely to depart a school than middle aged teachers. Imazeki's study (2002) showed that male teachers were more responsive to better salary as a reason for leaving a school than were 
female teachers. A study conducted in Norway (Falch \& Strom, 2002) found that younger male teachers were more likely to quit the profession. What then does it mean that in this study there were no differences in causal factors by these associative factors? In the absence of additional data to explore this question, the only conclusion to be drawn is that for this group of 281 teachers, there were no significant differences by age and gender on the reasons why they left the school. Regardless of age or gender, their reasons for leaving the school were equally distributed. In short, in this study, neither gender nor age served as a predictor of how respondents would view causal factors.

The third associative factor was marital status, which revealed a difference in means for only one of the key causal factors, J. Communication. Single teachers had the highest mean rank on this causal factor. Again the literature is relatively silent on this topic. One study (Stinebrickner, 2001) did identify that for women, marital status and number of children were important predictors of exiting from the teaching workforce.

The fourth associative factor was children, and this factor did not reveal any differences in the means of its populations on key causal factors. The fifth associative factor, experience, was comprised of three statements in the questionnaire. Two of them, experience in all schools and experience in international schools, showed no significant differences among their population means on key causal factors.

The third statement in the category of experience was experience in that school, and it revealed significant differences in the means of its population on two key causal factors, A. Support from principal and J. Communication. Not surprisingly, the group who showed the highest mean rank on both of these causal factors was the group who had 
been at the school only one year. It is understandable that teachers who left the school after only one year would see a causal factor such as Administrative leadership as more influential in their departure than those who had been at the school longer. Few studies in the literature focus on length of service at a school as an associative factor. While sizable data exists to show high attrition rates in the US from the teaching profession in the early years (Ingersoll \& Smith, 2003), no such parallel exists on the international school front.

The sixth associative factor was subject area, and it did not show any significant differences on any of the key causal factors. The seventh and final associative factor was level of education, and that also showed no significant differences on any key causal factors.

Thus, in considering the combined answers to the two subsidiary questions, there were statistically significant differences among the key causal variables by associative factor populations, for both teacher and school characteristics. The most common causal factor to provoke these differences was questionnaire item $17 \mathrm{~J}$, "Communication between senior management and faculty at the school was influential in my decision to leave the school." This statement was also the highest ranking causal factor of all 18 statements. However, why this one seemed to polarize responses by associative characteristics more frequently than the second ranked causal factor, support from principal and senior management, is difficult to determine from the data collected in this study. 
The fact is that very few instances of significant differences surfaced in this study. Specifically, there were 12 statements of associative factors, each of which was used to compare differences in mean rank values for the five statements of key causal factors. That means that there were a total possible 60 comparisons, only nine of which proved to have significant differences among their population means. Given that each of these associative factors was drawn from studies in which they had proven to be significant, the finding of this study is somewhat surprising. One clear possibility in interpreting this finding is that there are substantial differences in the contexts of studies drawn from national data vs. studies drawn from international data. Teaching internationally is not the same as teaching in one's home country. While that seems like a statement of the obvious, it certainly points to the need for future research in international schools.

The overall interpretation of the relatively few instances of significant differences by associative factors is that few parameters exist for the answers to the main research question. The three causal factors that were rated highly crossed virtually all populations of associative factor populations. This is a point to be touched on in the next section of this chapter.

\section{Recommendations}

\section{Implications for international school administrators}

In combining the type 1 causal factors and type 2 causal factors into one list of key causal factors, eight factors emerge. These factors are summarized in Table 26. The table is presented at this late stage in the discussion because of the powerful message it communicates to international school administrators. 
Table 26

Combined list of key causal factors, abbreviated

Type 1 causal factors

Mean rank Type 2 causal factors

Rank by

order

comments

$\begin{array}{llll}\text { Administrative Leadership } & 1 & \text { Private ownership } & 1 \\ \text { Compensation } & 2 & \text { Misrepresentation/recruit. } & 2 \\ \text { Personal Factors } & 3 & \text { Conflict with leaders } & 3 \\ & & \text { Contractual issues } & 4\end{array}$

Colleagues

5

For an international school administrator, this list has sobering implications, for this is a summary of why some of our teachers have said they left the school at the earliest opportunity. It is sobering because three of the eight categories above fall squarely on the shoulders of said administrators, and two others are shared with the governing body of the school. Only one is clearly out of the purview of the administrator, the type 1 category of personal factors. All others have strong implications for two categories of school leaders.

The first group is the one referenced above, comprised of the principal, superintendent, director or head of school depending on the institution, and his or her senior leadership team. It falls to this group to address the level of support offered to teachers, to communicate well with them, to offer them appropriate opportunities for involvement in decision making, to represent the school accurately when teachers are being recruited, and to minimize the impact of inter-personal conflict when it occurs. While none of these facts should be new to international school administrators, the degree 
to which these factors push teachers out of a school may well be a surprise. Any factor that exacerbates an admittedly high turnover rate in international schools must be examined closely by administrators. When so many of them seem to point to the effectiveness of the leadership of the school, administrators have the sobering responsibility to address their own practices in light of the details revealed in this study. Administrators would do well to read the entire set of six comment banks, attached to this study as Appendix E, as a starting point to reflect on practices that provoke teachers to leave. It would also be wise for this group to consider implementing a policy that exists in Florida, where principals are required to conduct exit interviews with all teachers who are resigning (Kersaint, Lewis, Potter, \& Meisels, 2007, p. 776). This data is collected by the state Department of Education, which would be more challenging for international school administrators to orchestrate, but not impossible. Collecting and sharing such data could prove invaluable in addressing the issue of high teacher turnover.

The second group of school leaders is the group that comprises the board of directors or trustees, depending on the institution. First, compensation must be reasonable relative to that of a teacher's home country, balanced against living expenses of the host country. As Cambridge (2002) pointed out, expatriate teachers often remove themselves from pension schemes in their home countries, risking potential long term financial exposure. Boards must also consider the complexities of contractual issues, starting with policies that are both transparent and consistent among staff. For example, the establishment of a set of criteria to identify teacher characteristics by which he or she is compensated is an excellent practice. Of course, it must be universally applied to be effective. The practice of offering local contracts to local hires is not likely to disappear 
soon, given the financial exigency of such a practice. Nonetheless, it should be considered as to how to best manage the potential for dissatisfaction among staff provoked by this policy.

The directors or boards of both privately owned and corporation owned schools have a special responsibility, as shown by the comments offered in this study. Clearly there is a strong perception that decisions made in proprietary schools are driven by a profit incentive. While that may or may not actually be the case, it points to the need for transparency in the financial statements and budgetary decision making procedures of such schools. This perception of "profiteering" is exacerbated when directors of proprietary schools are seen to be directly involved in the management of the school, sometimes referred to as micromanaging. The governance structure of proprietary schools needs to be as transparent as their financial statements. If the lines of authority for decision making are well defined, making for a clear understanding on the part of all school constituents, the likelihood of accusations of profiteering will be minimized. If at all possible, board chairs or key directors should attend a board training workshop. There exist many such sessions, including an excellent one offered by the cooperating organization for this study, the Council of International Schools.

Two of the eight categories in Table 26 have little or no direct responsibility for school leaders. Personal circumstances are always going to factor heavily on a teacher's decision to leave a school. The only implication for a school leader is to offer the best support that can be reasonably expected in the context of the decision. The issue of dissatisfaction with colleagues has some bearing on a school leader, as he or she must 
take responsibility for shaping the climate of the school. However, this is a responsibility that truly must be distributed to all members of a school community.

\section{Recommendations for future study}

1. There is a need to explore the impact of age and gender differences in causal factors for teachers leaving international schools.

2. The paucity of data sources for international educators revealed by this study points to the need for systematic data collection, perhaps by placement service agencies, which could be shared with all international school organizations.

3. A study examining the optimal length of stay for expatriate teachers in international schools would help guide administrators in shaping policies to achieve that optimal length with their staff.

4. There is a need for international school administrators to know what contract options are being utilized among sister international schools, and their perceived effectiveness in managing staff morale.

5. This study has focused on the reasons international school teachers left a school. It would be useful to parallel this study with one focusing on international school administrators.

6. A study tracking recruitment strategies with longevity and effectiveness of appointments would be extremely helpful.

7. There is a need to discover expatriate teacher turnover rates compared by privately owned, corporation owned and not-for-profit/trust schools.

8. There is a need to dissect the causal factor of Administrative leadership, to more fully understand what teachers are looking for in the areas of support, 
communication and involvement in decision making. Perhaps a qualitative study focusing on these leadership factors would help in this area.

9. There is a need to replicate this study, using a different population of expatriate teachers, to see how the results would compare.

10. There is a need to study the impact of teacher turnover in international schools on student achievement in those schools.

\section{Summary}

This study has focused on the issue of expatriate teacher turnover in international schools. While the data substantiating this as a problem in international schools are not as powerful or complete as those which describe the issue for US schools, it is nonetheless recognized as an issue among international schools as well (Cambridge, 1998; Fink, 2001; Gillies, 2001). Because of the independent nature of international schools, the capacity to track teacher movement from school to school is severely limited. As such, some of the traditional methods employed in US studies for examining teacher turnover are not possible in the international scene. Thus it is that this study sought to understand this phenomenon from the perspective of what departing expatriate teachers had to say about the schools they left. The findings offered and explained above will hopefully contribute to international school administrators' understanding of and ability to address and manage the issue of teacher turnover in their schools.

While this study has focused virtually exclusively on the welfare of teachers, and sought their opinion on how it can be enhanced to promote greater longevity in international schools, the most fundamental purpose of schools should be returned to in the conclusion of this study. Schools are about students, and as Hardman (2001) pointed 
out, international schools often serve as a haven of security and stability for their students. Any plan to enhance the effectiveness of a school's teaching faculty by addressing the issues that push them away from the school is certain to have a positive impact on that school's students as well. In fact, while this study has revealed that there are issues that must be addressed by international school administrators, it has also offered some gems to celebrate. Embedded in the findings of this study, hidden among the causal factors that were dismissed because they were not deemed to be "key causal factors" is a quality of international schools that should be celebrated. At the very bottom of the list of mean rank values is the causal statement, "Student behavior at the school was influential in my decision to leave the school." The 281 teachers who participated in this study viewed that as the least influential in their decision to leave the school. Compare that against the study that found student discipline to be a frequent source of job dissatisfaction leading to departure from the school (Ingersoll, 2001)! Truly, international educators are blessed to work with wonderfully diverse, inquisitive and open-minded students. It is for their ultimate welfare that this study sought to identify administratively mutable variables that will help reduce expatriate teacher turnover in international schools. 
References 
Blandford, S., \& Shaw, M. (2001). The nature of international school leadership. In S. Blandford \& M. Shaw (Eds.), Managing international schools. London: RoutledgeFalmer.

Buckley, J., Schneider, M., \& Shang, Y. (2005). Fix it and they might stay: School facility quality and teacher retention in Washington, D.C. Teachers College Record, 107(5), $1107-1123$.

Cambridge, J. (1998). Investigating national and organizational cultures in the context of the international school. In M. Hayden \& J. Thompson (Eds.), International Education: Principles and Practice (pp. 197-211). London: Kogan Page.

Cambridge, J. (2002). Recruitment and deployment of staff: A dimension of international school organization. In M. Hayden, J. Thompson \& G. Walker (Eds.), International Education in Practice: Dimensions for national and international schools (pp. 158 - 169). London: Routledge Falmer.

Canterford, G. (2003). Segmented labour markets in international schools. Journal of Research in International Education, 2(1), 47 - 65.

The cost of teacher turnover. (2000).). Austin, Texas: Texas Center for Educational Research, Texas State Board for Educator Certification.

Cost of Turnover Worksheet. (2007).): US Department of Labor.

Council of International Schools - Teacher Recruitment Services webpage. (2007). Retrieved March 24, 2007, from http://www.cois.org/recruitment/jobs.htm Creswell, J. W. (2007). Educational research: Planning, conducting, and evaluating quantitative and qualitative research (3rd ed.): Prentice Hall. 
Darling-Hammond, L. (2003). Keeping good teachers: Why it matters, what leaders can do. Educational Leadership, 60(8), 6-13.

Davis, M. S. (2002). An investigation of factors related to teacher retention in small rural school districts in Montana. Unpublished doctoral dissertation, Montana State University, Bozeman, Montana.

Eberhard, J., Reinhardt-Mondragon, P., \& Stottlemyer, B. (2000). Strategies for new teacher retention: Creating a climate of authentic professional development for teachers with three or less years of experience. Corpus Christi: The South Texas Research and Development Center.

Elfers, A. M., Plecki, M. L., \& Knapp, M. S. (2006). Teacher mobility: Looking more closely at "the movers" within a state system. Peabody Journal of Education, $81(3), 94-127$.

Falch, T., \& Ronning, M. (2005). The influence of student achievement on teacher turnover (CESifo Working Paper No. 1469): Center for Economic Studies (CES), the Ifo Institute for Economic Research and the CESifo GmbH (Munich Society for the Promotion of Economic Research).

Falch, T., \& Strom, B. (2002). Teacher turnover and non-pecuniary factors. Dragvoll: Norwegian Research Council.

Fink, D. (2001). Learning to change and changing to learn. In S. Blandford \& M. Shaw (Eds.), Managing International Schools. London: RoutledgeFalmer.

Fleeter, H., \& Driscoll, W. (2002). Preliminary analysis of Ohio's labor market for teachers and other education professionals. Columbus: Ohio State Board of Education. 
Garton, B. (2000). Recruitment of teachers for international education. In M. Hayden \& J. Thompson (Eds.), International schools \& international education. London: Kogan Page Limited.

George, D., \& Mallery, P. (2003). SPSS for windows step by step: A simple guide and reference (Fourth ed.). Boston: Pearson Education, Inc.

Gillies, W. D. (2001). American international schools: Poised for the twenty-first century. Education, 122(2), 395-401.

Guarino, C. M., Santibanez, L., \& Daley, G. A. (2006). Teacher recruitment and retention: A review of the recent empirical literature. Review of Educational Research, 76(2), $173-208$.

Hansen, M. L., Lien, D. S., Cavalluzzo, L. C., \& Wenger, J. W. (2004). Relative pay and teacher retention: An empirical analysis in a large urban district (No. (IPR) 11022). Alexandria: The CNA Corporation.

Hanushek, E. (2004). The revolving door. Education Next. Retrieved February 19, 2007, from http://www.hoover.org/publications/ednext/3345156.html

Hanushek, E. A., Kain, J. F., \& Rivkin, S. G. (2001). Why public schools lose teachers: Packard Humanities Institute and the Smith Richardson Foundation.

Hanushek, E. A., Kain, J. F., \& Rivkin, S. G. (2004). Why public schools lose teachers. Journal of Human Resources, 39(2), 326-354.

Hardman, J. (2001). Improving recruitment and retention of quality overseas teachers. In S. Blandford \& M. Shaw (Eds.), Managing International Schools. London: RoutledgeFalmer. 
Harris, D. N., \& Adams, S. J. (2007). Understanding the level and causes of teacher turnover: A comparison with other professions. Economics of Education Review, 26(3), $325-337$.

Hawley, D. B. (1994). How long do international school heads survive? A research analysis (Part I). International Schools Journal, XIV(1), 8 - 21.

Hawley, D. B. (1995). How long do international school heads survive? A research analysis (Part II). International Schools Journal, XIV(2), 23 - 36.

Hayden, M. (2006). Introduction to international education: International schools and their communities. London: Sage Publications.

Hayden, M., Rancic, B. A., \& Thompson, J. J. (2000). Being international: student and teacher perceptions from international schools. Oxford Review of Education, 26(1), $107-123$.

Hayden, M., \& Thompson, J. (1998). International education: Perceptions of teachers in international schools. International Review of Education, 44(5/6), 549 - 568.

Henley, J. (2006). E/CIS annual statistical survey 2006: Data summary: European Council of International Schools and Council of International Schools.

Hinkle, D. E., Wiersma, W., \& Jurs, S. G. (2003). Applied statistics for the behavioral sciences (Fifth ed.). Boston: Houghton Mifflin Company.

Hunt, J. B., \& Carroll, T. G. (2003). No dream denied: A pledge to america's children. Washington, D.C.: National Commission on Teaching and America's Future.

Imazeki, J. (2002). Teacher attrition and mobility in urban districts: Evidence from Wisconsin. In J. K. Rice \& C. Roelke (Eds.), Fiscal Issues in Urban Schools (Vol. 1, pp. 119-136). Greenwich, CT: Information Age Publishing Inc. 
Ingersoll, R. M. (2001). Teacher turnover and teacher shortages: An organizational analysis. American Educational Research Journal, 38(3), 499 - 534.

Ingersoll, R. M. (2003). Is there really a teacher shortage? (Document R-03-4): Center for the Study of Teaching and Policy (CTP) and The Consortium for Policy Research in Education (CPRE).

Ingersoll, R. M., \& Smith, T. M. (2003). The wrong solution to the teacher shortage. Educational Leadership, 60(8), 30 - 33.

Ingersoll, R. M., \& Smith, T. M. (2004). Do teacher induction and mentoring matter? National Association of Secondary School Principals, 88(638), 28 - 40.

International Baccalaureate Organization website. (2007). Retrieved March 17, 2007, from http://www.ibo.org/

Johnson, S. M., \& Birkeland, S. E. (2003). The schools that teachers choose. Educational Leadership, 60(8), 20-24.

Joslin, P. (2002). Teacher relocation: Reflections in the context of international schools. Journal of Research in International Education, 1(1), 33 - 62.

Kersaint, G., Lewis, J., Potter, R., \& Meisels, G. (2007). Why teachers leave: Factors that influence retention and resignation. Teaching and Teacher Education, 23, 775 794.

Knapp, R. (2001). The implications of a two-tier salary scale on teacher relations: A case study. International Schools Journal, XXI(1), 57 - 68.

Krei, M. S. (2000). Teacher transfer policy and the implications for equity in urban school districts. Paper presented at the Annual Meeting of the American Educational Research Association, New Orleans, LA. 
Leedy, P. D., \& Ormrod, J. E. (2005). Practical research: Planning and design (8th ed.). Upper Saddle River, NJ: Pearson.

Luekens, M. T., Lyter, D. M., \& Fox, E. E. (2004). Teacher attrition and mobility: Results from the teacher follow-up survey, 2000-01 (No. NCES 2004-301). Washington, D.C.: U.S. Department of Education, National Center for Education Statistics.

McCreight, C. (2000). Teacher attrition, shortage, and strategies for teacher retention: Texas A \& M University.

McKenzie, M. (1998). Going, going, gone...global! In M. Hayden \& J. Thompson (Eds.), International Education: Principles and Practice. London: Kogan Page.

Morice, L. C., \& Murray, J. E. (2003). Compensation and teacher retention: A success story. Educational Leadership, 60(8), 40-43.

Nagel, D. (2007). Can IT turn around teacher turnover? [Electronic Version]. T.H.E. Journal. Retrieved October 20, 2007 from http://www.thejournal.com/articles/20900.

Norton, M. S. (1999). Teacher retention: Reducing costly teacher turnover. Contemporary Education, 70(3), 52 - 55.

Ortloff, W. G., \& Escobar-Ortloff, L. M. (2001). Professional development needs of American international schools overseas: An opportunity for service. Paper presented at the Southern Regional Council on Educational Administration, Jacksonville, FL.

Patton, M. Q. (2002). Qualitative research and evaluation methods, 3rd edition. Thousand Oaks, CA: Sage. 
Powell, W. (2001). Orchids in the bathroom: Reflections on relocation stress. International Schools Journal, XXI(1), 19 - 34.

Punch, K. F. (1998). Introduction to social research: quantitative and qualitative approaches. London: Sage.

Rhodes, C., Nevill, A., \& Allan, J. (2004). Valuing and supporting teachers: A survey of teacher satisfaction, dissatisfaction, morale and retention in an English local education authority. Research in Education(71), 67 - 80.

Richards, N. (1998). The emporer's new clothes? The issue of staffing in international schools. In M. Hayden \& J. Thompson (Eds.), International Education: Principles and Practice (pp. 173-183). London: Kogan Page.

Ritchie, G. (2004). Quantifying the effects of teacher movements between schools in New Zealand: To schools that hath, shall be given. Journal of Education Policy, $19(1), 57-79$.

Ross, S. M., Stringfield, S., Sanders, W. L., \& Wright, S. P. (2003). Inside systemic elementary school reform: Teacher effects and teacher mobility. School Effectiveness and School Improvement, 14(1), 73 - 110.

Santiago, P. (2002). Teacher demand and supply: Improving teaching quality and addressing teacher shortages: OECD Education Working Paper No. 1.

Sargent, T., \& Hannum, E. (2005). Keeping teachers happy: Job satisfaction among primary school teachers in rural northwest China. Comparative Education Review, 49(2), 173 - 204. 
Scafidi, B., Sjoquist, D. L., \& Stinebrickner, T. R. The relationship between school characteristics and teacher mobility: Georgia State University and University of Western Ontario.

Skinner, K. J. (1998). Navigating the legal and ethical world of overseas contracts. International Schools Journal, XVII(2), 60 - 67.

Stinebrickner, T. R. (2001). A dynamic model of teacher labor supply. Journal of Labor Economics, 19(1), $196-230$.

Stirzaker, R. (2004). Staff induction: Issues surrounding induction into international schools. Journal of Research in International Education, 3(1), 31 - 49.

Teachers matter: Attracting, developing and retaining effective teachers. (2005).): OECD Education and Training Policy.

Thearle, C. (2000). The role of women in senior management in international schools. In M. Hayden \& J. Thompson (Eds.), International schools and international education. London: Kogan Page Limited.

Thornton, B., Peltier, G., \& Medina, R. (2007). Reducing the special education teacher shortage. The Clearing House, 80(5), 233 - 238.

Vidal, J., \& Xu, M. (1992). Student and teacher mobility: Impact on school performance in New York city public schools. New York: Office for Planning, Research and Support Services, The State Education Department, The University of the State of New York.

Ware, H., \& Kitsantas, A. (2007). Teacher and collective efficacy beliefs as predictors of professional commitment. The Journal of Educational Research, 100(5), 303 310. 
Webb, R., Vulliamy, G., Hamalainen, S., Sarja, A., Kimonen, E., \& Nevalainen, R. (2004). Pressures, rewards and teacher retention: A comparative study of primary teaching in England and Finland. Scandinavian Journal of Educational Research, $48(2), 169-188$.

Williams, J. (2003). Why great teachers stay. Educational Leadership, 60(8), 71-74. 
Teacher Turnover in International Schools

Appendix A: Letter of Invitation 


\section{Date}

Dear Fellow International Educator:

I am a doctoral student in the Educational Administration Department at the College of Education and Human Services, Seton Hall University.

I am also an administrator in an international school, and I am currently conducting research into teacher turnover in international schools. Specifically, I would like to know why expatriate teachers often choose to leave an international school at the end of their first contract with that school. (For the purposes of this study, I have defined expatriate as someone who is living in a country of which they are not a citizen.) If you fit that profile, I would like to invite you to participate in this study. Your honest feedback about the reasons why you chose to leave the school will be a valuable source of information about how administrators can address issues that contribute to high teacher turnover in international schools. Again, this study is designed to collect data only from expatriate teachers who have left an international school at the end of their first contract with that school. If you have done so, regardless of how long ago that was, I would ask that you complete the questionnaire available at the link you will find at the bottom of this letter.

This survey is being conducted entirely online, using a survey tool called ASSET (Academic Survey System and Evaluation Tool). It was designed by a professor at Seton Hall University, and has been used many times for research of this nature. The questionnaire is comprised of 36 questions, and should take about 15 minutes of your time. The questionnaire is entitled "Expatriate Teacher Turnover" and is designed to collect some general information about you, some information about the school you left, and most importantly some specific information about factors that were influential in your decision to leave.

Your decision to participate in this survey is entirely voluntary. By clicking on the link below and completing the questionnaire, you indicate your informed consent and your willingness to participate.

Your participation in this survey will be entirely anonymous. No information will be collected that will allow for your identity to be discerned.

As the questionnaires are completed, data housed on the Seton Hall servers will be downloaded by the researcher and stored on a USB memory key, which will be further stored in a locked filing cabinet in the researcher's office. Only the researcher will have access to the research records.

There are no anticipated risks to participating in this survey. However, there are potential benefits. The results of this study will be made available to administrators in international schools around the world, in the hope that whatever factors have hastened the departure of teachers from our schools can be rectified. Your candid feedback will be of great usefulness in this process. 
This study has passed the approval of the Seton Hall Institutional Review Board (IRB). Any questions regarding the study may be directed either to the researcher or to the IRB. The researcher can be reached at (65) 64671732 or by email at odlandgl@ shu.edu. The IRB can be reached at (973) 313-6314 or by email at irb@ shu.edu.

Thank you very much for your participation in this study. You may now access the questionnaire by clicking on the following link. (Insert URL for questionnaire)

Sincerely,

Glenn Odland

Doctoral Candidate, Seton Hall University 
Appendix B: Survey Instrument 


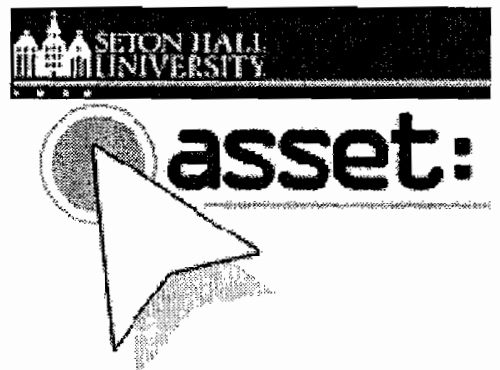

\section{QCADEMIC SURVEY SYSTEM \& EVALUATION TOOL}

Tiew Sumary Crosstabs Detals Export Buld

\section{Expatriate Teacher Turnover in International Schools}

This survey is designed only for expatriate teachers who have at some point in their career left an intemational school at the end of their first contract with that school.

Please answer all questions as you would have in the year in which you left the school referred to above.

Section I Teacher Profile

1. Including the year in which you left, how many total years of teaching experience did vou have at IHA T OR ANY OTHER school?

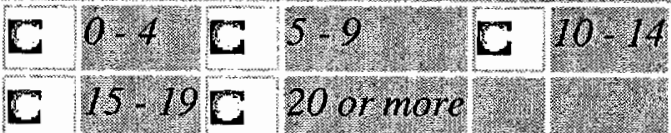

2. Including the year in which you left, how many years had you been at THAT school?

C $/ \mathrm{C} / \mathrm{2}] \overline{3}$

C 4 (3)

3. Including the year in which you left, how many years had you taught at international schools?
C $0.4 \cdot \mathrm{E}$
C $15.19 \mathrm{C}$

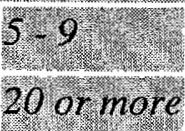
C $\longdiv { 1 0 } \cdot 1 4$ 


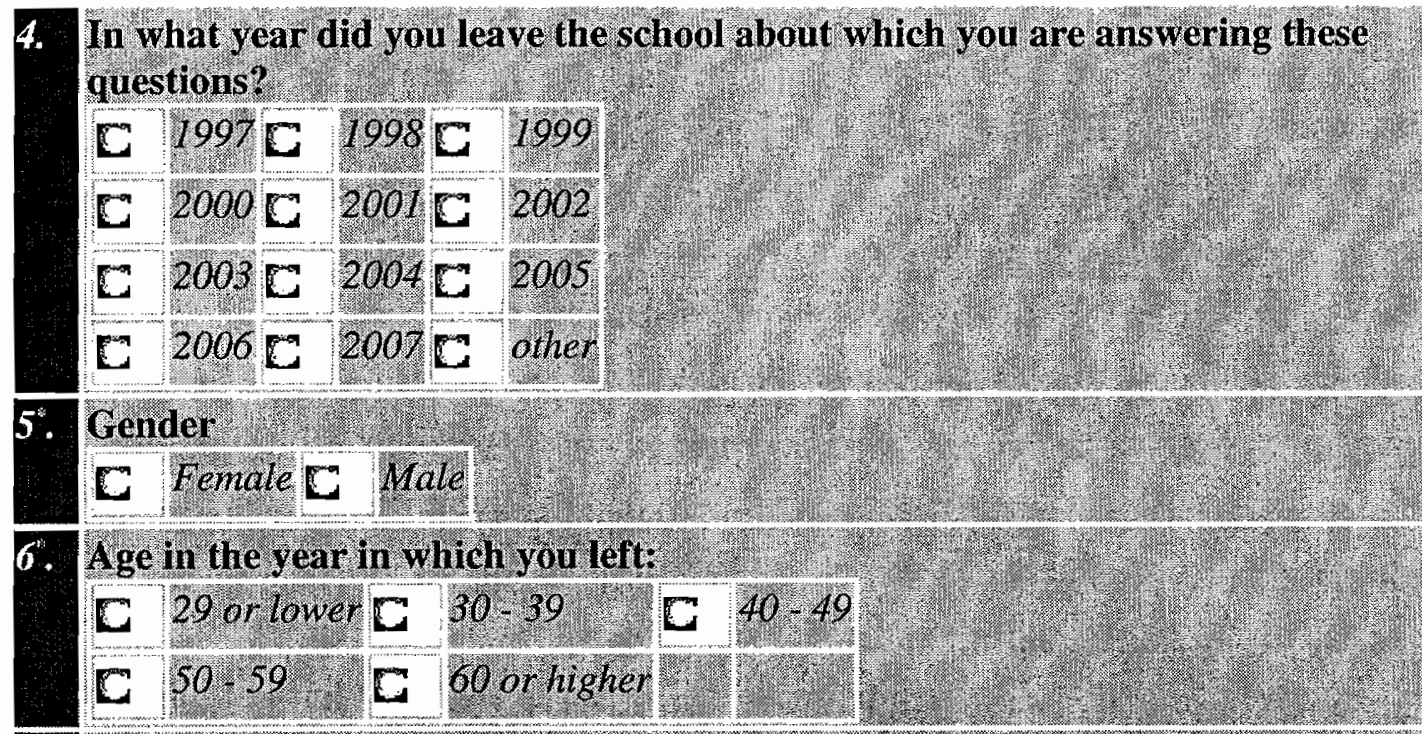

7. Marital Status in the year in which you left:

E Single $\mathrm{C}$ Married

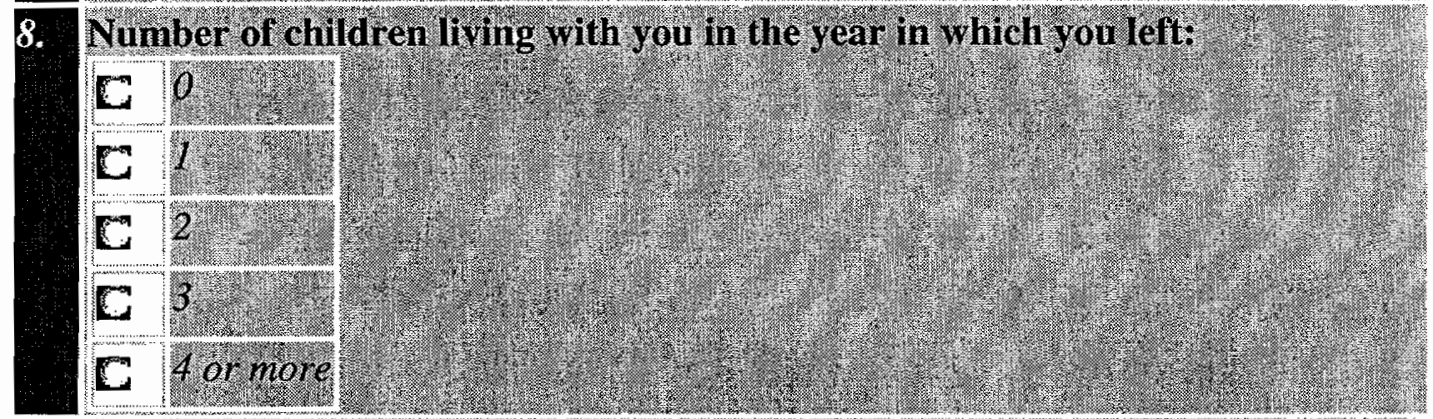

9. Highest legree you had earned in the year in which you left?
C Bachewrs
C Master:s:
E Specialist or professional diploma
Ca Doctorate or profeswional degree

10. Teaching certificates/credentials held in the year in which youl left, dates acquired, and issuing countrylorganization:

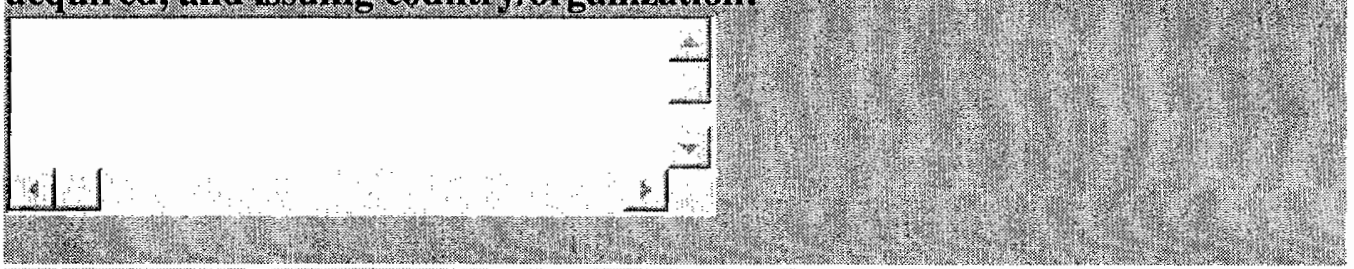

11. Main subject area of teaching:
C.Elementary
C Mathiscience
C Humanities

Lexoun generalist 


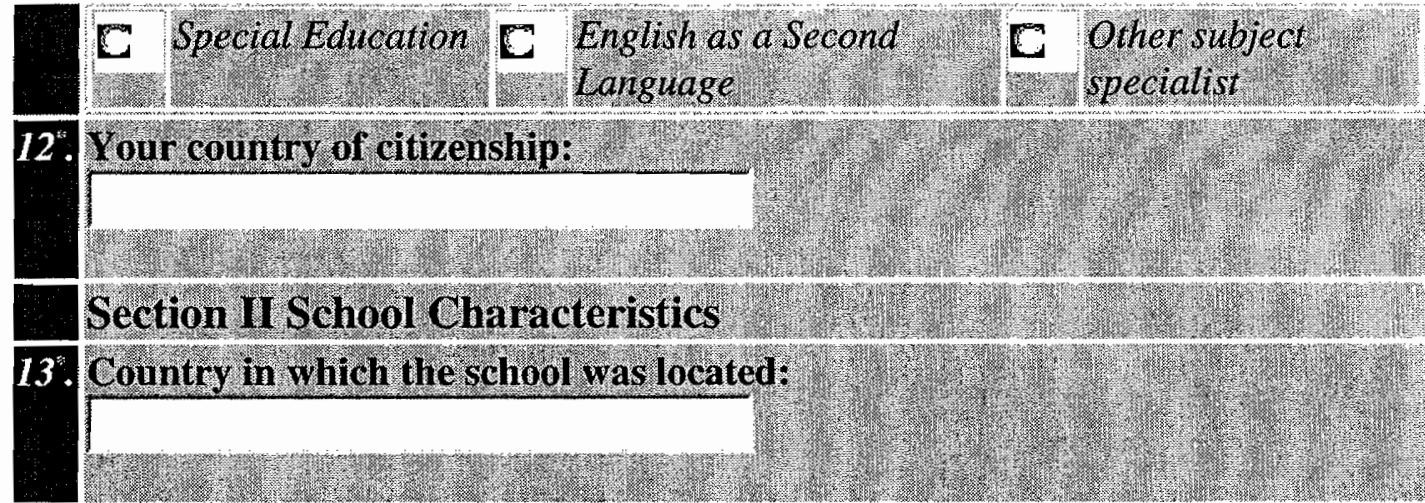

14. How many students were en olled in the school?
C 11.99
C $100 \cdot 249$
$250-509$

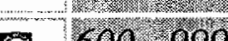
C $600=999$
C $/ 000$ orabove

15. Indicate all of the following programs that were offered at the school by clicking the corresponding box(es).

F Cambridge intertiational Ixamination Program (CIE)

( Advanced Placerient (AP)

T MPrinary Tears Programme (PYP)

r IB Madle Years Programme (MVP)

r. IB Diploma Programme (DP)

r. National curriculum from 20:0

16. In which category did your school fit?
E Norforprofithust
E Privalely owned
C Mulrinational comoration owned

SectionIII Reasoins for leaving the school

Please indicate your level of agreement with each of the following statements.

\begin{tabular}{|c|c|c|c|c|c|}
\hline 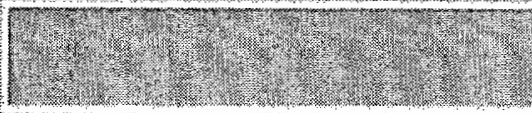 & $\begin{array}{l}\text { Strongly } \\
\text { agree }\end{array}$ & Agree & Undecided & Wisagree & $\begin{array}{l}\text { Strongly } \\
\text { disagree }\end{array}$ \\
\hline $\begin{array}{l}\text { A. The level of support from the } \\
\text { princtpat and senior }\end{array}$ & 15 & 5 & $\sqrt{6}$ & C & $r^{m}$ \\
\hline
\end{tabular}


managenent at the school was influential in my decision to heave the school.

B. The quality of the induction program was influential in my dectsion to leave the school.

C. Resonrce support at the school t technological, print or ohtervise) was influential in my decision to leave the school

D. Student behavior at the school was influential in my decision to teave the school.

E. Parental support of teachers Was influertial in iny decision to leave the school.

F. The quality of the school facily) Was influential in mo decision to leave the school. G. The academic standards of the school were influential in. my decision to leave the school. 1. The stability of my teaching assignment at the school was influential in my decision to leave the school.

1. Expectations regariding teacher worktoad were influential in my decision to Yeave the school:

6. Communication between seniar management and faculty at the school was influentid in my decision to leave the school. $K$. The overall compensation package affered to me was influential in my decision to leave the school.

L. Orportunities for leadership at the school were influential in my decision to leave the school.
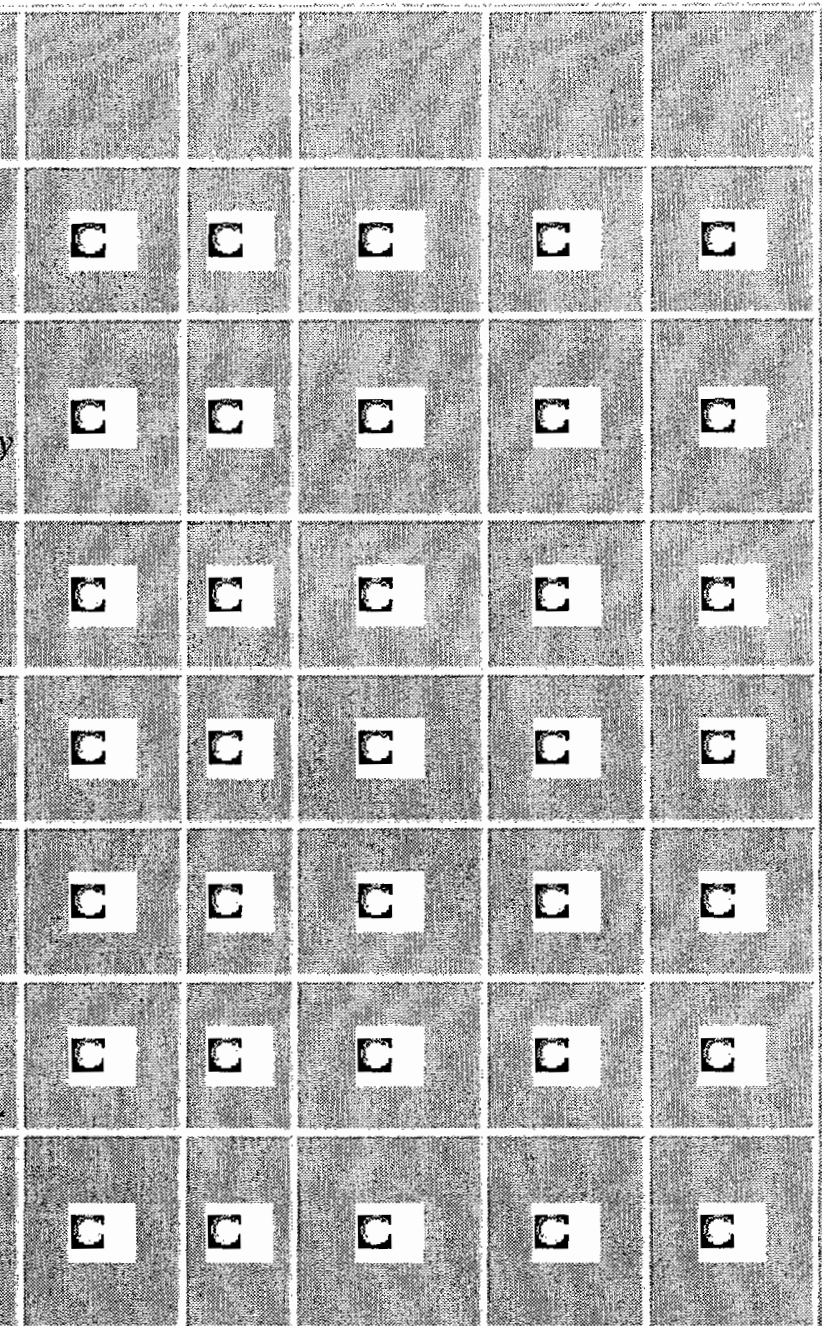

M. Teacher involvement in
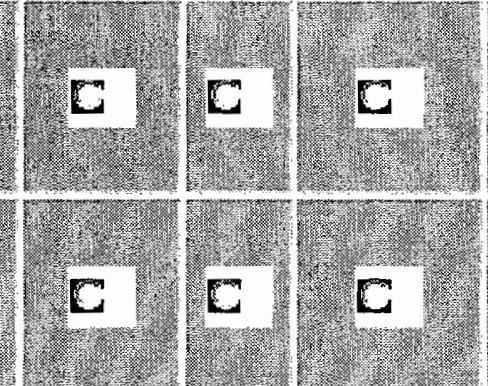

r
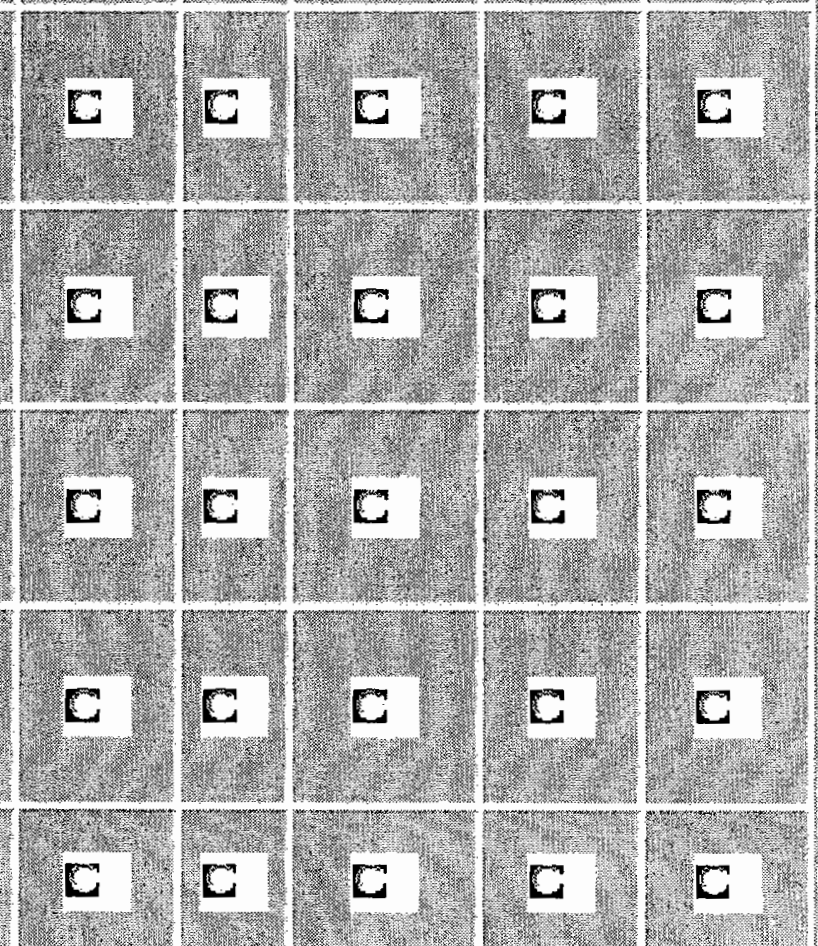

E
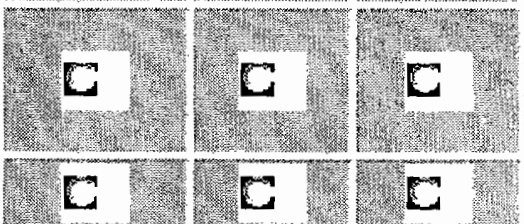


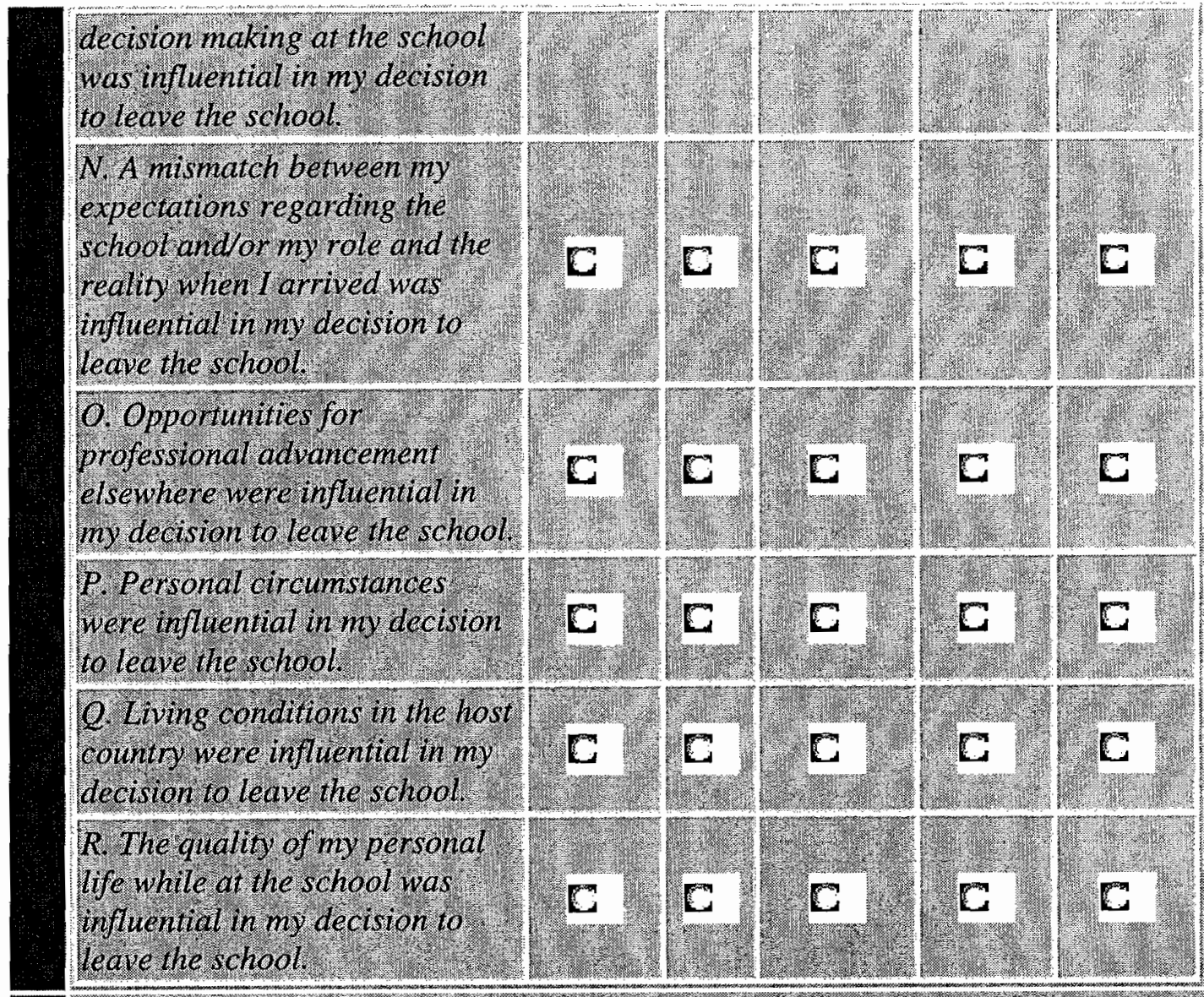

18. Please feel free to add explanatory comments for any of the items in the above question.

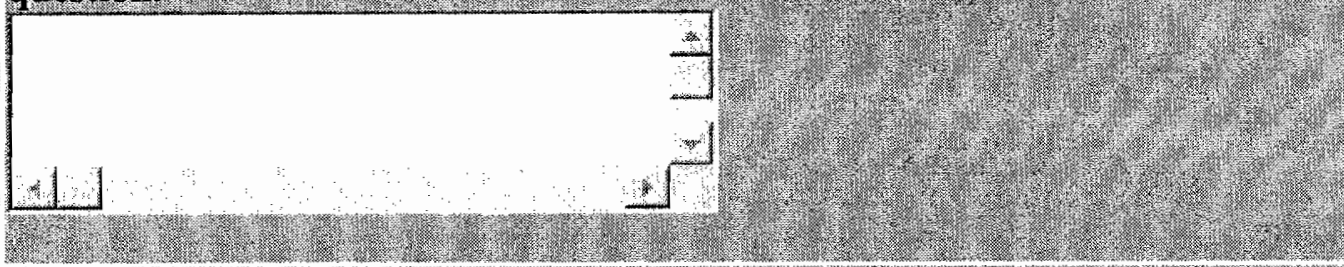

19. What were the top three reasons that prompted you to leave the school?

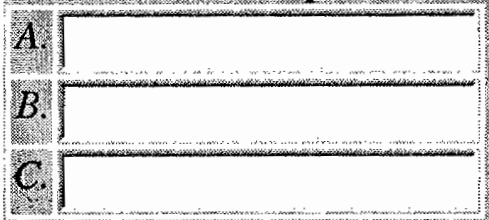

Was there anything the school's administration could have done to prevent you from leaving in that y ear?

E Tes

E No

21. Please explain your answer for the above question (20). 


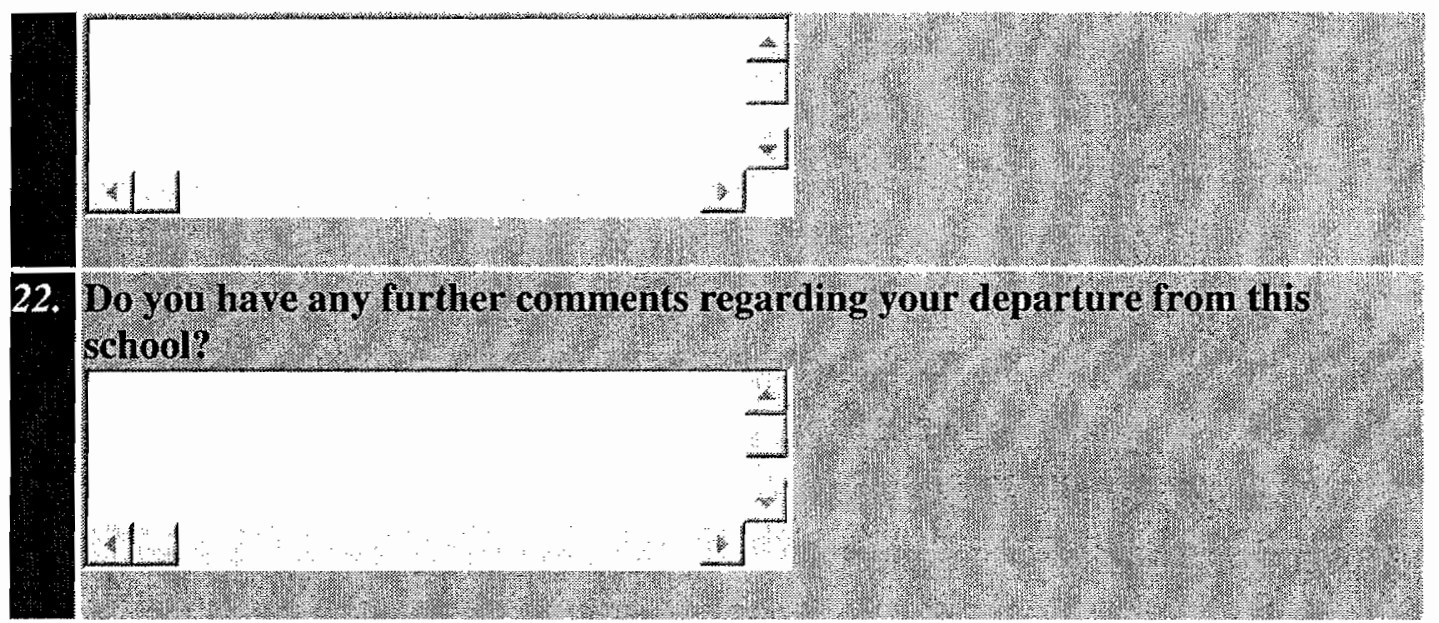

asset 3.Ia - April 2006 Seton Hall University (c) bgw 
Appendix C: Graphs displaying Teacher Characteristics 


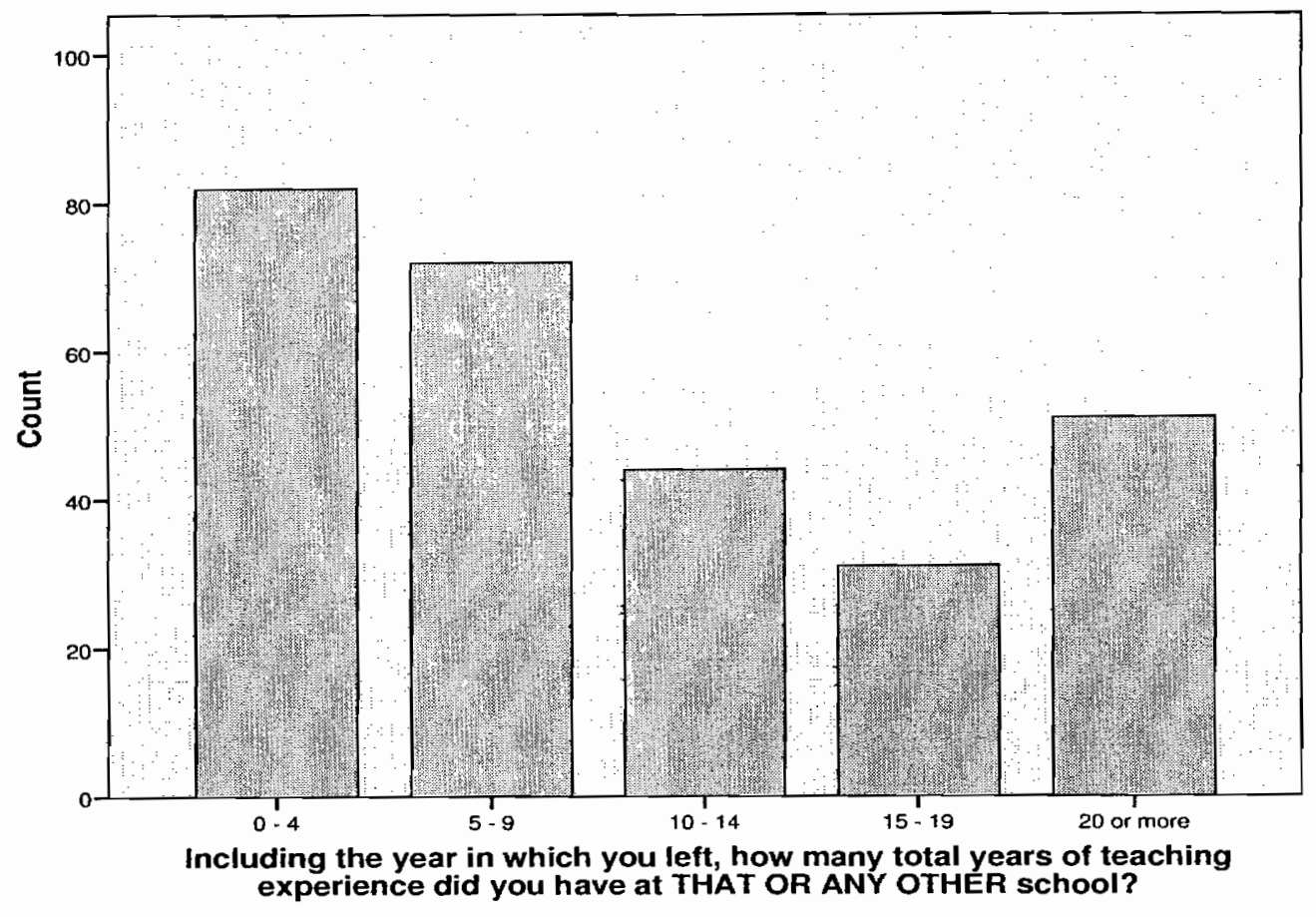

Figure 3. Total years teaching experience.

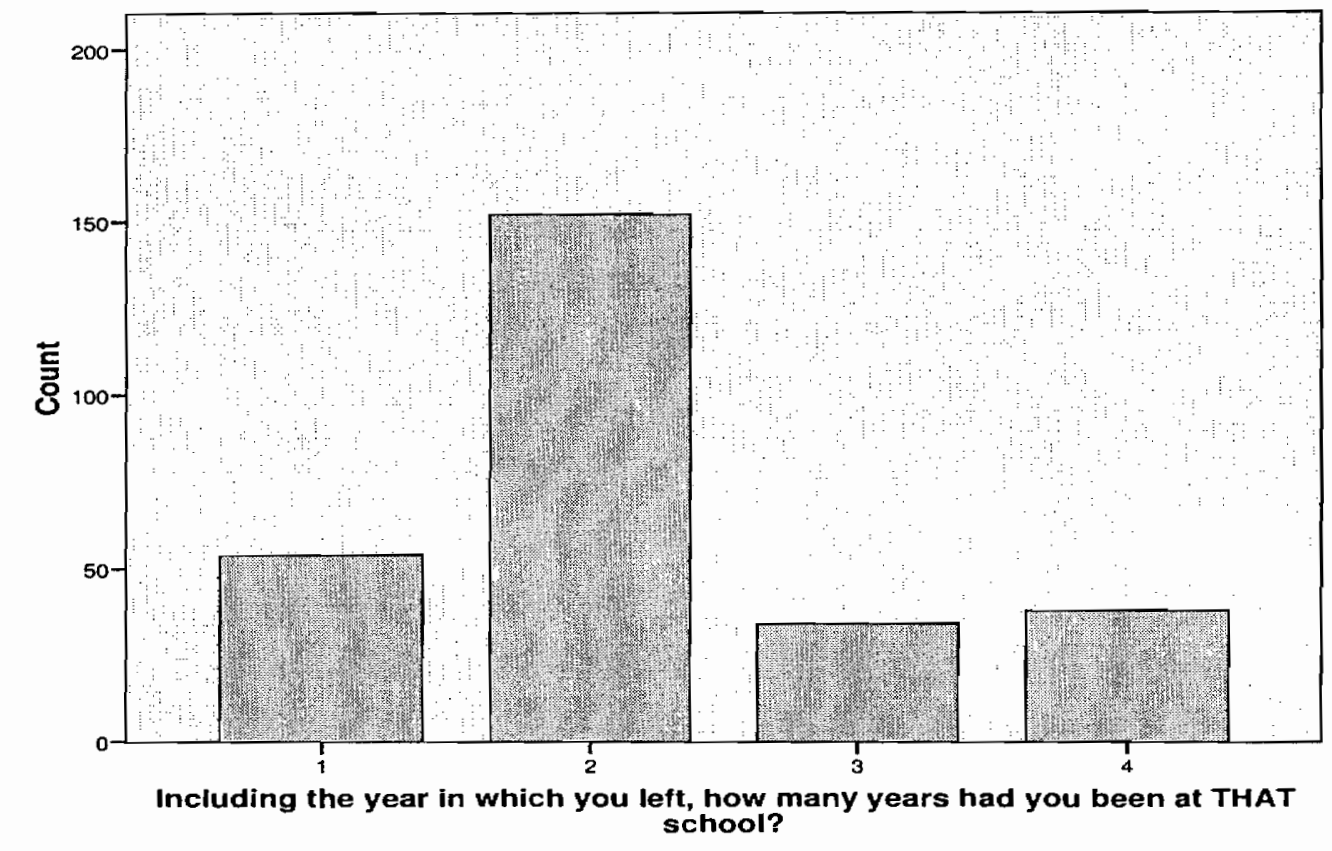

Figure 4. Years at school about which participants responded. 


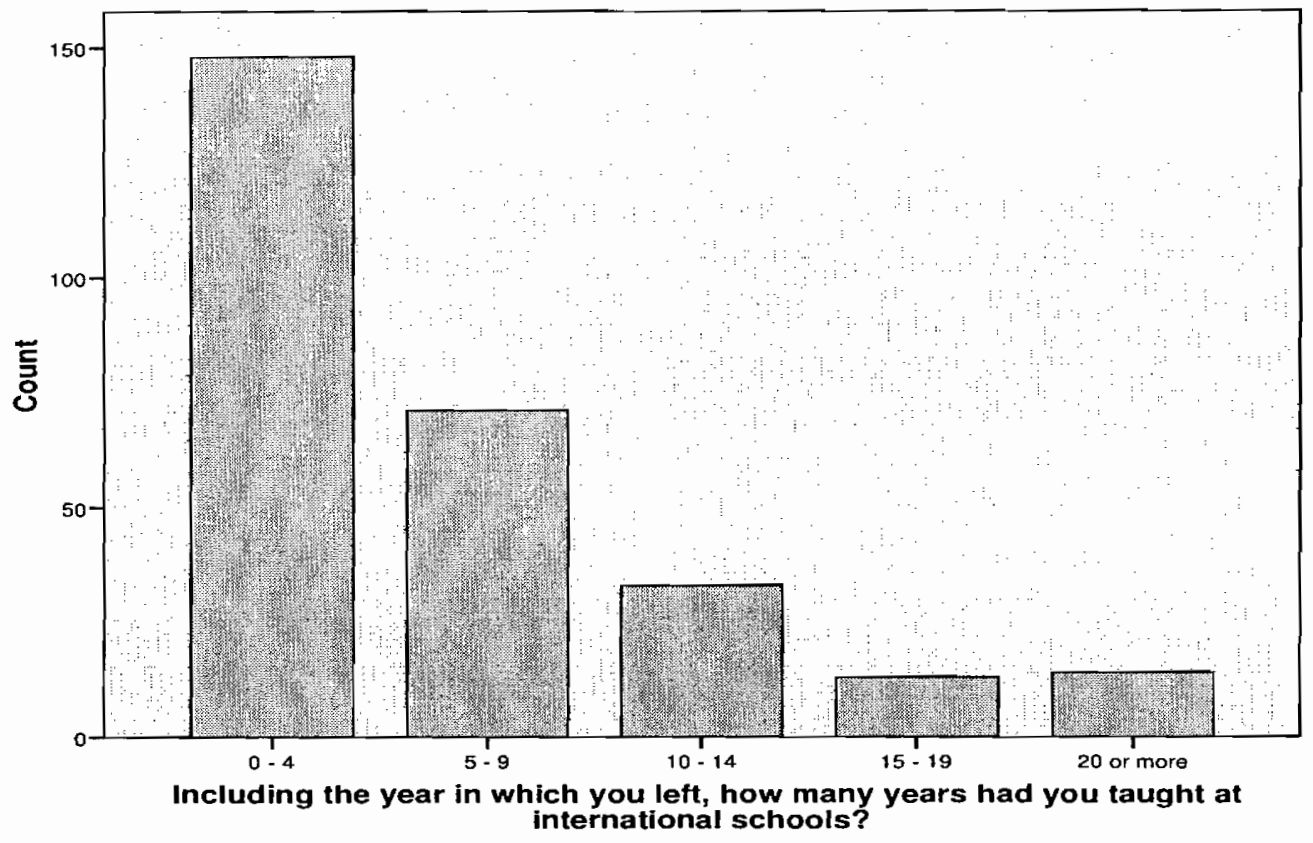

Figure 5. Years at international schools.

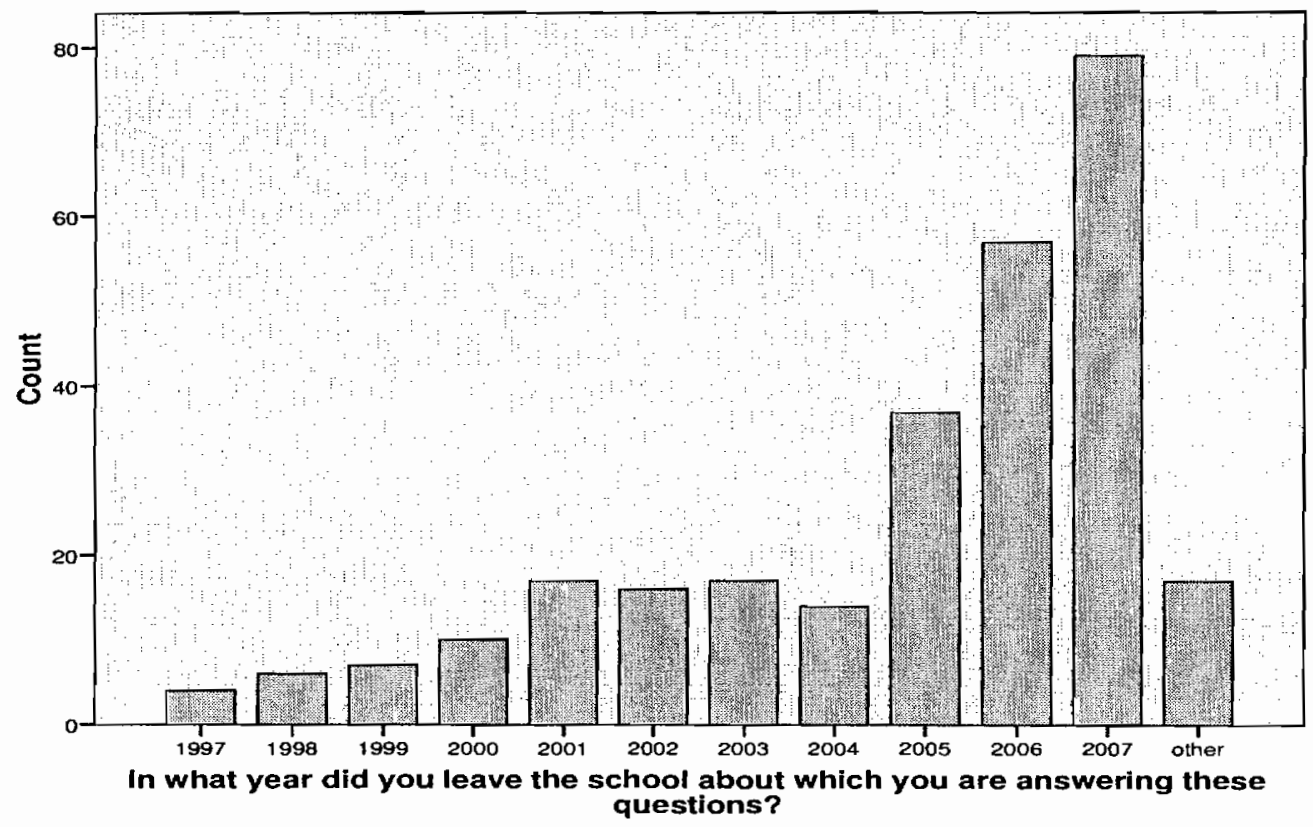

Figure 6. Year in which respondent left the school. 


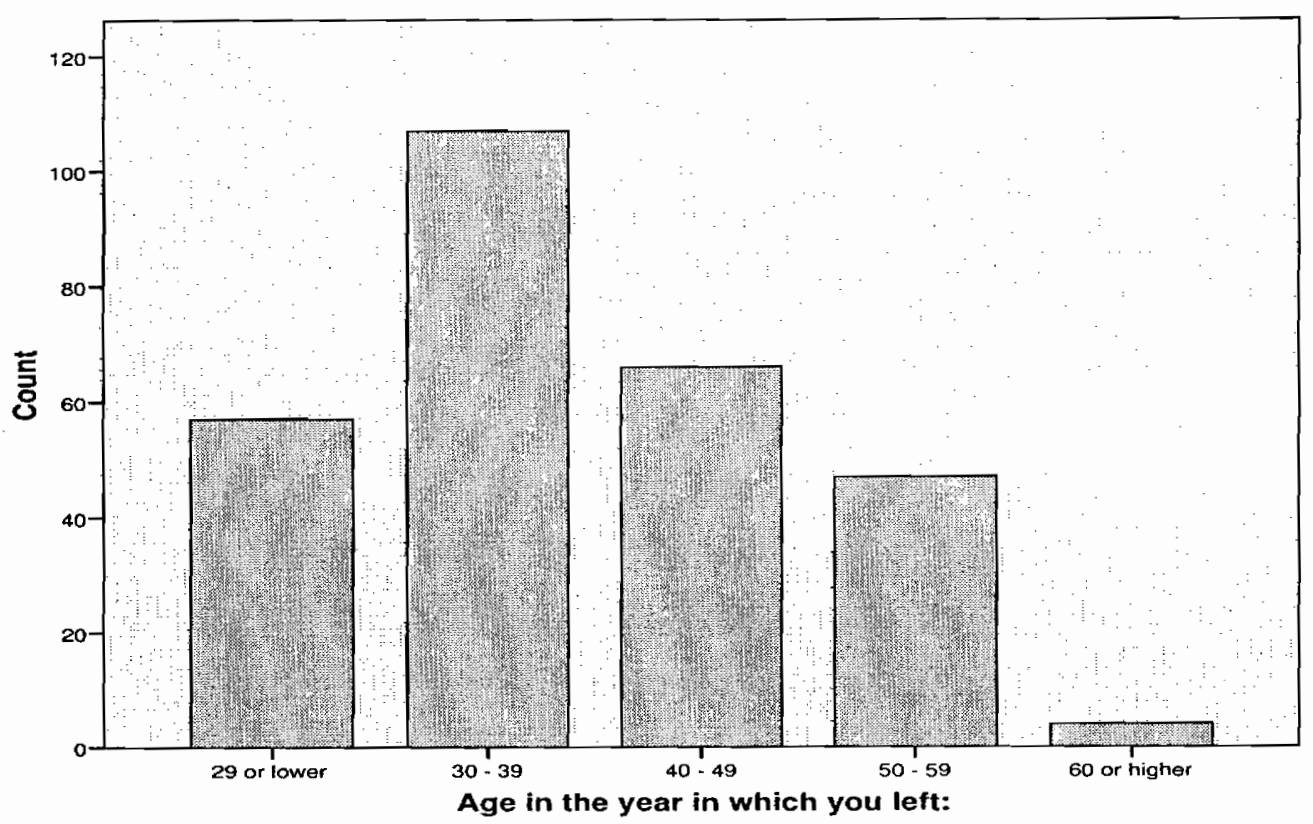

Figure 7. Age of respondent.

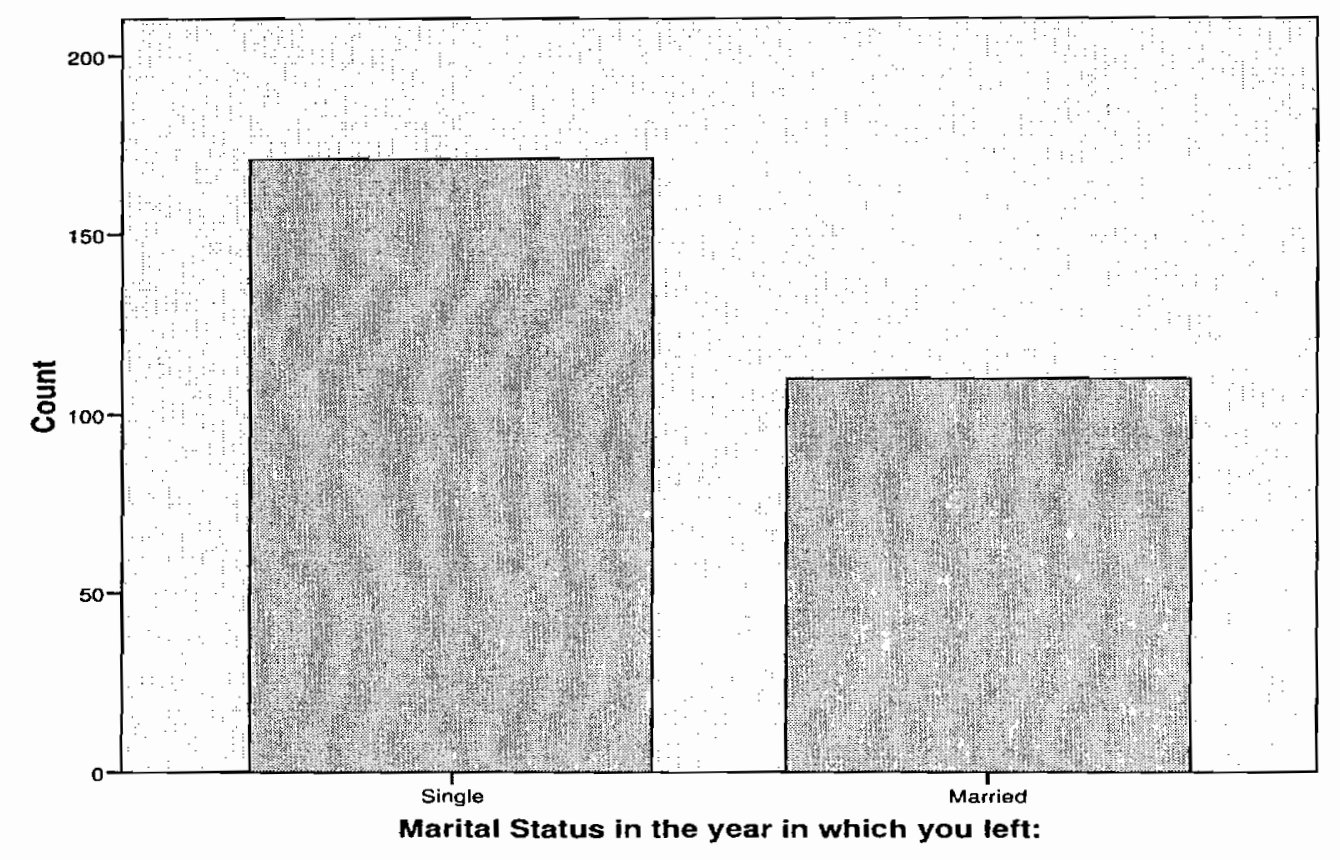

Figure 8. Marital status. 


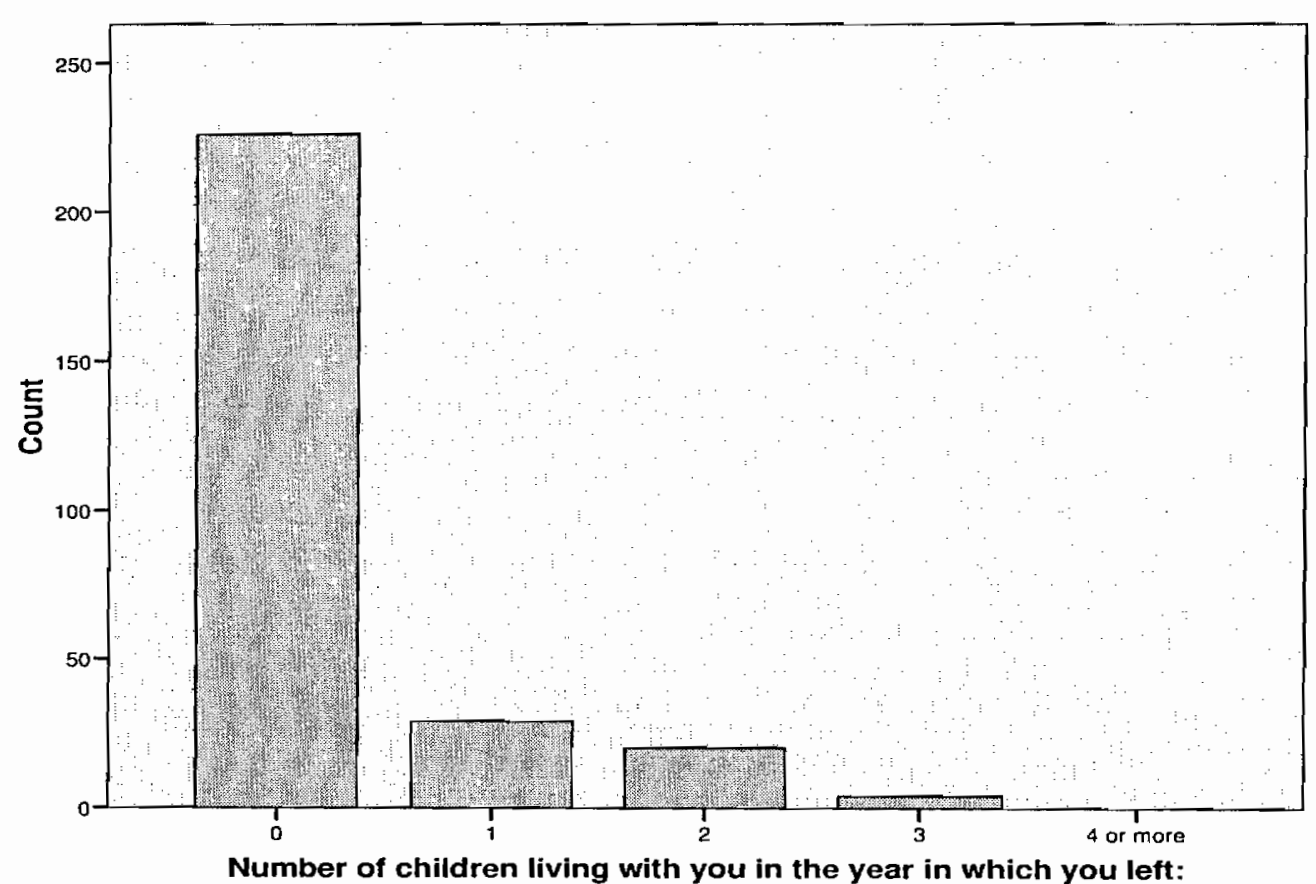

Figure 9. Number of children living with respondent.

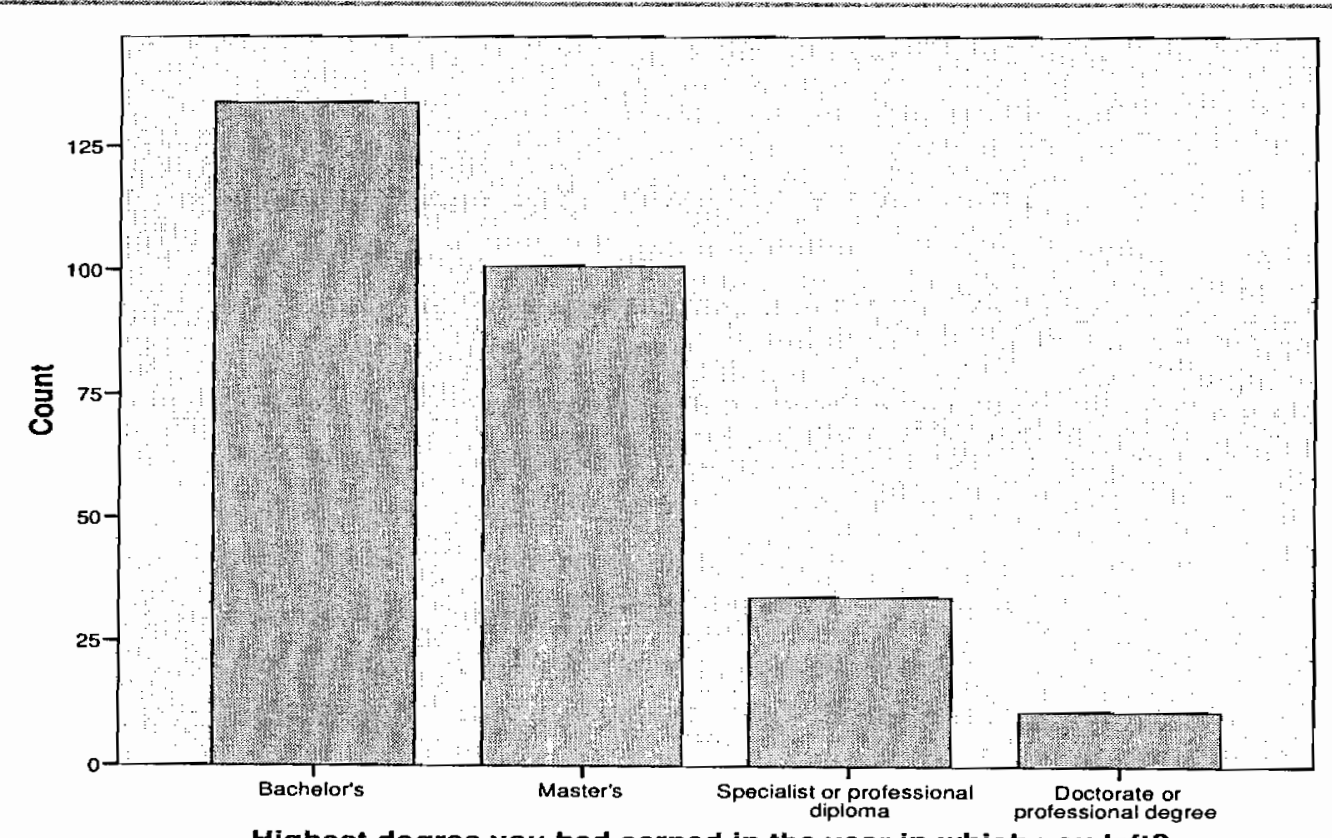

Highest degree you had earned in the year in which you left?

Figure 10. Education level. 


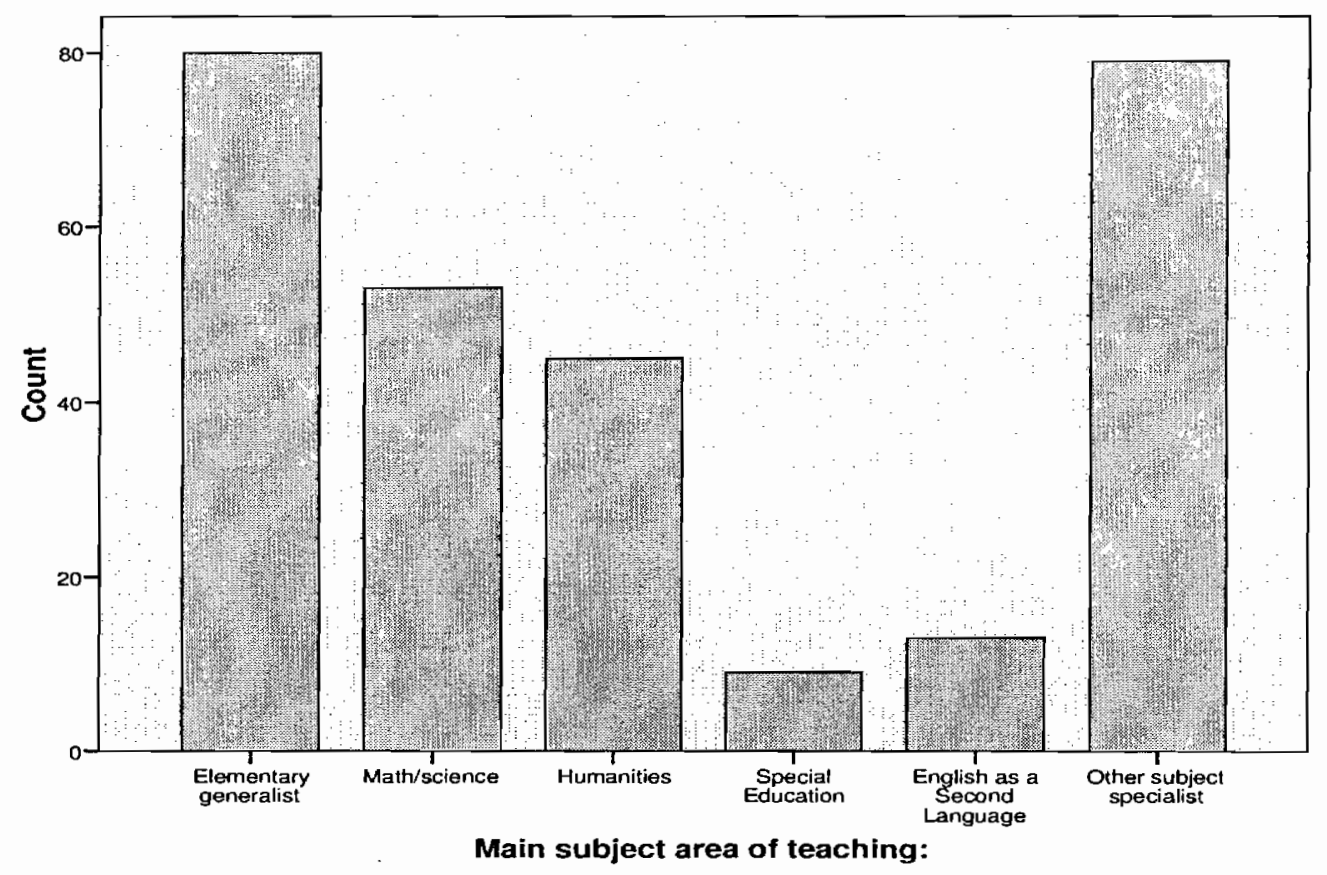

Figure 11. Main subject area of teaching. 
Teacher Turnover in International Schools

Appendix D: Quantitative Analysis Tables 
Mean Ranks by School size

\begin{tabular}{|c|c|c|c|}
\hline \multirow{6}{*}{$\begin{array}{l}\text { A. The level of support from } \\
\text { the principal and senior } \\
\text { management at the school } \\
\text { was influential in my } \\
\text { decision to leave the } \\
\text { school. }\end{array}$} & $\begin{array}{l}\text { How many students were } \\
\text { enrolied in the school? }\end{array}$ & $N$ & Mean Rank \\
\hline & $1-99$ & 9 & 177.17 \\
\hline & $100 \cdot 249$ & 38 & 142.96 \\
\hline & $250-599$ & 108 & 138.77 \\
\hline & $600-999$ & 67 & 147.27 \\
\hline & 1000 or above & 55 & 120.39 \\
\hline \multirow{5}{*}{$\begin{array}{l}\text { B. The quality of the } \\
\text { induction program was } \\
\text { influential in my decision to } \\
\text { leave the school. }\end{array}$} & Total & 277 & \\
\hline & $1-99$ & 8 & 147.19 \\
\hline & $100-249$ & 38 & 168.01 \\
\hline & $250-599$ & 109 & 132.73 \\
\hline & $600-999$ & 68 & 139.31 \\
\hline \multirow{7}{*}{$\begin{array}{l}\text { C. Resource support at the } \\
\text { school (technological, print } \\
\text { or otherwise) was } \\
\text { influential in my decision to } \\
\text { leave the school. }\end{array}$} & 1000 or above & 55 & 132.34 \\
\hline & Total & 278 & \\
\hline & $1-99$ & 8 & 181.50 \\
\hline & $100-249$ & 38 & 171.34 \\
\hline & $250-599$ & 109 & 137.88 \\
\hline & $600-999$ & 68 & 128.75 \\
\hline & 1000 or above & 55 & 127.90 \\
\hline \multirow{5}{*}{$\begin{array}{l}\text { D. Student behavior at the } \\
\text { school was influential in my } \\
\text { decision to leave the } \\
\text { school. }\end{array}$} & Total & 278 & \\
\hline & $1-99$ & 8 & 122.50 \\
\hline & $100-249$ & 37 & 148.11 \\
\hline & $250-599$ & 109 & 131.28 \\
\hline & $600-999$ & 68 & 146.19 \\
\hline \multirow{7}{*}{$\begin{array}{l}\text { E. Parental support of } \\
\text { teachers was influential in } \\
\text { my decision to leave the } \\
\text { school. }\end{array}$} & 1000 or above & 55 & 141.68 \\
\hline & Total & 277 & \\
\hline & $1-99$ & 9 & 162.72 \\
\hline & $100-249$ & 38 & 145.25 \\
\hline & $250-599$ & 108 & 133.35 \\
\hline & $600-999$ & 68 & 140.06 \\
\hline & 1000 or above & 54 & 140.61 \\
\hline \multirow{8}{*}{$\begin{array}{l}\text { F. The quality of the school } \\
\text { facility was influential in my } \\
\text { decision to leave the } \\
\text { school. }\end{array}$} & Total & 277 & \\
\hline & $1-99$ & 9 & 167.50 \\
\hline & $100-249$ & 38 & 169.28 \\
\hline & $250-599$ & 109 & 138.58 \\
\hline & $600-999$ & 67 & 128.22 \\
\hline & 1000 or above & 55 & 129.91 \\
\hline & Total & & \\
\hline & & 278 & \\
\hline G. The academic standards & $1-99$ & 8 & 139.56 \\
\hline
\end{tabular}


of the school were

influential in my decision to

leave the school.

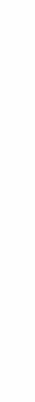

$100-249$

$250-599$

600 - 999

1000 or above

Total

$H$. The stability of my teaching assignment at the school was influential in my decision to leave the school.

I. Expectations regarding teacher workload were influential in my decision to leave the school.

J. Communication between
senior management and
faculty at the school was
influential in my decision to
leave the school.

$K$. The overall compensation package offered to me was influential in my decision to leave the school.

L. Opportunities for
leadership at the school
were influential in my
decision to leave the
school.

$M$. Teacher involvement in decision making at the school was influential in my decision to leave the school.

1- 99

$100-249$

$250-599$

$600-999$

1000 or above

Total

1 - 99

$100-249$

$250-599$

$600-999$

1000 or above

Total

1 - 99

$100-249$

$250-599$

$600-999$

1000 or above

Total

1 - 99

$100-249$

$250-599$

$600-999$

1000 or above

Total

1. 99

$100-249$

$250-599$

$600-999$

1000 or above

Total

1 - 99

$100-249$

$250-599$

$600-999$

1000 or above

Total

N. A mismatch between my expectations regarding the school and/or my role and the reality when I arrived was influential in my decision to leave the school.
1 - 99

$100-249$

$250-599$

$600-999$

1000 or above

Total
167.03

136.65

127.52

138.36

55

277

$9 \quad 210.94$

$38 \quad 153.11$

$109 \quad 133.07$

$68 \quad 136.56$

$55 \quad 137.32$

279

8

129.44

38

109

147.37

135.94

150.05

131.89

279

9

153.17

147.12

136.40

109

152.54

68

121.69

278

8

157.69

159.80

141.09

134.12

123.85

277

8

112.75

38

160.29

108

140.05

137.93

55

127.38

277

9

168.11

156.69

137.06

142.01

125.00

55

278

8

193.69

$\begin{array}{rr}37 & 147.18 \\ 108 & 137.62\end{array}$

$68 \quad 134.06$

$55 \quad 131.86$ 


\begin{tabular}{|c|c|c|c|}
\hline O. Opportunities for & $1-99$ & 8 & 171.63 \\
\hline professional advancement & $100-249$ & 38 & 169.01 \\
\hline in my decision to leave the & $250-599$ & 109 & 132.33 \\
\hline school. & $600-999$ & 68 & 142.03 \\
\hline & 1000 or above & 55 & 125.51 \\
\hline & Total & 278 & \\
\hline P. Personal circumstances & $1-99$ & 8 & 155.75 \\
\hline were influential in my & $100-249$ & 38 & 126.28 \\
\hline $\begin{array}{l}\text { decision to leave the } \\
\text { school }\end{array}$ & $250-599$ & 109 & 141.65 \\
\hline & $600-999$ & 68 & 138.97 \\
\hline & 1000 or above & 55 & 142.66 \\
\hline & Total & 278 & \\
\hline Q. Living conditions in the & $1 \cdot 99$ & 8 & 172.31 \\
\hline host country were & $100-249$ & 38 & 129.99 \\
\hline $\begin{array}{l}\text { influential in my decision to } \\
\text { leave the school. }\end{array}$ & $250-599$ & 109 & 136.16 \\
\hline & $600-999$ & 69 & 143.98 \\
\hline & 1000 or above & 55 & 144.85 \\
\hline & Total & 279 & \\
\hline R. The quality of my & $1-99$ & 9 & 174.89 \\
\hline personal life while at the & $100-249$ & 37 & 121.04 \\
\hline $\begin{array}{l}\text { school was influential in my } \\
\text { decision to leave the }\end{array}$ & $250-599$ & 109 & 142.00 \\
\hline school. & $600-999$ & 69 & 141.54 \\
\hline & 1000 or above & 55 & 141.15 \\
\hline & Total & 279 & \\
\hline
\end{tabular}

Test Statistics by School Size(a,b)

A. The level of support from the principal and senior

Chi-Square management at the school was influential in my decision to leave the school.

$B$. The quality of the induction program was influential in my decision to leave the school.

C. Resource support at the school (technological, print or otherwise) was influential in my decision to leave the school.

D. Student behavior at the school was influential in my decision to leave the school.

E. Parental support of teachers was influential in my decision to leave the school.

$F$. The quality of the school facility was influential in my decision to leave the school.

$\mathrm{G}$. The academic standards of the school were influential in my decision to leave the school. df

Asymp. Sig.

6.330

4

.176

6.585

4

.160

11.259

4

.024

2.850

4

.583

1.756

4

.781

8.986

4

.061

6.659

4

.155 


\begin{tabular}{|c|c|c|c|}
\hline $\begin{array}{l}\text { H. The stability of my teaching assignment at the school } \\
\text { was influential in my decision to leave the school. }\end{array}$ & 9.845 & 4 & .043 \\
\hline $\begin{array}{l}\text { I. Expectations regarding teacher workload were } \\
\text { influential in my decision to leave the school. }\end{array}$ & 2.529 & 4 & .639 \\
\hline $\begin{array}{l}\text { J. Communication between senior management and } \\
\text { faculty at the school was influential in my decision to } \\
\text { leave the school. }\end{array}$ & 5.665 & 4 & .226 \\
\hline $\begin{array}{l}\text { K. The overall compensation package offered to me } \\
\text { was influential in my decision to leave the school. }\end{array}$ & 5.566 & 4 & .234 \\
\hline $\begin{array}{l}\text { L. Opportunities for leadership at the school were } \\
\text { influential in my decision to leave the school. }\end{array}$ & 5.046 & 4 & .283 \\
\hline $\begin{array}{l}\text { M. Teacher involvement in decision making at the } \\
\text { school was influential in my decision to leave the } \\
\text { school. }\end{array}$ & 5.054 & 4 & .282 \\
\hline $\begin{array}{l}\text { N. A mismatch between my expectations regarding the } \\
\text { school and/or my role and the reality when I arrived was } \\
\text { influential in my decision to leave the school. }\end{array}$ & 5.147 & 4 & .273 \\
\hline $\begin{array}{l}\text { O. Opportunities for professional advancement } \\
\text { elsewhere were influential in my decision to leave the } \\
\text { school. }\end{array}$ & 9.484 & 4 & .050 \\
\hline $\begin{array}{l}\text { P. Personal circumstances were influential in my } \\
\text { decision to leave the school. }\end{array}$ & 1.600 & 4 & .809 \\
\hline $\begin{array}{l}\text { Q. Living conditions in the host country were influential } \\
\text { in my decision to leave the school. }\end{array}$ & 2.641 & 4 & .620 \\
\hline $\begin{array}{l}\text { R. The quality of my personal life while at the school } \\
\text { was influential in my decision to leave the school. }\end{array}$ & 4.025 & 4 & .403 \\
\hline
\end{tabular}

\section{Mean Ranks by Perceived academic standard}

\begin{tabular}{llrr} 
& G. The academic & & \\
& $\begin{array}{l}\text { standards of the school } \\
\text { were influential in my } \\
\text { decision to leave the }\end{array}$ & & \\
& school. & & Mean Rank \\
A. The level of support from & Strongly disagree & 100 & 108.32 \\
the principal and senior & Disagree & 20 & 134.39 \\
management at the school & Undecided & 50 & 132.30 \\
was influential in my & Agree & 29 & 159.83 \\
decision to leave the & Strongly agree & 274 & 188.78 \\
school. & Total & 77 & 86.08 \\
& Strongly disagree & 101 & 144.73 \\
B. The quality of the & Disagree & 20 & 167.70 \\
induction program was & Undecided & 50 & 162.61 \\
influential in my decision to & Agree & 29 & 199.03 \\
& Strongly agree & 277 & \\
\hline
\end{tabular}




\begin{tabular}{|c|c|c|c|}
\hline \multirow{6}{*}{$\begin{array}{l}\text { C. Resource support at the } \\
\text { school (technological, print } \\
\text { or otherwise) was } \\
\text { influential in my decision to } \\
\text { leave the school. }\end{array}$} & Strongly disagree & 77 & 75.14 \\
\hline & Disagree & 101 & 142.00 \\
\hline & Undecided & 20 & 184.35 \\
\hline & Agree & 50 & 171.23 \\
\hline & Strongly agree & 29 & 211.26 \\
\hline & Total & 277 & \\
\hline \multirow{6}{*}{$\begin{array}{l}\text { D. Student behavior at the } \\
\text { school was influential in my } \\
\text { decision to leave the } \\
\text { school. }\end{array}$} & Strongly disagree & 77 & 86.82 \\
\hline & Disagree & 101 & 143.60 \\
\hline & Undecided & 20 & 137.60 \\
\hline & Agree & 49 & 172.02 \\
\hline & Strongly agree & 29 & 201.95 \\
\hline & Total & 276 & \\
\hline \multirow{6}{*}{$\begin{array}{l}\text { E. Parental support of } \\
\text { teachers was influential in } \\
\text { my decision to leave the } \\
\text { school. }\end{array}$} & Strongly disagree & 77 & 97.08 \\
\hline & Disagree & 101 & 141.49 \\
\hline & Undecided & 20 & 159.53 \\
\hline & Agree & 48 & 157.67 \\
\hline & Strongly agree & 29 & 187.09 \\
\hline & Total & 275 & \\
\hline \multirow{7}{*}{$\begin{array}{l}\text { F. The quality of the school } \\
\text { facility was influential in my } \\
\text { decision to leave the } \\
\text { school. }\end{array}$} & Strongly disagree & 77 & 71.26 \\
\hline & Disagree & 101 & 142.81 \\
\hline & Undecided & 20 & 171.60 \\
\hline & Agree & 49 & 175.08 \\
\hline & Strongly agree & 29 & 217.38 \\
\hline & Total & & \\
\hline & & 276 & \\
\hline \multirow{6}{*}{$\begin{array}{l}\text { H. The stability of my } \\
\text { teaching assignment at the } \\
\text { school was influential in my } \\
\text { decision to leave the } \\
\text { school. }\end{array}$} & Strongly disagree & 77 & 80.74 \\
\hline & Disagree & 101 & 156.29 \\
\hline & Undecided & 20 & 125.50 \\
\hline & Agree & 50 & 181.89 \\
\hline & Strongly agree & 28 & 164.98 \\
\hline & Total & 276 & \\
\hline \multirow{6}{*}{$\begin{array}{l}\text { I. Expectations regarding } \\
\text { teacher workload were } \\
\text { influential in my decision to } \\
\text { leave the school. }\end{array}$} & Strongly disagree & 77 & 103.64 \\
\hline & Disagree & 101 & 141.96 \\
\hline & Undecided & 20 & 135.28 \\
\hline & Agree & 50 & 171.21 \\
\hline & Strongly agree & 29 & 169.62 \\
\hline & Total & 277 & \\
\hline \multirow{6}{*}{$\begin{array}{l}\text { J. Communication between } \\
\text { senior management and } \\
\text { faculty at the school was } \\
\text { influential in my decision to } \\
\text { leave the school. }\end{array}$} & Strongly disagree & 77 & 100.42 \\
\hline & Disagree & 101 & 136.58 \\
\hline & Undecided & 20 & 144.98 \\
\hline & Agree & 49 & 171.20 \\
\hline & Strongly agree & 29 & 186.55 \\
\hline & Total & 276 & \\
\hline
\end{tabular}




\begin{tabular}{|c|c|c|c|}
\hline & Strongly disagree & 77 & 115.95 \\
\hline $\begin{array}{l}\text { compensation package } \\
\text { offered to me was }\end{array}$ & Disagree & 100 & 143.94 \\
\hline influential in my decision to & Undecided & 20 & 133.90 \\
\hline leave the school. & Agree & 50 & 156.04 \\
\hline & Strongly agree & 28 & 148.14 \\
\hline & Total & 275 & \\
\hline L. Opportunities for & Strongly disagree & 76 & 108.88 \\
\hline leadership at the school & Disagree & 101 & 141.15 \\
\hline decision to leave the & Undecided & 20 & 130.85 \\
\hline school. & Agree & 50 & 164.92 \\
\hline & Strongly agree & 29 & 166.60 \\
\hline & Total & 276 & \\
\hline M. Teacher involvement in & Strongly disagree & 76 & 103.71 \\
\hline decision making at the & Disagree & 101 & 145.65 \\
\hline $\begin{array}{l}\text { decision to leave the } \\
\text { dent }\end{array}$ & Undecided & 20 & 140.58 \\
\hline school. & Agree & 50 & 153.78 \\
\hline & Strongly agree & 29 & 177.00 \\
\hline & Total & 276 & \\
\hline N. A mismatch between my & Strongly disagree & 76 & 94.96 \\
\hline expectations regarding the & Disagree & 101 & 136.79 \\
\hline the reality when I arrived & Undecided & 20 & 136.35 \\
\hline was influential in my & Agree & 50 & 169.25 \\
\hline decision to leave the & Strongly agree & 28 & 204.55 \\
\hline & Total & 275 & \\
\hline O. Opportunities for & Strongly disagree & 77 & 98.17 \\
\hline $\begin{array}{l}\text { professional advancement } \\
\text { elsewhere were influential }\end{array}$ & Disagree & 101 & 137.18 \\
\hline in my decision to leave the & Undecided & 20 & 152.10 \\
\hline school. & Agree & 50 & 174.04 \\
\hline & Strongly agree & 29 & 184.31 \\
\hline & Total & 277 & \\
\hline P. Personal circumstances & Strongly disagree & 76 & 154.43 \\
\hline $\begin{array}{l}\text { were influentlal in my } \\
\text { decision to leave the }\end{array}$ & Disagree & 101 & 138.02 \\
\hline school. & Undecided & 20 & 147.80 \\
\hline & Agree & 50 & 129.49 \\
\hline & Strongly agree & 29 & 107.53 \\
\hline & Tota! & 276 & \\
\hline Q. Living conditions in the & Strongly disagree & 77 & 111.48 \\
\hline $\begin{array}{l}\text { host country were } \\
\text { influential in my decision to }\end{array}$ & Disagree & 101 & 150.75 \\
\hline $\begin{array}{l}\text { leave the school. } \\
\text { lasto }\end{array}$ & Undecided & 20 & 161.10 \\
\hline & Agree & 50 & 150.23 \\
\hline & Strongly agree & 29 & 136.53 \\
\hline & Total & 277 & \\
\hline$R$. The quality of my & Strongly disagree & 77 & 129.36 \\
\hline $\begin{array}{l}\text { personal life whlle at the } \\
\text { school was influential in my }\end{array}$ & Disagree & 101 & 144.37 \\
\hline decision to leave the & Undecided & 20 & 152.15 \\
\hline school. & Agree & 50 & 145.92 \\
\hline & Strongly agree & 28 & 119.46 \\
\hline
\end{tabular}




Total 276

Test Statistics by Perceived academic strength $(a, b)$

A. The level of support from the principal and senior management at the school was influential in my decision to leave the school.

$B$. The quality of the induction program was influential in my decision to leave the school.

C. Resource support at the school (technological, print or otherwise) was influential in my decision to leave the school.

D. Student behavior at the school was influential in my decision to leave the school.

E. Parental support of teachers was influential in my decision to leave the school

$F$. The quality of the school facility was influential in my decision to leave the school.

$H$. The stability of my teaching assignment at the school was influential in my decision to leave the school.

I. Expectations regarding teacher workload were influential in my decision to leave the school.

$\mathrm{J}$. Communication between senior management and faculty at the school was influential in my decision to leave the school.

$K$. The overall compensation package offered to me was influential in my decision to leave the school.

L. Opportunities for leadership at the school were influential in my decision to leave the school.

$M$. Teacher involvement in decision making at the school was influential in my decision to leave the school.

N. A mismatch belween my expectations regarding the school and/or my role and the reality when I arrived was influential in my decision to leave the school.

O. Opportunities for professional advancement elsewhere were influential in my decision to leave the school.

$P$. Personal circumstances were influential in my decision to leave the school.

Q. Living conditions in the host country were influential in my decision to leave the school.

$R$. The quality of my personal life while at the school was influential in my decision to leave the school.

a Kruskal Wallis Test

b Grouping Variable: $\mathrm{G}$. The academic standards of the school were influential in my decision to leave the school.

\section{Chi-Square}

df

Asymp. Sig.

28.881

62.251

93.092

69.603

39.777

103.538

70.207

4

.000

29.503

4

.000

39.711

4

10.045

4

.040

21.167

4

.000

25.167

4

.000

52.467

4

.000

41.579

4

.000

8.730

4

.068

14.686

4

.005

4.380

4 
Mean Ranks by Ownership structure

\begin{tabular}{|c|c|c|c|}
\hline \multirow{5}{*}{$\begin{array}{l}\text { A. The level of support from } \\
\text { the principal and senior } \\
\text { management at the school } \\
\text { was influential in my } \\
\text { decision to leave the } \\
\text { school. }\end{array}$} & $\begin{array}{l}\text { In which category } \\
\text { did your school fit? }\end{array}$ & $N$ & Mean Rank \\
\hline & Not for profit/trust & 134 & 128.29 \\
\hline & Privately owned & 124 & 145.71 \\
\hline & $\begin{array}{l}\text { Multinational } \\
\text { corporation owned }\end{array}$ & 16 & 150.97 \\
\hline & Total & 274 & \\
\hline \multirow{4}{*}{$\begin{array}{l}\text { B. The quality of the } \\
\text { induction program was } \\
\text { influential in my decision to } \\
\text { leave the school. }\end{array}$} & Not for profit/trust & 136 & 121.77 \\
\hline & Privately owned & 124 & 154.57 \\
\hline & $\begin{array}{l}\text { Multinational } \\
\text { corporation owned }\end{array}$ & 15 & 148.13 \\
\hline & Total & 275 & \\
\hline \multirow{4}{*}{$\begin{array}{l}\text { C. Resource support at the } \\
\text { school (technological, print } \\
\text { or otherwise) was } \\
\text { influential in my decision to } \\
\text { leave the school. }\end{array}$} & Not for profit/trust & 136 & 117.48 \\
\hline & Privately owned & 124 & 156.70 \\
\hline & $\begin{array}{l}\text { Multinational } \\
\text { corporation owned }\end{array}$ & 15 & 169.47 \\
\hline & Total & 275 & \\
\hline \multirow{5}{*}{$\begin{array}{l}\text { D. Student behavior at the } \\
\text { school was influential in my } \\
\text { decision to leave the } \\
\text { school. }\end{array}$} & Not for profit/trust & 135 & 128.96 \\
\hline & Privately owned & 124 & 148.23 \\
\hline & $\begin{array}{l}\text { Multinational } \\
\text { corporation owned }\end{array}$ & 15 & 125.67 \\
\hline & Total & & \\
\hline & & 274 & \\
\hline \multirow{4}{*}{$\begin{array}{l}\text { E. Parental support of } \\
\text { teachers was influential in } \\
\text { my decision to leave the } \\
\text { school. }\end{array}$} & Not for profittrust & 136 & 134.79 \\
\hline & Privately owned & 122 & 141.01 \\
\hline & $\begin{array}{l}\text { Multinational } \\
\text { corporation owned }\end{array}$ & 16 & 133.75 \\
\hline & Total & 274 & \\
\hline \multirow{4}{*}{$\begin{array}{l}\text { F. The quality of the school } \\
\text { facility was influential in my } \\
\text { decision to leave the } \\
\text { school. }\end{array}$} & Not for profit/trust & 135 & 117.22 \\
\hline & Privately owned & 124 & 156.23 \\
\hline & $\begin{array}{l}\text { Multinational } \\
\text { corporation owned }\end{array}$ & 16 & 172.06 \\
\hline & Total & 275 & \\
\hline \multirow{4}{*}{$\begin{array}{l}\text { G. The academic standards } \\
\text { of the school were } \\
\text { influential in my decision to } \\
\text { leave the school. }\end{array}$} & Not for profit/trust & 135 & 115.63 \\
\hline & Privately owned & 124 & 160.55 \\
\hline & $\begin{array}{l}\text { Multinational } \\
\text { corporation owned }\end{array}$ & 15 & 143.80 \\
\hline & Total & 274 & \\
\hline \multirow{2}{*}{$\begin{array}{l}H . \text { The stability of my } \\
\text { teaching assignment at the }\end{array}$} & Not for profit/trust & 137 & 132.40 \\
\hline & Privately owned & 123 & 142.64 \\
\hline
\end{tabular}




\begin{tabular}{|c|c|c|c|}
\hline \multirow{2}{*}{$\begin{array}{l}\text { school was influential in my } \\
\text { decision to leave the } \\
\text { school. }\end{array}$} & $\begin{array}{l}\text { Multinational } \\
\text { corporation owned }\end{array}$ & 16 & \multirow[t]{2}{*}{158.88} \\
\hline & Total & 276 & \\
\hline \multirow{4}{*}{$\begin{array}{l}\text { I. Expectations regarding } \\
\text { teacher workload were } \\
\text { influential in my decision to } \\
\text { leave the school. }\end{array}$} & Not for profit/trust & 137 & 136.90 \\
\hline & Privately owned & 124 & 140.42 \\
\hline & $\begin{array}{l}\text { Multinational } \\
\text { corporation owned }\end{array}$ & 15 & 137.27 \\
\hline & Total & 276 & \\
\hline \multirow{4}{*}{$\begin{array}{l}\text { J. Communication between } \\
\text { senior management and } \\
\text { faculty at the school was } \\
\text { influential in my decision to } \\
\text { leave the school. }\end{array}$} & Not for profit/trust & 136 & 126.18 \\
\hline & Privately owned & 123 & 149.18 \\
\hline & $\begin{array}{l}\text { Multinational } \\
\text { corporation owned }\end{array}$ & 16 & 152.53 \\
\hline & Total & 275 & \\
\hline \multirow{4}{*}{$\begin{array}{l}\text { K. The overall } \\
\text { compensation package } \\
\text { offered to me was } \\
\text { influential in my decision to } \\
\text { leave the school. }\end{array}$} & Not for profittrust & 136 & 137.00 \\
\hline & Privately owned & 123 & 141.22 \\
\hline & $\begin{array}{l}\text { Multinational } \\
\text { corporation owned }\end{array}$ & 15 & 111.53 \\
\hline & Total & 274 & \\
\hline \multirow{4}{*}{$\begin{array}{l}\text { L. Opportunities for } \\
\text { leadership at the school } \\
\text { were influential in my } \\
\text { decision to leave the } \\
\text { school. }\end{array}$} & Not for profit/trust & 135 & 134.63 \\
\hline & Privately owned & 124 & 144.17 \\
\hline & $\begin{array}{l}\text { Multinational } \\
\text { corporation owned }\end{array}$ & 15 & 108.20 \\
\hline & Total & 274 & \\
\hline \multirow{4}{*}{$\begin{array}{l}\text { M. Teacher involvement in } \\
\text { decision making at the } \\
\text { school was influential in my } \\
\text { decision to leave the } \\
\text { school. }\end{array}$} & Not for profit/trust & 135 & 125.80 \\
\hline & Privately owned & 124 & 150.11 \\
\hline & $\begin{array}{l}\text { Multinational } \\
\text { corporation owned }\end{array}$ & 16 & 147.13 \\
\hline & Total & 275 & \\
\hline \multirow{8}{*}{$\begin{array}{l}\text { N. A mismatch between my } \\
\text { expectations regarding the } \\
\text { school and/or my role and } \\
\text { the reality when I arrived } \\
\text { was influential in my } \\
\text { decision to leave the } \\
\text { school. } \\
\text { O. Opportunities for } \\
\text { professional advancement } \\
\text { elsewhere were influential } \\
\text { in my decision to leave the } \\
\text { school. }\end{array}$} & Not for profit/trust & 135 & 126.24 \\
\hline & Privately owned & 123 & 148.58 \\
\hline & $\begin{array}{l}\text { Multinational } \\
\text { corporation owned }\end{array}$ & 15 & 138.87 \\
\hline & Total & 273 & \\
\hline & Not for profit/trust & 136 & 122.63 \\
\hline & Privately owned & 124 & 156.23 \\
\hline & $\begin{array}{l}\text { Multinational } \\
\text { corporation owned }\end{array}$ & 15 & 126.67 \\
\hline & Total & 275 & \\
\hline \multirow{4}{*}{$\begin{array}{l}\text { P. Personal circumstances } \\
\text { were influential in my } \\
\text { decision to leave the } \\
\text { school. }\end{array}$} & Not for profit/trust & 136 & 133.06 \\
\hline & Privately owned & 124 & 142.08 \\
\hline & $\begin{array}{l}\text { Multinational } \\
\text { corporation owned }\end{array}$ & 15 & 149.07 \\
\hline & Total & 275 & \\
\hline \multirow{4}{*}{$\begin{array}{l}\text { Q. Living conditions in the } \\
\text { host country were } \\
\text { influential in my decision to } \\
\text { leave the school. }\end{array}$} & Not for profit/trust & 137 & 129.36 \\
\hline & Privately owned & 124 & 147.82 \\
\hline & $\begin{array}{l}\text { Multinational } \\
\text { corporation owned }\end{array}$ & 15 & 144.93 \\
\hline & Total & 276 & \\
\hline
\end{tabular}




\begin{tabular}{llcc}
\hline R. The quality of my & Not for profit/trust & 137 & 125.58 \\
personal life while at the & Privately owned & 123 & 150.43 \\
$\begin{array}{l}\text { school was influential in my } \\
\text { decision to leave the }\end{array}$ & $\begin{array}{l}\text { Multinational } \\
\text { school. }\end{array}$ & 16 & 157.44 \\
& $\begin{array}{l}\text { Corporation owned } \\
\text { Total }\end{array}$ & 276 & \\
\hline
\end{tabular}

Test Statistics by Ownership structure(a,b)

A. The level of support from the principal and senior management at the school was influential in my decision to leave the school.

B. The quality of the induction program was influential in my decision to leave the school.

C. Resource support at the school (technological, print or otherwise) was influential in my decision to leave the school.

D. Student behavior at the school was influential in my decision to leave the school.

E. Parental support of teachers was influential in my decision to leave the school.

F. The quality of the school facility was influential in my decision to leave the school.

$G$. The academic standards of the school were influential in my decision to leave the school.

$H$. The stability of my teaching assignment at the school was influential in my decision to leave the school.

I. Expectations regarding teacher workload were influential in my decision to leave the school.

J. Communication between senior management and faculty at the school was influential in my decision to leave the school.

$\mathrm{K}$. The overall compensation package offered to me was influential in my decision to leave the school.

L. Opportunities for leadership at the school were influential in my decision to leave the school.

$M$. Teacher involvement in decision making at the school was influential in my decision to leave the school.

N. A mismatch between my expectations regarding the school and/or my role and the reality when I arrived was influential in my decision to leave the school.

O. Opportunities for professional advancement elsewhere were influential in my decision to leave the school.

1.201

3.818

7.616

df

Asymp. Sig.

3.915

2

.141

12.271

2

.002

19.492

2

.000

4.886

2

2

19.917

2

22.623

2

.000

2.395

2

.302

2

6.493

2

.039

1.985

2

.371

3.312

2

6.611

2

.037

5.456

2

.065

$P$. Personal circumstances were influential in my decision to leave the school.

Q. Living conditions in the host country were influential in my decision to leave the school.

R. The quality of my personal life while at the school was influential in my decision to leave the school.

a Kruskal Wallis Test

b Grouping Variable: In which category did your school fit? 


\begin{tabular}{|c|c|c|c|}
\hline & Gender & $N$ & $\begin{array}{l}\text { Mean } \\
\text { Rank }\end{array}$ \\
\hline \multirow{3}{*}{$\begin{array}{l}\text { A. The level of support from the principal and senior } \\
\text { management at the school was influential in my decision to } \\
\text { leave the school. }\end{array}$} & Female & 168 & 139.85 \\
\hline & Male & 109 & 137.68 \\
\hline & Total & 277 & \\
\hline \multirow{4}{*}{$\begin{array}{l}\text { B. The quality of the induction program was influential in my } \\
\text { decision to leave the school. }\end{array}$} & Female & 168 & 146.68 \\
\hline & Male & 110 & 128.53 \\
\hline & Total & 278 & \\
\hline & Female & 168 & 138.95 \\
\hline \multirow{2}{*}{$\begin{array}{l}\text { C. Resource support at the school (technological, print or } \\
\text { otherwise) was influential in my decision to leave the school. }\end{array}$} & Male & 110 & 140.34 \\
\hline & Total & 278 & \\
\hline \multirow{3}{*}{$\begin{array}{l}\text { D. Student behavior at the school was influential in my decision } \\
\text { to leave the school. }\end{array}$} & Female & 167 & 135.13 \\
\hline & Male & 110 & 144.88 \\
\hline & Total & 277 & \\
\hline \multirow{3}{*}{$\begin{array}{l}\text { E. Parental support of teachers was influential in my decision to } \\
\text { leave the school. }\end{array}$} & Female & 167 & 143.25 \\
\hline & Male & 110 & 132.54 \\
\hline & Total & 277 & \\
\hline \multirow{3}{*}{$\begin{array}{l}\text { F. The quality of the school facility was influential in my decision } \\
\text { to leave the school. }\end{array}$} & Female & 168 & 139.76 \\
\hline & Male & 110 & 139.10 \\
\hline & Total & 278 & \\
\hline \multirow{3}{*}{$\begin{array}{l}\text { G. The academic standards of the school were influential in my } \\
\text { decision to leave the school. }\end{array}$} & Female & 168 & 134.29 \\
\hline & Male & 109 & 146.26 \\
\hline & Total & 277 & \\
\hline \multirow{3}{*}{$\begin{array}{l}\text { H. The stability of my teaching assignment at the school was } \\
\text { influential in my decision to leave the school. }\end{array}$} & Female & 169 & 140.37 \\
\hline & Male & 110 & 139.44 \\
\hline & Total & 279 & \\
\hline \multirow{3}{*}{$\begin{array}{l}\text { 1. Expectations regarding teacher workload were influential in my } \\
\text { decision to leave the school. }\end{array}$} & Female & 169 & 143.06 \\
\hline & Male & 110 & 135.30 \\
\hline & Total & 279 & \\
\hline \multirow{3}{*}{$\begin{array}{l}\text { J. Communication between senior management and faculty at } \\
\text { the school was influential in my decision to leave the school. }\end{array}$} & Female & 167 & 140.60 \\
\hline & Male & 111 & 137.85 \\
\hline & Total & 278 & \\
\hline \multirow{3}{*}{$\begin{array}{l}\text { K. The overall compensation package offered to me was } \\
\text { influential in my decision to leave the school. }\end{array}$} & Female & 168 & 135.58 \\
\hline & Male & 109 & 144.27 \\
\hline & Total & 277 & \\
\hline \multirow{3}{*}{$\begin{array}{l}\text { L. Opportunities for leadership at the school were influential in } \\
\text { my decision to leave the school. }\end{array}$} & Female & 168 & 132.67 \\
\hline & Male & 109 & 148.76 \\
\hline & Total & 277 & \\
\hline \multirow{2}{*}{$\begin{array}{l}\text { M. Teacher involvement in decision making at the school was } \\
\text { influential in my decision to leave the schoo!. }\end{array}$} & Female & 168 & 136.35 \\
\hline & Male & 110 & 144.30 \\
\hline
\end{tabular}




\begin{tabular}{|c|c|c|c|}
\hline & Total & 278 & \\
\hline \multirow{3}{*}{$\begin{array}{l}\text { N. A mismatch between my expectations regarding the school } \\
\text { and/or my role and the reality when I arrived was influential in } \\
\text { my decision to leave the school. }\end{array}$} & Female & 168 & 140.23 \\
\hline & Male & 108 & 135.81 \\
\hline & Total & 276 & \\
\hline \multirow{3}{*}{$\begin{array}{l}\text { O. Opportunities for professional advancement elsewhere were } \\
\text { influential in my decision to leave the school. }\end{array}$} & Female & 168 & 134.36 \\
\hline & Male & 110 & 147.35 \\
\hline & Total & 278 & \\
\hline \multirow{3}{*}{$\begin{array}{l}\text { P. Personal circumstances were influential in my decision to } \\
\text { leave the school. }\end{array}$} & Female & 168 & 141.17 \\
\hline & Male & 110 & 136.95 \\
\hline & Total & 278 & \\
\hline \multirow{3}{*}{$\begin{array}{l}\text { Q. Living conditions in the host country were influential in my } \\
\text { decision to leave the school. }\end{array}$} & Female & 169 & 144.92 \\
\hline & Male & 110 & 132.44 \\
\hline & Total & 279 & \\
\hline \multirow{3}{*}{$\begin{array}{l}\text { R. The quality of my personal life while at the school was } \\
\text { influential in my decision to leave the school. }\end{array}$} & Female & 168 & 144.66 \\
\hline & Male & 111 & 132.95 \\
\hline & Total & 279 & \\
\hline
\end{tabular}

Test Statistics by gender $(a, b)$

A. The level of support from the principal and senior management at the school was influential in my decision to leave the school.

$B$. The quality of the induction program was influential in my decision to leave the school.

C. Resource support at the school (technological, print or otherwise) was influential in my decision to leave the school.

D. Student behavior at the school was influential in my decision to leave the school.

E. Parental support of teachers was influential in my decision to leave the school.

$F$. The quality of the school facility was influential in my decision to leave the school.

G. The academic standards of the school were influential in my decision to leave the school.

$H$. The stability of my teaching assignment at the school was influential in my decision to leave the school.

I. Expectations regarding teacher worklozd were influential in my decision to leave the school.

J. Communication between senior management and faculty at the school was influential in my decision to leave the school.

$K$. The overall compensation package offered to me was influential in my decision to leave the school.

L. Opportunities for leadership at the school were influential in my decision to leave the school.
Chi-Square

df

Asymp. Sig.

.053
3.682
.021

.818

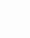

.055

1.149

1.309

1

1

1.601

1

.206

.010

1

.660

1

.417

.085

1

.771

.818

1

.366

2.847

1 
$M$. Teacher involvement in decision making at the school was influential in my decision to leave the school.

N. A mismatch between my expectations regarding the school and/or my role and the reality when I arrived was influential in my decision to leave the school.

O. Opportunities for professional advancement elsewhere were influential in my decision to leave the school.

$P$. Personal circumstances were influential in my decision to leave the school.

Q. Living conditions in the host country were influential in my decision to leave the school.

R. The quality of my personal life while at the school was influential in my decision to leave the school.

a Kruskal Wallis Test

b Grouping Variable: Gender

\section{Mean Ranks by Age}

\begin{tabular}{|c|c|c|c|}
\hline \multirow{6}{*}{$\begin{array}{l}\text { A. The level of support from } \\
\text { the principal and senior } \\
\text { management at the school } \\
\text { was influential in my } \\
\text { decision to leave the } \\
\text { school. }\end{array}$} & $\begin{array}{l}\text { Age in the year in } \\
\text { which you left: }\end{array}$ & $N$ & Mean Rank \\
\hline & 29 or lower & 57 & 149.20 \\
\hline & $30-39$ & 105 & 136.06 \\
\hline & $40-49$ & 65 & 141.85 \\
\hline & $50-59$ & 46 & 125.28 \\
\hline & 60 or higher & 4 & 182.25 \\
\hline \multirow{7}{*}{$\begin{array}{l}\text { B. The quality of the } \\
\text { induction program was } \\
\text { influential in my decision to } \\
\text { leave the school. }\end{array}$} & Total & 277 & \\
\hline & 29 or lower & 57 & 156.88 \\
\hline & $30-39$ & 105 & 136.78 \\
\hline & $40-49$ & 65 & 133.27 \\
\hline & $50-59$ & 47 & 132.66 \\
\hline & 60 or higher & 4 & 145.00 \\
\hline & Total & 278 & \\
\hline \multirow{6}{*}{$\begin{array}{l}\text { C. Resource support at the } \\
\text { school (technological, print } \\
\text { or otherwise) was } \\
\text { influential in my decision to } \\
\text { leave the school. }\end{array}$} & 29 or lower & 57 & 155.29 \\
\hline & $30-39$ & 105 & 135.62 \\
\hline & $40-49$ & 65 & 139.92 \\
\hline & $50-59$ & 47 & 131.41 \\
\hline & 60 or higher & 4 & 104.50 \\
\hline & Total & 278 & \\
\hline \multirow{6}{*}{$\begin{array}{l}\text { D. Student behavior at the } \\
\text { school was influential in my } \\
\text { decision to leave the } \\
\text { school. }\end{array}$} & 29 or lower & 57 & 137.16 \\
\hline & $30-39$ & 105 & 139.83 \\
\hline & $40-49$ & 65 & 133.65 \\
\hline & $50-59$ & 46 & 143.68 \\
\hline & 60 or higher & 4 & 176.50 \\
\hline & Total & 277 & \\
\hline E. Parental support of & 29 or lower & 55 & 142.20 \\
\hline
\end{tabular}




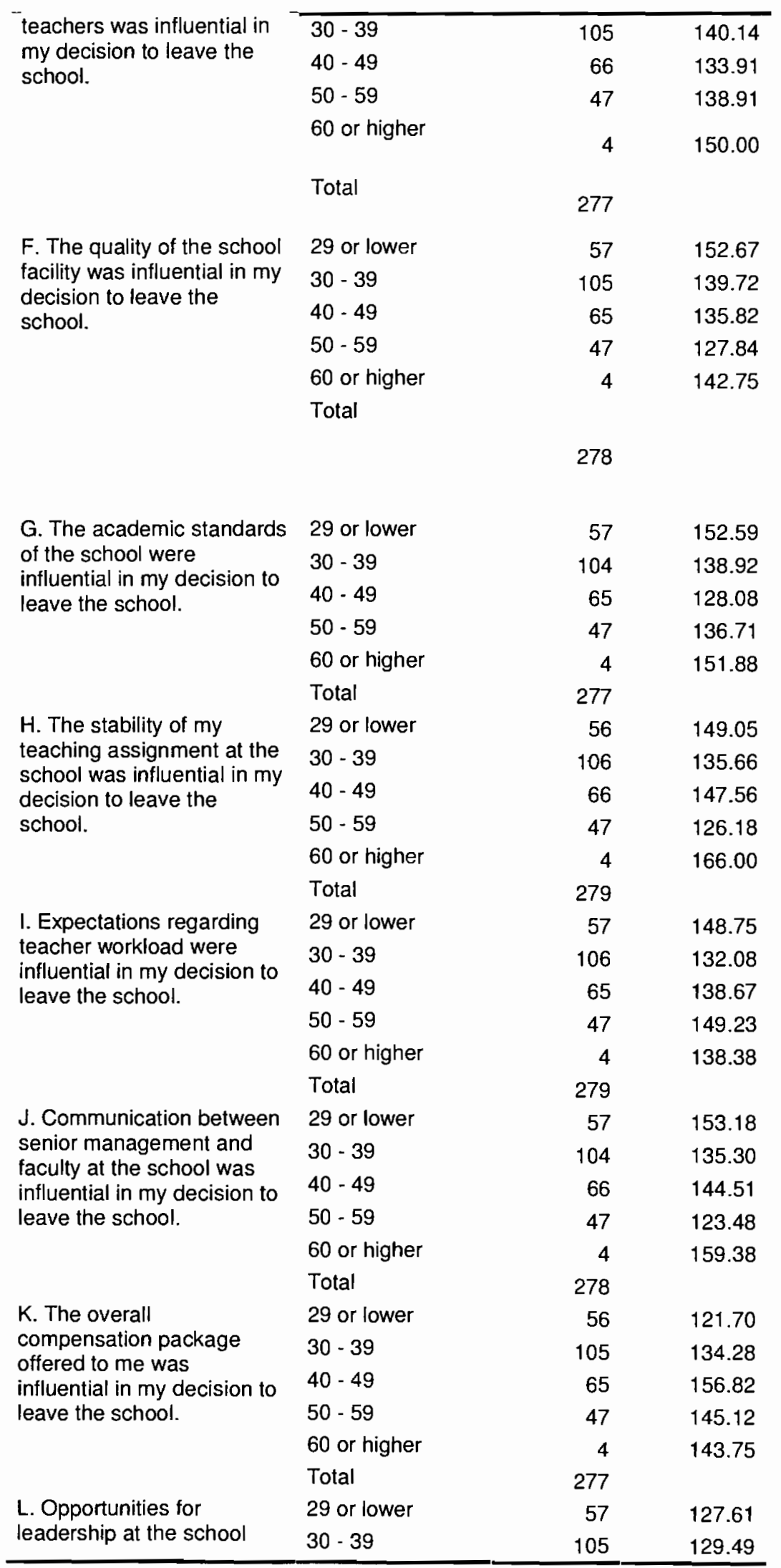


were influential in my decision to leave the school.

$M$. Teacher involvement in decision making at the school was influential in my decision to leave the school.

N. A mismatch between my expectations regarding the school and/or my role and the reality when I arrived was influential in my decision to leave the school.

O. Opportunities for professional advancement elsewhere were influential in my decision to leave the school.

P. Personal circumstances were influential in my decision to leave the school.

\begin{tabular}{|c|c|c|c|}
\hline \multirow{4}{*}{$\begin{array}{l}\text { were influential in my } \\
\text { decision to leave the } \\
\text { school. }\end{array}$} & $40-49$ & 64 & 160.59 \\
\hline & $50-59$ & 47 & 143.77 \\
\hline & 60 or higher & 4 & 149.63 \\
\hline & Total & 277 & \\
\hline \multirow{6}{*}{$\begin{array}{l}\text { M. Teacher involverment in } \\
\text { decision making at the } \\
\text { school was influential in my } \\
\text { decision to leave the } \\
\text { school. }\end{array}$} & 29 or lower & 57 & 139.96 \\
\hline & $30-39$ & 105 & 131.30 \\
\hline & $40-49$ & 65 & 144.93 \\
\hline & $50-59$ & 47 & 147.56 \\
\hline & 60 or higher & 4 & 165.25 \\
\hline & Total & 278 & \\
\hline \multirow{6}{*}{$\begin{array}{l}\text { N. A mismatch between my } \\
\text { expectations regarding the } \\
\text { school and/or my role and } \\
\text { the reality when I arrived } \\
\text { was influential in my } \\
\text { decision to leave the } \\
\text { school. }\end{array}$} & 29 or lower & 57 & 137.37 \\
\hline & $30-39$ & 105 & 141.95 \\
\hline & $40-49$ & 65 & 132.31 \\
\hline & $50-59$ & 45 & 140.51 \\
\hline & 60 or higher & 4 & 142.00 \\
\hline & Total & 276 & \\
\hline \multirow{6}{*}{$\begin{array}{l}\text { O. Opportunities for } \\
\text { professional advancement } \\
\text { elsewhere were influential } \\
\text { in my decision to leave the } \\
\text { school. }\end{array}$} & 29 or lower & 57 & 148.24 \\
\hline & $30-39$ & 105 & 145.18 \\
\hline & $40-49$ & 65 & 139.48 \\
\hline & $50-59$ & 47 & 120.38 \\
\hline & 60 or higher & 4 & 91.00 \\
\hline & Total & 278 & \\
\hline \multirow{6}{*}{$\begin{array}{l}\text { P. Personal circumstances } \\
\text { were influential in my } \\
\text { decision to leave the } \\
\text { school. }\end{array}$} & 29 or lower & 57 & 140.90 \\
\hline & $30-39$ & 106 & 136.46 \\
\hline & $40-49$ & 65 & 131.56 \\
\hline & $50-59$ & 46 & 153.43 \\
\hline & 60 or higher & 4 & 168.75 \\
\hline & Total & 278 & \\
\hline \multirow{6}{*}{$\begin{array}{l}\text { Q. Living conditions in the } \\
\text { host country were } \\
\text { influential in my decision to } \\
\text { leave the school. }\end{array}$} & 29 or lower & 57 & 152.41 \\
\hline & $30-39$ & 106 & 143.28 \\
\hline & $40-49$ & 65 & 126.47 \\
\hline & $50-59$ & 47 & 139.26 \\
\hline & 60 or higher & 4 & 104.88 \\
\hline & Total & 279 & \\
\hline \multirow{6}{*}{$\begin{array}{l}\text { R. The quality of my } \\
\text { personal life while at the } \\
\text { school was influential in my } \\
\text { decision to leave the } \\
\text { school. }\end{array}$} & 29 or lower & 56 & 143.75 \\
\hline & $30-39$ & 106 & 139.77 \\
\hline & $40-49$ & 66 & 132.82 \\
\hline & $50-59$ & 47 & 150.78 \\
\hline & 60 or higher & 4 & 85.38 \\
\hline & Total & 279 & \\
\hline
\end{tabular}

Q. Living conditions in the host country were influential in my decision to leave the school.

R. The quality of my
personal life while at the
school was influential in my
decision to leave the
school.




\section{Test Statistics by Age $(a, b)$}

A. The level of support from the principal and senior management at the school was influential in my decision to leave the school.

$B$. The quality of the induction program was influential in my decision to leave the school.

C. Resource support at the school (technological, print or otherwise) was influential in my decision to leave the school.

D. Student behavior at the school was influential in my decision to leave the school.

E. Parental support of teachers was influential in my decision to leave the school.

F. The quality of the school facility was influential in my decision to leave the school.

G. The academic standards of the school were influential in my decision to leave the school.

$\mathrm{H}$. The stability of my teaching assignment at the school was influential in my decision to leave the school.

I. Expectations regarding teacher workload were influential in my decision to leave the school.

J. Communication between senior management and faculty at the school was influential in my decision to leave the school.

$K$. The overall compensation package offered to me was influential in my decision to leave the school.

L. Opportunities for leadership at the school were influential in my decision to leave the school.

$M$. Teacher involvement in decision making at the school was influential in my decision to leave the school.

N. A mismatch between my expectations regarding the school and/or my role and the reality when I arrived was influential in my decision to leave the school.

O. Opportunities for professional advancement elsewhere were influential in my decision to leave the school.

$P$. Personal circumstances were influential in my decision to leave the school.

Q. Living conditions in the host country were influential in my decision to leave the school.

$R$. The quality of my personal life while at the school was influential in my decision to leave the school.
Chi-Square

df

Asymp. Sig.

3.985

4

.408

3.837

4

3.925

4

1.595

4

.810

.498

4

.974

2.840

4

3.241

4

.518

3.725

4

.444

2.499

4

.645

4.688

4

6.815

4

8.023

4

.091

2.402

4

.662

.672

4

5.597

4

4

4.378

4

3.486

a Kruskal Wallis Test

b Grouping Variable: Age in the year in which you left: 
Mean Ranks by Marital Status

\begin{tabular}{|c|c|c|c|}
\hline & $\begin{array}{l}\text { Marital Status in the } \\
\text { year in which you left: }\end{array}$ & $N$ & Mean Rank \\
\hline \multirow{3}{*}{$\begin{array}{l}\text { A. The level of support from the principal and } \\
\text { senior management at the school was } \\
\text { influential in my decision to leave the school. }\end{array}$} & Single & 171 & 143.04 \\
\hline & Married & 106 & 132.49 \\
\hline & Total & 277 & \\
\hline \multirow{3}{*}{$\begin{array}{l}\text { B. The quality of the induction program was } \\
\text { influential in my decision to leave the school. }\end{array}$} & Single & 169 & 149.38 \\
\hline & Married & 109 & 124.18 \\
\hline & Total & 278 & \\
\hline \multirow{4}{*}{$\begin{array}{l}\text { C. Resource support at the school } \\
\text { (technological, print or otherwise) was } \\
\text { influential in my decision to leave the school. }\end{array}$} & Single & 169 & 148.70 \\
\hline & Married & 109 & 125.24 \\
\hline & Total & & \\
\hline & & 278 & \\
\hline \multirow{3}{*}{$\begin{array}{l}\text { D. Student behavior at the school was } \\
\text { influential in my decision to leave the school. }\end{array}$} & Single & 168 & 138.65 \\
\hline & Married & 109 & 139.55 \\
\hline & Total & 277 & \\
\hline \multirow{3}{*}{$\begin{array}{l}\text { E. Parental support of teachers was influential } \\
\text { in my decision to leave the school. }\end{array}$} & Single & 168 & 141.81 \\
\hline & Married & 109 & 134.67 \\
\hline & Total & 277 & \\
\hline \multirow{3}{*}{$\begin{array}{l}\text { F. The quality of the school facility was } \\
\text { influential in my decision to leave the school. }\end{array}$} & Single & 170 & 148.14 \\
\hline & Married & 108 & 125.91 \\
\hline & Total & 278 & \\
\hline \multirow{3}{*}{$\begin{array}{l}\text { G. The academic standards of the school were } \\
\text { influential in my decision to leave the school. }\end{array}$} & Single & 169 & 141.46 \\
\hline & Married & 108 & 135.14 \\
\hline & Total & 277 & \\
\hline \multirow{3}{*}{$\begin{array}{l}\mathrm{H} \text {. The stability of my teaching assignment at } \\
\text { the school was influential in my decision to } \\
\text { leave the school. }\end{array}$} & Single & 170 & 150.09 \\
\hline & Married & 109 & 124.27 \\
\hline & Total & 279 & \\
\hline \multirow{3}{*}{$\begin{array}{l}\text { I. Expectations regarding teacher workload } \\
\text { were influential in my decision to leave the } \\
\text { school. }\end{array}$} & Single & 170 & 148.41 \\
\hline & Married & 109 & 126.88 \\
\hline & Total & 279 & \\
\hline \multirow{3}{*}{$\begin{array}{l}\text { J. Communication between senior management } \\
\text { and faculty at the school was influential in my } \\
\text { decision to leave the school. }\end{array}$} & Single & 169 & 149.37 \\
\hline & Married & 109 & 124.20 \\
\hline & Total & 278 & \\
\hline \multirow{3}{*}{$\begin{array}{l}\text { K. The overall compensation package offered } \\
\text { to me was influential in my decision to leave the } \\
\text { school. }\end{array}$} & Single & 168 & 141.67 \\
\hline & Married & 109 & 134.89 \\
\hline & Total & 277 & \\
\hline \multirow{3}{*}{$\begin{array}{l}\text { L. Opportunities for leadership at the school } \\
\text { were influential in my decision to leave the } \\
\text { school. }\end{array}$} & Single & 169 & 139.67 \\
\hline & Married & 108 & 137.95 \\
\hline & Total & 277 & \\
\hline \multirow{3}{*}{$\begin{array}{l}\text { M. Teacher involvement in decision making at } \\
\text { the school was influential in my decision to } \\
\text { leave the school. }\end{array}$} & Single & 170 & 145.19 \\
\hline & Married & 108 & 130.55 \\
\hline & Total & 278 & \\
\hline \multirow{3}{*}{$\begin{array}{l}\text { N. A mismatch between my expectations } \\
\text { regarding the school and/or my role and the } \\
\text { reality when l arrived was influential in my } \\
\text { decision to leave the school. }\end{array}$} & Single & 168 & 145.63 \\
\hline & Married & 108 & 127.41 \\
\hline & Total & 276 & \\
\hline
\end{tabular}


O. Opportunities for professional advancement elsewhere were influential in my decision to leave the school.

\begin{tabular}{lll}
\hline Single & 169 & 143.94 \\
Married & 109 & 132.61 \\
Total & 278 & \\
Single & 169 & 137.95 \\
Married & 109 & 141.90 \\
Total & 278 & \\
Single & 170 & 145.79 \\
Married & 109 & 130.97 \\
Total & 279 & \\
Single & 170 & 148.32 \\
Married & 109 & 127.03 \\
Total & 279 & \\
\hline
\end{tabular}

Test Statistics by Marital Status(a,b)

A. The level of support from the principal and senior management at the school was influential in my decision to leave the school.

$B$. The quality of the induction program was influential in my decision to leave the school.

C. Resource support at the school (technological, print or otherwise) was influential in my decision to leave the school.

D. Student behavior at the school was influential in my decision to leave the school.

E. Parental support of teachers was influential in my decision to leave the school.

$F$. The quality of the school facility was influential in my decision to leave the school.

G. The academic standards of the school were influential in my decision to leave the school.

$\mathrm{H}$. The stability of my teaching assignment at the school was influential in my decision to leave the school.

I. Expectations regarding teacher workload were influential in my decision to leave the school.

$\mathrm{J}$. Communication between senior management and faculty at the school was influential in my decision to leave the school.

$K$. The overall compensation package offered to me was influential in my decision to leave the school.

L. Opportunities for leadership at the school were influential in my decision to leave the school.

$M$. Teacher involvement in decision making at the school was influential in my decision to leave the school.
Chi-Square

df

Asymp. Sig.

1.235

1

.266

7.068

1

.008

6.018

1

.014

.010

1

.581

1

.446

5.388

1

.445

1

.505

7.484

1

.006

5.075

1

.024

7.073

1

.008

.498

1

.481

.032

.858

2.313

.128 
N. A mismatch belween my expectations regarding the school and/or my role and the reality when I arrived was influential in my decision to leave the school.
3.625

4.861
.057

O. Opportunities for professional advancement elsewhere were influential in my decision to leave the school.

$P$. Personal circumstances were influential in my decision to leave the school.

Q. Living conditions in the host country were influential in my decision to leave the school.

R. The quality of my personal life while at the school was influential in my decision to leave the school.

a Kruskal Wallis Test

b Grouping Variable: Marital Status in the year in which you left:

\section{Mean Ranks by Children}

\begin{tabular}{|c|c|c|c|}
\hline \multirow{6}{*}{$\begin{array}{l}\text { A. The level of support from } \\
\text { the principal and senior } \\
\text { management at the school } \\
\text { was influential in my } \\
\text { decision to leave the } \\
\text { school. }\end{array}$} & $\begin{array}{l}\text { Number of children } \\
\text { living with you in the } \\
\text { year in which you left: }\end{array}$ & $N$ & Mean Rank \\
\hline & 0 & 224 & 138.34 \\
\hline & 1 & 28 & 154.91 \\
\hline & 2 & 20 & 117.13 \\
\hline & 3 & 4 & 139.38 \\
\hline & Total & 276 & \\
\hline \multirow{5}{*}{$\begin{array}{l}\text { B. The quality of the } \\
\text { induction program was } \\
\text { influential in my decision to } \\
\text { leave the school. }\end{array}$} & 0 & 224 & 140.11 \\
\hline & 1 & 29 & 145.17 \\
\hline & 2 & 20 & 117.65 \\
\hline & 3 & 4 & 138.88 \\
\hline & Total & 277 & \\
\hline \multirow{5}{*}{$\begin{array}{l}\text { C. Resource support at the } \\
\text { school (technological, print } \\
\text { or otherwise) was } \\
\text { influential in my decision to } \\
\text { leave the school. }\end{array}$} & 0 & 224 & 139.74 \\
\hline & 1 & 29 & 154.33 \\
\hline & 2 & 20 & 122.93 \\
\hline & 3 & 4 & 66.75 \\
\hline & Total & 277 & \\
\hline \multirow{5}{*}{$\begin{array}{l}\text { D. Student behavior at the } \\
\text { school was influential in my } \\
\text { decision to leave the } \\
\text { school. }\end{array}$} & 0 & 223 & 139.00 \\
\hline & 1 & 29 & 143.17 \\
\hline & 2 & 20 & 134.80 \\
\hline & 3 & 4 & 95.38 \\
\hline & Total & 276 & \\
\hline \multirow{4}{*}{$\begin{array}{l}\text { E. Parental support of } \\
\text { teachers was influential in } \\
\text { my decision to leave the } \\
\text { school. }\end{array}$} & 0 & 223 & 138.41 \\
\hline & 1 & 29 & 148.64 \\
\hline & 2 & 20 & 132.40 \\
\hline & 3 & 4 & 100.50 \\
\hline
\end{tabular}




\begin{tabular}{|c|c|c|c|}
\hline & Total & & \\
\hline & & 276 & \\
\hline \multirow{5}{*}{$\begin{array}{l}\text { F. The quality of the school } \\
\text { facility was influential in my } \\
\text { decision to leave the } \\
\text { school. }\end{array}$} & 0 & 225 & 141.26 \\
\hline & 1 & 29 & 136.50 \\
\hline & 2 & 19 & 130.34 \\
\hline & 3 & 4 & 71.25 \\
\hline & Total & 277 & \\
\hline \multirow{5}{*}{$\begin{array}{l}\text { G. The academic standards } \\
\text { of the school were } \\
\text { influential in my decision to } \\
\text { leave the school. }\end{array}$} & 0 & 224 & 137.86 \\
\hline & 1 & 28 & 162.50 \\
\hline & 2 & 20 & 127.53 \\
\hline & 3 & 4 & 61.25 \\
\hline & Total & 276 & \\
\hline \multirow{5}{*}{$\begin{array}{l}\text { H. The stability of my } \\
\text { teaching assignment at the } \\
\text { school was influential in my } \\
\text { decision to leave the } \\
\text { school. }\end{array}$} & 0 & 225 & 141.09 \\
\hline & 1 & 29 & 140.57 \\
\hline & 2 & 20 & 128.50 \\
\hline & 3 & 4 & 97.25 \\
\hline & Total & 278 & \\
\hline \multirow{5}{*}{$\begin{array}{l}\text { 1. Expectations regarding } \\
\text { teacher workload were } \\
\text { influential in my decision to } \\
\text { leave the school. }\end{array}$} & 0 & 225 & 142.41 \\
\hline & 1 & 29 & 134.76 \\
\hline & 2 & 20 & 105.48 \\
\hline & 3 & 4 & 180.25 \\
\hline & Total & 278 & \\
\hline \multirow{5}{*}{$\begin{array}{l}\text { J. Communication between } \\
\text { senior management and } \\
\text { faculty at the school was } \\
\text { influential in my decision to } \\
\text { leave the school. }\end{array}$} & 0 & 224 & 141.27 \\
\hline & 1 & 29 & 152.07 \\
\hline & 2 & 20 & 99.13 \\
\hline & 3 & 4 & 116.63 \\
\hline & Total & 277 & \\
\hline \multirow{5}{*}{$\begin{array}{l}\text { K. The overall } \\
\text { compensation package } \\
\text { offered to me was } \\
\text { influential in my decision to } \\
\text { leave the school. }\end{array}$} & 0 & 223 & 137.97 \\
\hline & 1 & 29 & 146.40 \\
\hline & 2 & 20 & 131.10 \\
\hline & 3 & 4 & 147.63 \\
\hline & Total & 276 & \\
\hline \multirow{5}{*}{$\begin{array}{l}\text { L. Opportunities for } \\
\text { leadership at the school } \\
\text { were influential in my } \\
\text { decision to leave the } \\
\text { school. }\end{array}$} & 0 & 224 & 140.49 \\
\hline & 1 & 29 & 125.09 \\
\hline & 2 & 19 & 146.58 \\
\hline & 3 & 4 & 85.88 \\
\hline & Total & 276 & \\
\hline \multirow{5}{*}{$\begin{array}{l}\text { M. Teacher involvement in } \\
\text { decision making at the } \\
\text { school was influential in my } \\
\text { decision to leave the } \\
\text { school. }\end{array}$} & 0 & 224 & 140.32 \\
\hline & 1 & 29 & 149.38 \\
\hline & 2 & 20 & 106.63 \\
\hline & 3 & 4 & 151.63 \\
\hline & Total & 277 & \\
\hline \multirow{3}{*}{$\begin{array}{l}\text { N. A mismatch between my } \\
\text { expectations regarding the } \\
\text { school and/or my role and }\end{array}$} & 0 & 222 & 142.40 \\
\hline & 1 & 29 & 142.40 \\
\hline & 2 & 20 & 84.63 \\
\hline
\end{tabular}




\begin{tabular}{llrr}
- the reality when I arrived & 3 & 4 & 128.63 \\
\cline { 2 - 4 } $\begin{array}{l}\text { was influential in my } \\
\text { decision to leave the }\end{array}$ & Total & 275 & \\
school. & & 224 & 144.19 \\
$\begin{array}{l}\text { O. Opportunities for } \\
\text { professional advancement }\end{array}$ & 1 & 29 & 131.29 \\
elsewhere were influential & 2 & 20 & 101.73 \\
in my decision to leave the & 3 & 4 & 90.50 \\
school. & 3 & 277 & \\
& Total & 224 & 138.12 \\
P. Personal circumstances & 0 & 29 & 135.52 \\
were influential in my & 1 & 20 & 146.00 \\
decision to leave the & 2 & 4 & 178.63 \\
school. & 3 & 277 & \\
& Total & 225 & 142.34 \\
Q. Living conditions in the & 0 & 29 & 123.33 \\
host country were & 1 & 20 & 131.05 \\
influential in my decision to & 2 & 4 & 139.25 \\
leave the school. & 3 & 278 & \\
& Total & 225 & 141.65 \\
R. The quality of my & 0 & 29 & 132.38 \\
personal life while at the & 1 & 20 & 121.15 \\
school was influential in my & 2 & 4 & 162.00 \\
decision to leave the & 3 & 278 & \\
school. & Total & & \\
\hline
\end{tabular}

Test Statistics by Children(a,b)

A. The level of support from the principal and senior management at the school was influential in my decision to leave the school.

$B$. The quality of the induction program was influential in my decision to leave the school.

C. Resource support at the school (technological, print or otherwise) was influential in my decision to leave the school.

D. Student behavior at the school was influential in my decision to leave the school.

E. Parental support of teachers was influential in my decision to leave the school.

$F$. The quality of the school facility was influential in my decision to leave the school.

$\mathrm{G}$. The academic standards of the school were influential in my decision to leave the school.

$\mathrm{H}$. The stability of my teaching assignment at the school was influential in my decision to leave the school.

I. Expectations regarding teacher workload were influential in my decision to leave the school.
Chi-Square

df

Asymp. Sig.

2.847

3

.416

1.775

3

.620

5.483

3

.140

1.541

3

.673

1.646

3

.649

3.510

3

.319

7.234

3

.065

1.729

3

.630

5.374

3

.146 
J. Communication between senior management and faculty at the school was influential in my decision to leave the school.

6.769

.545 influential in my decision to leave the school.

L. Opportunities for leadership at the school were influential in my decision to leave the school.

$M$. Teacher involvement in decision making at the school was influential in my decision to leave the school.

$\mathrm{N}$. A mismatch between my expectations regarding the school and/or my role and the reality when I arrived was influential in my decision to leave the school.

O. Opportunities for professional advancement elsewhere were influential in my decision to leave the school.

P. Personal circumstances were influential in my decision to leave the school. my decision to leave the school.

1.832

3

3

.080 influential in my decision to leave the school.

a Kruskal Wallis Test

b Grouping Variable: Number of children living with you in the year in which you left:

Mean Ranks by Experience in all schools

A. The level of support from the principal and senior management at the school was influential in my decision to leave the school.

B. The quality of the induction program was influential in my decision to leave the school.

C. Resource support at the school (technological, print or otherwise) was influential in my decision to leave the school.

\begin{tabular}{lrr}
$\begin{array}{l}\text { Including the year in } \\
\text { which you left, how many } \\
\text { total years of teaching } \\
\text { experience did you have }\end{array}$ & & \\
at THAT OR ANY & & \\
OTHER school? & $\mathrm{N}$ & Mean Rank \\
$0-4$ & 81 & 147.59 \\
$5-9$ & 71 & 134.83 \\
$10-14$ & 44 & 152.30 \\
$15-19$ & 30 & 113.90 \\
20 or more & 50 & 131.60 \\
Total & 276 & \\
$0-4$ & 80 & 149.29 \\
$5-9$ & 71 & 130.70 \\
$10-14$ & 44 & 146.30 \\
$15-19$ & 31 & 127.45 \\
20 or more & 51 & 135.15 \\
Total & 277 & \\
$0-4$ & 80 & 148.31 \\
$5-9$ & 71 & 145.52 \\
$10-14$ & 44 & 129.73 \\
$15-19$ & 31 & 122.29 \\
20 or more & 51 & 133.47 \\
\hline
\end{tabular}




\begin{tabular}{|c|c|c|c|}
\hline & Total & 277 & \\
\hline \multirow{6}{*}{$\begin{array}{l}\text { D. Student behavior at the } \\
\text { school was influential in my } \\
\text { decision to leave the } \\
\text { school. }\end{array}$} & $0-4$ & 80 & 147.96 \\
\hline & $5-9$ & 71 & 133.59 \\
\hline & $10-14$ & 44 & 137.48 \\
\hline & $15-19$ & 31 & 147.10 \\
\hline & 20 or more & 50 & 125.90 \\
\hline & Total & 276 & \\
\hline \multirow{6}{*}{$\begin{array}{l}\text { E. Parental support of } \\
\text { teachers was influential in } \\
\text { my decision to leave the } \\
\text { school. }\end{array}$} & $0-4$ & 79 & 138.87 \\
\hline & $5-9$ & 71 & 143.23 \\
\hline & $10-14$ & 44 & 133.70 \\
\hline & $15-19$ & 31 & 141.79 \\
\hline & 20 or more & 51 & 133.48 \\
\hline & Total & 276 & \\
\hline \multirow{7}{*}{$\begin{array}{l}\text { F. The quality of the school } \\
\text { facility was influential in my } \\
\text { decision to leave the } \\
\text { school. }\end{array}$} & $0-4$ & 81 & 145.38 \\
\hline & $5-9$ & 71 & 149.09 \\
\hline & $10-14$ & 43 & 124.00 \\
\hline & $15-19$ & 31 & 125.45 \\
\hline & 20 or more & 51 & 135.71 \\
\hline & Total & & \\
\hline & & 277 & \\
\hline \multirow{6}{*}{$\begin{array}{l}\text { G. The academic standards } \\
\text { of the school were } \\
\text { influential in my decision to } \\
\text { leave the school. }\end{array}$} & $0-4$ & 80 & 144.03 \\
\hline & $5-9$ & 71 & 143.53 \\
\hline & $10-14$ & 44 & 145.98 \\
\hline & $15-19$ & 31 & 122.95 \\
\hline & 20 or more & 50 & 125.58 \\
\hline & Total & 276 & \\
\hline \multirow{6}{*}{$\begin{array}{l}\text { H. The stability of my } \\
\text { teaching assignment at the } \\
\text { school was influential in my } \\
\text { decision to leave the } \\
\text { school. }\end{array}$} & $0-4$ & 82 & 147.77 \\
\hline & $5-9$ & 70 & 141.97 \\
\hline & $10-14$ & 44 & 140.42 \\
\hline & $15-19$ & 31 & 125.27 \\
\hline & 20 or more & 51 & 130.67 \\
\hline & Total & 278 & \\
\hline \multirow{6}{*}{$\begin{array}{l}\text { I. Expectations regarding } \\
\text { teacher workload were } \\
\text { influential in my decision to } \\
\text { leave the school. }\end{array}$} & $0-4$ & 81 & 131.59 \\
\hline & $5-9$ & 71 & 148.60 \\
\hline & $10-14$ & 44 & 138.92 \\
\hline & $15-19$ & 31 & 127.74 \\
\hline & 20 or more & 51 & 147.04 \\
\hline & Total & 278 & \\
\hline \multirow{5}{*}{$\begin{array}{l}\text { J. Communication between } \\
\text { senior management and } \\
\text { faculty at the school was } \\
\text { influential in my decision to } \\
\text { leave the school. }\end{array}$} & $0-4$ & 81 & 144.36 \\
\hline & $5-9$ & 71 & 139.89 \\
\hline & $10-14$ & 43 & 148.15 \\
\hline & $15-19$ & 31 & 131.02 \\
\hline & 20 or more & 51 & 126.39 \\
\hline
\end{tabular}




\begin{tabular}{|c|c|c|c|}
\hline & Total & 277 & \\
\hline \multirow{6}{*}{$\begin{array}{l}\text { K. The overall } \\
\text { compensation package } \\
\text { offered to me was } \\
\text { influential in my decision to } \\
\text { leave the school. }\end{array}$} & $0-4$ & 81 & 128.45 \\
\hline & $5 \cdot 9$ & 69 & 146.18 \\
\hline & $10-14$ & 44 & 120.06 \\
\hline & $15-19$ & 31 & 143.08 \\
\hline & 20 or more & 51 & 157.20 \\
\hline & Total & 276 & \\
\hline \multirow{6}{*}{$\begin{array}{l}\text { L. Opportunities for } \\
\text { leadership at the school } \\
\text { were influential in my } \\
\text { decision to leave the } \\
\text { school. }\end{array}$} & $0-4$ & 80 & 125.85 \\
\hline & $5-9$ & 71 & 134.65 \\
\hline & $10-14$ & 44 & 150.98 \\
\hline & $15-19$ & 30 & 130.92 \\
\hline & 20 or more & 51 & 157.40 \\
\hline & Total & 276 & \\
\hline \multirow{6}{*}{$\begin{array}{l}\text { M. Teacher involvement in } \\
\text { decision making at the } \\
\text { school was influential in my } \\
\text { decision to leave the } \\
\text { school. }\end{array}$} & $0-4$ & 81 & 140.73 \\
\hline & $5-9$ & 71 & 130.28 \\
\hline & $10-14$ & 44 & 141.88 \\
\hline & $15-19$ & 31 & 132.50 \\
\hline & 20 or more & 50 & 150.07 \\
\hline & Total & 277 & \\
\hline \multirow{6}{*}{$\begin{array}{l}\text { N. A mismatch between my } \\
\text { expectations regarding the } \\
\text { school and/or my role and } \\
\text { the reality when I arrived } \\
\text { was influential in my } \\
\text { decision to leave the } \\
\text { school. }\end{array}$} & $0-4$ & 80 & 134.74 \\
\hline & $5-9$ & 71 & 139.11 \\
\hline & $10-14$ & 44 & 142.39 \\
\hline & $15-19$ & 31 & 122.32 \\
\hline & 20 or more & 49 & 147.69 \\
\hline & Total & 275 & \\
\hline \multirow{6}{*}{$\begin{array}{l}\text { O. Opportunities for } \\
\text { professional advancement } \\
\text { elsewhere were influential } \\
\text { in my decision to leave the } \\
\text { school. }\end{array}$} & $0-4$ & 80 & 136.13 \\
\hline & $5-9$ & 71 & 155.39 \\
\hline & $10-14$ & 44 & 143.53 \\
\hline & $15-19$ & 31 & 123.27 \\
\hline & 20 or more & 51 & 126.32 \\
\hline & Total & 277 & \\
\hline \multirow{6}{*}{$\begin{array}{l}\text { P. Personal circumstances } \\
\text { were influential in my } \\
\text { decision to leave the } \\
\text { school. }\end{array}$} & $0-4$ & 81 & 140.31 \\
\hline & $5-9$ & 71 & 133.70 \\
\hline & $10-14$ & 44 & 135.69 \\
\hline & $15-19$ & 31 & 140.08 \\
\hline & 20 or more & 50 & 146.63 \\
\hline & Total & 277 & \\
\hline \multirow{6}{*}{$\begin{array}{l}\text { Q. Living conditions in the } \\
\text { host country were } \\
\text { influential in my decision to } \\
\text { leave the school. }\end{array}$} & $0-4$ & 81 & 146.77 \\
\hline & $5-9$ & 71 & 149.89 \\
\hline & $10-14$ & 44 & 123.57 \\
\hline & $15-19$ & 31 & 118.05 \\
\hline & 20 or more & 51 & 140.26 \\
\hline & Total & 278 & \\
\hline \multirow{4}{*}{$\begin{array}{l}\text { R. The quality of my } \\
\text { personal life while at the } \\
\text { school was influential in my } \\
\text { decision to leave the } \\
\text { school. }\end{array}$} & $0-4$ & 81 & 141.67 \\
\hline & $5-9$ & 71 & 142.79 \\
\hline & $10-14$ & 44 & 144.64 \\
\hline & $15-19$ & 31 & 129.89 \\
\hline
\end{tabular}




\begin{tabular}{lrr}
\hline 20 or more & 51 & 132.88 \\
Total & 278 & \\
\hline
\end{tabular}

\section{Test Statistics by Experience in all schools(a,b)}

A. The level of support from the principal and senior management at the school was influential in my decision to leave the school.

B. The quality of the induction program was influential in my decision to leave the school.

C. Resource support at the school (technological, print or otherwise) was influential in my decision to leave the school.

D. Student behavior at the school was influential in my decision to leave the school.

E. Parental support of teachers was influential in my decision to leave the school.

$F$. The quality of the school facility was influential in my decision to leave the school.

$G$. The academic standards of the school were influential in my decision to leave the school.

$H$. The stability of my teaching assignment at the school was influential in my decision to leave the school.

I. Expectations regarding teacher workload were influential in my decision to leave the school.

$\mathrm{J}$. Communication between senior management and faculty at the school was influential in my decision to leave the school.

K. The overall compensation package offered to me was influential in my decision to leave the school.

L. Opportunities for leadership at the school were influential in my decision to leave the school.

$M$. Teacher involvement in decision making at the school was influential in my decision to leave the school.

N. A mismatch between my expectations regarding the school and/or my role and the reality when I arrived was influential in my decision to leave the school.

O. Opportunities for professional advancement elsewhere were influential in my decision to leave the school.

P. Personal circumstances were influential in my decision to leave the school.

$Q$. Living conditions in the host country were influential in my decision to leave the school.

\section{Chi-Square}

3.483

df

Asymp. Sig.

6.247

4

4

3.982

4

3.513

4

.476

.733

4

.947

4.396

4

.355

3.832

4

.429

2.777

4

.596

3.010

4

2.729

4

.604

7.541

4

110

6.801

4

4

4

.673

5.996

4

4

6.160

4 
R. The quality of my personal life while at the school was influential in my decision to leave the school.

1.205

4

.877

a Kruskal Wallis Test

b Grouping Variable: Including the year in which you left, how many total years of teaching experience did you have at THAT OR ANY OTHER school?

\section{Mean Ranks by Experience in that school}

\begin{tabular}{|c|c|c|c|}
\hline & $\begin{array}{l}\text { Including the year in } \\
\text { which you left, how } \\
\text { many years had you } \\
\text { been at THAT school? }\end{array}$ & $N$ & Mean Rank \\
\hline \multirow{5}{*}{$\begin{array}{l}\text { A. The level of support from the } \\
\text { principal and senior management at } \\
\text { the school was influential in my } \\
\text { decision to leave the school. }\end{array}$} & 1 & 54 & 174.03 \\
\hline & 2 & 151 & 136.38 \\
\hline & 3 & 33 & 111.17 \\
\hline & 4 & 36 & 111.56 \\
\hline & Total & 274 & \\
\hline \multirow{5}{*}{$\begin{array}{l}\text { B. The quality of the induction } \\
\text { program was influential in my } \\
\text { decision to leave the school. }\end{array}$} & 1 & 54 & 178.29 \\
\hline & 2 & 151 & 132.29 \\
\hline & 3 & 34 & 125.38 \\
\hline & 4 & 36 & 113.42 \\
\hline & Total & 275 & \\
\hline \multirow{5}{*}{$\begin{array}{l}\text { C. Resource support at the school } \\
\text { (technological, print or otherwise) } \\
\text { was influential in my decision to } \\
\text { leave the school. }\end{array}$} & 1 & 54 & 151.68 \\
\hline & 2 & 151 & 141.27 \\
\hline & 3 & 34 & 126.24 \\
\hline & 4 & 36 & 114.89 \\
\hline & Total & 275 & \\
\hline \multirow{5}{*}{$\begin{array}{l}\text { D. Student behavior at the school } \\
\text { was influential in my decision to } \\
\text { leave the school. }\end{array}$} & 1 & 53 & 160.56 \\
\hline & 2 & 151 & 137.06 \\
\hline & 3 & 34 & 122.32 \\
\hline & 4 & 36 & 119.74 \\
\hline & Total & 274 & \\
\hline \multirow{6}{*}{$\begin{array}{l}\text { E. Parental support of teachers was } \\
\text { influential in my decision to leave the } \\
\text { school. }\end{array}$} & 1 & 54 & 158.81 \\
\hline & 2 & 151 & 133.91 \\
\hline & 3 & 33 & 131.71 \\
\hline & 4 & 36 & 125.90 \\
\hline & Total & & \\
\hline & & 274 & \\
\hline \multirow{5}{*}{$\begin{array}{l}\text { F. The quality of the school facility } \\
\text { was influential in my decision to } \\
\text { leave the school. }\end{array}$} & 1 & 54 & 147.60 \\
\hline & 2 & 152 & 149.93 \\
\hline & 3 & 34 & 107.01 \\
\hline & 4 & 35 & 101.49 \\
\hline & Total & 275 & \\
\hline G. The academic standards of the & 1 & 54 & 173.41 \\
\hline
\end{tabular}




\begin{tabular}{|c|c|c|c|}
\hline \multirow{4}{*}{$\begin{array}{l}\text { school were influential in my decision } \\
\text { to leave the school. }\end{array}$} & 2 & 150 & 135.42 \\
\hline & 3 & 34 & 121.74 \\
\hline & 4 & 36 & 107.19 \\
\hline & Total & 274 & \\
\hline \multirow{5}{*}{$\begin{array}{l}\mathrm{H} \text {. The stability of my teaching } \\
\text { assignment at the school was } \\
\text { influential in my decision to leave the } \\
\text { school. }\end{array}$} & 1 & 54 & 165.05 \\
\hline & 2 & 151 & 133.80 \\
\hline & 3 & 34 & 133.07 \\
\hline & 4 & 37 & 123.92 \\
\hline & Total & 276 & \\
\hline \multirow{5}{*}{$\begin{array}{l}\text { I. Expectations regarding teacher } \\
\text { workload were influential in my } \\
\text { decision to leave the school. }\end{array}$} & 1 & 54 & 159.75 \\
\hline & 2 & 151 & 131.13 \\
\hline & 3 & 34 & 146.26 \\
\hline & 4 & 37 & 130.42 \\
\hline & Total & 276 & \\
\hline \multirow{5}{*}{$\begin{array}{l}\text { J. Communication between senior } \\
\text { management and faculty at the } \\
\text { school was influential in my decision } \\
\text { to leave the school. }\end{array}$} & 1 & 53 & 162.31 \\
\hline & 2 & 152 & 135.73 \\
\hline & 3 & 34 & 132.79 \\
\hline & 4 & 36 & 116.69 \\
\hline & Total & 275 & \\
\hline \multirow{5}{*}{$\begin{array}{l}\text { K. The overall compensation } \\
\text { package offered to me was influential } \\
\text { in my decision to leave the school. }\end{array}$} & 1 & 54 & 126.40 \\
\hline & 2 & 149 & 142.23 \\
\hline & 3 & 34 & 146.84 \\
\hline & 4 & 37 & 126.08 \\
\hline & Total & 274 & \\
\hline \multirow{5}{*}{$\begin{array}{l}\text { L. Opportunities for leadership at the } \\
\text { school were influential in my decision } \\
\text { to leave the school. }\end{array}$} & 1 & 54 & 140.90 \\
\hline & 2 & 151 & 135.18 \\
\hline & 3 & 34 & 131.21 \\
\hline & 4 & 35 & 148.37 \\
\hline & Total & 274 & \\
\hline \multirow{5}{*}{$\begin{array}{l}\text { M. Teacher involvement in decision } \\
\text { making at the school was influential } \\
\text { in my decision to leave the school. }\end{array}$} & 1 & 54 & 149.05 \\
\hline & 2 & 151 & 137.78 \\
\hline & 3 & 34 & 130.46 \\
\hline & 4 & 36 & 129.47 \\
\hline & Total & 275 & \\
\hline \multirow{5}{*}{$\begin{array}{l}\text { N. A mismatch between my } \\
\text { expectations regarding the school } \\
\text { and/or my role and the reality when I } \\
\text { arrived was influential in my decision } \\
\text { to leave the school. }\end{array}$} & 1 & 54 & 183.05 \\
\hline & 2 & 149 & 128.99 \\
\hline & 3 & 34 & 120.65 \\
\hline & 4 & 36 & 116.54 \\
\hline & Total & 273 & \\
\hline \multirow{5}{*}{$\begin{array}{l}\text { O. Opportunities for professional } \\
\text { advancement elsewhere were } \\
\text { influential in my decision to leave the } \\
\text { school. }\end{array}$} & 1 & 54 & 116.72 \\
\hline & 2 & 151 & 150.06 \\
\hline & 3 & 34 & 130.19 \\
\hline & 4 & 36 & 126.71 \\
\hline & Total & 275 & \\
\hline \multirow{3}{*}{$\begin{array}{l}\text { P. Personal circumstances were } \\
\text { influential in my decision to leave the } \\
\text { school. }\end{array}$} & 1 & 54 & 127.29 \\
\hline & 2 & 150 & 140.43 \\
\hline & 3 & 34 & 123.79 \\
\hline
\end{tabular}




\begin{tabular}{llrr}
\cline { 2 - 4 } & 4 & 37 & 156.84 \\
& Total & 275 & \\
Q. Living conditions in the host & 1 & 54 & 129.19 \\
country were influential in my & 2 & 151 & 151.12 \\
decision to leave the school. & 3 & 34 & 115.35 \\
& 4 & 37 & 121.85 \\
& Total & 276 & \\
R. The quality of my personal life & 1 & 54 & 146.67 \\
while at the school was influential in & 2 & 151 & 140.95 \\
my decision to leave the school. & 3 & 34 & 126.54 \\
& 4 & 37 & 127.58 \\
& Total & 276 & \\
\hline
\end{tabular}

Test Statistics by Experience in that school $(a, b)$

A. The level of support from the principal and senior management at the school was influential in my decision to leave the school.

$B$. The quality of the induction program was influential in my decision to leave the school.

C. Resource support at the school (technological, print or otherwise) was influential in my decision to leave the school.

D. Student behavior at the school was influential in my decision to leave the school.

E. Parental support of teachers was influential in my decision to leave the school.

$F$. The quality of the school facility was influential in my decision to leave the school.

G. The academic standards of the school were influential in my decision to leave the school.

$\mathrm{H}$. The stability of my teaching assignment at the school was influential in my decision to leave the school.

I. Expectations regarding teacher workload were influential in my decision to leave the school.

$\mathrm{J}$. Communication between senior management and faculty at the school was influential in my decision to leave the school.

$K$. The overall compensation package offered to me was influential in my decision to leave the school.

L. Opportunities for leadership at the school were influential in my decision to leave the school.

\section{Chi-Square}

20.724

20.558

6.010

8.819

5.694

17.865

19.293

8.668

6.232

3

8.509

3

2.976

3

1.175
.037

.395

Asymp. Sig.

.000

.000

.000

.000

.034

101 


\begin{tabular}{l}
$\begin{array}{l}\text { M. Teacher involvement in decision making at the } \\
\text { school was influential in my decision to leave the } \\
\text { school. }\end{array}$ \\
$\begin{array}{l}\text { N. A mismatch between my expectations } \\
\text { regarding the school and/or my role and the } \\
\text { reality when I arrived was influential in my } \\
\text { decision to leave the school. }\end{array}$ \\
$\begin{array}{l}\text { O. Opportunities for professional advancement } \\
\text { elsewhere were influential in my decision to leave } \\
\text { the school. }\end{array}$ \\
$\begin{array}{l}\text { P. Personal circumstances were influential in my } \\
\text { decision to leave the school. }\end{array}$ \\
$\begin{array}{l}\text { Q. Living conditions in the host country were } \\
\text { influential in my decision to leave the school. }\end{array}$ \\
$\begin{array}{l}\text { R. The quality of my personal life while at the } \\
\text { school was influential in my decision to leave the } \\
\text { school. }\end{array}$ \\
\hline
\end{tabular}

a Kruskal Wallis Test

b Grouping Variable: Including the year in which you left, how many years had you been at THAT school?

Mean Ranks by Experience in international schools

\begin{tabular}{|c|c|c|c|}
\hline & $\begin{array}{l}\text { Including the year in which } \\
\text { you left, how many years } \\
\text { had you taught at } \\
\text { international schools? }\end{array}$ & $N$ & Mean Rank \\
\hline \multirow{6}{*}{$\begin{array}{l}\text { A. The level of support from } \\
\text { the principal and senior } \\
\text { management at the school } \\
\text { was influential in my } \\
\text { decision to leave the } \\
\text { school. }\end{array}$} & $0-4$ & 147 & 140.45 \\
\hline & $5-9$ & 71 & 128.98 \\
\hline & $10-14$ & 31 & 153.08 \\
\hline & $15-19$ & 12 & 112.08 \\
\hline & 20 or more & 14 & 146.89 \\
\hline & Total & 275 & \\
\hline \multirow{6}{*}{$\begin{array}{l}\text { B. The quality of the } \\
\text { induction program was } \\
\text { influential in my decision to } \\
\text { leave the school. }\end{array}$} & $0-4$ & 147 & 144.44 \\
\hline & $5-9$ & 70 & 132.90 \\
\hline & $10-14$ & 32 & 130.89 \\
\hline & $15-19$ & 13 & 120.23 \\
\hline & 20 or more & 14 & 138.46 \\
\hline & Total & 276 & \\
\hline \multirow{6}{*}{$\begin{array}{l}\text { C. Resource support at the } \\
\text { school (technological, print } \\
\text { or otherwise) was } \\
\text { influential in my decision to } \\
\text { leave the school. }\end{array}$} & 0.4 & 147 & 152.04 \\
\hline & $5-9$ & 70 & 123.12 \\
\hline & $10-14$ & 32 & 113.78 \\
\hline & $15-19$ & 13 & 132.19 \\
\hline & 20 or more & 14 & 135.57 \\
\hline & Total & 276 & \\
\hline \multirow{4}{*}{$\begin{array}{l}\text { D. Student behavior at the } \\
\text { school was influential in my } \\
\text { decision to leave the } \\
\text { school. }\end{array}$} & $0-4$ & 147 & 138.85 \\
\hline & $5-9$ & 70 & 134.04 \\
\hline & $10-14$ & 32 & 136.97 \\
\hline & $15-19$ & 13 & 146.81 \\
\hline
\end{tabular}




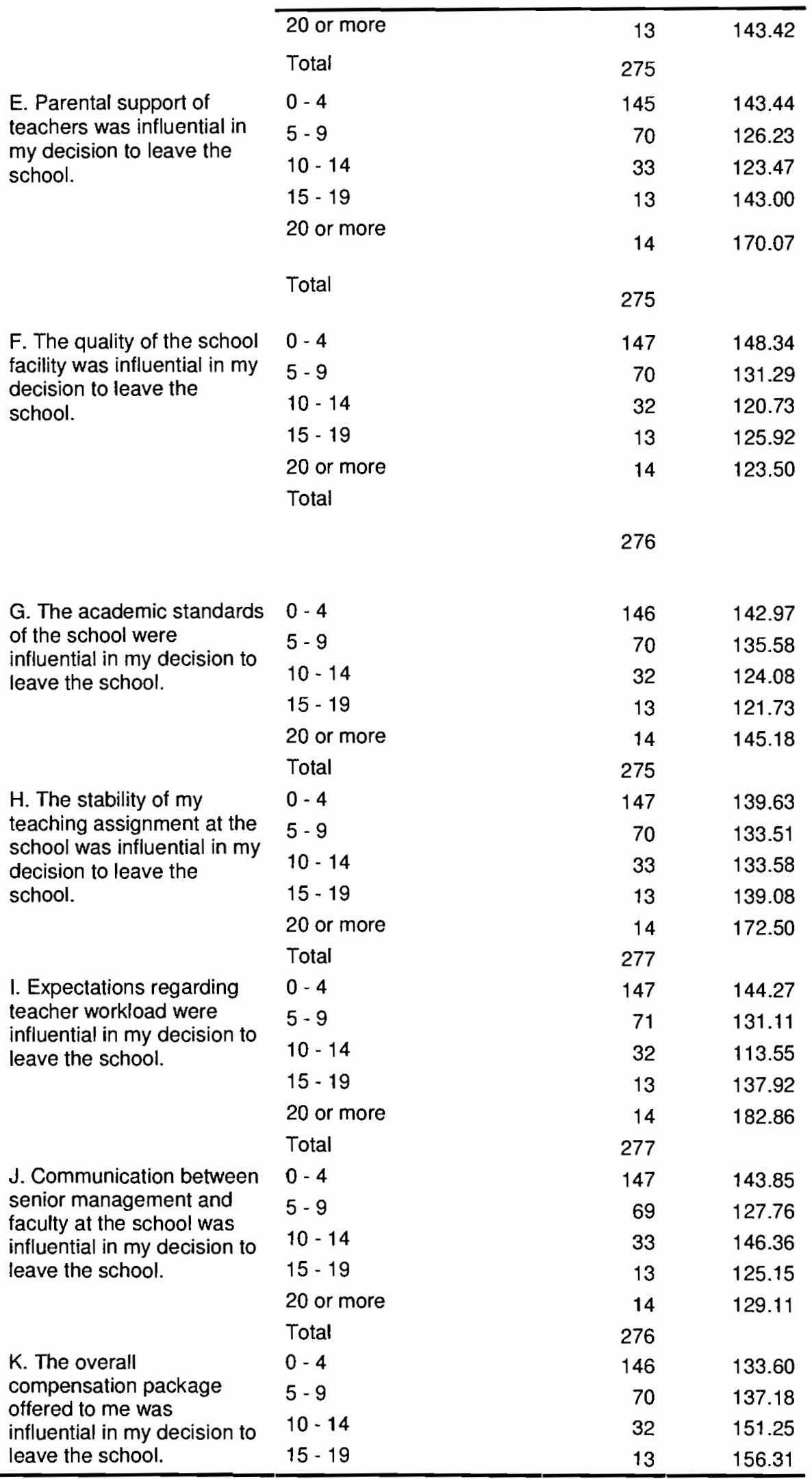




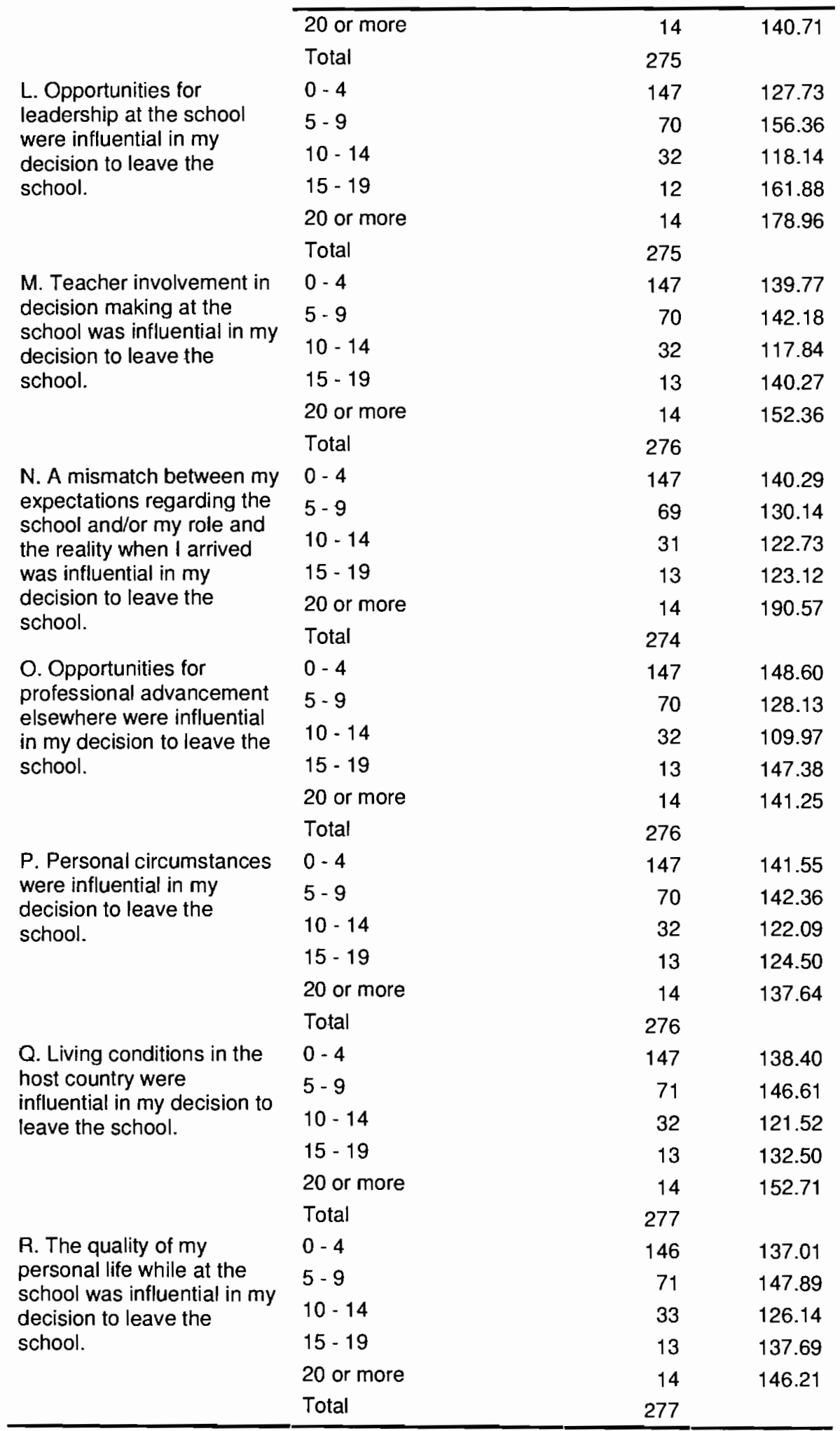


Test Statistics by Experience in international schools(a,b)

A. The level of support from the principal and senior management at the school was

Chi-Square

$B$. The quality of the induction program was influential in my decision to leave the school.

C. Resource support at the school (technological, print or otherwise) was influential in my decision to leave the school.

D. Student behavior at the school was influential in my decision to leave the school.

E. Parental support of teachers was influential in my decision to leave the school.

$F$. The quality of the school facility was influential in my decision to leave the school.

$G$. The academic standards of the school were influential in my decision to leave the school.

$H$. The stability of my teaching assignment at the school was influential in my decision to leave the school.

1. Expectations regarding teacher workload were influential in my decision to leave the school.

J. Communication between senior management and faculty at the school was influential in my decision to leave the school.

$K$. The overall compensation package offered to me was influential in my decision to leave the school.

L. Opportunities for leadership at the school were influential in my decision to leave the school.

$M$. Teacher involvement in decision making at the school was influential in my decision to leave the school.

N. A mismatch between my expectations regarding the school and/or my role and the reality when I arrived was influential in my decision to leave the school.

O. Opportunities for professional advancement elsewhere were influential in my decision to leave the school.

$P$. Personal circumstances were influential in my decision to leave the school.

$\mathrm{Q}$. Living conditions in the host country were influential in my decision to leave the school.

R. The quality of my personal life while at the school was influential in my decision to leave the school.
3.939

2.311

df

Asymp. Sig.

4

.031

.487

4

6.224

4

5.555

4

2.462

4

.651

3.233

4

.520

9.379

4

.052

3.039

4

.551

2.154

4

.708

13.832

4

.008

2.910

4

.573

9.067

4

.059

8.227

4

.084

2.243

4

.691

2.841

4

.585

2.033 
a Kruskal Wallis Test

b Grouping Variable: Including the year in which you left, how many years had you taught at international schools?

\section{Mean Ranks by Subject area}

B. The quality of the induction program was influential in my decision to leave the school.

A. The level of support from the principal and senior management at the school was influential in my decision to leave the school.

C. Resource support at the school (technological, print or otherwise) was influential in my decision to leave the school.

D. Student behavior at the school was influential in my decision to leave the school.

E. Parental support of teachers was influential in my decision to leave the school.

\section{Main subject area of \\ teaching:}

Elementary generalist

Math/science

Humanities

Special Education

English as a Second

Language

Other subject specialist

Total

Elementary generalist

Math/science

Humanities

Special Education

English as a Second

Language

Other subject specialist

Total

Elementary generalist

Math/science

Humanities

Special Education

English as a Second

Language

Other subject specialist

Total

Elementary generalist

Math/science

Humanities

Special Education

English as a Second

Language

Other subject specialist

Total

Elementary generalist

Math/science

Humanities

Special Education

English as a Second

Language

Other subject specialist

Total

\begin{tabular}{|c|c|}
\hline$N$ & Mean Rank \\
\hline 80 & 130.86 \\
\hline 51 & 144.94 \\
\hline 44 & 139.18 \\
\hline 9 & 147.11 \\
\hline 13 & 152.38 \\
\hline 78 & 136.67 \\
\hline 275 & \\
\hline 80 & 151.40 \\
\hline 52 & 137.55 \\
\hline 45 & 138.97 \\
\hline 9 & 169.17 \\
\hline 13 & 123.38 \\
\hline 77 & 124.44 \\
\hline 276 & \\
\hline 80 & 149.23 \\
\hline 52 & 139.50 \\
\hline 45 & 135.52 \\
\hline 9 & 150.28 \\
\hline 13 & 122.27 \\
\hline 77 & 129.79 \\
\hline 276 & \\
\hline 80 & 128.48 \\
\hline 52 & 151.30 \\
\hline 45 & 142.24 \\
\hline 9 & 111.11 \\
\hline 13 & 163.46 \\
\hline 76 & 135.24 \\
\hline 275 & \\
\hline 80 & 132.30 \\
\hline 52 & 130.79 \\
\hline 44 & 133.38 \\
\hline 9 & 129.78 \\
\hline 13 & 138.50 \\
\hline 77 & 152.31 \\
\hline 275 & \\
\hline
\end{tabular}


$F$. The quality of the school facility was influential in my decision to leave the school.

\begin{tabular}{lrr}
\hline Elementary generalist & 80 & 145.94 \\
Math/science & 52 & 147.33 \\
Humanities & 44 & 139.82 \\
Special Education & 9 & 127.61 \\
English as a Second & 13 & 113.81 \\
Language & & \\
Other subject specialist & 78 & 129.62
\end{tabular}

Total

276

Elementary generalist

Math/science

$80 \quad 143.01$ of the school were influential in my decision to leave the school.

$52 \quad 151.36$

$45 \quad 127.93$
Humanities

Special Education

English as a Second

Language

Other subject specialist

Total
$9 \quad 136.17$

$13 \quad 156.35$

$76 \quad 126.63$

275

$H$. The stability of my teaching assignment at the school was influential in my decision to leave the school.

Elementary generalist

133.36

Math/science

80

$\begin{array}{ll}52 & 140.45 \\ 44 & 144.07\end{array}$

Humanities

Special Education

English as a Second

Language

$9 \quad 134.17$

Other subject specialist

131.35

Total

142.74

Elementary generalist

Math/science

13

79

277

1. Expectations regarding teacher workload were influential in my decision to leave the school.

Humanities

80

129.58

52

150.64

Special Education

45

132.21

English as a Second

Language

153.06

Other subject specialist

153.50

Total

140.78

Elementary generalist

136.73

J. Communication between senior management and faculty at the school was influential in my decision to leave the school.

Math/science

Humanities

Special Education

English as a Second

Language

Other subject specialist

Total

137.60

143.26

$\begin{array}{ll}9 & 133.17\end{array}$

$13 \quad 151.19$

$77 \quad 136.66$

Elementary generalist

276

$K$. The overall compensation package offered to me was
79

52

44
129.64

146.61

144.51 
influential in my decision to leave the school.

L. Opportunities for leadership at the school were influential in my decision to leave the school.

\begin{tabular}{|c|c|c|}
\hline Special Education & 9 & 159.89 \\
\hline $\begin{array}{l}\text { English as a Second } \\
\text { Language }\end{array}$ & 13 & 156.27 \\
\hline Other subject specialist & 78 & 131.49 \\
\hline Total & 275 & \\
\hline Elementary generalist & 80 & 131.69 \\
\hline Math/science & 52 & 142.91 \\
\hline Humanities & 44 & 146.85 \\
\hline Special Education & 9 & 180.83 \\
\hline $\begin{array}{l}\text { English as a Second } \\
\text { Language }\end{array}$ & 13 & 143.12 \\
\hline Other subject specialist & 77 & 130.31 \\
\hline Total & 275 & \\
\hline Elementary generalist & 79 & 131.02 \\
\hline Math/science & 52 & 137.79 \\
\hline Humanities & 45 & 139.22 \\
\hline Special Education & 9 & 161.56 \\
\hline $\begin{array}{l}\text { English as a Second } \\
\text { Language }\end{array}$ & 13 & 138.54 \\
\hline Other subject specialist & 78 & 143.47 \\
\hline Total & 276 & \\
\hline Elementary generalist & 80 & 136.26 \\
\hline Math/science & 50 & 140.12 \\
\hline Humanities & 45 & 136.43 \\
\hline Special Education & 9 & 154.44 \\
\hline $\begin{array}{l}\text { English as a Second } \\
\text { Language }\end{array}$ & 13 & 126.15 \\
\hline Other subject specialist & 77 & 137.64 \\
\hline Total & 274 & \\
\hline Elementary generalist & 80 & 151.56 \\
\hline Math/science & 52 & 134.65 \\
\hline Humanities & 45 & 120.23 \\
\hline Special Education & 9 & 159.72 \\
\hline $\begin{array}{l}\text { English as a Second } \\
\text { Language }\end{array}$ & 13 & 140.50 \\
\hline Other subject specialist & 77 & 135.39 \\
\hline Total & 276 & \\
\hline Elementary generalist & 80 & 137.88 \\
\hline Math/science & 52 & 137.79 \\
\hline Humanities & 45 & 147.40 \\
\hline Special Education & 9 & 137.22 \\
\hline $\begin{array}{l}\text { English as a Second } \\
\text { Language }\end{array}$ & 12 & 128.33 \\
\hline Other subject specialist & 78 & 136.19 \\
\hline Total & 276 & \\
\hline Elementary generalist & 80 & 147.25 \\
\hline Math/science & 52 & 136.59 \\
\hline Humanities & 45 & 140.87 \\
\hline
\end{tabular}

$\mathrm{N}$. A mismatch between $\mathrm{my}$ expectations regarding the school and/or my role and the reality when I arrived was influential in my decision to leave the school.

O. Opportunities for professional advancement elsewhere were influential in my decision to leave the school.

P. Personal circumstances were influential in my decision to leave the school.

Q. Living conditions in the host country were

influential in my decision to

$M$. Teacher involvement in decision making at the on to leave the 


\begin{tabular}{lrrr}
\hline leave the school. & Special Education & 9 & 151.94 \\
& English as a Second & 13 & 109.08 \\
& Language & 78 & 134.56 \\
& Other subject specialist & 277 & \\
& Total & 80 & 139.34 \\
& Elementary generalist & 52 & 135.57 \\
R. The quality of my & Math/science & 45 & 144.99 \\
personal life while at the & Humool was influential in my & 9 & 129.83 \\
decision to leave the & Special Education & 12 & 119.50 \\
school. & English as a Second & 79 & 141.51 \\
& Language & 277 & \\
\hline & Other subject specialist & & \\
& Total & &
\end{tabular}

Test Statistics by Subject area(a,b)

A. The level of support from the principal and senior management at the school was influential in my decision to leave the school.

$B$. The quality of the induction program was influential in my decision to leave the school.

C. Resource support at the school (technological, print or otherwise) was influential in my decision to leave the school.

D. Student behavior at the school was influential in my decision to leave the school.

E. Parental support of teachers was influential in my decision to leave the school.

$F$. The quality of the school facility was influential in my decision to leave the school.

G. The academic standards of the school were influential in my decision to leave the school.

$H$. The stability of my teaching assignment at the school was influential in my decision to leave the school.

1. Expectations regarding teacher workload were influential in my decision to leave the school.

$\mathrm{J}$. Communication between senior management and faculty at the school was influential in my decision to leave the school.

$K$. The overall compensation package offered to me was influential in my decision to leave the school.

L. Opportunities for leadership at the school were influential in my decision to leave the school.

\section{Chi-Square}

$\mathrm{d} f$

Asymp. Sig.

1.751

5

.882

6.835

5

3.378

5

.642

6.050

5

.301

3.945

5

3.970

5

.554

5.152

5

.398

1.004

5

.962

3.503

5

.623

.671

5

.985

3.856

5

.570

4.939

5 
$M$. Teacher involvement in decision making at the school was influential in my decision to leave the school.

1.852

5

.869

$N$. A mismatch between my expectations regarding the school and/or my role and the reality when I arrived was influential in my decision to leave the school.

O. Opportunities for professional advancement elsewhere were influential in my decision to leave the school.

5.670

$P$. Personal circumstances were influential in my decision to leave the school.

Q. Living conditions in the host country were influential in my decision to leave the school.

$R$. The quality of my personal life while at the school was influential in my decision to leave the school.

a Kruskal Wallis Test

b Grouping Variable: Main subject area of teaching:

\section{Mean Ranks by Level of education}

\begin{tabular}{|c|c|c|c|}
\hline \multirow{5}{*}{$\begin{array}{l}\text { A. The level of support from } \\
\text { the principal and senior } \\
\text { management at the school } \\
\text { was influential in my } \\
\text { decision to leave the } \\
\text { school. }\end{array}$} & $\begin{array}{l}\text { Highest degree you had } \\
\text { earned in the year in } \\
\text { which you left? }\end{array}$ & $N$ & Mean Rank \\
\hline & Bachelor's & 132 & 142.65 \\
\hline & Master's & 100 & 143.65 \\
\hline & $\begin{array}{l}\text { Specialist or } \\
\text { professional diploma }\end{array}$ & 34 & 112.85 \\
\hline & $\begin{array}{l}\text { Doctorate or } \\
\text { professional degree }\end{array}$ & 10 & 119.45 \\
\hline \multirow{4}{*}{$\begin{array}{l}\text { B. The quality of the } \\
\text { induction program was } \\
\text { influential in my decision to } \\
\text { leave the school. }\end{array}$} & Total & 276 & \\
\hline & Bachelor's & 132 & 141.61 \\
\hline & Master's & 100 & 143.16 \\
\hline & $\begin{array}{l}\text { Specialist or } \\
\text { professional diploma }\end{array}$ & 34 & 117.88 \\
\hline \multirow{6}{*}{$\begin{array}{l}\text { C. Resource support at the } \\
\text { school (technological, print } \\
\text { or otherwise) was } \\
\text { influential in my decision to } \\
\text { leave the school. }\end{array}$} & $\begin{array}{l}\text { Doctorate or } \\
\text { professional degree }\end{array}$ & 11 & 135.09 \\
\hline & Total & 277 & \\
\hline & Bachelor's & 132 & 137.25 \\
\hline & Master's & 100 & 141.81 \\
\hline & $\begin{array}{l}\text { Specialist or } \\
\text { professional diploma }\end{array}$ & 34 & 140.90 \\
\hline & $\begin{array}{l}\text { Doctorate or } \\
\text { professional degree }\end{array}$ & 11 & 128.64 \\
\hline \multirow{4}{*}{$\begin{array}{l}\text { D. Student behavior at the } \\
\text { school was influential in my } \\
\text { decision to leave the } \\
\text { school. }\end{array}$} & Total & 277 & \\
\hline & Bachelor's & 132 & 133.77 \\
\hline & Master's & 99 & 154.56 \\
\hline & $\begin{array}{l}\text { Specialist or } \\
\text { professional diploma }\end{array}$ & 34 & 110.24 \\
\hline
\end{tabular}


E. Parental support of teachers was influential in my decision to leave the school.

\begin{tabular}{lrr}
\hline $\begin{array}{l}\text { Doctorate or } \\
\text { professional degree }\end{array}$ & 11 & 138.09 \\
Total & 276 & \\
$\begin{array}{l}\text { Bachelor's } \\
\text { Master's }\end{array}$ & 132 & 138.30 \\
$\begin{array}{l}\text { Specialist or } \\
\text { professional diploma }\end{array}$ & 99 & 147.40 \\
$\begin{array}{l}\text { Doctorate or } \\
\text { professional degree }\end{array}$ & 34 & 121.49 \\
Total & 11 & 113.45
\end{tabular}

276

$F$. The quality of the school facility was influential in my decision to leave the school.

Bachelor's

132

144.72

Master's

100

133.37

Specialist or

professional diploma

34

135.26

Doctorate or

professional degree

133.14

Total

135.17

Bachelor's

277

131

100

142.48

of the school were influential in my decision to leave the school.

Specialist or
professional

professional diploma

$34 \quad 131.68$

Doctorate or

professional degree

163.05

Total

276

Bachelor's

132

101

140.20

Master's

Specialist or

professional diploma

143.00

school was influential in my school.

Doctorate or

professional degree

126.06

Total

140.41

Bachelor's

Master's

Specialist or

professional diploma

142.29

101

143.48

influential in my decision to leave the school.

Doctorate or

professional degree

112.24

Total

$11 \quad 153.82$

278

132

137.75

100

146.45

Master's

34

120.93

professional diploma

11

142.23

professional degree 
$K$. The overall compensation package offered to me was influential in my decision to leave the school.

L. Opportunities for leadership at the school were influential in my decision to leave the school.

$M$. Teacher involvement in decision making at the school was influential in my decision to leave the school.

N. A mismatch between my expectations regarding the school and/or my role and the reality when I arrived was influential in my decision to leave the school.

O. Opportunities for professional advancement elsewhere were influential in my decision to leave the school.

P. Personal circumstances were influential in my decision to leave the school.

Q. Living conditions in the host country were influential in my decision to leave the school.

\begin{tabular}{|c|c|c|}
\hline Bachelor's & 130 & 138.41 \\
\hline Master's & 101 & 140.00 \\
\hline $\begin{array}{l}\text { Specialist or } \\
\text { professional diploma }\end{array}$ & 34 & 127.13 \\
\hline $\begin{array}{l}\text { Doctorate or } \\
\text { professional degree }\end{array}$ & 11 & 160.95 \\
\hline Total & 276 & \\
\hline Bachelor's & 132 & 138.94 \\
\hline Master's & 99 & 142.91 \\
\hline $\begin{array}{l}\text { Specialist or } \\
\text { professional diploma }\end{array}$ & 34 & 111.69 \\
\hline $\begin{array}{l}\text { Doctorate or } \\
\text { professional degree }\end{array}$ & 11 & 176.41 \\
\hline Total & 276 & \\
\hline Bachelor's & 133 & 144.04 \\
\hline Master's & 99 & 139.08 \\
\hline $\begin{array}{l}\text { Specialist or } \\
\text { professional diploma }\end{array}$ & 34 & 112.76 \\
\hline $\begin{array}{l}\text { Doctorate or } \\
\text { professional degree }\end{array}$ & 11 & 158.45 \\
\hline Total & 277 & \\
\hline Bachelor's & 131 & 134.56 \\
\hline Master's & 99 & 150.69 \\
\hline $\begin{array}{l}\text { Specialist or } \\
\text { professional diploma }\end{array}$ & 34 & 117.43 \\
\hline $\begin{array}{l}\text { Doctorate or } \\
\text { professional degree }\end{array}$ & 11 & 128.32 \\
\hline Total & 275 & \\
\hline Bachelor's & 132 & 146.06 \\
\hline Master's & 100 & 138.56 \\
\hline $\begin{array}{l}\text { Specialist or } \\
\text { professional diploma }\end{array}$ & 34 & 114.79 \\
\hline $\begin{array}{l}\text { Doctorate or } \\
\text { professional degree }\end{array}$ & 11 & 133.05 \\
\hline Total & 277 & \\
\hline Bachelor's & 132 & 139.00 \\
\hline Master's & 100 & 129.38 \\
\hline $\begin{array}{l}\text { Specialist or } \\
\text { professional diploma }\end{array}$ & 34 & 159.21 \\
\hline $\begin{array}{l}\text { Doctorate or } \\
\text { professional degree }\end{array}$ & 11 & 164.00 \\
\hline Total & 277 & \\
\hline Bachelor's & 132 & 142.27 \\
\hline Master's & 101 & 138.03 \\
\hline $\begin{array}{l}\text { Specialist or } \\
\text { professional diploma }\end{array}$ & 34 & 141.56 \\
\hline $\begin{array}{l}\text { Doctorate or } \\
\text { professional degree }\end{array}$ & 11 & 113.41 \\
\hline Total & 278 & \\
\hline
\end{tabular}




\begin{tabular}{llrr}
$\begin{array}{l}\text { R. The quality of my } \\
\text { personal life while at the } \\
\text { school was influential in my } \\
\text { decision to leave the }\end{array}$ & $\begin{array}{l}\text { Machelor's } \\
\text { school. }\end{array}$ & 132 & 138.86 \\
& $\begin{array}{l}\text { Specialist or } \\
\text { professional diploma }\end{array}$ & 34 & 141.91 \\
& $\begin{array}{l}\text { Doctorate or } \\
\text { professional degree }\end{array}$ & 11 & 167.23 \\
& Total & 278 \\
\hline
\end{tabular}

Test Statistics by Level of education(a,b)

A. The level of support from the principal and senior management at the school was influential in my decision to leave the school.

$B$. The quality of the induction program was influential in my decision to leave the school.

C. Resource support at the school (technological, print or otherwise) was influential in my decision to leave the school.

D. Student behavior at the school was influential in my decision to leave the school.

E. Parental support of teachers was influential in my decision to leave the school.

$F$. The quality of the school facility was influential in my decision to leave the school.

G. The academic standards of the school were influential in my decision to leave the school.

$\mathrm{H}$. The stability of my teaching assignment at the school was influential in my decision to leave the school.

1. Expectations regarding teacher workload were influential in my decision to leave the school.

J. Communication between senior management and faculty at the school was influential in my decision to leave the school.

$K$. The overall compensation package offered to me was influential in my decision to leave the school.

L. Opportunities for leadership at the school were influential in my decision to leave the school.

$M$. Teacher involvement in decision making at the school was influential in my decision to leave the school.

$N$. A mismatch between my expectations regarding the school and/or my role and the reality when I arrived was influential in my decision to leave the school.

O. Opportunities for professional advancement elsewhere were influential in my decision to leave the school.

$P$. Personal circumstances were influential in my decision to leave the school.
Chi-Square

df

Asymp. Sig.

5.274

3

.153

3.043

3

.385

.415

3

10.218

3

.017

4.263

3

1.387

3

1.915

3

.590

1.271

3

5.008

3

.171

2.879

3

.411

1.678

3

.642

7.068

3

.070

5.091

3

5.506

3

4.422

3

.219

4.920

3 
Q. Living conditions in the host country were influential in my decision to leave the school.

R. The quality of my personal life while at the school was influential in my decision to leave the school.

a Kruskal Wallis Test

b Grouping Variable: Highest degree you had earned in the year in which you left? 
Teacher Turnover in International Schools

Appendix E: Participant Responses to Prompt Questions 
Question 18: "Please feel free to add explanatory comments for any of the items in the above questions."

\begin{tabular}{|c|c|}
\hline Respondent Number and written response & $\begin{array}{l}\text { Causal } \\
\text { Factor } \\
\text { Categories } \\
\end{array}$ \\
\hline $\begin{array}{l}\text { 4. Crime rate in the country was rising dramatically and the pay did not } \\
\text { compensate for the risk. Strong disagreements with the Primary Principal who } \\
\text { was not an expert in my field and wanted things done his way... when failure } \\
\text { came... then, I was the one to blame!!! }\end{array}$ & $\begin{array}{l}\mathrm{HCC}, \\
\text { Comp, AL }\end{array}$ \\
\hline 6. Profiteering leading to careerism and no education emphasis. & *profiteering \\
\hline 7. is dirty and polluted; I grew sick of the grayness of it. & $\mathrm{HCC}$ \\
\hline $\begin{array}{l}\text { 8. This was my first teaching assignment after getting the PGCE, after moving } \\
\text { from industry into education. I wasn't keen on the USA way of running things } \\
\text { and didn't think much of the school admin. }\end{array}$ & $\overline{\mathrm{AL}}$ \\
\hline $\begin{array}{l}\text { 9. I decided to pursue my interest in Health and fitness and carry out a } \\
\text { diploma in Personal training and the course was based in the UK. }\end{array}$ & PA \\
\hline 10. Response deleted - respondent ineligible. & \\
\hline $\begin{array}{l}\text { 12. I work overseas to travel. I have to really like a place to stay and not move } \\
\text { on. I didn't like the culture in ___ it was very class orientated. I didn't like the } \\
\text { winter. }\end{array}$ & $\mathrm{HCC}$ \\
\hline $\begin{array}{l}\text { 13. A,I,J - Support from director not from principal, communication bad with } \\
\text { admin as they didn't want to listen. All of these workabie though - not enough } \\
\text { to make me leave. K,P, R - Salary not enough to live comfortably with non- } \\
\text { working spouse - moved to a place with better opportunities for spouse. O - } \\
\text { applied only for higher or better positions in other schools - i.e. would not have } \\
\text { moved this year if I hadn't found something better or higher. }\end{array}$ & $\begin{array}{l}\text { AL, Comp, } \\
\text { PA }\end{array}$ \\
\hline 14. Failure to consider employment for spouse a big negative. & $\mathrm{PF}$ \\
\hline $\begin{array}{l}\text { 16. The fact that the school was privately owned and the owner had direct } \\
\text { control over everything financial in the school, including taking money out of } \\
\text { wages for receiving a personal fax, had a huge impact on my decision and } \\
\text { several of my colleagues. There was no trust of teachers or administrators to } \\
\text { do our job and that if we needed resources it was for the students, not because } \\
\text { we were wasteful. }\end{array}$ & $\overline{A L}$ \\
\hline $\begin{array}{l}\text { 17. I had to leave for family health reasons but also because I knew there was } \\
\text { no possibility of professional advancement. }\end{array}$ & PF, PA \\
\hline $\begin{array}{l}\text { 21. The impression from talking to the, now ex, head and the school's } \\
\text { information on their website was very different to what i was met with. Very } \\
\text { unorganized layout and under resourced. }\end{array}$ & PF, WC \\
\hline $\begin{array}{l}\text { 22. Good school, nice country but expensive - especially maintaining a base in } \\
\text { Aus. }\end{array}$ & Comp \\
\hline $\begin{array}{l}\text { 23. A new Principal had joined the school as I joined. The school was a for- } \\
\text { profit, private school. The new Principal wanted to be seen favourably by the } \\
\text { Board of Directors and owners. We spoke with the Principal about the need for } \\
\text { a discipline policy at the school as the behaviour of the students was appalling. } \\
\text { We asked many times but she was reluctant to implement such a policy or } \\
\text { even guidelines. Working at the school was very stressful, especially as it was } \\
\text { a school with children and teachers and we were employed to } \\
\text { teach English with little support from above. I was very ill during the winter } \\
\text { months and the school was overheated, resulting in a poor working / learning } \\
\text { environment. Also, the (ccurrency) crashed twice in } 10 \text { months and I was }\end{array}$ & $\begin{array}{l}\text { SD. WC, } \\
\text { Comp, HCC }\end{array}$ \\
\hline
\end{tabular}


concerned about the financial situation of not only the school, but at large. Finally, I arrived in ___ a year after the huge quake which killed 40,000 people and I experienced two other big quakes in just 10 month's time and they were extremely frightening. I thought it was best to leave and work at a school which met my expectations of what a school should be, how it should be run and how happy I should be professionally. I loved living in ___ but hated teaching those spoilt children who knew that they could do whatever they wanted to do and get away with it.

24. I loved (country name). My wife loved is expensive. We Comp were unable to live on the salary they paid us, as a result we had to use our retirement to get by year to year. We now work in where we are able to bank one entire salary.

26. Living in a country can be trying after a number of years. It was HCC, PF time to move on. 27. Great job - bad employer. $\mathrm{AL}$ 28. Poor and bullying management, excessive workload leading to poor health $A L, W C$ and quality of life. Recruited to the school to take on leadership position but quickly sidelined.

29. A: lack of support reached a point where the newly appointed Head was getting rid of staff not appointed by him and who did not have recent $\mathrm{AL}, \mathrm{AS}, \mathrm{PF}$ teaching experience. B: I arrive in the school mid-year in January and received no induction, not even a buddy to help show me the ropes. D: Student standard of behaviour was slipping as the Head believed the students were outstanding as he had come from a comprehensive school in the Hence standards slipped from what you would expect at a truly international school. F: At my interview I was told a completely new science block was under construction with interactive whiteboards in the majority of rooms - the reality is that construction never even started the entire time I was at the school. H: The school day was being increased so my timetable went from teaching 9 different classes to teaching 13 different classes with a larger range of the three sciences with no extra planning time. N: Quite a number of things I was told at interview turned out to be lies - new science building never became a reality, outstanding accommodation was a crumbling block of flats with construction going on all around them - sometimes until 3am. The interesting thing is I really enjoyed my experience and would have easily stayed for a few more years if it hadn't been for the lies and constant changes being made. The school was reputed to have been one of the best in

32. Colleagues and my own role changed all the time leaving a poor

AL relationship between staff and management (mutual mistrust).

34. Lack of feeling appreciated. After having 5 days off because of illness in first year at the school, I received a letter from the Principal that went on my file, stating that my attendance was a concern to her as it had burdened my colleagues and put my pupils at an unfair advantage. This was shocking to me, but apparently quite typical. Being absent from school was looked on very badly, by colleagues as well as by the administration. 36. I was hired by an outgoing director whom I liked very much, but his PF replacement was not my 'cup of tea'.

38. The main reason I left the school was that the administration had turned over since I was hired. The new administration was a married couple and they were awful. There was no where to go with concerns or complaints. 40. I was the school director and the proprietor took the decision to close the school because we were not making sufficient profit. We were "breaking even". 42. Even though I had 27 years experience and I am an IB HL Chemistry teacher, the salaries in ___ are low. Combine that with very high cost of living and the situation was not tenable. I was going to have to bring large amounts

$\mathrm{AL}$ $\mathrm{AL}$ *profit incentive Comp, PF 
of savings from my home country if was to stay there. Something your survey did not touch upon. Teachers leave a school because they want the next adventure! That's why we are international teachers and not national teachers.

43. The owner was uncaring about the school and a nasty person who had "conflict sycophantic, mean-spirited people working for him. They cared little about the with admin people working there; solely about the power they could exercise. The socalled advisory committee interfered in everything, mostly outside of their scope (even the head of the PTA said so at a public meeting) so much so that the staff actually called a meeting with them--no luck. The attitude toward the locals was neo-colonial. There was just no good morale at that school.

44. For profit schools don't make much progress.

*profit 45. The above are all push factors. In my case, pull factors played a significant PF part, as work with overseas hire status was available elsewhere.

48. At the time, there was a tax benefit for Americans living in Germany for PF two years that strongly influenced my decision to leave. Unfortunately, the enforcement of that law changed after I had already signed on to go somewhere else, so it did not benefit me in the way I had hoped it would. 49. I needed to return to Europe or my children would have to pay overseas fees at university.

50. Having attended the London Job Fair, I expected certain standards of a sanctioned school. Lack of resources, a/c, heating, stationery, high cost of living, additional duties (MYP science mentor, average of 20\%/prep time taken for coverage for absentee teachers) were all unwelcome surprises, explained as only "You didn't ask". Never occurred to me to ask about such issues as heated and air-conditioned classes, overcrowded classroom, sufficient paper supply, or quotas on photocopying, or absence of work books. Consequently, most international teachers leave ___ school before, or as soon as, their contract is over if they have to fulfill the contract to get their fight paid out of

incentive PF 56. There's no team work amongst teachers. There's discrimination (being the WC only Asian) since the pop at school (teachers and parents) is composed predominantly of one race.

59. As "local foreign hires," significant benefits were not available to me and others: housing, airfare and relocation allowance. PD funds, while calculated per teacher, were put into a general fund- resulting in only some teachers' PD requests being granted. The school was very much run as a business, with all tuition/fees sent outside the country and only some allowed to trickle back.

62. I had NEVER been treated and housed so poorly as when I lived in 64. I have left four international schools at the end of my first contract. In three PF, AL cases it was because I had been lied to when I was hired concerning the total package or (in the case of this school) how my package related to others. In this case in year 1 as head of dept I was paid less than all others in my dept in year two this worsened.

66. There was a new principal my second year. He wanted to bring his friends into the school. He told us we had to make a decision to stay or go in January, but he wouldn't assure us of a new contract until April.

68 . I arrived in __ in 2003, only 24 days later the compound where I was living was bombed by Al Qaeda. As I was injured and the school itself was structurally unsafe I returned to the UK for a couple of months. I returned in the August of 2003 but during the following year the amount of terrorist attacks increased and ultimately hindered my feelings of personal safety. The school itself was fantastic, the management strong and the pupils wonderful.

69. Fixed term contract of two years. Requirement to leave the country or start HCC paying tax and pay back tax for the previous two years was the major 
constraint for all of us. See below.

70. Basically, I left due to the way I was treated. A good

$\mathrm{AL}$ administrator/politician (Leader) will be able to satisfy the need to compromise for both sides. Unfortunately most of the time it is too easy to not compromise when the person is in the position of power. The lack of appreciation for me as a teacher was astounding.

71. We had three administrators when I began. They fought amongst

$\mathrm{AL}$ themselves and undermined each other. They refused to let any program decisions be made by the others. Two of the administrators were parents and founders of the school who had no administration background. They were constantly sabotaging each other and had little time for concerns that the staff actual cared about.

74. Please note, I was a Peace Corps Volunteer at the time from 6/19996/2001 where I taught High School students in _.. The contract lasts for two years. I could have extended my contract for one more year, but I chose to return to the US to pursue a Master's degree. I have since completed my second Master's degree in TESOL.

75. The Principal always praised the teachers at the beginning of the day and AL by the end of the day you felt run down to the ground. No one knew where he/she stood. Planners were always criticized. Few positive remarks were made. As a teacher I was rubriced. Students notebooks were rubriced by admin. and strict rules were there for the children and teachers to follow and enforce. No or little consideration of differences in learning styles was taken into account.

80. Response deleted - respondent ineligible

83. My elementary school was only starting its second year, however, it was *ambig attached to a middle \& high school which had been around for fifty years.

88. A range of equally valid reasons as I remember, a sucky Head of Board who had unreasonable expectations of how I should teach her child, a (then) pretty weak Director, whom I know has improved greatly and ... matters of the heart. When a super new job was advertised, it was too tough to resist... I loved living there.

89. I loved the students but I hated the (ethnicity removed) administration. There was major false advertising when hiring staff. I loved the lifestyle of being overseas but I did not feel that I was using my teaching skills to the best of my ability.

91. School did not provide adequate living housing allowance. Only a 1 bedroom apt in a very grim section of town was possible. We felt isolated from the expatriate community and the surrounding neighborhood was unsafe for a 1 year old child to explore.

92. At the International School of __ I was at an exemplary school just at AL, "conflict with admin. the wrong time. is a great place for families and I was a single young woman in a very small and limited town. I could only stand to stay for two years.

93. Management was totally autocratic and there was a definite lack of communication between management and teaching staff.

94. I left during the first year as I got very sick, and ended up in hospital. The AL, PA school offered little support. It turned out to be a tumor so it was a good thing that I came home.

95. Thanks for your interest in International School staffing! I was serving as a whole school HOF in a large International (Comprehensive Prep - Year 12 British curriculum) School. I left the school in disgust as the Head had messed up (for want of a better description) the recruitment process for a Head of Primary (Specialist Subject Area) Department Leader. Instead I was informed the recruitment had gone well and they had enticed another very well qualified 
person to the school (as this person would apparently not come out to without the full HOF title) with the exact same title and job description as my current role involved. Needless to say I spoke to the Head of School about this serious matter, but his response was that he basically owning up to a recruitment bungle and misunderstanding of the job and person they actually needed. However, earlier recruitment discussions I was involved in, as HOF of the whole school Specialist Department, with the Head of Primary School (whose additional role was as my direct Line Manager) and also with the Head of School led me to believe the Senior Management Team were very clear on the type of role they would offer to a potential candidate. This debacle happened in my first International School HOF role, and the incoming Head of Secondary School commented to me that he "had never seen anything like it in another school'. The issue for me now is that I have to keep explaining to new International School employers why l left the job earlier than necessary - it just keeps on coming up as an issue. It is still the shortest serving post I have had. The other thing is that it doesn't make me look all that good, when I was tasked with a difficult assignment to 'raise the profile' of my faculty area within the school community - an assignment which I believe I was very successful at doing in the one and a half years I was working at the school. I left upset and vowing never to take a package at a school where I didn't know the full details of school funding and support, and also that I would only ever work in an International School governed by a Board of Governors or Trust in a not for profit manner. The school at that time was run by a multi-national and high profile company listed on the stock exchange. ____ itself, was fantastic and remains one of my favourite places.

96. The school was a typical for-profit business run by greedy owners (not uncommon circumstances for many overseas schools) but it was well resourced, we were well paid and it tried to be academically oriented. However, _ is not the apex of academic rigour and excellence in was clear that the school was headed downhill and it was time to bail out.

97. Very little staff empowerment in decision making. Also, changing currency $A L, H C C$ made it more expensive for some people to stay. Not taken into account by school. No one body to enable staff to express concerns or issues.

99. $P=$ My partner wished to change careers and return to Canada for school. $Q=$ The city we lived in and the neighborhood where the school and our home was located was very polluted from nearby industry. After two years I was concerned about my health.

102. The culture of for as an expatriate. is beautiful yet is not conducive to what I was looking $\mathrm{HCC}$ 103. Cost of Living was far too high to ensure a quality of life for a family of 4 106. I felt that the principal and the board of governors did not value their best $\mathrm{AL}$ staff and did very little to try to keep them.

107. Senior Management Team (SMT) over the time I was there had no say *private over school direction - all decided by the owner who had limited experience of ownership educational matters. Consequently large SMT staff turnover for all sorts of reasons.

108. QA: Support from the Principal and his Senior Management team was excellent. The problem was very limited support and understanding from the Business leaders/investors of the school. QJ. I have interpreted 'senior management' to mean the Principal and Head of Secondary.

PA, HCC incentive, AS . It

113. My decision to leave was based on my age and my desire to have another international experience. It was also based on becoming more knowledgeable on the politics around the running of the school. In essence it comes down to school values. The housing situation left a lot to be desired. And I feel I have had much more opportunity for advancement and 
professional development in my current school.

114. I did not leave because I was dissatisfied with the school. I left because I PF became engaged and my fiancée was moving to another country.

117. Location of school was changing to an insecure environment (Mining HCC town).

121. Soon after I arrived in ___ I met my husband who is not a teacher. In my second year, I got pregnant and left in the middle of my second year to go on maternity leave. Since my husband got posted back in Germany (he is German) I stayed there for 18 months. Otherwise, we would have been quite happy to stay in and me at the school

123. I was very happy at the school I was at and in __. I just needed a PF change of scene after 4 years and new protessional challenges.

$125 . \quad$ had just experienced three major earthquakes in the previous six HCC months.
129. Students and school facilities great! very polluted so health a
$\mathrm{HCC}, \overline{A L}$ concern. as a managing body extremely unpopular with all staff!

130. You sign for one job, get a totally different one when you arrive, discover the resources are nonexistent, the buildings moldy and collapsing, the kids out of control and the admin barking mad.

142. Response deleted - respondent ineligible.

148. The main reason for leaving was that we could not maintain our mortgage at home on the salary package I was on, especially that the salary did not rise with hyper-inflation in ___. In the last year, we basically ran at a loss and found ourselves in debt, trying to make ends meet.

151. The main reasons I left were because the school blatantly lied to me during the recruitment procedure re: package, what I would be teaching. This was not just me but had been a school policy of the school during that period due to the horrendous financial mess the school was in. I also could not stomach working for the Head of Secondary who had interviewed me as he knew all about this policy but did nothing to fight it. The principal who hired me had already in effect been sacked but saw out the year so I never actually met him to tell how I felt about him personally.

152. School Director was not an educator but a businessman who accepted ALL students because numbers were low but tuition was high! Director lacked people skills and showed up late to school and left early if he showed up at all. In the face of conflict, he would yell and stamp his feet like a spoiled child, that's if he showed up at school. We were paid less than state school teachers and I suspect that those who remained have no choice because they lack (qualification) and can't go to state schools or their personal circumstances forces them to remain in

153. Basically, I felt a bit bored of the place I was at. I learned my school PF system and I knew what to expect for next and next year... I wanted to learn a new system. In addition, I wanted to learn about a new culture and a new country was a big (if not the biggest) reason for leaving. 159. The reasons for leaving were personal really, although we had an
amazing time teaching in ___ and love the ___ friends we made de concern for the safety of my ethnically girlfriend on the streets of was a factor in our decision to leave. We had come across a number of incidents surrounding racial abuse and violence, which started to cause us concern. The government has become increasingly hostile to granting any foreigners work permits and the corruption and bribery became tiresome, especially as the school struggled to deal with it.

161. Loved teaching, had good colleagues and a great social life. However, ${ }^{*}$ profit incentive WC, SD, AL Comp, HCC $\mathrm{PF}, \mathrm{AL}$ PF WC, SD, AL 
career when back in the UK.

164. My son, who was studying in The States was inflicted with, at the time, an unidentifiable illness. Since we did not know how things would turn out, we had to leave and be with him.

166. Unethical director only interested in advancing their $\mathrm{CV}$. $\mathrm{AL}$

168. I also left a school in after initial 2-year contract, 1993-1995. I left that job because of poor pay and therefore unsatisfactory living conditions. In both cases, it was personal factors and low salary, not really the school situation itself, that prompted me to leave after the initial contract.

174. We had decided to see the world by teaching. After two years in one PF place, we had seen most of the important sites around our teaching assignment, so it was time to move on.

178. Board fired Head who had hired me. New head changed job expectations of new hires. 5 of 6 left at the end of the first year.

179. The school had had no hierarchy, as in it had a head teacher and then Comp, PF the teachers. There were no subject coordinators, deputy head etc...

180. I was the Headmaster and left after five years because of taxation related $\mathrm{HCC}$ issues.

182. As a first international placement, the school was fine. The surrounding HCC conditions in were the reason for leaving, especially as a single teacher. 185. I only marked the criteria which really mattered to me in my decision. My first child was born in Dec 2001. After a maternity leave, the birth of my second child, and period off until the summer of 2004 , I wanted to work at the school again. The job offered then was only part time (40\%) and would not have covered my cost of living as a single mother. Being single before, the income was OK but not great as a teacher. Having children, it would have meant to lower my living standard significantly in order to pay particularly for the children's education. The International school I worked at was in the USA. I left to continue living in being a state employee with an almost incomparable benefit package and great flexibility to determine my workload. As it is known, still has a fairly decent income for teachers. In the end, I do miss the educational values of the international school experience. The difference of the value system of international schools is unique and cannot be reached by any "normal" school.

187. Workload in my second and final year just about precluded a social life. 189. Contracts were not renewed by the Board for anyone who had a contract that was ending.

190. This was a summer term temporary maternity leave contract that then became available for a permanent post: I stayed for a full academic year as a mainscale teacher but, wanting to buy a flat in , have chosen to work in the Far East where, receiving a higher salary, will be able to save towards my goal more rapidly.

191. The position was to teach children younger than I had taught before. At

"conflict

between

board and head

$\mathrm{AL}$ $\mathrm{HCC}$ Comp first I felt that I didn't have the expertise needed. By the time I left two years later I was enjoying the job, but at the time I had to make the decision about signing a further contract I was still unsure.

195. Ever hear of scary school stories? How about the first day of school and having no desks, no textbooks, no papers, no chalk, no cupboards... nothing but a bare room with a chalkboard. And the resources didn't come until January and then they were the wrong ones. We bought our own paper and photocopied odds ' $n$ ' sods workbooks from our home countries, and then got yelled at for using too much photocopy toner. The school was run by the Mafia and only worried about their profit, which was dodgy since it was a front for a

WC
${ }^{*}$ contract
issues

Comp

PF

WC, AL,
"profit
incentive


money-laundering setup. They did everything scary possible, including stealing my passport.

196. Would not say it was the school - it was more time to move on. It was PF only when I had left I really appreciated what I had there and could have stayed longer.

198. No

199. The Primary Head and I had diametrically opposing views on the nature

"conflict of education, child-centeredness, professionalism and honesty (academic and with admin professional).

200. Question 1. Principal + senior management should not be put together.

$\mathrm{AL}$ Principal was a hard working \& positive person in the school. The management was dreadful!

201. Not enough professional development opportunities, political climate in PA, HCC the country.

202. International schools promote themselves effectively, but in reality they AS, AL, have access to children from highly motivated backgrounds and tend to sit back and coast. The level of innovation and lack of promotion of up to date teaching and assessment methods was unbelievable. I spent a lot of my time studying new initiatives in the UK myself. There was no tracking or evidence to prove how well the school was doing apart from dubious observations. I felt that if I stayed too long at the school it would reflect poorly on my record and have a negative effect on my professional development. Integrity with SATS testing was an eye opener as well. Very poor communication between head and staff. My quoted salary was incorrectly inflated and nothing was done about it after I moved to The few promotion possibilities were very poorly paid. I did better with private tutoring to supplement my income The school did generously allow me to use my classroom for this).Lack of any kind of planning inspection in the past made the new Deputy Head's job impossible. Impending inspection preparations revealed that nothing was in place and most staff have left.

207. There was a divide and rule ethos and no support, the schools future was AL unstable and I was teaching in a department which was not suitable for my experience or skill and was told I couldn't change to a different year group/subject.

208. The most influential factor for me in deciding to not continue employment $\mathrm{AL}$ at my last school was the inefficient and ineffective administrative staff. Also, they were very unsupportive of their teaching staff living internationally.

209. The school was part of a private company with little knowledge of Comp international education. They relied heavily on the Director of the school, who was incompetent and had lost the support and respect of the majority of the staff. The school has just undergone a joint accreditation process by various organizations including $\mathrm{CIS}$, and although the primary school passed the IB PYP inspection the school 'failed' to be accredited due to ineffective management and administration.

211. After many years abroad as a family we felt the need to return to an PF English-speaking country.

214. The 13 teachers who were hired the same year I was were all lied to by $\mathrm{AL}, \mathrm{PF}$ the hiring principal (who basically told each of us what we wanted to hear to get our contracts) and then quit one week before the beginning of school. A new director also came on board, leaving her with this mess. This is a school which has been dropped from being an "ISS school" and has been reprimanded by ISS during and after the accreditation process for dishonesty and lack of follow through on agreements.

215. New school head was dictatorial and believed he was only one with the answers. 
217. The head was a liar and unethical man.

$\mathrm{AL}$

219. After 5 years the housing stipend ended ie Pay Cut for same job.

Comp

222. Administrative bullying and intimidating of staff, therefore the level of

$\mathrm{AL}$ support was lacking.

223. Refusal of the administration to offer contracts (with salary and other

AL conditions) before April. Significant changes in contract conditions (ie removal of tuition benefits) made late in the year.

225. Response deleted - respondent ineligible.

229. The cost of living in __ was not reflected in the salary or benefits

HCC, Comp package offered by the school.

230. Contract signed was not the assignment I finally was given.

WC

234. 25 yrs over seas, difficult locations but the schools were honest, this one was not. Very disappointed with the school. The building we lived in caught fire they said they would move us as no alarm system, they didn't. Management lack experience and spend all their time studying for masters. No systems in place. I never worked a school like this...not ever! Sad as was ok.

235. Basically, the school was a horrible surprise. Despite being an IBO World School with all three IBO programmes, the IBO philosophy seemed only to apply to advertising. In reality, there were such severe classroom management issues that we were told to teach in a very teacher-directed, worksheet oriented manner so that we would have a small chance of maintaining order.

236. Felt like a prisoner as had to live behind bars at home. School had armed guards. Teachers not allowed to leave school during work day without a written note from Principal!! Parents and Accountant ruled the school. Director a "Yes Man".

238. Grown up children in UK now producing my grandchildren - too far away to keep visiting.

239. I felt that the Head of the school wanted only British teachers, and, as she was not there when I was initially hired, it was evident that she couldn't wait to get me out. She refused to allow me to get certification in England so that I could get a job in another school in the country.

240. My wife (also teaching at the school) was committed to 2 years away $\mathrm{AL}$ from pets/family in Canada. She was ready to come home after the two years. We remained away from home in the summer after the first year and returning home annually may have helped us to stay longer (although we did have many visitors from home and that helped a lot). Also, we were on leave from our Canadian school board and they refused to extend our leave and we were not yet willing to sever ties as jobs in BC were tight at the time. I likely would have stayed in the Int'I school system, but my wife is more cautious;)

244. Years of difficulties have taken their toll and many staff are tired of trying AL so hard with no reward or just criticism and ridicule.

247. I left for personal / professional reasons but have now returned to same school with promotion.

248. The administration had no experience in international schools. They did

HCC not value teacher's inputs and suggestions and were constantly changing schedules and policies. Teachers and students often did not have accurate information about timings, events or rules. Teachers were expected to do an unrealistic amount of paperwork and attend several hours of meetings a week. Duties and extra curricular responsibilities were not divided evenly among teachers. ___ teachers were afraid to speak out for fear of losing their jobs and asked Western teachers to speak for them at meetings. I found out that a man with less experience and fewer qualifications was making almost double my salary. This combination of problems made me feel as though I had no choice but to leave, to preserve my own dignity and sanity. 
251. My reasons for leaving were a combination of school frustrations and the quality of life in . The school remuneration package was very good and there were many opportunities for professional development, but pressure of work was enormous in the Counseling area. Senior management did not seem to have a true picture of the time required to support students in their learning, emotional issues and in university/college applications. Thus most week-ends were taken up with work which could not be done during the day. I suppose I did not feel valued. Management spoke appreciatively, but did not provide the additional support to enable us to work efficiently. I also felt that some middle and senior management were more concerned with building their CVs than with the overall direction of the school, thus internal politics also made life uncomfortable and, at times, uncertain. In addition I found to be far too 'concrete', lacking in green spaces. There were many wonderful opportunities for travel in the region, but these did not compensate for life in a large, noisy, crowded city. Having worked in seven international schools over the past 25 years, this particular contract is the only one where I did not feel settled. I loved everywhere else (including my current job and location), both the schools and the environments, which were very diverse. I suspect that if I had thoroughly enjoyed working at the school (as I did elsewhere) then that would have compensated for life in ___ and I would have stayed longer. It might be worth noting that this was my first large school, so perhaps the sense of community that comes with a much smaller school environment was lacking.

252. Question A is hard to answer. Professional jealousy and a hate campaign directed by the senior administrators at me drew my job to a conclusion. I was blackmailed unjustly into leaving. It seems common that international schools can operate outside the laws of the host country.

\section{There were NO textbooks for my history classes. They were not} expecting a 1st-year+ teacher; there was no support. Accommodations were miniscule \& below standards I am used to living in. They asked me to teach drama, which ended up being ${ }^{*} I B^{*}$ Drama. NOWHERE on my C.V. is there ANY mention of drama. The principal told me his son "loved" my class \& then 2 weeks later he asked me to go \& had somebody (another teacher's fiancée) on the spot $\&$ in my place teaching.

261. A, The principal, from _ made a great number of promises about remuneration, additional management/responsibilities and most importantly Professional Development which upon arrival into the country were directly contradicted. Several staff left the school before their contracts were due to end, I stayed for the sake of the children and a sense of responsibility to the school's community. J, As a member of the Senior Management, in my second year of the two-year contract, I worked tirelessly to bridge the gap between disgruntled faculty and the principal. However his attitude was to recruit more staff and penalize existing staff by threatening to take legal action, with-hold final salaries and 'black-list' staff on the international circuit. His autocratic, 'culture of fear' affected many junior staff and in the time since I have been there all of the 26 foreign staff bar one have left, most after their first contract. $\mathrm{K}$, Our salary was pegged to the USD and at a time when our salaries were plummeting the management of the school decided to ignore specific requests from a united staff to set a capped calculation rate. The promises were made before the Christmas break, assuring a high salary which was then removed without explanation upon return to the school after the holidays. Remuneration did not increase until AFTER completion of the first contract, a period of two years. $M$, Teaching staff, including members of the management team I was to discover in my second year, were routinely ignored, threatened and belittled when decisions affecting the whole staff were being made, including housing, salaries and professional development. N, As mentioned above, a great number of promises were made prior to arrival into the country and these were
$\mathrm{HCC}, \overline{\mathrm{WC}}$, AL

${ }^{*}$ conflict with admin WC, AL, HCC

${ }^{*}$ conflict with admin, AL, Comp, 
removed once I and a number of other staff arrived on-site.

263. Low salary - no yearly increments. Insufficient rewards for extra

Comp responsibility - virtually no allowance for shipping and no settling in allowance poor health insurance cover.

265. The school itself and the induction upon arriving were satisfactory,

HCC however I found the language barrier, and weather difficult. Also, I found that most other international schools wanted teachers with experience in the PYP which my school did not follow.

273. The school was a primary and early years school with secondary tacked *ambig on at the end. Being a secondary teacher it is very difficult to function.

275. I found that the Headmaster, _ was sub par... as far as a leader/headmaster was concerned. He had nothing to do with the school and/or his staff. In general, he created a negative working environment that I was not impressed with.

276. The head teacher frequently blatantly lied to me and other staff about many issues regarding resources, placements, curriculum. We were unable to run a proper program due to lack of resources (when we asked we would be told that they were on the way from US but they never arrived). Decisions were made about the placement of students that were based on financial reasons rather than needs of the child. The deputy head was only concerned with the secondary section of the school and its needs always came before those of the primary section and he refused to deal with primary teachers concerns saying that it wasn't his job. Some teachers were offered different contracts and pay scale to others when they threatened to leave in order to reduce the turnover of staff.

277. For me, the biggest factor in creating an enjoyable and fulfilling environment to work in is the school administration and/or board, and how they relate to the staff.

278. I was teaching second grade. This was a job I was able to do and I did it well. But my forte and qualifications were all in Special Ed and ESL. I was told at interview that a position would become free at some point. These positions were held down by local hire who did not have my experience or qualifications. There is no evidence to support the idea that a local hire would be any less transient than overseas hire. Therefore this promise of a position later on came down to finances. Obviously local hire were cheaper. The school hoped to satisfy my needs by putting me in charge of a focus group in ESL. The work was interesting, free of charge and resulted in a valuable document. It did me no favors with a department that saw me as an outsider!

279. We (my partner and I) left the school because after 4 years we felt that we had reached our personal goals for advancement and job satisfaction and were ready for a new challenge in a new working environment.

283. We left when we decided it was time to start a family and we wanted to

AL $A L, W C$, *profit incentive, contract issues AL be closer to our parents.
be left when we de

${ }^{*}$ contract issues 
Question 19a: "What were the top three reasons that prompted you to leave the school"?

\begin{tabular}{|c|c|}
\hline Respondent Number and written response & $\begin{array}{l}\text { Causal Factor } \\
\text { Categories } \\
\end{array}$ \\
\hline 1. A J & $\mathrm{AL}$ \\
\hline 2. Mismanagement & $\overline{A L}$ \\
\hline 3. Wanderlust & PF \\
\hline 4. School management & $\mathrm{AL}$ \\
\hline 5. Travel lust & $\mathrm{PF}$ \\
\hline 6. Profiteering & ${ }^{\star}$ Profiteering \\
\hline 7. Pollution & $\mathrm{HCC}$ \\
\hline 8. The principal & $\begin{array}{l}{ }^{\star} \text { Conflict with } \\
\text { administrator }\end{array}$ \\
\hline 9. Gain a new qualification & $\mathrm{PA}$ \\
\hline \multicolumn{2}{|l|}{ 10. Response deleted - participant ineligible } \\
\hline 11. Instability of position (delay in knowing whether there was a vacancy) & WC \\
\hline 12. Culture and climate of host country & $\mathrm{HCC}$ \\
\hline 13. Lack of money to support family & Comp \\
\hline 14. Dollar pound exchange rate/pay & Comp \\
\hline 15. Administration & $\overline{A L}$ \\
\hline 16. Frustration with it being privately owned & $\begin{array}{l}{ }^{*} \text { Private } \\
\text { ownership }\end{array}$ \\
\hline 17. Family health reasons & $\mathrm{PF}$ \\
\hline 18. New leadership with little focus on kids & $\mathrm{AL}$ \\
\hline 19. Disregard of student needs at the high school level & $\mathrm{AL}$ \\
\hline 20. Job & "Ambiguous \\
\hline 21. Distance from Family & PF \\
\hline 22. A bit hard o get home at times & $\mathrm{PF}$ \\
\hline 23. Unhappiness with the way the school was being run & $\mathrm{AL}$ \\
\hline 24. Salary & Comp \\
\hline 25. Lack of Support from administration & $\mathrm{AL}$ \\
\hline 26. Distance from Canada & $\mathrm{PF}$ \\
\hline 27. Merit pay was subjective & $\mathrm{AL}$ \\
\hline 28. Poor and bullying management, & $\mathrm{AL}$ \\
\hline 29. Better management & $\overline{A L}$ \\
\hline 30. No professional development & WC \\
\hline 31. Family needs & $\mathrm{PF}$ \\
\hline 32. Prospect of promotion & $\overline{\mathrm{PA}}$ \\
\hline 33. The level of support from Admin & $\mathrm{AL}$ \\
\hline \multicolumn{2}{|l|}{34.} \\
\hline 35. Management decisions & $\mathrm{AL}$ \\
\hline 36. Senior management were not my style & $\overline{A L}$ \\
\hline 37. I wanted to teach in Europe Again & $\mathrm{PF}$ \\
\hline 38. Administration & $\overline{A L}$ \\
\hline 39. Assigned 5 different preps & WC \\
\hline 40. School closed & $\begin{array}{l}{ }^{*} \text { School } \\
\text { closure }\end{array}$ \\
\hline 41. Poor management & $\mathrm{AL}$ \\
\hline
\end{tabular}




\begin{tabular}{|c|c|}
\hline 42. Inadequate salary & Comp \\
\hline 43. Interference of advisory board & *Board issues \\
\hline 44. Travel & $\mathrm{PF}$ \\
\hline 45. Local hire status & $\begin{array}{l}{ }^{*} \text { Contractual } \\
\text { issues }\end{array}$ \\
\hline 46. Advancement & $\mathrm{PA}$ \\
\hline 47. Management & $\overline{\mathrm{AL}}$ \\
\hline 48. Tax situation & $\mathrm{HCC}$ \\
\hline \multicolumn{2}{|l|}{49.} \\
\hline $\begin{array}{l}\text { 50. School misrepresented itself. Not international with } 90 \% \text { student } \\
\text { population being }\end{array}$ & $\begin{array}{l}{ }^{*} \text { Misrepresent- } \\
\text { ation during } \\
\text { recruitment }\end{array}$ \\
\hline 51. Taxes in general & $\mathrm{HCC}$ \\
\hline 52. Career advancement & $\overline{\mathrm{PA}}$ \\
\hline 53. Bad management & $\mathrm{AL}$ \\
\hline \multicolumn{2}{|l|}{54.} \\
\hline 55. Live in new place & $\mathrm{PF}$ \\
\hline 56. Still new to international setting so I wanted to try another placement & $\mathrm{PF}$ \\
\hline 57. Personal - related to host city & $\mathrm{HCC}$ \\
\hline 58. Salary & Comp \\
\hline 59. Low salary & Comp \\
\hline 60. Salary after year two is taxed in both host and home countries & $\mathrm{HCC}$ \\
\hline 61. Retirement age 62 and they take away one's housing & $\begin{array}{l}\text { *Contractual } \\
\text { issue }\end{array}$ \\
\hline 62. Admin telling us that we were all worthless & $\mathrm{AL}$ \\
\hline 63. The school went bankrupt due to poor administrative leadership & $\begin{array}{l}\text { *School } \\
\text { closure/ AL }\end{array}$ \\
\hline 64. Head lied about package & $\begin{array}{l}{ }^{*} \text { Misrepresent- } \\
\text { ation during } \\
\text { recruitment }\end{array}$ \\
\hline 65. Lack of challenge & $\overline{P A}$ \\
\hline 66. New administrator was a fool & $\mathrm{AL}$ \\
\hline 67. No possibility of work for spouse & $\mathrm{PF}$ \\
\hline 68. Bombing & $\mathrm{HCC}$ \\
\hline 69. Fixed term contract. & $\begin{array}{l}{ }^{*} \text { Contractual } \\
\text { issues }\end{array}$ \\
\hline 70. Lack of support, way I was treated & $\mathrm{AL}$ \\
\hline 71. Dishonesty in hiring practices & $\begin{array}{l}\text { "Misrepresent- } \\
\text { ation during } \\
\text { recruitment }\end{array}$ \\
\hline $\begin{array}{l}\text { 72. Needed to complete service requirement for U.S. teacher retirement } \\
\text { system }\end{array}$ & PA \\
\hline 73. The quality of my personal life & PF \\
\hline 74. End of contract & $\begin{array}{l}{ }^{*} \text { Contractual } \\
\text { issues }\end{array}$ \\
\hline 75. Lack of support from the Principal & $\mathrm{AL}$ \\
\hline 76. Lack of academic ambition & AS \\
\hline 77. Administration not qualified & $\mathrm{AL}$ \\
\hline 78. The culture in & $\mathrm{HCC}$ \\
\hline 79. Poor communication & $\mathrm{AL}$ \\
\hline
\end{tabular}




\begin{tabular}{|c|c|}
\hline 80. Response deleted - participant ineligible & \\
\hline 81. Poor professional development options & WC \\
\hline 82. Wanted to go back to school and study MA & $\overline{\mathrm{PA}}$ \\
\hline $\begin{array}{l}\text { 83. It was expected that teaching elementary school was not enough. } \\
\text { Teachers had to supervise high school students also. }\end{array}$ & WC \\
\hline 84. Need to provide a retirement & Comp \\
\hline 85. Personal & PF \\
\hline 86. Looking for professional advancement & PA \\
\hline 87. Exhaustion & PF \\
\hline 88. New Job & $\mathrm{PA}$ \\
\hline 89. Administration & $\mathrm{AL}$ \\
\hline 90. A & $\mathrm{AL}$ \\
\hline 91. Financially inadequate & Comp \\
\hline 92. No opportunities for cultural enrichment & $\mathrm{HCC}$ \\
\hline 93. Lack of opportunity for advancement & PA \\
\hline 94. No support from Principal & $\mathrm{AL}$ \\
\hline $\begin{array}{l}\text { 95. Poor decision making on recruitment that directly affected current serving } \\
\text { staff roles - both job and person specifications }\end{array}$ & $\begin{array}{l}\text { "Misrepresent- } \\
\text { ation during } \\
\text { recruitment }\end{array}$ \\
\hline 96. Conflicts between the owner(s) and the administrators & $\begin{array}{l}\text { *Private } \\
\text { ownership }\end{array}$ \\
\hline 97. Lack of promotional opportunities & $\overline{\mathrm{PA}}$ \\
\hline 98. Host Country Living Conditions & $\mathrm{HCC}$ \\
\hline 99. Worry about long term health problems from pollution in the community. & $\mathrm{HCC}$ \\
\hline 100. Role of the Director and Board & ${ }^{\star}$ Board issues \\
\hline 101. Career advancement & $\mathrm{PA}$ \\
\hline 102. More adventure elsewhere & $\mathrm{PF}$ \\
\hline 103. Finances & Comp \\
\hline 104. Lack of professionalism of head & $\mathrm{AL}$ \\
\hline 105. Salary package & Comp \\
\hline 106. Salary insufficient & Comp \\
\hline 107. Owner of the School & $\begin{array}{l}\text { *Private } \\
\text { ownership }\end{array}$ \\
\hline 108. Pollution levels affect health & $\mathrm{HCC}$ \\
\hline 109. Family lilness in Australia & PF \\
\hline \multicolumn{2}{|l|}{110.} \\
\hline 111. Remuneration insufficient & Comp \\
\hline 112. Personal life & $\mathrm{PF}$ \\
\hline $\begin{array}{l}\text { 113. Desire to have another international experience especially in a non- } \\
\text { proprietary school }\end{array}$ & PF \\
\hline 114. Engaged & $\mathrm{PF}$ \\
\hline 115. Visa problems & $\begin{array}{l}\text { "Visa } \\
\text { problems }\end{array}$ \\
\hline 116. Compensation & Comp \\
\hline \multicolumn{2}{|l|}{117.} \\
\hline 118. Pay & Comp \\
\hline 119. Did not know if my contract would be renewed & $\begin{array}{l}\text { "Contractual } \\
\text { issues }\end{array}$ \\
\hline 120. The lack of support from colleagues & WC \\
\hline
\end{tabular}




\begin{tabular}{|c|c|}
\hline 121. & \\
\hline 122. Pay & Comp \\
\hline 123. Desire to explore elsewhere & $\mathrm{PF}$ \\
\hline 124. Unsupportive Principal & $\mathrm{AL}$ \\
\hline 125. $\mathrm{M}$ & $\overline{\mathrm{AL}}$ \\
\hline \multicolumn{2}{|l|}{126.} \\
\hline 127. $\mathrm{G}$ (from above) & AS \\
\hline 128. Career change & PA \\
\hline 129. ESF & ${ }^{*}$ Ambiguous \\
\hline 130. No discipline policies in place & $\overline{\mathrm{AL}}$ \\
\hline 131. Standard of living in the host country & $\mathrm{HCC}$ \\
\hline 132. Locality of school in city & $\begin{array}{l}\text { "Location of } \\
\text { school }\end{array}$ \\
\hline 133. Lack of Director support & $\mathrm{AL}$ \\
\hline 134. Boredom & $\mathrm{PF}$ \\
\hline 135. Career advancement & $\mathrm{PA}$ \\
\hline 136. Lack of leadership & $\mathrm{AL}$ \\
\hline 137. Student behavior. & SD \\
\hline 138. Economic & ${ }^{*}$ Ambiguous \\
\hline 139. Promotion & PA \\
\hline 140. Quality of Life in Country & $\mathrm{HCC}$ \\
\hline 141. Problems with getting working Visa & $\begin{array}{l}{ }^{*} \text { Visa } \\
\text { problems }\end{array}$ \\
\hline \multicolumn{2}{|l|}{ 142. Response deleted - participant ineligible } \\
\hline 143. Low pay & Comp \\
\hline 144. Quality of personal life & $\mathrm{PF}$ \\
\hline 145. Social life & $\mathrm{PF}$ \\
\hline \multicolumn{2}{|l|}{146.} \\
\hline 147. Financial & Comp \\
\hline 148. Very low salary & Comp \\
\hline 149. Poor salary & Comp \\
\hline 150. My husband was placed in Europe & $\mathrm{PF}$ \\
\hline 151. Lies about package during recruitment procedure & $\begin{array}{l}\text { *Misrepresent- } \\
\text { ation during } \\
\text { recruitment }\end{array}$ \\
\hline 152. Pay & Comp \\
\hline 153. Felt bored & PF \\
\hline 154. Lack of professional advancement & $\mathrm{PA}$ \\
\hline 155. Corruption & "Ambiguous \\
\hline 156. Lack of support from the SLT & $\mathrm{AL}$ \\
\hline 157. (D) & SD \\
\hline 158. Others were moving on also, ready for new environment & $\mathrm{PF}$ \\
\hline 159. Wanting to continue traveling elsewhere. & $\mathrm{PF}$ \\
\hline 160. Personal circumstances & $\mathrm{PF}$ \\
\hline 161. Lack of professional development & WC \\
\hline 162. Director & $\mathrm{AL}$ \\
\hline 163. Support from Elementary Principal & $\mathrm{AL}$ \\
\hline 164. See previous comment. & PF \\
\hline
\end{tabular}




\begin{tabular}{|c|c|}
\hline 165. Compensation package & Comp \\
\hline 166. Poor admin & $\mathrm{AL}$ \\
\hline 167. Personal Reasons & $\mathrm{PF}$ \\
\hline 168. To join partner in another country & $\mathrm{PF}$ \\
\hline 169. School climate & WC \\
\hline 170. 3 years enough in one place and want new experience & $\overline{\mathrm{PF}}$ \\
\hline 171. Personal threats from the Principal & $\overline{\mathrm{AL}}$ \\
\hline 172. Communication between administration and teachers & $\mathrm{AL}$ \\
\hline 173. No support nor training regarding IB teaching & WC \\
\hline 174. Our age & PF \\
\hline 175. Availability of resources & WC \\
\hline 176. Money & Comp \\
\hline 177. Management & $\mathrm{AL}$ \\
\hline 178. Student/parent attitude -everyone gets an $A$ & $\overline{W C}$ \\
\hline 179. Lack of professionalism & WC \\
\hline 180. Taxation & $\mathrm{HCC}$ \\
\hline 181. School owner was unpredictable, micromanaged all school affairs & $\begin{array}{l}\text { *Private } \\
\text { ownership }\end{array}$ \\
\hline 182. Not satisfied with the country & $\mathrm{HCC}$ \\
\hline 183. Poor Air Quality in & $\mathrm{HCC}$ \\
\hline $\begin{array}{l}\text { 184. Promises regarding salary and conditions promised at interview not } \\
\text { fulfilled }\end{array}$ & $\begin{array}{l}{ }^{*} \text { Misrepresent- } \\
\text { ation during } \\
\text { recruitment }\end{array}$ \\
\hline 185. Lower workload than before & WC \\
\hline 186. Seeking employment in same location as spouse & $\mathrm{PF}$ \\
\hline 187. Workload & WC \\
\hline 188. Didn't want to offer me the position I specialize in & $\begin{array}{l}{ }^{*} \text { Conflict with } \\
\text { administrator }\end{array}$ \\
\hline 189. No Contact Renewal & $\begin{array}{l}{ }^{*} \text { Contractual } \\
\text { issues }\end{array}$ \\
\hline 190. Money & Comp \\
\hline $\begin{array}{l}\text { 191. I wanted to return to teaching children with greater learning difficulties } \\
\text { than the international school would admit }\end{array}$ & $\mathrm{PF}$ \\
\hline 192. Uneven workloads & WC \\
\hline 193. Personal & $\mathrm{PF}$ \\
\hline 194. Host country living conditions & $\mathrm{HCC}$ \\
\hline 195. Administration & $\mathrm{AL}$ \\
\hline 196. Technology & *Ambiguous \\
\hline 197. Ready for a change in principal/leadership management & $\mathrm{PF}$ \\
\hline 198. Low Salary & Comp \\
\hline 199. See 18. This was the only reason. & $\begin{array}{l}\text { "Conflict with } \\
\text { administrator }\end{array}$ \\
\hline 200. Managers with no educational background & $\overline{A L}$ \\
\hline 201. Personal & $\mathrm{PF}$ \\
\hline 202. Bored & $\mathrm{PF}$ \\
\hline 203. Management integrity (lack of) & $\mathrm{AL}$ \\
\hline 204. Teachers were unimportant at the school & $\mathrm{AL}$ \\
\hline 205. Low salary & Comp \\
\hline 206. Lack of support and lack of communication with senic & $\mathrm{AL}$ \\
\hline
\end{tabular}




\begin{tabular}{|c|c|}
\hline especially where decision making was concerned & \\
\hline 207. Financial- I was part time & $\mathrm{PF}$ \\
\hline 208. Inadequate administrative staff & WC \\
\hline 209. Incompetence of Director & $\mathrm{AL}$ \\
\hline 210. Financial & Comp \\
\hline 211. My children's needs & $\mathrm{PF}$ \\
\hline 212. New child in the family & $\mathrm{PF}$ \\
\hline 213. Bad administrators & $\overline{\mathrm{AL}}$ \\
\hline 214. Lack of integrity from the top down. & $\overline{A L}$ \\
\hline 215. Management change & $\mathrm{AL}$ \\
\hline 216. Poor Administrative leadership & $\overline{A L}$ \\
\hline 217. Head & $\mathrm{AL}$ \\
\hline 218. Unhappy with Admin & $\overline{\mathrm{AL}}$ \\
\hline 219. Pay cut & Comp \\
\hline 220. Disagreement with Head over educational issues & $\begin{array}{l}{ }^{\star} \text { Conflict with } \\
\text { administrator }\end{array}$ \\
\hline 221. Poor ESL program & AS \\
\hline 222. HOS intimidation and bullying of staff & $\mathrm{AL}$ \\
\hline $\begin{array}{l}\text { 223. Ambiguity over contract renewal i.e. teachers asked to sign contracts } \\
\text { without knowing their salary or benefits }\end{array}$ & $\begin{array}{l}\text { "Contractual } \\
\text { issues }\end{array}$ \\
\hline 224. Lack of adequate facilities for my subject & WC \\
\hline 225. Response deleted - participant ineligible & \\
\hline 226. Lack of communication with Upper School Principal & $\mathrm{AL}$ \\
\hline 227. Low salary & Comp \\
\hline 228. Communication & $\mathrm{AL}$ \\
\hline 229. Salary too low for cost of living & Comp \\
\hline 230. Chances to teach what my original contract said were nil & $\begin{array}{l}\text { "Misrepresent- } \\
\text { ation during } \\
\text { recruitment }\end{array}$ \\
\hline 231. Lack of administrative support & $\mathrm{AL}$ \\
\hline 232. Workload & WC \\
\hline 233. Frustration with management decisions & $\mathrm{AL}$ \\
\hline 234. Zero management ability & $\overline{A L}$ \\
\hline 235. Out-of-control behavior of students & SD \\
\hline 236. Living Conditions & $\mathrm{HCC}$ \\
\hline 237. Private ownership & $\begin{array}{l}\text { "Private } \\
\text { ownership }\end{array}$ \\
\hline 238. Daughter in UK having baby & $\mathrm{PF}$ \\
\hline 239. Not permitted to get that country's certification. & $\begin{array}{l}\text { "Visa } \\
\text { problems }\end{array}$ \\
\hline 240. Homesickness/pets/family at home & $\mathrm{PF}$ \\
\hline 241. Lack of professional advancement & PA \\
\hline 242. Poor salary & Comp \\
\hline 243. Work permit non-removal & $\begin{array}{l}\text { "Visa } \\
\text { problems }\end{array}$ \\
\hline 244. Financial & Comp \\
\hline 245. Personal reasons & $\mathrm{PF}$ \\
\hline 246. Home robbery & $\mathrm{HCC}$ \\
\hline 247. Personal/professional non teaching goals & PF \\
\hline
\end{tabular}




\begin{tabular}{|c|c|}
\hline 248. Unrealistic Administrative Expectations & WC \\
\hline 249. Better package & Comp \\
\hline 250. Lack of direction from management & $\mathrm{AL}$ \\
\hline $\begin{array}{l}\text { 251. Frustration at lack of support for the development of a caring and efficient } \\
\text { counseling department. }\end{array}$ & $\mathrm{AL}$ \\
\hline 252. No choice & $\mathrm{PF}$ \\
\hline 253. Living condition & $\mathrm{HCC}$ \\
\hline 254. Remuneration Package & Comp \\
\hline 255. Lies told by superintendent & $\mathrm{AL}$ \\
\hline 256. They told me to leave & ${ }^{*}$ Fired \\
\hline 257. Time to move on - new challenges, & $\mathrm{PF}$ \\
\hline 258. Lack of support from management & $\overline{A L}$ \\
\hline 259. IBDip was not offered at that stage & AS \\
\hline 260. Fatigue & $\mathrm{PF}$ \\
\hline 261. Manipulative, deceitful management & $\mathrm{AL}$ \\
\hline 262. Pay & Comp \\
\hline 263. Poor package & Comp \\
\hline 264. Personal circumstances & PF \\
\hline 265. Fiancée at home & $\mathrm{PF}$ \\
\hline 266. The revolting head of school & $\mathrm{AL}$ \\
\hline 267. No progression & ${ }^{*}$ Ambiguous \\
\hline 268. Too high a workload & WC \\
\hline 269. My husband was unable to find a permanent job & $\mathrm{PF}$ \\
\hline \multicolumn{2}{|l|}{ 270. Response deleted - participant ineligible } \\
\hline 271. Personal reasons & PF \\
\hline 272. My partner was keen to move on & PF \\
\hline 273. Inept management & $\mathrm{AL}$ \\
\hline 274. Low salary & Comp \\
\hline 275. A poor Headmaster & $\overline{A L}$ \\
\hline 276. Poor communication from administrators & $\mathrm{AL}$ \\
\hline 277. Hypocritical and down right nasty principal & $\mathrm{AL}$ \\
\hline 278. Not the right position & PF \\
\hline 279. Lack of Professional development opportunities & WC \\
\hline 280. Family & PF \\
\hline 281. Administration & $\overline{A L}$ \\
\hline 282. Family illness & $\mathrm{PF}$ \\
\hline 283. Personal family decision & $\mathrm{PF}$ \\
\hline 284. Management & $\overline{A L}$ \\
\hline 285. Wanted to go back to Asia & $\mathrm{PF}$ \\
\hline 286. Unprofessional and inhumane treatment of staff & $\mathrm{AL}$ \\
\hline
\end{tabular}


Question 19 b: "What were the top three reasons that prompted you to leave the school?"

\begin{tabular}{|c|c|}
\hline Respondent Number and written response & $\begin{array}{l}\text { Causal Factor } \\
\text { Categories }\end{array}$ \\
\hline $1 . \quad \mathrm{N}$ & $\mathrm{PF}$ \\
\hline Poor discipline & SD \\
\hline Limited possibilities in the country & $\mathrm{HCC}$ \\
\hline Dangerous country & $\mathrm{HCC}$ \\
\hline Improved promotion prospects & $\mathrm{PA}$ \\
\hline No Education emphasis & AS \\
\hline Sick of & $\mathrm{HCC}$ \\
\hline Lack of support/interest from principal and his deputies & $\mathrm{AL}$ \\
\hline $\begin{array}{l}\text { Location as it was a small town. Great for families but no so good } \\
\text { for single foreigners. }\end{array}$ & $\mathrm{PF}$ \\
\hline \multicolumn{2}{|l|}{10.} \\
\hline Unstable/unsupportive management & $\overline{A L}$ \\
\hline Remuneration package & Comp \\
\hline Lack of opportunities for spouse & PF \\
\hline Health/family life & $\mathrm{PF}$ \\
\hline Lack of confidence in teacher support & $\overline{A L}$ \\
\hline $\begin{array}{l}\text { 16. High work load of being English Lit teacher - marking and reporting } \\
\text { hours not recognized as being significantly larger than other subject } \\
\text { areas. }\end{array}$ & WC \\
\hline No possibility for leadership & $\mathrm{PA}$ \\
\hline Limited opportunities for professional growth & $\overline{\mathrm{PA}}$ \\
\hline Treatment of staff & $\overline{A L}$ \\
\hline Location & $\mathrm{PF}$ \\
\hline Accornmodation & $\mathrm{HCC}$ \\
\hline Little opportunity for advancement & PA \\
\hline $\begin{array}{l}\text { The students at the school were not motivated and teaching was } \\
\text { not enjoyable as a result of their poor behavior }\end{array}$ & $\mathrm{SD}$ \\
\hline Living expenses & $\mathrm{HCC}$ \\
\hline Human Resources treating teachers like a burden & $\mathrm{AL}$ \\
\hline New opportunities & $\mathrm{PA}$ \\
\hline $\begin{array}{l}\text { 27. Decisions were made by the business side, not educationally } \\
\text { sound }\end{array}$ & $\begin{array}{l}\text { *Profit } \\
\text { incentive }\end{array}$ \\
\hline Excessive workload & WC \\
\hline Change in accommodation & $\mathrm{HCC}$ \\
\hline No possibility of management positions & $\mathrm{PA}$ \\
\hline \multicolumn{2}{|l|}{31.} \\
\hline Relationship between management and staff & $\overline{\mathrm{AL}}$ \\
\hline \multicolumn{2}{|l|}{$-2 \mathrm{C}$} \\
\hline \multicolumn{2}{|l|}{34.} \\
\hline HOD decisions & $\overline{A L}$ \\
\hline Salary/package was very low & Comp \\
\hline The LS Admin & $\mathrm{AL}$ \\
\hline Administration & $\overline{A L}$ \\
\hline Required to teach $4 \mathrm{IB}$ courses & WC \\
\hline 40. & \\
\hline
\end{tabular}




\begin{tabular}{|c|c|c|}
\hline 41. & Very low student numbers & $\begin{array}{l}\text { "Low student } \\
\text { numbers }\end{array}$ \\
\hline 42. & Wanting the next adventure & PF \\
\hline \multicolumn{3}{|c|}{$x_{2}$} \\
\hline 44. & Low pay & Comp \\
\hline 45. & Overseas hire offered elsewhere & PA \\
\hline 46. & Family Life & $\overline{\mathrm{PF}}$ \\
\hline 47. & Quality of Staff & $\begin{array}{l}{ }^{*} \text { Quality of } \\
\text { staff }\end{array}$ \\
\hline 48. & Lack of professional development opportunities & $\mathrm{PA}$ \\
\hline \multicolumn{3}{|c|}{ r } \\
\hline 50. & $\begin{array}{l}\text { Admin. was not forthcoming re: physical structure, resources, job } \\
\text { ectations. (see above \#18) }\end{array}$ & $\begin{array}{l}\text { "Misrepre- } \\
\text { sentation }\end{array}$ \\
\hline 51. & Tax on children's tuition & $\mathrm{HCC}$ \\
\hline 52. & Compensation package & Comp \\
\hline 53. & Bad pay & Comp \\
\hline \multicolumn{3}{|l|}{55.} \\
\hline 55. & Compensation package & Comp \\
\hline 56. & Poor professionalism from the administrators & $\mathrm{AL}$ \\
\hline 57. & Lack of involvement from Admin & $\mathrm{AL}$ \\
\hline 58. & Private owner & $\begin{array}{l}\text { *Private } \\
\text { ownership }\end{array}$ \\
\hline 59. & Lack of sufficient benefits & Comp \\
\hline 60. & Weak administration policies with regards to discipline, etc. & $\mathrm{AL}$ \\
\hline 61. & Thai fathers did not understand how to run a school & $\mathrm{AL}$ \\
\hline 62. & Housing was deplorable. & $\mathrm{HCC}$ \\
\hline 63. & Teacher involvement is very poor. & $\mathrm{AL}$ \\
\hline 64. & Head treated other staff badly & $\mathrm{AL}$ \\
\hline 65. & Financial package & Comp \\
\hline 66. & Lack of resources & WC \\
\hline 67. & Salary & Comp \\
\hline 68. & Terrorism & $\mathrm{HCC}$ \\
\hline 69. & Tax and social security payments. & $\mathrm{HCC}$ \\
\hline 70. & School Standards, policies & $\mathrm{AL}$ \\
\hline 71. & Infighting among the administration & $\overline{A L}$ \\
\hline \multicolumn{3}{|c|}{ - } \\
\hline 73. & The poor administration & $\mathrm{AL}$ \\
\hline 74. & Desire to pursue a degree in education & $\overline{\mathrm{PA}}$ \\
\hline 75. & I did not know where I stood & $\mathrm{AL}$ \\
\hline 76. & Lack of professional advancement & $\mathrm{PA}$ \\
\hline 77. & Communication within school & $\overline{A L}$ \\
\hline 78. & Unpleasant management team & $\mathrm{AL}$ \\
\hline 79. & Professional Development Opportunities & $\mathrm{PA}$ \\
\hline 80. & Response deleted - participant ineligible & \\
\hline 81. & Top level of pay scale was MA +8 years & Comp \\
\hline 82. & Ready to move on & $\mathrm{PF}$ \\
\hline & $\begin{array}{l}\text { They did not want to pay me the salary I asked, which was very } \\
\text { sonable. }\end{array}$ & Comp \\
\hline 84. & & \\
\hline
\end{tabular}




\begin{tabular}{|c|c|c|}
\hline 85. & Outside activities & "Ambig \\
\hline 86. & Personal - getting married & PF \\
\hline 87. & Extremely demanding students & SD \\
\hline 88. & Job Dissatisfaction & $\mathrm{PF}$ \\
\hline 89. & Wrong program for me & $\overline{\mathrm{PF}}$ \\
\hline 90. & $\mathrm{~J}$ & $\mathrm{AL}$ \\
\hline 91. & Housing inadequate & $\mathrm{HCC}$ \\
\hline 92. & Very little chance at a social life & $\mathrm{PF}$ \\
\hline 93. & No definitive salary grid & Comp \\
\hline 94. & Sick & $\mathrm{PF}$ \\
\hline 95. & $\begin{array}{l}\text { Poor communication by Senior Managers with currently serving } \\
\text { ff members in leadership roles on recruitment }\end{array}$ & $\overline{\mathrm{AL}}$ \\
\hline 96. & $\begin{array}{l}\text { Non-educator owners calling the academic shots, totally ignorant } \\
\text { he consequences }\end{array}$ & $\begin{array}{l}\text { "Private } \\
\text { ownership }\end{array}$ \\
\hline 97. & No involvement in school decision making & $\mathrm{AL}$ \\
\hline 98. & Where located in the world & $\mathrm{PF}$ \\
\hline 99. & Partner wanted to return to Canada. & PF \\
\hline 100. & Treatment of our own children & PF \\
\hline 101. & Quality of personal life & $\mathrm{PF}$ \\
\hline 102. & New experiences inciuding languages & PF \\
\hline 103. & Further leadership opportunities & $\overline{P A}$ \\
\hline 104. & Unwillingness of head to keep up to date with current initiatives & $\mathrm{AL}$ \\
\hline 105. & Needed my Masters to renew my license & $\mathrm{PA}$ \\
\hline 106. & Wanted a change & $\overline{\mathrm{PF}}$ \\
\hline 107. & Lack of resources & WC \\
\hline 108. & $\begin{array}{l}\text { Amount of curriculum development required to bring the } \\
\text { condary courses up to a reasonable IBMYP and DP standard. }\end{array}$ & $\overline{A S}$ \\
\hline 109. & Lack of facilities & WC \\
\hline \multicolumn{3}{|l|}{110} \\
\hline 111. & Lack of empowerment & $\mathrm{AL}$ \\
\hline 112. & Nothing more & *Ambig \\
\hline 113. & Pay & Comp \\
\hline \multicolumn{3}{|l|}{114.} \\
\hline 115. & Ugly housing & $\mathrm{HCC}$ \\
\hline 116. & Professional development & $\overline{W C}$ \\
\hline \multicolumn{3}{|l|}{117.} \\
\hline 118. & Lack of Professionalism among senior members of staff & $\overline{\mathrm{AL}}$ \\
\hline $\begin{array}{r}119 . \\
\end{array}$ & $\begin{array}{l}\text { Instability of the school because of problems with local } \\
\text { ernment }\end{array}$ & $\mathrm{HCC}$ \\
\hline 120. & The lack of discipline from students & SD \\
\hline \multicolumn{3}{|l|}{121.} \\
\hline 122. & Housing & $\mathrm{HCC}$ \\
\hline 123. & Need for new challenges & $\mathrm{PF}$ \\
\hline 124. & Admin with lack of vision for school & $\mathrm{AL}$ \\
\hline 125. & $\mathrm{~N}$ & $\overline{\mathrm{PF}}$ \\
\hline \multicolumn{3}{|l|}{126.} \\
\hline 127. & O (from above) & PA \\
\hline 128. & Further study & $\mathrm{PA}$ \\
\hline
\end{tabular}




\begin{tabular}{|c|c|c|}
\hline 129. & Pollution & $\mathrm{HCC}$ \\
\hline 130. & Appalling behavior of head teacher & $\mathrm{AL}$ \\
\hline 131. & Benefits and packages offered by the school & Comp \\
\hline 132. & Language barriers & $\mathrm{HCC}$ \\
\hline 133. & Lack of parental support & WC \\
\hline 134. & Jekyll and Hyde administrator & $\mathrm{AL}$ \\
\hline 135. & Professional development & WC \\
\hline 136. & Lack of leadership & $\mathrm{AL}$ \\
\hline 137. & Had only planned to be there 2 years. & $\mathrm{PF}$ \\
\hline 138. & Professional development & WC \\
\hline 139. & Lack of prospects & PA \\
\hline 140. & Country was hard to get to & $\mathrm{HCC}$ \\
\hline 141. & Dishonest principal & $\mathrm{AL}$ \\
\hline 142. & Response deleted - participant ineligible & \\
\hline 143. & Poor accommodation & $\overline{\mathrm{HCC}}$ \\
\hline 144. & Compensation package & Comp \\
\hline 145. & Living environment & $\mathrm{HCC}$ \\
\hline \multicolumn{3}{|l|}{146.} \\
\hline 147. & Resource availability & WC \\
\hline 148. & No pension plan or long term gratuity & Comp \\
\hline 149. & Behavior of students & SD \\
\hline 150. & I am expecting a baby & $\mathrm{PF}$ \\
\hline $\begin{array}{r}151 . \\
r\end{array}$ & $\begin{array}{l}\text { The new administration expected us to see out our year contracts } \\
\text { ardless of recruitment procedures }\end{array}$ & $\begin{array}{l}\text { *Misrepres- } \\
\text { sentation }\end{array}$ \\
\hline 152. & Lack of free education for my children & Comp \\
\hline 153. & Wanted to see a new country & PF \\
\hline 154. & Lack of resources, poor overall compensation package & WC, Comp \\
\hline 155. & (1, & *Ambig \\
\hline $\begin{array}{r}156 . \\
f i\end{array}$ & $\begin{array}{l}\text { They didn't support me while I was on maternity leave. I had to } \\
\text { it for my paid leave and in the end did not get what I was entitled to. }\end{array}$ & $\overline{A L}$ \\
\hline & ( & WC \\
\hline $\begin{aligned} 158 . \\
\mathrm{ti}\end{aligned}$ & $\begin{array}{l}\text { Felt I had contributed a lot to the school already and now it was } \\
\text { e for new teachers to come in }\end{array}$ & $\mathrm{PF}$ \\
\hline 159. & See 18 above & \\
\hline 160. & Quality of personal life & $\mathrm{PF}$ \\
\hline 161. & Cultural differences too different to consider long term placement & $\mathrm{HCC}$ \\
\hline 162. & Personal Reasons & $\mathrm{PF}$ \\
\hline 163. & Respect from Elementary Principal & $\mathrm{AL}$ \\
\hline \multicolumn{3}{|l|}{164.} \\
\hline 165. & Lack of leadership opportunities & $\overline{\mathrm{PA}}$ \\
\hline 166. & Package & Comp \\
\hline & Compensation & Comp \\
\hline $\begin{array}{r}168 . \\
c\end{array}$ & $\begin{array}{l}\text { Amazing job opportunity at another international school in another } \\
\text { Intry, and double the salary! }\end{array}$ & Comp, PA \\
\hline 169. & The city of & $\mathrm{HCC}$ \\
\hline 170. & Lack of promotion prospects & $\mathrm{PA}$ \\
\hline 171. & Incompetent SMT & $\mathrm{AL}$ \\
\hline 172. & Teaching assignments & $\overline{W C}$ \\
\hline
\end{tabular}




\begin{tabular}{|c|c|c|}
\hline 173. & I did not agree with the discipline at the school & $\mathrm{SD}$ \\
\hline & Lack of children & $\begin{array}{l}\text { "Low student } \\
\text { numbers }\end{array}$ \\
\hline 175. & Support from owners of the school & $\begin{array}{l}{ }^{*} \text { Private } \\
\text { ownership }\end{array}$ \\
\hline 176. & Students & ${ }^{*}$ Ambig \\
\hline 177. & Personal & $\mathrm{PF}$ \\
\hline 178. & Cost of living and quality of living not as advertised & $\mathrm{HCC}$ \\
\hline 179. & Poor expectations of the children & Ambig \\
\hline & Taxation & $\mathrm{HCC}$ \\
\hline $\begin{array}{r}181 . \\
s\end{array}$ & $\begin{array}{l}\text { School advisory board was unprofessional and driven by blatant } \\
\text { f-interest }\end{array}$ & ${ }^{*}$ Board issues \\
\hline 182. & Only intended to stay 2 years/wanted to keep traveling & $\mathrm{PF}$ \\
\hline 183. & Lack of musical opportunities for my husband who is a musician & $\mathrm{PF}$ \\
\hline $\begin{array}{r}184 . \\
t\end{array}$ & $\begin{array}{l}\text { Staff not valued and contributions and opinions were not listened } \\
\text { or disregarded. }\end{array}$ & $\overline{\mathrm{AL}}$ \\
\hline 185. & Rather low salary & Comp \\
\hline 186. & Didn't feel appreciated by admin & $\mathrm{AL}$ \\
\hline 187. & Finding a new job before age 60 & $\mathrm{PF}$ \\
\hline 188. & Lack of support from Heads and Director & $\overline{\mathrm{AL}}$ \\
\hline 189. & Financial Package & Comp \\
\hline 190. & Desire to return to Spanish mainland (eventually) & $\mathrm{PF}$ \\
\hline \multicolumn{3}{|l|}{191.} \\
\hline 192. & $\begin{array}{l}\text { Frustration over lack of progress on certain problems not within my } \\
\text { wer to solve }\end{array}$ & $\overline{A L}$ \\
\hline & Family & $\mathrm{PF}$ \\
\hline & Lack of personal life & $\mathrm{PF}$ \\
\hline 195. & Lack of Resources & WC \\
\hline 196. & Possible future of the school & *Ambig \\
\hline & Work in a different culture & $\mathrm{PF}$ \\
\hline 198. & High Cost of Living & $\mathrm{HCC}$ \\
\hline \multicolumn{3}{|l|}{199.} \\
\hline & Wrongful dismissal of the school director & "Board issues \\
\hline & Feeling of professional isolation & WC \\
\hline & Lack of innovation and cross school scope and sequence. & $\mathrm{AL}$ \\
\hline & Family situation (inc. finance) & PF, Comp \\
\hline $\begin{array}{r}204 . \\
\text { a }\end{array}$ & $\begin{array}{l}\text { School was ruled as a profit making organization but without the } \\
\text { vantages (i.e. if you work well you get compensation) }\end{array}$ & $\begin{array}{l}\text { *Profit } \\
\text { incentive }\end{array}$ \\
\hline & High cost of Living & $\mathrm{HCC}$ \\
\hline 206. & $\begin{array}{l}\text { Lack of clarity in terms of employment, as far as originally stated } \\
\text { entional versus actual contract and workload }\end{array}$ & $\begin{array}{l}\text { "Misrepre- } \\
\text { sentation }\end{array}$ \\
\hline & Lack of support from Head teacher & $\mathrm{AL}$ \\
\hline $\begin{array}{r}208 . \\
5\end{array}$ & $\begin{array}{l}\text { School's educational philosophy did not meet the reality of its } \\
\text { dent population }\end{array}$ & "Ambig \\
\hline 209. & Lack of financial management and planning & $\overline{A L}$ \\
\hline 210. & Staff morale & $\overline{A L}$ \\
\hline 211. & Reduced financial package because of tax & Comp \\
\hline 212. & Time to see new part of world & $\mathrm{PF}$ \\
\hline 213. & Disorganized school & $\overline{\mathrm{AL}}$ \\
\hline
\end{tabular}




\begin{tabular}{|c|c|c|}
\hline \multicolumn{2}{|c|}{$\begin{array}{l}\text { 214. School was not 'diverse, with more than } 40 \text { nationalities' as } \\
\text { promised during interview process, but rather almost all } \\
\text { nationals. }\end{array}$} & \multirow{2}{*}{$\begin{array}{l}\text { "Misrepre- } \\
\text { sentation }\end{array}$} \\
\hline 215. & Nickel and diming with compensation & \\
\hline 216. & Lack of discipline for students & SD \\
\hline 217. & Money & Comp \\
\hline 218. & Poor salary package & Comp \\
\hline \multicolumn{3}{|l|}{219.} \\
\hline 220. & High taxes & $\mathrm{HCC}$ \\
\hline 221. & Stagnant staff (many teaching in school for $20+$ years) & $\begin{array}{l}\text { *Quality of } \\
\text { staff }\end{array}$ \\
\hline 222. & Inept principal who changed her daughter's grades & $\mathrm{AL}$ \\
\hline \multicolumn{3}{|c|}{ (1) } \\
\hline \multirow{2}{*}{\multicolumn{2}{|c|}{$\begin{array}{l}\text { schools themselves } \\
225 . \quad \text { Response deleted - participant ineligible }\end{array}$}} & $\overline{A L}$ \\
\hline & & \\
\hline 226. & There was no induction programme & $\mathrm{AL}$ \\
\hline \multicolumn{3}{|l|}{227.} \\
\hline 228. & Expectations Mismatch & $\mathrm{PF}$ \\
\hline 229. & School personally owned by upper administration & $\begin{array}{l}\text { "Private } \\
\text { ownership }\end{array}$ \\
\hline 230. & Years abroad did not count as years worked in home country & $\mathrm{PF}$ \\
\hline 231. & Lack of communication between admin and staff & $A L$ \\
\hline 232. & Negativity in the work environment & WC \\
\hline \multicolumn{3}{|c|}{ gasing } \\
\hline 234. & No resources for PYP & WC \\
\hline 235. & Complete lack of support from the administration & $\overline{A L}$ \\
\hline 236. & Strong Parental Influence at the School & WC \\
\hline 237. & Lack of leadership and professional environment & $\mathrm{AL}$ \\
\hline 238. & Miss other children/grandchildren & $\mathrm{PF}$ \\
\hline 239. & Expense of living & $\mathrm{HCC}$ \\
\hline 240. & Leave from Canadian school board not extended & $\mathrm{PF}$ \\
\hline 241. & Difficult leadership \& colleagues & $\mathrm{AL}$ \\
\hline 242. & Poor lodging & $\mathrm{HCC}$ \\
\hline \multicolumn{3}{|l|}{243.} \\
\hline 244. & School management and organization & $\mathrm{AL}$ \\
\hline 245. & To experience more variety & $\mathrm{PF}$ \\
\hline 246. & Academic quality & $\overline{A S}$ \\
\hline 247. & Return to home country & $\mathrm{PF}$ \\
\hline 248. & Poor Administrative Communication with Teachers & $\overline{A L}$ \\
\hline 249. & Better location & $\mathrm{PF}$ \\
\hline 250. & Style of management & $\overline{A L}$ \\
\hline 251. & A sense of being undervalued & $\overline{A L}$ \\
\hline \multicolumn{3}{|l|}{252.} \\
\hline 253. & Treatment by management & $\mathrm{AL}$ \\
\hline 254. & Head of School's attitude towards locally hired staff. & $\overline{A L}$ \\
\hline \multicolumn{3}{|l|}{255.} \\
\hline 256. & I did not like. & $\mathrm{PF}$ \\
\hline 257. & Wanted to return to UK & PF \\
\hline
\end{tabular}




\begin{tabular}{r|l}
\hline $258 . \quad$ Lack of communication from management & $\mathrm{AL}$ \\
\hline $\begin{aligned} 259 . \quad \text { Necessary to live in Europe if children are to be educated at EU } \\
\text { rates }\end{aligned}$ & $\mathrm{PF}$ \\
\hline $260 . \quad$ Fatigue & $\mathrm{PF}$ \\
\hline $261 . \quad$ Lack of any Professional Development & $\mathrm{WC}$ \\
\hline $262 . \quad$ Living conditions & $\mathrm{HCC}$ \\
\hline $263 . \quad$ Frustrations with administration & $\mathrm{AL}$ \\
\hline $264 . \quad$ Low salary & $\mathrm{Comp}$ \\
\hline $265 . \quad$ Friends were leaving the school & $\mathrm{PF}$ \\
\hline $266 . \quad$ Parent power undermined decisions made by teachers & $\mathrm{WC}$ \\
\hline $267 . \quad$ Felt like a change of culture & $\mathrm{PF}$ \\
\hline $268 . \quad$ Autocratic leadership & $\mathrm{AL}$ \\
\hline $269 . \quad$ Cost of living was increasing and the relative value of the package & $\mathrm{HCC}$ \\
was decreasing & \\
\hline $270 . \quad$ Response deleted - participant ineligible & \\
\hline $271 . \quad$ Instability of my responsibilities & WC \\
\hline $272 . \quad$ High taxes in & $\mathrm{HCC}$ \\
\hline $273 . \quad$ Too small & $\mathrm{PF}$ \\
\hline $274 . \quad$ Poor management & $\mathrm{AL}$ \\
\hline $275 . \quad$ Lack of resources/ teaching materials & WC \\
\hline $276 . \quad$ Mismatch between what I was told in interview and what the real & ${ }^{*}$ Misrepre- \\
situation was & sentation \\
\hline $277 . \quad$ Administrative lack of respect for staff and basic 'human rights' & $\mathrm{AL}$ \\
\hline $278 . \quad$ A verbal understanding never materialized & ${ }^{*}$ Misrepre- \\
\hline $279 . \quad$ Lifestyle in the country & sentation \\
\hline $280 . \quad$ Admin & $\mathrm{HCC}$ \\
\hline $281 . \quad$ Student Behavior & $\mathrm{AL}$ \\
\hline $282 . \quad$ Low pay & SD \\
\hline $283 . \quad$ Country too far from our own & Comp \\
\hline $284 . \quad$ Way decisions were made & $\mathrm{HCC}$ \\
\hline $285 . \quad$ Quality of Personal Life & $\mathrm{AL}$ \\
\hline $286 . \quad$ Incredibly corrupt leadership that actually steals money from the & $\mathrm{PF}$ \\
\hline teachers and state & $\mathrm{AL}$ \\
\hline
\end{tabular}


Question 19 c: "What were the top three reasons that prompted you to leave the school?"

\begin{tabular}{|c|c|c|}
\hline \multicolumn{2}{|c|}{ Respondent Number and written response } & $\begin{array}{l}\text { Causal Factor } \\
\text { Categories } \\
\end{array}$ \\
\hline 1. & 1 & WC \\
\hline 2. & Poor academic attitude displayed by students & SD \\
\hline 3. & Low academic standards of school & AS \\
\hline 4. & The pay was getting worse and worse with inflation & $\mathrm{HCC}$ \\
\hline 5. & Lack of support by admin & $\overline{A L}$ \\
\hline 6. & Careerism for profit & *Ambig \\
\hline \multicolumn{3}{|c|}{ 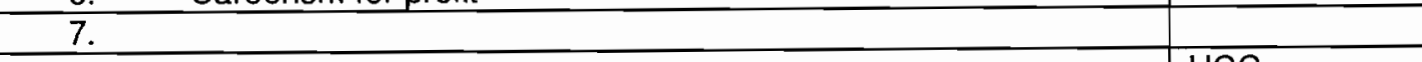 } \\
\hline 8. & Dangerous host country & $\mathrm{HCC}$ \\
\hline \multicolumn{3}{|c|}{ 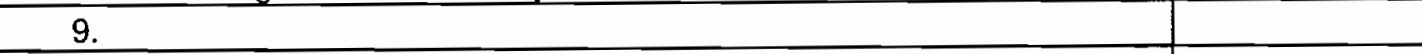 } \\
\hline \multicolumn{3}{|l|}{10.} \\
\hline 11. & Desire to experience another culture & $\overline{P F}$ \\
\hline 12. & Desire to move on and see more & $\mathrm{PF}$ \\
\hline & $\begin{array}{l}\text { Equal and connected: seeking promotion/principal who } \\
\text { srespected staff caused friction between me and director (caught } \\
\text { n though!) }\end{array}$ & $\mathrm{AL}$ \\
\hline 14. & Need to return to UK system & $\overline{\mathrm{PF}}$ \\
\hline 15. & Dearth of opportunities for advancement & PA \\
\hline & $\begin{array}{l}\text { Decided to re-orient my teaching towards humanities, and enroll } \\
\text { do MA back in NZ }\end{array}$ & $\overline{P F}$ \\
\hline \multicolumn{3}{|l|}{17.} \\
\hline 18. & Poorly focused academic program & AS \\
\hline 19. & Negativity throughout the preexisting staff & *Staff issues \\
\hline 20. & Management & $\mathrm{AL}$ \\
\hline 21. & Salary & Comp \\
\hline 22. & Subject not really valued & $\mathrm{AL}$ \\
\hline 23. & 1 didn't feel safe in & $\mathrm{HCC}$ \\
\hline 24. & Retirement savings & Comp \\
\hline \multicolumn{3}{|l|}{25.} \\
\hline 26. & Country's Religion & $\mathrm{HCC}$ \\
\hline \multicolumn{3}{|l|}{27.} \\
\hline 28. & Poor health and quality of life & $\mathrm{PF}$ \\
\hline 29. & Less lying & "Ambig \\
\hline 30. & Poor resources $v$ huge profits & *Profit incentive \\
\hline \multicolumn{3}{|l|}{31.} \\
\hline 32. & Opportunities for professional development & WC \\
\hline \multicolumn{3}{|c|}{ - } \\
\hline \multicolumn{3}{|l|}{34.} \\
\hline 35. & No support from the above & $\overline{A L}$ \\
\hline 36. & Teachers are housed on campus & $\mathrm{PF}$ \\
\hline 37. & No desire to remain in & $\overline{P F}$ \\
\hline 38. & Salary & Comp \\
\hline 39. & Required to teach non-major classes & WC \\
\hline \multicolumn{3}{|l|}{40.} \\
\hline 41. & American Bible ethos & "Ambig \\
\hline
\end{tabular}




\begin{tabular}{|c|c|c|}
\hline 42. & & \\
\hline \multicolumn{3}{|l|}{43.} \\
\hline 44. & dictatorial owner & $\begin{array}{l}{ }^{*} \text { Private } \\
\text { ownership }\end{array}$ \\
\hline 45. & Had traveled all over & PF \\
\hline \multicolumn{3}{|c|}{ 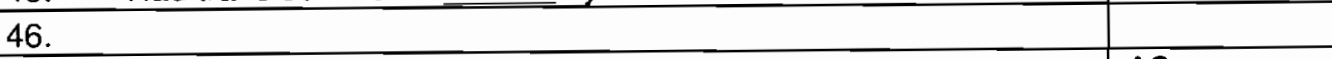 } \\
\hline 47. & Quality of Curriculum & AS \\
\hline 48. & Lack of leadership by the head of school & $\mathrm{AL}$ \\
\hline \multicolumn{3}{|l|}{49.} \\
\hline & $\begin{array}{l}\text { Admin. was not honest about cost of living in host country - e.g. } \\
\text { ts and auto costs. }\end{array}$ & *Misrep \\
\hline 51. & No additional benefits to compensate for loss from taxes & Comp \\
\hline & $\begin{array}{l}\text { Lack of career advancement opportunities in the foreseeable } \\
\text { ure }\end{array}$ & PA \\
\hline 53. & Over worked & WC \\
\hline \multicolumn{3}{|l|}{54.} \\
\hline 55. & More singles-social life & PF \\
\hline 56. & Very low salary & Comp \\
\hline 57. & Low academic standards & AS \\
\hline 58. & Clientele & *Ambig \\
\hline 59. & Lack of PD & WC \\
\hline 60. & Cost of living in host city & $\mathrm{HCC}$ \\
\hline \multicolumn{3}{|l|}{61.} \\
\hline 62. & Many teachers being fired unreasonably. & $\overline{\mathrm{AL}}$ \\
\hline 63. & Expectations of teacher were not met. & "Ambig \\
\hline 64. & Board (including __ ambassador) lied to staff & *Board issues \\
\hline 65. & Facilities & WC \\
\hline & $\begin{array}{l}\text { For profit educational system that allowed rich boys to do what } \\
\text { y wanted }\end{array}$ & SD \\
\hline 67. & Location -2 years was enough & $\mathrm{PF}$ \\
\hline 68. & Lack of personal freedom in city & $\mathrm{HCC}$ \\
\hline 69. & Lies and manipulation about above from owners. & $\begin{array}{l}\text { *Private } \\
\text { ownership }\end{array}$ \\
\hline 70. & Financial & Comp \\
\hline 71. & Lack of care or concern for the staff needs & $\overline{\mathrm{AL}}$ \\
\hline \multicolumn{3}{|l|}{72.} \\
\hline 73. & The poor quality of other teachers & *Staff issues \\
\hline \multicolumn{3}{|c|}{ 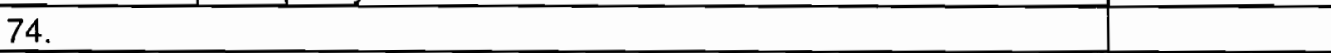 } \\
\hline 75. & I had lost all self confidence in my ability to teach & PF \\
\hline 76. & Social life & $\mathrm{PF}$ \\
\hline 77. & No resources to teach with & WC \\
\hline 78. & Wish to move elsewhere & $\overline{P F}$ \\
\hline 79. & Package - paid in US dollars & Comp \\
\hline 80. & Response deleted - participant ineligible & \\
\hline 81. & Standards in all areas were poor & AS \\
\hline \multicolumn{3}{|l|}{82.} \\
\hline & $\begin{array}{l}\text { Poor communication, poor management. The founder would not } \\
\text { en to the teachers at all. Inappropriate curriculum. }\end{array}$ & AL, $\overline{A S}$ \\
\hline 84. & & \\
\hline
\end{tabular}




\begin{tabular}{|c|c|c|}
\hline 85. & Geographic isolation & $\mathrm{HCC}$ \\
\hline 86. & Cultural & $\mathrm{HCC}$ \\
\hline 87. & Challenging student behaviors & SD \\
\hline 88. & Personal Relationship strains & $\overline{\mathrm{PF}}$ \\
\hline 89. & Lack of resources & WC \\
\hline 90. & $\mathrm{~K}$ & Comp \\
\hline \multicolumn{3}{|l|}{91.} \\
\hline 92. & Weather & $\mathrm{HCC}$ \\
\hline 93. & Change in personal circumstances (birth of 1 st child) & $\mathrm{PF}$ \\
\hline 94. & Difficult staff member & *Staff issues \\
\hline 95. & Poor facilities and resources combined with the above. & WC \\
\hline Western. & $\overline{\text { stern. }}^{-}$life, very boring and a social environment that was anti- & $\mathrm{HCC}$ \\
\hline 97. & Weak leadership & $\overline{A L}$ \\
\hline 98. & Feelings of safety & $\mathrm{HCC}$ \\
\hline \multicolumn{2}{|c|}{ overseas. } & $\overline{\mathrm{PF}}$ \\
\hline 100. & Low salaries & Comp \\
\hline 101. & Seeking new challenge & $\mathrm{PF}$ \\
\hline 102. & The founder of the school used discriminate & "Ambig \\
\hline 103. & Quality of family life & $\mathrm{PF}$ \\
\hline 104. & Lack of resources & WC \\
\hline \multicolumn{3}{|l|}{105.} \\
\hline 106. & Wanted to have more time at my home in NZ & $\mathrm{PF}$ \\
\hline 107. & Lies from alleged senior management & $\mathrm{AL}$ \\
\hline 108. & Lack of adequate technical support and specialist equipment. & WC \\
\hline 109. & Lack of promotion opportunities & $\mathrm{PA}$ \\
\hline \multicolumn{3}{|c|}{ 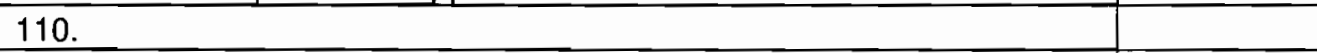 } \\
\hline 111. & Lack of professional development & WC \\
\hline 112. & Nothing more & *Ambig \\
\hline 113. & My age & PF \\
\hline \multicolumn{3}{|l|}{114.} \\
\hline 115. & Long commute & PF \\
\hline 116. & Communication with senior admin & $\mathrm{AL}$ \\
\hline \multicolumn{3}{|c|}{$=$} \\
\hline & Job Stability & ${ }^{*}$ Ambig \\
\hline \multicolumn{3}{|l|}{119.} \\
\hline \multicolumn{2}{|r|}{ didn't really fit } & $\mathrm{PF}$ \\
\hline \multicolumn{2}{|c|}{121.} & \\
\hline 122. & The family who runs/owns the school & $\begin{array}{l}{ }^{*} \text { Private } \\
\text { ownership }\end{array}$ \\
\hline \multicolumn{3}{|l|}{123.} \\
\hline 124. & Illness & $\mathrm{PF}$ \\
\hline 125. & A & $\mathrm{AL}$ \\
\hline \multicolumn{3}{|l|}{126.} \\
\hline 127. & $N($ from above) & $\mathrm{PF}$ \\
\hline 128. & Personal development & $\mathrm{PA}$ \\
\hline
\end{tabular}




\begin{tabular}{|c|c|}
\hline Age of children & $\overline{\mathrm{PF}}$ \\
\hline Lack of support from admin & $\mathrm{AL}$ \\
\hline Living accommodation & $\mathrm{HCC}$ \\
\hline General expectations of school & "Ambig \\
\hline Career advancement & PA \\
\hline Sexual harassment & $\begin{array}{l}{ }^{*} \text { Sexual } \\
\text { harassment }\end{array}$ \\
\hline A change of scenery & PF \\
\hline Lack of leadership & $\mathrm{AL}$ \\
\hline $\begin{array}{l}\text { 137. Established good friends there, but was feeling bored and } \\
\text { isolated in the location }\end{array}$ & $\mathrm{PF}$ \\
\hline 138. Greener pastures & $\mathrm{PF}$ \\
\hline Adventure & $\mathrm{PF}$ \\
\hline Wanted to be closer to family & PF \\
\hline Unhappy staff & ${ }^{*}$ Staff issues \\
\hline Response deleted - participant ineligible & \\
\hline Pollution & $\mathrm{HCC}$ \\
\hline Opportunities to advance & PA \\
\hline Management support & $\overline{A L}$ \\
\hline \multicolumn{2}{|l|}{146.} \\
\hline Student behavior & $\mathrm{SD}$ \\
\hline Accepted a much better offer in China & $\mathrm{PA}$ \\
\hline Loss of retirement benefits in USA & PF \\
\hline $150 . \quad$ is not a city I like & $\mathrm{HCC}$ \\
\hline $\begin{array}{l}\text { 151. I grew to dislike the school so intensely that I left myself no } \\
\text { alternative but to leave }\end{array}$ & PF \\
\hline 152. Back-stabbers & ${ }^{\star}$ Staff issues \\
\hline 153. Learn a new school system & $\mathrm{PF}$ \\
\hline 154. Poor alignment with curriculum philosophy & AS \\
\hline Lack of teacher support & $\mathrm{AL}$ \\
\hline The lack of resources and poorly maintained facilities. & WC \\
\hline 157. (G) & AS \\
\hline 158. Ready to see-live in new places & PF \\
\hline $\begin{array}{l}\text { 159. Slight feeling that the management of the school was struggling } \\
\text { to act professionally. }\end{array}$ & $\overline{\mathrm{AL}}$ \\
\hline 160. Living conditions & $\mathrm{HCC}$ \\
\hline $\begin{array}{l}\text { 161. Disappointments with relationship between classroom teachers, } \\
\text { managers and local owners }\end{array}$ & $\overline{\mathrm{AL}}$ \\
\hline 162. Administration & $\overline{\mathrm{AL}}$ \\
\hline Time to move on & PF \\
\hline \multicolumn{2}{|l|}{164.} \\
\hline 165. Mismatch between expectations and reality & $\mathrm{PF}$ \\
\hline 166. Personal & $\mathrm{PF}$ \\
\hline \multicolumn{2}{|l|}{167.} \\
\hline $\begin{array}{l}\text { 168. Exhausting schooi calendar in an exhausting, hot climate in a } \\
\text { congested city }\end{array}$ & $\overline{H C C}, W C$ \\
\hline 169. Career enhancement & PA \\
\hline 170. Rising tension in & HCC \\
\hline 171. Incompetent and interfering board of governors & *Board issues \\
\hline
\end{tabular}




\begin{tabular}{|c|c|c|}
\hline 172. & Lack of technology & WC \\
\hline 173. & I wanted to return to Europe after a numbers of years away & PF \\
\hline 174. & The director & $\mathrm{AL}$ \\
\hline 175. & Personal reasons & $\mathrm{PF}$ \\
\hline 176. & Quality of personal life & PF \\
\hline 177. & Money & Comp \\
\hline 178. & No chance to do the job I was hired for & *Misrep \\
\hline 179. & Lack of school improvement & *Ambig \\
\hline 180. & Taxation & $\mathrm{HCC}$ \\
\hline 181. & Unprofessionalism at every level & $\mathrm{AL}$ \\
\hline 182. & Looking for overall better comp. package & Comp \\
\hline 183. & Immediate supervisor was sometimes autocratic & $\overline{\mathrm{AL}}$ \\
\hline 184. & Work expectation too high, personnel support nonexistent. & WC \\
\hline 185. & Significant extracurricular workload & WC \\
\hline 186. & Big gap between faculty and other staff & ${ }^{*}$ Staff issues \\
\hline 187. & Poor level of collegiality & ${ }^{*}$ Staff issues \\
\hline 188. & Cost of living & $\mathrm{HCC}$ \\
\hline \multicolumn{3}{|l|}{189.} \\
\hline 190. & Bitchy, antagonistic atmosphere in staffroom & *Staff issues \\
\hline \multicolumn{3}{|c|}{ 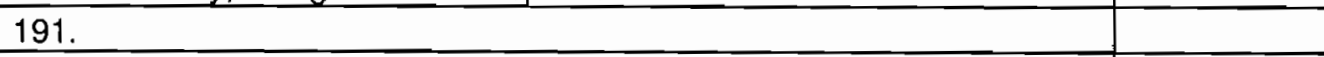 } \\
\hline 192. & In an rut & PF \\
\hline 193. & Emotional & $\mathrm{PF}$ \\
\hline 194. & Lack of professional advancement & $\mathrm{PA}$ \\
\hline 195. & Corrupted Employers & ${ }^{*} \mathrm{Ambig}$ \\
\hline \multicolumn{3}{|l|}{196.} \\
\hline 197. & Needed an overall break from (am heading back again!!) & $\mathrm{PF}$ \\
\hline 198. & Apartments were in need of facelift also the furnishings & $\mathrm{HCC}$ \\
\hline \multicolumn{3}{|l|}{199.} \\
\hline 200. & Very poor treatment of staff on the whole & $\overline{A L}$ \\
\hline 201. & Low wages & Comp \\
\hline 202. & $\begin{array}{l}\text { Poor/nonexistent assessment \& tracking or shared values in } \\
\text { at we were trying to achieve. }\end{array}$ & AS \\
\hline 203. & Privatization and structural changes & $\begin{array}{l}\text { *Private } \\
\text { ownership }\end{array}$ \\
\hline 204. & Administration and management not doing their job & $\mathrm{AL}$ \\
\hline & Wanted to continue education & $\overline{\mathrm{PF}}$ \\
\hline 206. & $\begin{array}{l}\text { Physical exhaustion from hard work in that school as well as } \\
\text { vious one coupled with psychological discouragement induced by } \\
\text { k of support and blatant discrimination suffered in the last school. }\end{array}$ & $\mathrm{PF}$ \\
\hline 207. & Uncertainty of school future & *Ambig \\
\hline $\begin{array}{r}208 . \\
\mathrm{a}\end{array}$ & $\begin{array}{l}\text { Lack of communication and trust between teachers and } \\
\text { ministrators }\end{array}$ & $\overline{\mathrm{AL}}$ \\
\hline $\begin{array}{r}209 . \\
n\end{array}$ & $\begin{array}{l}\text { Lack of honest communication between staff and senior } \\
\text { inagement }\end{array}$ & $\overline{\mathrm{AL}}$ \\
\hline 210. & Professional growth & $\overline{\mathrm{PA}}$ \\
\hline 211. & Attractive opportunity elsewhere & $\mathrm{PA}$ \\
\hline 212. & Change of leadership & $\mathrm{AL}$ \\
\hline 213. & Lack of discipline and support from administrators & $\mathrm{AL}$ \\
\hline 214. & Lack of international teaching experience and knowledge & *Staff issues \\
\hline
\end{tabular}




\begin{tabular}{|c|c|}
\hline amongst staff, who were almost all on their first overseas contract. & \\
\hline 215. Find better environment for daughter & $\mathrm{PF}$ \\
\hline Living conditions in host country & HCC \\
\hline Head & $\overline{A L}$ \\
\hline Poor development opportunities & PA \\
\hline \multicolumn{2}{|l|}{219.} \\
\hline Poor salary & Comp \\
\hline Lack of professional development & WC \\
\hline Violent student behavior without consequences & SD \\
\hline \multicolumn{2}{|l|}{223.} \\
\hline $\begin{array}{l}\text { 224. Severe lack of planning, forward-thinking and lack of 'big picture' } \\
\text { over the school year }\end{array}$ & $A L$ \\
\hline \multicolumn{2}{|l|}{$\begin{array}{l}\text { over the school year } \\
225 . \quad \text { Response deleted - participant ineligible }\end{array}$} \\
\hline $\begin{array}{l}\text { management and senior management was unaware of the work I } \\
\text { was doing }\end{array}$ & $\overline{A L}$ \\
\hline \multicolumn{2}{|l|}{227.} \\
\hline Support from parents and admin & $A L, W C$ \\
\hline Teachers not valued, seen as replaceable & $\mathrm{AL}$ \\
\hline Health insurance of home country did not apply & $\mathrm{PF}$ \\
\hline Lack of knowledge from admin to effect change & $A L$ \\
\hline Ineffective leadership & $\mathrm{AL}$ \\
\hline \multicolumn{2}{|l|}{233.} \\
\hline Impossible workload for the money & Comp \\
\hline Extremely low academic standards & $\overline{A S}$ \\
\hline High level of crime & $\mathrm{HCC}$ \\
\hline Lack of consistency & *Ambig \\
\hline Elderly father & $\overline{P F}$ \\
\hline 239. Quality of Life was poor in & $\mathrm{HCC}$ \\
\hline $\begin{array}{l}\text { 240. Taxation laws in changed affecting school salary and } \\
\text { benefits packages substantially }\end{array}$ & $\mathrm{HCC}$ \\
\hline Too heavy workload & WC \\
\hline incompetent administrators & $\overline{A L}$ \\
\hline \multicolumn{2}{|l|}{243.} \\
\hline Bad morale & *Staff issues \\
\hline 245. Rethink career goals & $\mathrm{PF}$ \\
\hline 246. Personal reasons & $\mathrm{PF}$ \\
\hline \multicolumn{2}{|l|}{247.} \\
\hline $\begin{array}{l}\text { 248. Unfair pay scale (i.e.: men paid more for doing the same job as } \\
\text { women) }\end{array}$ & $\begin{array}{l}\text { "Sexual } \\
\text { discrimination }\end{array}$ \\
\hline 249. Opportunity in other school & $\mathrm{PA}$ \\
\hline The way appointments were made internally & $\overline{A L}$ \\
\hline Internal politics & $\mathrm{AL}$ \\
\hline \multicolumn{2}{|l|}{252.} \\
\hline Lack of management support & $\overline{A L}$ \\
\hline \multicolumn{2}{|l|}{254.} \\
\hline \multicolumn{2}{|l|}{255.} \\
\hline There were no resources \& no support & $A L, W C$ \\
\hline
\end{tabular}




\begin{tabular}{|c|c|}
\hline $\begin{array}{l}\text { 257. Workload was becoming unsustainable as programme } \\
\text { developed }-6 \text { days a week, } 12+\text { hours most days and no intention to } \\
\text { hire additional staff to spare workload }\end{array}$ & WC \\
\hline \multicolumn{2}{|l|}{258.} \\
\hline New experiences in EU countries & $\mathrm{PF}$ \\
\hline Needed a change & $\mathrm{PF}$ \\
\hline Disregard for faculty's needs & $\overline{A L}$ \\
\hline Traveling opportunities & $\mathrm{PF}$ \\
\hline Insufficient resourcing & WC \\
\hline \multicolumn{2}{|l|}{264.} \\
\hline The weather in & $\mathrm{HCC}$ \\
\hline My father was terminally ill & $\mathrm{PF}$ \\
\hline Do new things & $\mathrm{PF}$ \\
\hline 268. Fast pace of change & $\mathrm{PF}$ \\
\hline There was no real opportunity for promotion & PA \\
\hline Response deleted - participant ineligible & \\
\hline Lack of support \& communication & $\overline{A L}$ \\
\hline 272. I was part-time teacher & $\mathrm{PF}$ \\
\hline 273. Ready to leave country & $\overline{\mathrm{PF}}$ \\
\hline 274. Attitude of management & $\overline{A L}$ \\
\hline Family reasons & $\mathrm{PF}$ \\
\hline $\begin{array}{l}\text { 276. Felt that the students were secondary to the need of the school } \\
\text { to find money to pay off loans }\end{array}$ & ${ }^{*}$ Profit incentive \\
\hline $\begin{array}{l}277 . \text { The difference between the philosophy of treating our students } \\
\text { and the way that staff are treated }\end{array}$ & $\overline{A L}$ \\
\hline 278. I could not be out of my professional niche any longer & $\mathrm{PF}$ \\
\hline Itchy feet & $\mathrm{PF}$ \\
\hline Pollution & $\mathrm{HCC}$ \\
\hline Parental Support & WC \\
\hline 282. Workload & $\overline{W C}$ \\
\hline Worried about the standard of medical care at the time & $\mathrm{PF}$ \\
\hline Life in the country & $\mathrm{HCC}$ \\
\hline 285. Salary and Benefit Package & Comp \\
\hline 286. Mediocre academic level at school & AS \\
\hline
\end{tabular}


Question 20: "Was there anything the school's administration could have done to prevent you from leaving the school that year?"

Question 21: "Please explain your answer for the above question (20)."

\begin{tabular}{|c|c|c|}
\hline Q. 20 & Q. 21 Respondent Number and written response & $\begin{array}{l}\text { Causal } \\
\text { Factor } \\
\text { Categories } \\
\end{array}$ \\
\hline No & They saw me as that year's sacrificial lamb, I didn't. & ${ }^{*}$ Ambig \\
\hline No & $\begin{array}{l}\text { 2. The management could not agree on any issue amongst } \\
\text { themselves, and was totally unaware of and disinterested in the } \\
\text { welfare and satisfaction of the staff, let alone the students. }\end{array}$ & $\mathrm{AL}$ \\
\hline Yes & $\begin{array}{l}\text { The country had limited interest for me. My personal life } \\
\text { outside the school was the main deciding factor. However, had } \\
\text { the academic standards been higher, I might have been tempted } \\
\text { to stay an extra year. }\end{array}$ & $\mathrm{PF}, \mathrm{AS}$ \\
\hline Yes & $\begin{array}{l}\text { I was working for two principals who did not seem to } \\
\text { communicate... both expecting me to do the job of a full-time } \\
\text { teacher for each of them... when they started to change their } \\
\text { attitude... it was too late... I was totally burned out! }\end{array}$ & $A L$ \\
\hline Yes & 5. Opportunities within the organization (career development) & $\mathrm{PA}$ \\
\hline No & They were the problem. & $\overline{\mathrm{AL}}$ \\
\hline No & 7. & \\
\hline No & $\begin{array}{l}\text { 8. Different mentality. USA \& my way cultural difference } \\
\text { perhaps. }\end{array}$ & "Ambig \\
\hline No & $\begin{array}{l}\text { I left for personal reasons and to train in a different field so } \\
\text { the decision was out of the hands of the school's administration. }\end{array}$ & $\overline{\mathrm{PA}, \mathrm{PF}}$ \\
\hline & 10. Response deleted, participant ineligible & \\
\hline Yes & $\begin{array}{l}\text { 11. See (a) above - knowing for sure that I had a stable position } \\
\text { at the school (before recruitment fairs) }\end{array}$ & *Ambig \\
\hline No & $\begin{array}{l}\text { 12. I wanted to leave } \\
\text { more sympathy with the culture and people. }\end{array}$ & $\mathrm{PF}$ \\
\hline Yes & $\begin{array}{l}\text { The director was very supportive from the start. The school } \\
\text { was undergoing immense change and I was responsible to } \\
\text { change part. Principal was very political and distrusting (had } \\
\text { own agenda). If he had changed or left I may have stayed } \\
\text { (especially if I had his job!). If the money had been better (e.g. } \\
\text { on a par with_ teachers) we could have stayed a bit longer - } \\
\text { e.g. } 5 \text { years). }\end{array}$ & $A L$, Comp \\
\hline No & $\begin{array}{l}\text { Ididn't see a long term future in US tradition schools, hence } \\
\text { need to find UK tradition school. US system schools don't } \\
\text { acknowledge UK qualifications fully - true for wife and myself }\end{array}$ & PF \\
\hline Yes & $\begin{array}{l}\text { 15. Recognition of innovative ideas and support for student } \\
\text { centered learning advancement }\end{array}$ & $\overline{\mathrm{AL}}$ \\
\hline No & $\begin{array}{l}\text { 1 spoke with the director of the school and he said he's try to } \\
\text { find me other responsibilities that would mean less English } \\
\text { teaching and marking, but by then the school itself and the } \\
\text { systems in place had frustrated me too much. Nothing could } \\
\text { change because the owner of the school is too involved in the } \\
\text { finances and education decisions are made on a purely financial } \\
\text { basis - i.e. accepting students into already crowded classrooms } \\
\text { without any real testing of English abilities. }\end{array}$ & $\begin{array}{l}\text { "Private } \\
\text { ownership }\end{array}$ \\
\hline No & There was nothing the school could do about my family's & $\mathrm{PF}$ \\
\hline
\end{tabular}




\begin{tabular}{|c|c|c|}
\hline & situation. & \\
\hline Yes & $\begin{array}{l}\text { 18. The new director was openly hostile to me and made it } \\
\text { pretty impossible to stay. }\end{array}$ & $\begin{array}{l}{ }^{\star} \text { Conflict } \\
\text { with admin }\end{array}$ \\
\hline No & $\begin{array}{l}\text { Nothing was going to change at the school as all decisions } \\
\text { were made by the board and the feeling was that all teachers } \\
\text { were replaceable. There were too many disgruntled staff who, } \\
\text { for whatever reasons, were unable to leave the school and that } \\
\text { created a very negative working environment. Decisions about } \\
\text { the educational program in the upper school were seldom made } \\
\text { with the student's best interest in mind, nor were they in line with } \\
\text { the accepted best practices. }\end{array}$ & $\mathrm{AL}$ \\
\hline No & 20. & \\
\hline Yes & $\begin{array}{l}\text { It was very lonely, group accommodation may have helped } \\
\text { for those who had come alone. Social events for expats. }\end{array}$ & $\mathrm{PF}$ \\
\hline Yes & $\begin{array}{l}\text { 22. Offering a bit more support to subject home leave once a } \\
\text { year }\end{array}$ & Comp \\
\hline Yes & $\begin{array}{l}\text { 23. Implemented a discipline policy and reinforce it. Support } \\
\text { their non-__ staff more. }\end{array}$ & $\mathrm{SD}, \mathrm{AL}$ \\
\hline No & $\begin{array}{l}\text { I was on the negotiation team that represented teachers in } \\
\text { their negotiations with the board regarding our compensation } \\
\text { passage. When the deal was finalized, there were } \\
\text { congratulations all around. However, when asked if I was happy } \\
\text { with the package, I told everyone that it was still not enough } \\
\text { money to live and that we would not sign the contract. It just } \\
\text { wasn't enough money. }\end{array}$ & Comp \\
\hline Yes & More support. & $\mathrm{AL}$ \\
\hline No & $\begin{array}{l}\text { 26. We wanted to move regardless of potential compensation or } \\
\text { job opportunities }\end{array}$ & PF \\
\hline Yes & 27. Higher pay and/or benefits & Comp \\
\hline Yes & $\begin{array}{l}\text { 28. Dealt with my requests/complaints re above in a fair and } \\
\text { appropriate manner, but basically ignored }\end{array}$ & $\mathrm{AL}$ \\
\hline Yes & $\begin{array}{l}\text { 29. I was being bullied into taking Head of Year } 10 \text { - sounds like } \\
\text { a good promotion and one I would have jumped at under normal } \\
\text { circumstances. But with an increase in teaching load from } 9 \text { to } \\
13 \text { classes, no extra time for that - including no time for the } \\
\text { Head of Year position I didn't believe I could carry out the duties } \\
\text { required. }\end{array}$ & $\overline{A L}$ \\
\hline No & 30. There was no professional development available & WC \\
\hline No & 31. & \\
\hline No & $\begin{array}{l}\text { 32. It was apparent that the status quo was going to remain and } \\
\text { the school just was not progressive enough for me. }\end{array}$ & $\mathrm{PF}$ \\
\hline Yes & $\begin{array}{l}\text { 33. If the level of support was of a professional standard I would } \\
\text { have stayed }\end{array}$ & $\overline{A L}$ \\
\hline No & $\begin{array}{l}\text { A total change in mentally would have been needed, which } \\
\text { wasn't going to happen. This is the way things are, the local } \\
\text { teachers accept it, its only the expats that find in unacceptable. }\end{array}$ & "Ambig \\
\hline Yes & $\begin{array}{l}\text { 35. Appointments (of new staff) were made without the positions } \\
\text { being openly advertised to all. }\end{array}$ & AL. \\
\hline No & 36. Not unless the director himself had left... & $\begin{array}{l}{ }^{*} \text { Conflict } \\
\text { with admin }\end{array}$ \\
\hline No & $\begin{array}{l}\text { 37. I wanted to teach in Europe and was prepared to go back to } \\
\text { the US if I did not get a job in Europe }\end{array}$ & PF \\
\hline Yes & $\begin{array}{l}\text { They could have been knowledgeable about education. } \\
\text { They could have been kind and caring individuals. They could }\end{array}$ & $\overline{A L}$ \\
\hline
\end{tabular}




\begin{tabular}{|c|c|c|}
\hline & have shared decision making and been respectful of their staff. & \\
\hline Yes & $\begin{array}{l}\text { 39. Administration asked to hire chemistry major to support my } \\
\text { teaching of IB biology }\end{array}$ & WC \\
\hline No & The school was closed by the proprietor. & $\begin{array}{l}\text { *School } \\
\text { closed }\end{array}$ \\
\hline No & $\begin{array}{l}\text { The lack of challenge, owing to low student numbers, was } \\
\text { something beyond the management's control. }\end{array}$ & $\begin{array}{l}\text { *Low } \\
\text { student } \\
\text { numbers }\end{array}$ \\
\hline Yes & $\begin{array}{l}\text { A large increase in salary. This was a long-time problem at } \\
\text { the school. The long term staff were very concerned that good } \\
\text { teachers were coming for two years and then leaving because } \\
\text { they literally could not live at any kind of decent standard. I was } \\
\text { in and the general feeling was that the salary could stay } \\
\text { low because teachers would almost pay the school for the } \\
\text { privilege of working in }\end{array}$ & Comp \\
\hline No & $\begin{array}{l}\text { 43. She was under assault as well-not being British in a school } \\
\text { run by them, but where the majority of the students were not- } \\
\text { and where the owner allowed her to be attacked in meetings } \\
\text { was difficult for her. She tried for us both. }\end{array}$ & $\begin{array}{l}{ }^{*} \text { Private } \\
\text { ownership }\end{array}$ \\
\hline No & Wanted to see other parts of the world & $\mathrm{PF}$ \\
\hline Yes & $\begin{array}{l}\text { 45. Offered overseas status to my husband and I. Just because } \\
\text { I was hired locally does not mean I am worth less as a teacher. I } \\
\text { accepted one year under those conditions, but could not accept } \\
\text { a second. }\end{array}$ & $\begin{array}{l}{ }^{*} \text { Contract } \\
\text { issues }\end{array}$ \\
\hline No & $\begin{array}{l}\text { 46. The school did not have the position I was seeking, and they } \\
\text { could not have further improved the living conditions (cost of } \\
\text { child care, opportunities for young children, and cost of private } \\
\text { help ie. cooking and cleaning). }\end{array}$ & $\mathrm{HCC}$ \\
\hline No & 47. Too many areas that needed attention. & "Ambig \\
\hline Yes & $\begin{array}{l}\text { 48. If the tax laws had been explained to us properly in the first } \\
\text { place, I would have known how to handle the situation and may } \\
\text { not have left. Also, the head of school could have said that l'd be } \\
\text { able to go on a professional development course the following } \\
\text { year (which she had promised at my initial interview and then } \\
\text { not followed through with). }\end{array}$ & "Misrep \\
\hline No & It was not related to the school & PF \\
\hline Yes & $\begin{array}{l}\text { 50. Administration is very much run by the Principal with some } \\
\text { input from Jr. and Sr. Vice Principal with very little input from } \\
\text { MYP an PYP coordinators. Every decision is basically a financial } \\
\text { one, with priority on keeping the seats filled and keeping } \\
\text { expenses to a minimum. }\end{array}$ & $\begin{array}{l}\text { *Profit } \\
\text { incentive }\end{array}$ \\
\hline No & $\begin{array}{l}\text { D1. Don't know. Reasons center around tax laws. No effort } \\
\text { seems to be made to retain good teachers. If additional benefits } \\
\text { to compensate for tax on children's tuition, could have been } \\
\text { reconsidered. Basically, school can go out and find } \\
\text { replacements so why try and retain teachers. }\end{array}$ & Comp \\
\hline Yes & $\begin{array}{l}\text { 52. Given me the same leadership opportunity that I have now } \\
\text { at another school }\end{array}$ & PA \\
\hline No & Management wanted clear-out of previous staff. & $\begin{array}{l}\text { "Clear-out } \\
\text { of staff }\end{array}$ \\
\hline No & 54. & \\
\hline No & Was looking for a new opportunity & $\mathrm{PF}$ \\
\hline Yes & $\begin{array}{l}\text { 56. If only the administrators were supportive and professionals } \\
\text { then I could have stayed longer than my signed contract of } 2\end{array}$ & $\overline{A L}$ \\
\hline
\end{tabular}




\begin{tabular}{|c|c|c|}
\hline & years. & \\
\hline No & 57. & \\
\hline Yes & $\begin{array}{l}\text { A8. more competitive salary and housing. I had to supplement } \\
\text { my salary with my savings to work there. No chance for } \\
\text { retirement savings on that income. }\end{array}$ & Comp \\
\hline Yes & $\begin{array}{l}\text { A9. A status change to "overseas foreign hire," or partial } \\
\text { equivalent, would have made a significant difference. A more } \\
\text { realistic salary would have also influenced my decision. }\end{array}$ & Comp \\
\hline Yes & 60. Offered more support in crisis situations & $\mathrm{AL}$ \\
\hline Yes & $\begin{array}{l}\text { They could have recognized the talent of experienced } \\
\text { educators and not discriminated against them. They actually did } \\
\text { not have any idea how valuable experience was to their } \\
\text { students and school. }\end{array}$ & $\overline{\mathrm{AL}}$ \\
\hline Yes & $\begin{array}{l}\text { a) Move teachers into reasonable housing ASAP. Living on } \\
\text { a construction site is NOT acceptable. b) Apologize profusely for } \\
\text { the insulting manner in which we were treated. c) Stop firing } \\
\text { teachers at the drop of a hat and stop letting students and their } \\
\text { parents run the school. d) Stop lying and lose the arrogance. }\end{array}$ & $\mathrm{AL}$ \\
\hline Yes & $\begin{array}{l}\text { The administration could have been more transparent to the } \\
\text { financial situation of the school. }\end{array}$ & $\overline{A L}$ \\
\hline Yes & $\begin{array}{l}\text { Paid me and gave me the housing promised. Not broken the } \\
\text { contracts of other staff apologized for lying to me and } \\
\text { compensated me. }\end{array}$ & $\begin{array}{l}\text { "Misrep, } \\
\text { Comp }\end{array}$ \\
\hline Yes & $\begin{array}{l}\text { Expansion of CAS programme and greater consideration for } \\
\text { staff welfare/remuneration. very conservative board of directors }\end{array}$ & $\mathrm{AL}, \mathrm{Comp}$ \\
\hline Yes & $\begin{array}{l}\text { The administrator could have included the "old" staff in on } \\
\text { the discussions and decision making particularly regarding the } \\
\text { signing and resigning of contracts }\end{array}$ & AL \\
\hline Yes & $\begin{array}{l}\text { Been more honest about employment opportunities for } \\
\text { spouse. }\end{array}$ & *Misrep \\
\hline No & $\begin{array}{l}\text { 68. As I stated in } 918 \text {, the administration / management etc. was } \\
\text { second to none. My personal freedom as a western woman in a } \\
\text { strict _ society was hampered and I felt vulnerable with } \\
\text { increased terrorist attacks. }\end{array}$ & $\overline{\mathrm{HCC}}$ \\
\hline Yes & $\begin{array}{l}\text { 69. Owners to pay their tax component for employees. We were } \\
\text { 'Self Employed', 'Directors of the School' - but this was covered } \\
\text { up! 'Teachers of English'. For these three reasons we paid no } \\
\text { tax or social security for the first two years. This kept profits up } \\
\text { and the owners have opened two further schools on the back of } \\
\text { the profits. }\end{array}$ & $\begin{array}{l}\text { *Misrep, } \\
\text { Profit } \\
\text { incentive, } \\
\text { Comp }\end{array}$ \\
\hline Yes & $\begin{array}{l}\text { They could have supported me as a teacher instead they } \\
\text { simply made decisions and ran things that catered to their } \\
\text { needs. So I as a teacher wasn't in the equation at all in their } \\
\text { decision making process. }\end{array}$ & $\overline{A L}$ \\
\hline Yes & $\begin{array}{l}\text { 71. They should have let the head of school do his job and } \\
\text { make the decisions that needed to be made. They should have } \\
\text { been more honest when hiring staff about work conditions and } \\
\text { what their jobs would actually be. They could have a contract } \\
\text { that is compatible with the other major international school in } \\
\text { that city. }\end{array}$ & $\begin{array}{l}\text { "Private } \\
\text { ownership } \\
\text { Misrep }\end{array}$ \\
\hline No & 72. & \\
\hline No & Too much water under the bridge by the end of two years & Ambig \\
\hline No & sec & \\
\hline Yes & The Principal could have been more positive in her & $\overline{\mathrm{AL}}$ \\
\hline
\end{tabular}




\begin{tabular}{|c|c|c|}
\hline & $\begin{array}{l}\text { comments and ways with the teachers and specifically me. A lot } \\
\text { of the things I did in my teaching were run down so that I felt } \\
\text { useless, particularly in my second year of the two year contract. }\end{array}$ & \\
\hline No & School was too hidebound. Turning the QE2 & $\begin{array}{l}{ }^{*} \text { School } \\
\text { too set in } \\
\text { ways }\end{array}$ \\
\hline Yes & $\begin{array}{l}\text { They could have asked each of the teachers to sign another } \\
\text { contract. I felt as though they did not want any teachers to stay. }\end{array}$ & $\begin{array}{l}{ }^{*} \text { Clear-out } \\
\text { of staff }\end{array}$ \\
\hline No & 78. & \\
\hline Yes & $\begin{array}{l}\text { 79. Communication could have been improved and decisions } \\
\text { could have been made. Once decisions were made, they would } \\
\text { get feed back and change decisions. The constant changing of } \\
\text { decisions was mind boggling and confusing. I say make a } \\
\text { decision and standby it, then ask for feedback at the end of the } \\
\text { year. Don't change every two months. Plus, with the dollar } \\
\text { growing weaker and weaker.... my salary would not have kept } \\
\text { up with deflation of the dollar. }\end{array}$ & $\mathrm{AL}, \mathrm{Comp}$ \\
\hline & 80. $\quad$ Response deleted, participant ineligible. & \\
\hline No & $\begin{array}{l}\text { 81. The facility was crumbling and dirty. My section principal } \\
\text { was disorganized and unresponsive to faculty concerns. The IT } \\
\text { Dept was reactive instead of proactive and their server space } \\
\text { was extremely limited. Consequently, the quality of life for the } \\
\text { faculty during the day was poor. }\end{array}$ & WC, AL \\
\hline No & $\begin{array}{l}\text { 82. I was ready to move on, really wanted to go back to school } \\
\text { and study full time as a result of my experience. I wanted to } \\
\text { understand further education theory, and figure out where I fit. }\end{array}$ & PF \\
\hline Yes & $\begin{array}{l}\text { 83. If she had met my request for salary, I would have stayed } \\
\text { and taken on a leadership role, since ALL (but one) of the other } \\
\text { ex-pat teachers were also leaving. I knew it would be difficult, } \\
\text { but at least I would be getting paid close to my US salary. }\end{array}$ & Comp \\
\hline Yes & Class load and subjects taught & WC \\
\hline No & I was single male in early 30 's in a female poor culture & $\mathrm{PF}$ \\
\hline No & 86. & \\
\hline Yes & $\begin{array}{l}\text { Before my two year contract was completed I was invited for } \\
\text { a 3rd year at the school. I proposed working } 66 \% \text { of a full time } \\
\text { contract, as I enjoyed my work but it was just too exhausting } \\
\text { teaching art full time at the schools. I was teaching at two } \\
\text { different schools, elementary for one and middle school for the } \\
\text { other. My headmaster declined my proposition, so I gave notice } \\
\text { that I was not renewing my contract at the end of the two years. } \\
\text { I think the school could not afford to have part time foreign } \\
\text { teachers as it would be a strain on budget to cover the housing } \\
\text { and health insurance for someone not employed full time. I } \\
\text { offered to work part time as a "local hire" but the head felt the } \\
\text { salary would not be sufficient for me to afford a middle class life } \\
\text { style in } \longrightarrow \text { and he stated he did not want to "set precedent" } \\
\text { by hiring me, a foreigner, in this manner. }\end{array}$ & $\begin{array}{l}{ }^{*} \text { Contract } \\
\text { issues }\end{array}$ \\
\hline Yes & $\begin{array}{l}\text { 88. Possibly, if I had not felt so targeted and unsupported early } \\
\text { on I may not have looked elsewhere. }\end{array}$ & $\overline{A L}$ \\
\hline No & $\begin{array}{l}\text { 89. I hated working in a private school who only cared about } \\
\text { making money, not the education of the children. }\end{array}$ & $\begin{array}{l}{ }^{*} \text { Profit } \\
\text { incentive }\end{array}$ \\
\hline No & $\begin{array}{l}\text { A0. change in school administration was the only thing that } \\
\text { would have made me stay and that was hardly likely to happen. } \\
\text { However, it did happen two years later but I was happy where I }\end{array}$ & $\overline{\mathrm{AL}}$ \\
\hline
\end{tabular}




\begin{tabular}{|c|c|c|}
\hline & had moved to so did not return to the "old school". & \\
\hline No & $\begin{array}{l}\text { 91. Enrollment was very low so the school was not in a position } \\
\text { to improve the package }\end{array}$ & Comp \\
\hline No & $\begin{array}{l}\text { 92. As stated in question } 18, \text { the school was simply not the best } \\
\text { location for a young, single woman. }\end{array}$ & PF \\
\hline Yes & $\begin{array}{l}\text { S3. Salary recognizing my position of responsibility as IT } \\
\text { Coordinator }\end{array}$ & Comp \\
\hline Yes & $\begin{array}{l}\text { 94. Not leave me in a hospital for days without anyone to } \\
\text { translate. Give me some support rather than guilt when I asked } \\
\text { for help. }\end{array}$ & $\mathrm{AL}$ \\
\hline Yes & $\begin{array}{l}\text { Apologized profusely and changed the job and role } \\
\text { description of the new staff member (the person who had been } \\
\text { employed with the same job and person description as I had } \\
\text { been holding at the time of their recruitment) }\end{array}$ & $\begin{array}{l}\text { "Contract } \\
\text { issues }\end{array}$ \\
\hline Yes & $\begin{array}{l}\text { 96. They could have let the professionals run the school. They } \\
\text { also could have tried encouraging the Arabic staff to connect } \\
\text { with their expatriate counterparts. }\end{array}$ & $\begin{array}{l}\text { *Private } \\
\text { ownership }\end{array}$ \\
\hline Yes & $\begin{array}{l}\text { 97. Clear school policies and transparency between staff pay } \\
\text { and conditions. A promotional growth structure, which is actively } \\
\text { encouraged and remunerated. }\end{array}$ & Comp \\
\hline No & $\begin{array}{l}\text { 98. It was time to move out of the country. If the school had } \\
\text { been in another country I may have decided to stay longer. }\end{array}$ & $\mathrm{HCC}$ \\
\hline No & $\begin{array}{l}\text { 99. It would not have been possible for admin. to fix pollution } \\
\text { problems in the city, or to change my partner's mind. }\end{array}$ & $\mathrm{HCC}$ \\
\hline Yes & $\begin{array}{l}\text { The hardest thing for my husband and me (we both taught } \\
\text { at the school) was the dishonesty, the lies of the director and } \\
\text { other management team members and the influence of the } \\
\text { board. We found it very difficult to work in an environment where } \\
\text { lies, dishonesty and secrecy were the norm. For example my } \\
\text { husband had to redo the entire computer network and worked } \\
\text { many long hours in the first few months we were there. He was } \\
\text { called into the principal's office and was told that his hard work } \\
\text { was greatly appreciated and that the board's secretary (who was } \\
\text { there too) affirmed that my husband would get an additional } \\
\text { 2000 euros to offset our children's tuition cost. He would get } \\
\text { paid at the end of the school year. The end of the school year } \\
\text { came and went and the director was very sorry but he had tried } \\
\text { and it just couldn't be done. Later we heard from a board } \\
\text { member that he had never brought up the issue. Another } \\
\text { example is the fact that we did not get paid the same salary } \\
\text { every month which we thought was very strange. There was no } \\
\text { transparency. Everything was cloaked in secrecy. When the } \\
\text { teachers tried to negotiate a higher salary they were told to } \\
\text { either take what the board was offering them or be put on an } \\
\text { teacher's salary which was even lower than what we } \\
\text { were earning. That smelled like blackmail to us. Often the truth } \\
\text { was not told, or not completely. After we had signed the contract } \\
\text { and had traveled to } \\
\text { teaching duties we had to do } 200 \text { minutes of } \\
\text { playground/lunchroom duty. As if that wasn't enough, the times } \\
\text { that we were out sick or on a field trip, those minutes that we } \\
\text { were not on duty would be deducted from our salary. We } \\
\text { stumbled upon this on accident. Most of our } \\
\text { not speak English. Meetings would switch into } \\
\text { translation. The language in the teacher's lounge was } \\
\text { without }\end{array}$ & $\begin{array}{l}\text { *Misrep, } \\
\text { Private } \\
\text { ownership, } \\
\text { AL }\end{array}$ \\
\hline
\end{tabular}




\begin{tabular}{|c|c|c|}
\hline & $\begin{array}{l}\text { Some of these colleagues had been at the school for more than } \\
15 \text { years. We didn't understand why the administration didn't } \\
\text { require them to learn some basic English. The school provided a } \\
\text { course for international teachers during our } 2 \text { nd year. We } \\
\text { found the school to be the most unprofessional school we had } \\
\text { ever taught at. The board and the parents ruled the school and } \\
\text { the director made sure he did whatever the board and the } \\
\text { parents wanted. A real shame, since the school has great } \\
\text { potential. We heard that in } 2007 \text { almost the entire elementary } \\
\text { school staff left, and } 3 \text { of the } 6 \text { administrators. Being open, } \\
\text { honest and up front with everything (realizing that you cannot } \\
\text { always share everything) would already go a long way towards } \\
\text { keeping the teachers. }\end{array}$ & \\
\hline No & 101. & \\
\hline No & $\begin{array}{l}\text { 102. The admin was great. It was the propriety of the school that } \\
\text { was suspect. }\end{array}$ & \begin{tabular}{|l|}
${ }^{*}$ Private \\
ownership
\end{tabular} \\
\hline Yes & $\begin{array}{l}\text { 103. Improved benefits for husband in a Senior Management } \\
\text { position eg housing allowance; furnished accommodation. }\end{array}$ & Comp \\
\hline Yes & $\begin{array}{l}\text { 104. The head surrounded herself with sycophants and any } \\
\text { professional staff were not valued at all. Opinions and advice } \\
\text { were belittled, as were people who dared to disagree with } \\
\text { anything of any nature within the school and the welfare of the } \\
\text { children. }\end{array}$ & $\mathrm{AL}$ \\
\hline Yes & $\begin{array}{l}\text { 105. I was working at a private, religious school that was giving a } \\
\text { salary. However, the school attendance was low and so they } \\
\text { went to a raising of money for the teachers - a kind of volunteer } \\
\text { teaching. }\end{array}$ & $\begin{array}{l}\text { *Contract } \\
\text { issues }\end{array}$ \\
\hline Yes & $\begin{array}{l}\text { 106. Offered an incentive bonus to stay another contract and } \\
\text { improved the package }\end{array}$ & Comp \\
\hline No & $\begin{array}{l}\text { 107. School was for profit only - the wool was pulled over } \\
\text { teachers eyes from day one and over the parents too. Most } \\
\text { teachers stayed due to the lifestyle outside work. School has } \\
\text { had (honestly) } 7 \text { principals in } 3 \text { years and } 6 \text { in the last } 2 \text {. Large } \\
\text { exodus of students the year I left to the } 2 \text { non profit schools in } \\
\text { the city I worked in. SMT were more interested in keeping their } \\
\text { own job than suggesting/ doing anything to improve the } \\
\text { education of students }\end{array}$ & $\begin{array}{l}{ }^{*} \text { Profit } \\
\text { incentive }\end{array}$ \\
\hline No & $\begin{array}{l}\text { Basically my quality life was very low due to the combination } \\
\text { of the answers to Q19. There were not enough suitable outdoor } \\
\text { activities available to me and I was working very long hours } \\
\text { developing resources for my students and the department. }\end{array}$ & WC, PF \\
\hline Yes & $\begin{array}{l}\text { 109. Promotion- Roles within the school were not awarded on } \\
\text { merit, rather to those who liked the Headmaster and were } \\
\text { British. }\end{array}$ & PA \\
\hline Yes & 110. & \\
\hline Yes & 111. Remuneration and teaching load could have been reviewed. & $\begin{array}{l}\text { WC, } \\
\text { Comp }\end{array}$ \\
\hline No & $\begin{array}{l}\text { 112. It was purely a personal decision and since leaving I have } \\
\text { returned to a similar school in China! }\end{array}$ & PF \\
\hline No & $\begin{array}{l}\text { 113. The positive about the previous school is that I could have } \\
\text { chosen to stay there indefinitely (age factored in of course). It } \\
\text { was my choice to leave although the administration would have } \\
\text { liked for me to stay. I fulfilled my contractual obligations. }\end{array}$ & $\overline{P F}$ \\
\hline No & 114. It was not their decision. & $\overline{\mathrm{PF}}$ \\
\hline
\end{tabular}




\begin{tabular}{|c|c|c|}
\hline No & $\begin{array}{l}\text { 115. I would have left even though I liked my administrators } \\
\text { because of living/visa circumstances }\end{array}$ & $\mathrm{HCC}$ \\
\hline Yes & 116. Create a transparent step-based compensation schedule & $\mathrm{AL}$, Comp \\
\hline Yes & If I could remain in __ w/promise not to be relocated to & *Ambig \\
\hline No & $\begin{array}{l}\text { 118. The school I was at needs commitment from staff to say on } \\
\text { more than a year, but the staff needs to be treated with } \\
\text { professionalism and paid accordingly to experience/expertise. }\end{array}$ & $\mathrm{AL}$, Comp \\
\hline No & $\begin{array}{l}\text { 119. In that school } m \text { the local board of governors (all local) } \\
\text { decided to get rid of the expatriates) }\end{array}$ & $\begin{array}{l}\text { *Clear-out } \\
\text { of staff }\end{array}$ \\
\hline No & 120. & \\
\hline No & 121. & \\
\hline No & 122. & \\
\hline No & 123. I was totally happy at the school. & "Ambig \\
\hline Yes & $\begin{array}{l}\text { 124. If I had been allowed to do my job as HoD (Head of } \\
\text { Department) without having the principals change the FL } \\
\text { program according to their own children's needs, it would have } \\
\text { been a wonderful place to work. I felt hindered in trying to build } \\
\text { the program and write the curriculum that was requested of me. }\end{array}$ & $\mathrm{AL}$ \\
\hline Yes & $\begin{array}{l}\text { 125. Dealt with the issues raised in 19. Senior Management did } \\
\text { not trust the professionals that they themselves appointed to } \\
\text { positions within the school and either did not bother to consult or } \\
\text { ignored the results of consultation. }\end{array}$ & $\overline{A L}$ \\
\hline No & 126. & \\
\hline No & 127. & \\
\hline No & A personal choice that the school was understanding of & PF \\
\hline No & $\begin{array}{l}\text { 129. Head pleasant and understanding of personal } \\
\text { circumstances. }\end{array}$ & PF \\
\hline Yes & $\begin{array}{l}\text { 130. Guaranteed the job I applied for and signed for would have } \\
\text { been mine in the second year, and totally pulled in abusive and } \\
\text { totally unqualified head teacher }\end{array}$ & $\begin{array}{l}\text { "Contract } \\
\text { issues, } \mathrm{AL}\end{array}$ \\
\hline Yes & $\begin{array}{l}\text { 131. The school would often choose not to do anything once you } \\
\text { arrive in the host country, despite stating what was offered } \\
\text { during the interview process. }\end{array}$ & "Misrep \\
\hline No & 132. & \\
\hline Yes & 133. Give more support & $\overline{A L}$ \\
\hline No & 134. I was terribly bored with little or no social life in & $\mathrm{PF}$ \\
\hline Yes & $\begin{array}{l}\text { 135. Too many decisions were out of the hands of qualified } \\
\text { teachers or administrators. (i.e. in the hands of the board) }\end{array}$ & $\begin{array}{l}\text { *Board } \\
\text { issues }\end{array}$ \\
\hline Yes & If the administration had quit, died, been sacked. & $\mathrm{AL}$ \\
\hline No & 137. & \\
\hline No & Die was cast after the Asian economic crash. & $\mathrm{HCC}$ \\
\hline No & All senior posts were held by locals a glass ceiling. & $\begin{array}{l}\text { *Contract } \\
\text { issues }\end{array}$ \\
\hline No & $\begin{array}{l}\text { 140. It was an entirely personal reason that I was leaving due to } \\
\text { the living standards more than the school. }\end{array}$ & $\mathrm{PF}$ \\
\hline Yes & $\begin{array}{l}\text { 141. It took } 12 \mathrm{mths} \text { to get a working visa and I didn't like being an } \\
\text { illegal worker during that time. I was not prepared to go through } \\
\text { that situation a second time and didn't trust the principal. }\end{array}$ & $\overline{A L}$ \\
\hline & 142. Response deleted, participant ineligible. & \\
\hline No & $\begin{array}{l}\text { 143. I, among others wanted to leave for the reasons in question } \\
19\end{array}$ & ${ }^{*}$ Ambig \\
\hline
\end{tabular}




\begin{tabular}{|c|c|c|}
\hline Yes & 144. Senior positions within the school were condensed & ${ }^{*}$ Ambig \\
\hline Yes & Improved communication with management and support & $\mathrm{AL}$ \\
\hline No & 146. & \\
\hline No & 147. & \\
\hline Yes & $\begin{array}{l}\text { 148. They could have increased the salary to bring us up to par } \\
\text { with better international schools elsewhere; there had been no } \\
\text { significant salary rise in over } 5 \text { years and yet the cost of living in } \\
\text { had doubled in that time. They could have improved the } \\
\text { contract package by including: pension plan, better health } \\
\text { insurance, yearly flights instead of every } 2 \text { years, service } \\
\text { gratuity, shipping, professional development allowance, and } \\
\text { post of responsibility allowances. }\end{array}$ & Comp \\
\hline Yes & $\begin{array}{l}\text { 149. Could have pressured the school commission to provide } \\
\text { compensation for the cost of housing }\end{array}$ & Comp \\
\hline No & 150. My reason for leaving was personal (family). & $\mathrm{PF}$ \\
\hline Yes & $\begin{array}{l}\text { 151. I was taken on as a Spanish teacher with French. The } \\
\text { school at that stage only taught Spanish at DP but I was } \\
\text { informed that I was being recruited to introduce Spanish at MYP. } \\
\text { This never happened and I was not informed beforehand of this } \\
\text { and hence given a chance to reconsider my position. I would not } \\
\text { have gone there had I been informed and my timetable was } \\
\text { withheld until I had arrived until induction, them saying that it } \\
\text { had not been completed but it had. I was also recruited on a } \\
\text { lower pay scale which was school policy since the previous } \\
\text { summer but I was not informed of this. Again I would not have } \\
\text { gone there if the admin had informed me of this. The new admin } \\
\text { could have rectified this latter point. I also was open with the } \\
\text { principal and said that I was considering leaving as the school } \\
\text { had not honored contractual obligations. I was going to do a } \\
\text { TEFL course. His response was to say that if I stayed I could } \\
\text { teach EFL the next year as there was going to be a vacancy but } \\
\text { he went back on his word. }\end{array}$ & $\begin{array}{l}{ }^{*} \text { Misrep, } \\
\text { AL }\end{array}$ \\
\hline Yes & $\begin{array}{l}\text { 152. I offered to stay on if they would let my children attend for } \\
\text { free. I spent half my salary on their tuition! }\end{array}$ & Comp \\
\hline No & $\begin{array}{l}\text { 153. I answered no because my mind was set to leave. However, } \\
\text { If contractual conditions would have been EXTREMELY } \\
\text { profitable I would probably have stayed a couple more years. }\end{array}$ & Comp \\
\hline Yes & $\begin{array}{l}\text { 154. Perhaps a more transparent, positive learning environment } \\
\text { and a collaborative and systematic approach to school change } \\
\text { would have given me a reason to stay. A more knowledgeable } \\
\text { and balanced administrative structure with IBPYP experience } \\
\text { would have helped or willingness to promote those with training } \\
\text { and experience (the Head had no international education } \\
\text { experience and no IB experience). The compensation package } \\
\text { was extremely poor and devaluing. }\end{array}$ & AL, Comp \\
\hline No & 155. They were the reason behind the decision. & $\mathrm{AL}$ \\
\hline No & 156. & \\
\hline No & 157. & \\
\hline No & $\begin{array}{l}\text { 158. I was ready to move on. As a single person my personal } \\
\text { environment was very important to me as it made up my support } \\
\text { network (family). Maybe this is the same for families that live } \\
\text { overseas. Aside from having felt like I had explored the country } \\
\text { and region at length, I also felt ready to make some new } \\
\text { international friends as the friends I had been with were great, }\end{array}$ & PF \\
\hline
\end{tabular}




\begin{tabular}{|c|c|c|}
\hline & but also moving on. & \\
\hline No & $\begin{array}{l}\text { 159. The decision to leave was entirely our own and more to do } \\
\text { with wanting to change countries than any thing else. }\end{array}$ & PF \\
\hline Yes & $\begin{array}{l}\text { 160. Institutionally to have provided a real framework which } \\
\text { promoted and established work and life balance as a core value }\end{array}$ & ${ }^{*}$ Ambig \\
\hline No & $\begin{array}{l}\text { 161. Had lived in Asia for } 5 \text { years, felt I needed a return to } \\
\text { Europe to both re-establish my credentials as a professional } \\
\text { teacher and to develop a personal life }\end{array}$ & $P F$ \\
\hline Yes & Supported the art department & AL \\
\hline Yes & $\begin{array}{l}\text { 163. Realize the time and effort I had put into the school for } 6 \\
\text { years. Show respect for my position and for what I had done. }\end{array}$ & $A L$ \\
\hline No & $\begin{array}{l}\text { 164. The school, principal and administration, were very } \\
\text { understanding of our predicament and did all they could to make } \\
\text { the transition to the US as smooth as possible. Kudos to them! }\end{array}$ & $\mathrm{PF}$ \\
\hline Yes & $\begin{array}{l}\text { 165. Management could have been more proactive in using my } \\
\text { skills rather than seeking to control through a small group. Also } \\
\text { could have been more organized about school needs for next } \\
\text { year earlier so that I was informed about opportunities in a } \\
\text { timely manner. }\end{array}$ & $\mathrm{AL}$ \\
\hline Yes & $\begin{array}{l}\text { 166. Appreciation, be open to ideas, be honest and ethical, not } \\
\text { treat school like a business }\end{array}$ & $\begin{array}{l}\text { *Profit } \\
\text { incentive, } \\
\mathrm{AL}\end{array}$ \\
\hline No & 167. & \\
\hline Yes & $\begin{array}{l}\text { 168. They could allow official personal days to give teachers a } \\
\text { chance to escape the city! In 1995-97, International School } \\
\text { had } 4 \text { months straight of school with only one long weekend. In } \\
\text { a polluted, demanding environment, where it is virtually } \\
\text { impossible or absolutely exhausting to get out for a two-day } \\
\text { weekend, teachers needed a break, so we were told to } \\
\text { "unofficially" take sick days if we needed to get away. I would } \\
\text { have strongly preferred a better calendar (which the school now } \\
\text { has!) and two personal days which could be used flexibly during } \\
\text { the year to prevent burn-out. }\end{array}$ & $\begin{array}{l}{ }^{*} \text { Contract } \\
\text { issues }\end{array}$ \\
\hline No & $\begin{array}{l}\text { 169. The long running union battle for parity of pay would not be } \\
\text { resolved quickly. The city of _ was a little claustrophobic. }\end{array}$ & $\begin{array}{l}\text { Comp, } \\
\text { HCC }\end{array}$ \\
\hline Yes & $\begin{array}{l}\text { 170. Promoted posts were offered to new sometimes less } \\
\text { experienced teachers to get them to come on board (meaning } \\
\text { loss of my A level timetable iast year) and Head of Depts. } \\
\text { position not offered internally. Promotion would certainly have } \\
\text { made me consider staying. }\end{array}$ & $\mathrm{AL}$ \\
\hline Yes & $\begin{array}{l}\text { 171. The board of governors becoming an elected body and the } \\
\text { resignation of the entire SMT would have been the only } \\
\text { conditions under which I would have stayed }\end{array}$ & $\overline{A L}$ \\
\hline Yes & $\begin{array}{l}\text { 172. The administration never showed any interest in keeping } \\
\text { staff members. In their view teachers are a dime a dozen and } \\
\text { can be replaced easily. No effort was made to find out how } \\
\text { teachers were doing or what could be done to keep teachers. }\end{array}$ & $\overline{A L}$ \\
\hline Yes & $\begin{array}{l}\text { 173. Proper training; a proficient head of department (my HoD } \\
\text { was the Head of English and had therefore no experience of } \\
\text { MFL leadership); more freedom as an individual - teachers were } \\
\text { bound to certain social rules as it was a small place where } \\
\text { everyone knew us }\end{array}$ & $A L, P F$ \\
\hline No & $\begin{array}{l}\text { 174. It was the time of life for us... the world was too big to sit still } \\
\text { for too long. Our director was quite difficult to work with, as well, }\end{array}$ & $\overline{P F}$ \\
\hline
\end{tabular}




\begin{tabular}{|c|c|c|}
\hline & but our main reason was to get on to another part of the world. & \\
\hline Yes & Providing more support for the teachers. & $\mathrm{AL}$ \\
\hline Yes & $\begin{array}{l}\text { 176. More support of the teachers, they treated us like we were } \\
\text { very disposable }\end{array}$ & $\overline{\mathrm{AL}}$ \\
\hline Yes & $\begin{array}{l}\text { 177. More respect from the management, teachers were left } \\
\text { uninformed about many issues that were relevant to them, } \\
\text { dictatorial management. }\end{array}$ & $\overline{\mathrm{AL}}$ \\
\hline No & $\begin{array}{l}\text { Why waste } 2 \text { years of my life working in a non-supportive } \\
\text { environment for very poor professional or financial reward. }\end{array}$ & $\mathrm{AL}, \mathrm{Comp}$ \\
\hline No & $\begin{array}{l}\text { 179. Due to the head teacher being in charge of everything the } \\
\text { school was literally under their control in all ways. Also, the } \\
\text { school was run in a totalitarian manner without democratic } \\
\text { decision making involving staff. }\end{array}$ & $\overline{A L}$ \\
\hline No & 180. & \\
\hline No & It was too bad to correct in any reasonable time-frame. & *Ambig \\
\hline No & $\begin{array}{l}\text { Not really. I didn't want to stay in country any longer. } \\
\text { Although in the year I left they did without warning alter all future } \\
\text { contracts to mandate a portion of pay into local currency. If I } \\
\text { hadn't already decided to leave, this would have forced my } \\
\text { decision to leave. }\end{array}$ & $\begin{array}{l}{ }^{*} \text { Contract } \\
\text { issues, } \mathrm{PF}\end{array}$ \\
\hline No & $\begin{array}{l}\text { 183. They could not affect the levels of pollution or the lack of } \\
\text { cultural events and my immediate supervisor was very efficient } \\
\text { but sometimes overbearing. In the past I was the manager of the } \\
\text { library and this time I was under the authority of a Head } \\
\text { Librarian. We had differences of opinion but he was my superior. }\end{array}$ & $\begin{array}{l}\text { *Conflict } \\
\text { with } \\
\text { admin, } \\
\text { HCC }\end{array}$ \\
\hline Yes & $\begin{array}{l}\text { 184. Listened. Acknowledged my concerns. Been honest. Valued } \\
\text { my contribution. }\end{array}$ & $\overline{A L}$ \\
\hline Yes & $\begin{array}{l}\text { 185. Create a possible workload higher than } 40 \text { percent } \\
\text { temporarily by adding a class and/or other duties take seniority } \\
\text { into consideration }\end{array}$ & ${ }^{*}$ Ambig \\
\hline Yes & 186. & \\
\hline Yes & $\begin{array}{l}\text { 187. Not driven its middle managers so hard been more open in } \\
\text { its communication with teachers }\end{array}$ & $\mathrm{AL}$ \\
\hline Yes & $\begin{array}{l}\text { 188. I would have liked to teach Music at the Middle School level } \\
\text { as well as Spanish and French at those same levels. }\end{array}$ & $\overline{W C}$ \\
\hline Yes & $\begin{array}{l}\text { 189. They could have supported the teachers that they wanted to } \\
\text { stay by talking to the board. }\end{array}$ & $\overline{A L}$ \\
\hline No & $\begin{array}{l}\text { 190. My decision to remain after the temporary contract was a } \\
\text { mistake and I left at the earliest opportunity (after a full } \\
\text { academic year). }\end{array}$ & *Ambig \\
\hline No & $\begin{array}{l}\text { 191. I don't think so as at the time I wanted to return to teaching } \\
\text { in special education as I had enjoyed it more than the learning } \\
\text { support job in the international school. }\end{array}$ & $\overline{P A}$ \\
\hline No & $\begin{array}{l}\text { 192. Probably not, although fixing the problem of uneven } \\
\text { workloads and taking definitive action on some of the other } \\
\text { problems might have prevented me from feeling I was in a rut. }\end{array}$ & $\mathrm{AL}$ \\
\hline No & $\begin{array}{l}\text { 193. The school's admin was very supportive, } 1 \text { liked them. I } \\
\text { found one or two parents less than supportive which added to } \\
\text { my emotional load at the time. }\end{array}$ & WC \\
\hline No & 194. See answer to question 19 & "Ambig \\
\hline No & I was lucky to have escaped. & "Ambig \\
\hline No & It was a personal choice. & $\mathrm{PF}$ \\
\hline Yes & 197. & \\
\hline
\end{tabular}




\begin{tabular}{|c|c|c|}
\hline Yes & $\begin{array}{l}\text { Increase my salary substantially Increase the value of the } \\
\text { package Upgrade teacher housing }\end{array}$ & Comp \\
\hline Yes & $\begin{array}{l}\text { 199. The situation is too complicated to explain here, but in } \\
\text { nutshell the Director was inexperienced and only tried to retain } \\
\text { the staff that were leaving once she found out that she was } \\
\text { unable to recruit equivalent replacements to the staff she had } \\
\text { lost. }\end{array}$ & $\overline{A L}$ \\
\hline Yes & $\begin{array}{l}\text { 200. The management were appointed by the owners of the } \\
\text { school. Priority } 1 \text { was the } 1.3 \text { million US that was required to pay } \\
\text { the rent!! The "management" then appointed a new director \& } \\
\text { sacked him in Aug with no explanation to staff. "Management" } \\
\text { did not offer any support to injured staff members as that was } \\
\text { the role of the director. }\end{array}$ & $\begin{array}{l}\text { "Private } \\
\text { ownership }\end{array}$ \\
\hline Yes & 201. Increase compensation package & Comp \\
\hline Yes & $\begin{array}{l}\text { 202. Transparency in school direction. Participation in school } \\
\text { direction. Integrity with salary. }\end{array}$ & $\overline{A L}$ \\
\hline No & $\begin{array}{l}\text { Because they had not been honest about the role and the } \\
\text { circumstances of the school; my position was made untenable } \\
\text { because it was split between different sections, public and } \\
\text { private, different campuses and different managements, French } \\
\text { and Anglophone. }\end{array}$ & ${ }^{*}$ Misrep \\
\hline Yes & 204. Value good motivated teachers & $\overline{A L}$ \\
\hline Yes & They could have increased my pay scale. & Comp \\
\hline Yes & $\begin{array}{l}\text { Management contributed largely to make me feel undesired } \\
\text { and did not offer the support expected from an employer who } \\
\text { truly intends to honor the original contract. It became obvious } \\
\text { that I had never corresponded to the profile desired by the } \\
\text { school although I had much to offer by way of experience both in } \\
\text { the teaching of my subject and my understanding of } \\
\text { internationalism in education. The excellent references and } \\
\text { recommendations from my previous school only served to } \\
\text { ensure that I would do a thorough and serious work of my } \\
\text { teaching assignment until someone with the desired profile } \\
\text { would come along and replace the person who had left just } \\
\text { before me- both belonging to the same stereotype as far as age, } \\
\text { gender and nationality went. This process has happened } \\
\text { sufficiently often in the past to have become identified among } \\
\text { the remaining staff as a well established procedure from } \\
\text { management. }\end{array}$ & $\begin{array}{l}\text { *Misrep, } \\
\mathrm{AL}\end{array}$ \\
\hline Yes & $\begin{array}{l}\text { 207. I was teaching kindergarten- now I am a head of English } \\
\text { teaching } 13 \text { year olds, successfully. I am not cut out for } \\
\text { kindergarten work, was bored and frustrated. I was not allowed } \\
\text { to swap classes, despite someone who was kg trained wanting } \\
\text { to swap with me. }\end{array}$ & $\mathrm{AL}$ \\
\hline Yes & $\begin{array}{l}\text { 208. Been more supportive of teaching staff and a more } \\
\text { transparent system of communication. }\end{array}$ & $\overline{\mathrm{AL}}$ \\
\hline Yes & $\begin{array}{l}\text { The school's Director has just been asked to step down and } \\
\text { will now be head of the senior school only, this may easy some } \\
\text { of the problems between staff and the } \\
\text { administration/management but I had aiready decided to leave } \\
\text { and had been accepted as a student for a postgraduate course } \\
\text { in September. }\end{array}$ & $\overline{A L}, \overline{P A}$ \\
\hline No & $\begin{array}{l}\text { 210. There were no changes being made in the school ethos. I } \\
\text { was offered more money, but the conditions at school (poor } \\
\text { management, low staff morale) were not going to change. }\end{array}$ & $\overline{A L}$ \\
\hline
\end{tabular}




\begin{tabular}{|c|c|c|}
\hline No & Financial and personal circumstances motivated the move. & $\mathrm{PF}$ \\
\hline No & $\begin{array}{l}\text { 212. We had already decided to leave regardless of any offers } \\
\text { made. }\end{array}$ & ${ }^{\star A}$ Ambig \\
\hline Yes & $\begin{array}{l}\text { 213. There was no appreciation for the work done. No } \\
\text { compensation ever, no new contract proposed to teachers who } \\
\text { have been there for many years. }\end{array}$ & $\mathrm{AL}$ \\
\hline Yes & $\begin{array}{l}\text { 214. They could have honored the amount I was offered (in } \\
\text { writing) during the hiring process, instead of reducing the } \\
\text { amount by } \$ 8000 \text { USD after I was already in country. They } \\
\text { could have supported their teachers instead of establishing an } \\
\text { "us" vs. "them" mentality with the business office that was run by } \\
\text { the publishing company that owned the school. The director } \\
\text { could have opened lines of communication when the staff } \\
\text { expressed concern over practices, decisions, and quality of } \\
\text { educational program instead of threatening them. The principal } \\
\text { and director could have been teacher advocates with the owner } \\
\text { rather than playing both sides, thereby instilling distrust amongst } \\
\text { the staff. }\end{array}$ & $\begin{array}{l}\text { *Misrep, } \\
\text { AL }\end{array}$ \\
\hline No & 215. & \\
\hline No & $\begin{array}{l}\text { 216. Both the Headmaster and Senior High Principal were poor } \\
\text { leaders. They had little or no effect on the owner of the school } \\
\text { and the increasing lack of discipline. }\end{array}$ & $\mathrm{AL}$ \\
\hline Yes & 217. Told the truth about taxes for expats and salary & ${ }^{*}$ Misrep \\
\hline Yes & Listened and displayed more transparency & $\mathrm{AL}$ \\
\hline Yes & $\begin{array}{l}\text { 219. There seem to be "arrangements" made by the Headmaster } \\
\text { with some staff if the school wants to keep people }\end{array}$ & $\mathrm{AL}$ \\
\hline Yes & $\begin{array}{l}\text { 220. Not cutting class time with IB students and claiming it was } \\
\text { for their benefit. Fair salary scale that was irrespective of what } \\
\text { age or subject you taught. }\end{array}$ & $\overline{\mathrm{AL}}$ \\
\hline$\frac{\text { No }}{\text { Yoc }}$ & $\begin{array}{l}\text { 221. The school administration did not have the power to change } \\
\text { the culture of the school. }\end{array}$ & "Ambig \\
\hline Yes & I would have stayed if they were able to be honest & *Ambig \\
\hline Yes & $\begin{array}{l}\text { 223. Contracts should be issued with full salary and conditions } \\
\text { within a time period long enough for staff to decide whether they } \\
\text { are prepared to accept these conditions or go to a job fair. }\end{array}$ & $\mathrm{AL}$ \\
\hline No & $\begin{array}{l}\text { 224. Short of building a performing arts centre, nothing was going } \\
\text { to change my mind. }\end{array}$ & WC \\
\hline & 225. Response deleted, participant ineligible. & \\
\hline Yes & $\begin{array}{l}\text { 226. The senior management could have valued the role of } \\
\text { Upper School Resource Teacher more from the start. My job } \\
\text { description should have been clarified. Was I a school } \\
\text { psychologist or a learning support teacher? In the end I left } \\
\text { because I did not feel that my professional knowledge or } \\
\text { expertise was valued by the administration. }\end{array}$ & $\overline{A L}$ \\
\hline Yes & 227. Only by offering a higher salary & Comp \\
\hline Yes & $\begin{array}{l}\text { 228. They could have been honest with incoming teachers about } \\
\text { workload, pay, expectations, etc }\end{array}$ & $\mathrm{AL}$ \\
\hline Yes & $\begin{array}{l}\text { 229. Providing help with rent/housing, raising teacher salaries, } \\
\text { anything to allow teachers to live in w without going into } \\
\text { debt }\end{array}$ & Comp \\
\hline Yes & $\begin{array}{l}\text { 230. Two programmes (IB and IGCSE) didn't fit, IB-Physics was } \\
\text { not in the list of priorities of the school, so in the long run, I } \\
\text { would have never been able to teach it }\end{array}$ & $\mathrm{PF}$ \\
\hline Yes & I was hired as an expert in my field, so the admin needed to & $\overline{A L}$ \\
\hline
\end{tabular}




\begin{tabular}{|c|c|c|}
\hline & $\begin{array}{l}\text { listen to what the research said about learning. There was no } \\
\text { plan to effect change. little use of effective communication } \\
\text { strategies }\end{array}$ & \\
\hline Yes & $\begin{array}{l}\text { 232. If the school had attempted to lessen the number of preps } \\
\text { expected of teachers or had attempted to give teachers their } \\
\text { own classrooms, I might not have left. }\end{array}$ & WC \\
\hline Yes & $\begin{array}{l}\text { 233. Management could have listened to why teachers chose to } \\
\text { leave the school and addressed these issues, rather than } \\
\text { ignoring them. }\end{array}$ & $\overline{\mathrm{AL}}$ \\
\hline Yes & $\begin{array}{l}\text { 234. Listened to my advice and that of other experienced } \\
\text { teachers }\end{array}$ & $\mathrm{AL}$ \\
\hline Yes & $\begin{array}{l}\text { 235. If the administration had been more proactive and willing to } \\
\text { stand up to students and their parents and support teachers, it } \\
\text { would have been a completely different situation. }\end{array}$ & $\begin{array}{l}\text { WC, SD, } \\
\mathrm{AL}\end{array}$ \\
\hline No & $\begin{array}{l}\text { 236. Felt trapped in the school and the country. Very unsafe to } \\
\text { travel in country or even to and from store!! Did not like living } \\
\text { behind bars. People generally unfriendly in the country. }\end{array}$ & $\mathrm{HCC}$ \\
\hline No & $\begin{array}{l}\text { 237. It was far too late for that and I felt that the entire } \\
\text { administration had to leave before any remedy could begin. }\end{array}$ & $\mathrm{AL}$ \\
\hline No & 238. See 19 & *Ambig \\
\hline Yes & $\begin{array}{l}\text { 239. If I was permitted to advance my professional skills. I was } \\
\text { not given permission to go on any professional development } \\
\text { courses, as she didn't feel there were sufficient funds within the } \\
\text { school to support me, as she would not be hiring me in the } \\
\text { following academic year. }\end{array}$ & PA \\
\hline Yes & $\begin{array}{l}\text { 240. Perhaps! Annual home leave could have helped us to stay } \\
\text { connected with family/friends in Canada. It's hard to say though } \\
\text { if that would have been enough to sway our decision. Perhaps if } \\
\text { we had been granted an extension on our leave, it would have } \\
\text { been enough. }\end{array}$ & $\begin{array}{l}{ }^{*} \text { Contract } \\
\text { issues }\end{array}$ \\
\hline No & 241. & \\
\hline Yes & $\begin{array}{l}\text { 242. My living quarters were not what was promised or } \\
\text { reasonable for a professional teacher }\end{array}$ & "Misrep \\
\hline Yes & 243. They could insist for my permission & "Ambig \\
\hline Yes & $\begin{array}{l}\text { 244. Be more honest, fair with all staff, not changing work } \\
\text { conditions, pay and equal working conditions, help with } \\
\text { language lessons and paperwork ie visas and translations, } \\
\text { communicate and recognize teachers ideas and experiences } \\
\text { support, support, support }\end{array}$ & $\mathrm{AL}$ \\
\hline Yes & $\begin{array}{l}\text { 245. Offered Leave of Absence - I applied but my application was } \\
\text { rejected }\end{array}$ & $\begin{array}{l}{ }^{*} \text { Contract } \\
\text { issues }\end{array}$ \\
\hline No & $\begin{array}{l}\text { 246. This was a joint decision made by both my spouse and I. It } \\
\text { was in the best interest for us socially, mentally, and spiritually. }\end{array}$ & $\overline{\mathrm{PF}}$ \\
\hline No & 247. & \\
\hline Yes & $\begin{array}{l}\text { 248. Administration could have been more organized and } \\
\text { communicated better with teachers. The induction program was } \\
\text { poor and got the year off to a poor start. The support was poor } \\
\text { through out the entire year. The school had a lot of potential and } \\
\text { great students and teachers but the administration didn't seem } \\
\text { to realize it or value their human resources. }\end{array}$ & $\mathrm{AL}$ \\
\hline Yes & 249. Offer more money & Comp \\
\hline Yes & Replace the Head teacher. & $\begin{array}{l}{ }^{*} \text { Conflict } \\
\text { with admin }\end{array}$ \\
\hline No & The honest answer is 'No' as I had made my decision. & $\mathrm{AL}$ \\
\hline
\end{tabular}




\begin{tabular}{|c|c|c|}
\hline & $\begin{array}{l}\text { Perhaps if my immediate line managers had had a more } \\
\text { coherent vision for the direction of the counseling department in } \\
\text { the senior school and were able to work better together, it may } \\
\text { have made a difference. I was asked to stay and, had I been } \\
\text { younger, I may have done so. However, as a mature person } \\
\text { with many years experience in international schools, I was at the } \\
\text { stage where I preferred to be at ease with myself, my school } \\
\text { and my living environment. }\end{array}$ & \\
\hline Yes & $\begin{array}{l}\text { 252. The admin want a staff of yes-men and won't accept } \\
\text { constructive suggestions even when they ask for them. They } \\
\text { blame staff reps personally for any grievances they are asked to } \\
\text { raise on behalf of others and then are happy to promote hate } \\
\text { campaigns against individual teachers. They tried to destroy me } \\
\text { professionally. Luckily I have years of references stored at CIS, } \\
\text { so I walked into another job and have had my professional } \\
\text { confidence in myself restored. }\end{array}$ & $\mathrm{AL}$ \\
\hline Yes & $\begin{array}{l}\text { 253. Treated the staff professionally Expressed value in staff } \\
\text { Provided much better living accommodation }\end{array}$ & $\begin{array}{l}\text { *Contract } \\
\text { issues, AL }\end{array}$ \\
\hline Yes & 254. Better remuneration in terms of salary and other benefits. & Comp \\
\hline Yes & The board could have gotten rid of the superintendent. & $\begin{array}{l}\text { *Conflict } \\
\text { with admin }\end{array}$ \\
\hline Yes & $\begin{array}{l}\text { 256. They didn't have to tell me to leave. A little support would } \\
\text { have helped. Another teacher had told me prior to this I was } \\
\text { being set up, but I had no idea. }\end{array}$ & $\mathrm{AL}$ \\
\hline No & $\begin{array}{l}257 . \quad \text { See C above ... although I was basically happy and was } \\
\text { leaving more because of a desire to return to UK. I think I would } \\
\text { have felt more confident about leaving the programme had } 2 \text { (or } \\
1.5 \text { teachers) been hired to replace me - but I still would have } \\
\text { left for positive personal reasons. I was not particularly surprised } \\
\text { however when my replacement only stayed a single year citing } \\
\text { workload. Now staffing levels in the department have been } \\
\text { increased and are stable. Turnover at the school is, I feel, } \\
\text { reasonable. }\end{array}$ & $\mathrm{PF}$ \\
\hline No & 258. & \\
\hline No & $\begin{array}{l}\text { 259. Potential university students must have lived in EU for } 3 \\
\text { consecutive years before going to university to benefit from } \\
\text { paying local EU fees. }\end{array}$ & ${ }^{*}$ Ambig \\
\hline Yes & $\begin{array}{l}\text { 260. Value family living arrangements further: hectic work } \\
\text { schedule left little time for us to pursue our own interests. }\end{array}$ & WC \\
\hline No & $\begin{array}{l}\text { 261. As mentioned in 18, all staff bar one have left the school } \\
\text { since February 2006, many of which have left before their } \\
\text { contracts ended, thus forfeiting a bonus for completing their } \\
\text { contract as required by law. After all the mismanagement, } \\
\text { deceit and additional costs incurred personally for professional } \\
\text { development I decided it was best to leave the school at the end } \\
\text { of my contract and seek employment elsewhere. }\end{array}$ & $\overline{A L}$ \\
\hline No & $\begin{array}{l}\text { 262. No because I was always going to leave due to my passion } \\
\text { for traveling as well. Teaching and traveling go hand in hand for } \\
\text { me to increase my skills as a teacher and educator. }\end{array}$ & PF \\
\hline No & $\begin{array}{l}\text { 263. Although much could have been done to reduce the } \\
\text { frustrations of the job, (same frustrations are experienced by } \\
\text { most staff) the mismatch between package and workload would } \\
\text { still have resulted in the decision to leave }\end{array}$ & WC \\
\hline No & $\begin{array}{l}\text { 264. Difficulties with family in UK was the main reason for } \\
\text { leaving. }\end{array}$ & $\mathrm{PF}$ \\
\hline
\end{tabular}




\begin{tabular}{|c|c|c|}
\hline No & $\begin{array}{l}\text { 265. I was asked to stay but for the reasons outlined above } \\
\text { decided not to. }\end{array}$ & Ambig \\
\hline Yes & $\begin{array}{l}\text { 266. Fired the head of school as he was universally despised by } \\
\text { the staff. No one respected him as he thought we worked for } \\
\text { him not with him. He had no understanding of the necessity for } \\
\text { everyone to feel part of a team working towards the same goal }\end{array}$ & $\overline{A L}$ \\
\hline No & 267. School couldn't change in order to accommodate me & $\mathrm{PF}$ \\
\hline Yes & $\begin{array}{l}\text { 268. Lessen workload, more teacher involvement in decision } \\
\text { making, slow down pace of change }\end{array}$ & WC, AL \\
\hline Yes & $\begin{array}{l}\text { 269. They did provide a temporary job for my husband but this } \\
\text { was not enough. }\end{array}$ & $\begin{array}{l}\text { "Contract } \\
\text { issues }\end{array}$ \\
\hline & 270. Response deleted, participant ineligible & \\
\hline Yes & $\begin{array}{l}\text { 271. They could have been more supportive of teachers instead } \\
\text { of protecting management's interests. Their assertions that they } \\
\text { respect teachers as professionals were not upheld in reality. }\end{array}$ & $\overline{A L}$ \\
\hline Yes & $\begin{array}{l}\text { 272. They could have shown more interest in the work I had done } \\
\text { for the school. Even though I was part-time I put in a lot and } \\
\text { work hard for the school. }\end{array}$ & $\overline{\mathrm{AL}}$ \\
\hline Yes & They could have resigned & $\begin{array}{l}\text { "Conflict } \\
\text { with admin }\end{array}$ \\
\hline No & 274. & \\
\hline Yes & I'm out of time... & ${ }^{\star}$ Ambig \\
\hline No & $\begin{array}{l}\text { 276. Pay was only enough to just live on and with my father ill in } \\
\text { Australia I wanted to move somewhere closer so that I could } \\
\text { afford to visit him more regularly. }\end{array}$ & Comp, PF \\
\hline Yes & $\begin{array}{l}\text { 277. Have the principal and senior admin resign! Or completely } \\
\text { change the way they ran the school and treated their staff... but } \\
\text { that's probably asking a bit much from these kind of people. }\end{array}$ & $\mathrm{AL}$ \\
\hline Yes & $\begin{array}{l}\text { 278. Follow through on their verbal promise that I would be } \\
\text { placed in the Special Ed dept as soon as possible. I did } 3 \text { years } \\
\text { in grade } 2 \text { with no movement into special education possible. } \\
\text { They could have put } 2 \text { local hire jobs together when personnel } \\
\text { left to give me a position, especially as I am qualified for that } \\
\text { age } 3 \text { through } 17 \text {. They would not provide the money for an } \\
\text { overseas hire position and I also think I was a victim of my own } \\
\text { success in grade } 2 \text {. They also lost my husband who was } \\
\text { another very successful teacher at the school. Both if us were } \\
\text { ranked top } 2 \text { percentile of teachers worldwide ranked as } \\
\text { veterans even then (1990). }\end{array}$ & ${ }^{\star}$ Misrep \\
\hline No & $\begin{array}{l}\text { 279. We had made a decision to leave and were therefore } \\
\text { committed to leaving. }\end{array}$ & $\overline{\mathrm{PF}}$ \\
\hline Yes & 280. & \\
\hline Yes & $\begin{array}{l}\text { 281. They could have honored their commitment and promise of } \\
\text { professional development. They could have honored my desire } \\
\text { to move into IB teaching when all of the IB teachers were } \\
\text { leaving the school. }\end{array}$ & ${ }^{\star}$ Misrep \\
\hline No & 282. Family comes first & $\mathrm{PF}$ \\
\hline No & $\begin{array}{l}\text { 283. Our decision had nothing to do with the school itself, in fact } \\
\text { we were very happy there. }\end{array}$ & *Ambig \\
\hline No & $\begin{array}{l}\text { 284. My partner and I were determined we wanted to leave and } \\
\text { go somewhere else. }\end{array}$ & $\mathrm{PF}$ \\
\hline No & 285. They respected my decision and supported me in it. & *Ambig \\
\hline Yes & $\begin{array}{l}\text { 286. Replace corrupt leadership with humane educators. Lived } \\
\text { up to salary expectations and stopped favoritism. }\end{array}$ & AL, Comp \\
\hline
\end{tabular}


Question 22: "Do you have any further comments regarding your departure from this school?"

\begin{tabular}{l|l}
\hline Respondent Number and written response & $\begin{array}{l}\text { Causal Factor } \\
\text { Categories }\end{array}$ \\
\hline 2. I was grateful to the school for providing me with the first opportunity to teach \\
overseas, and for the experience in teaching subjects with which I was unfamiliar at \\
the time. This enabled me to find employment with other international schools.
\end{tabular}




\begin{tabular}{|c|c|}
\hline $\begin{array}{l}\text { hard working department with a heavy workload of marking this was in the end } \\
\text { making me too angry. }\end{array}$ & \\
\hline $\begin{array}{l}\text { 17. I would have loved to stay there, should there have been possibilities for } \\
\text { leadership in the very near future. }\end{array}$ & PA \\
\hline $\begin{array}{l}\text { 18. It was very sad to leave the country and the community of families at the school } \\
\text { but the leadership situation made it impossible to stay. }\end{array}$ & $\mathrm{AL}$ \\
\hline $\begin{array}{l}\text { 20. } \frac{\text { school politics is not transparent. Local clients expectations different }}{\text { from expat. Decline in dollar linked to }} \text { means quality staff harder to attract }\end{array}$ & $\mathrm{HCC}, \mathrm{WC}$ \\
\hline $\begin{array}{l}\text { 21. They have to ensure salary is in line with the cost of living in that particular } \\
\text { area. Also arrange accommodation prior to the staff's arrival, fumigated before } \\
\text { hand. I was placed in a grotty hotel for almost } 2 \text { weeks before I was housed in an } \\
\text { un-fumigated property. I also felt that the staff there were quite unprofessional in } \\
\text { their behavior, constantly backbiting and involving themselves in other people's } \\
\text { private affairs; something that I managed to avoid whilst working in the UK. The } \\
\text { school itself was under-resourced and the administrative staff were not managed } \\
\text { well. It was a valuable experience, and quite possibly I would have stayed if I had } \\
\text { some family nearby so that it wasn't so lonely when I came home from school. }\end{array}$ & $\begin{array}{l}\text { * Colleagues, } \\
\text { Comp, AL, PF }\end{array}$ \\
\hline 22. Would like to go back for another contract at some stage & *Supplementary \\
\hline $\begin{array}{l}\text { 23. Schools spend a lot of money searching for and recruiting faculty. They need to } \\
\text { ensure that they hire the right person for the job. The school knew my educational } \\
\text { background, my experience and my personal qualities. I think there is a lot of } \\
\text { damage done when schools don't invest themselves enough in the search process } \\
\text { and truly get the right person for the job. I have really high expectations of schools, } \\
\text { administration, teachers and students and I want the school to be as it portrays } \\
\text { itself. Otherwise, it's a waste of time working there and no one is happy. I wanted to } \\
\text { leave my NEXT school at the end of my first contract because the school didn't end } \\
\text { up being what it was portrayed to be. Also a proprietary school, decisions were } \\
\text { made that were not in the best interests of the students and their education. I will } \\
\text { now no longer consider working at proprietary schools and will only work for non- } \\
\text { profit schools, where I am much happier. }\end{array}$ & $\begin{array}{l}\text { *Misrep, Profit } \\
\text { incentive }\end{array}$ \\
\hline $\begin{array}{l}\text { 24. We loved the school. It was a progressive, risk taking school. But we couldn't } \\
\text { afford to continue using our retirement savings to live. }\end{array}$ & Comp \\
\hline $\begin{array}{l}\text { 29. It is a shame the school is going down hill, there have been numerous Heads in } \\
\text { a very short period of time. The Head recruited from from a failing school } \\
\text { where he had pulled it up to standard only lasted } 2 \text { years - he left the year after I } \\
\text { left. A bit of stability for an excellent school would have been a lot better than } \\
\text { constantly trying to replace Heads and Staff. }\end{array}$ & ${ }^{*}$ High turnover \\
\hline $\begin{array}{l}\text { 32. I continued to teach overseas and the next school offered everything outlined in } \\
\text { \#19. The influence and support of the Board of Trustees is also a crucial factor in } \\
\text { retaining teachers. }\end{array}$ & *Board influence \\
\hline 35. Poor decisions by Management. No discussion / input from staff available & $\mathrm{AL}$ \\
\hline $\begin{array}{l}\text { 36. In general, it was a school with many excellent qualities, suitable for just } \\
\text { starting or just finishing/retiring, but not for the long term. }\end{array}$ & *Supplementary \\
\hline $\begin{array}{l}\text { 38. I am now in a far better school in the same city, making far better money with } \\
\text { an administration who is knowledgeable, professional and kind. }\end{array}$ & AL, Comp \\
\hline $\begin{array}{l}\text { 42. The atmosphere at the school was great. The physical location was } \\
\text { spectacular, overlooking the hills, just } 100 \text { meters from } \\
\text { moved to _ now that was a mistake. One cannot move from the beauty and } \\
\text { sophistication of to the heat and third-world grubbiness of ___ but that's } \\
\text { another story! Good luck with your study. }\end{array}$ & $\mathrm{HCC}$ \\
\hline $\begin{array}{l}\text { 43. I'm just happy not to be there. l'll never work for ___ who tell me that my } \\
\text { education isn't as good as theirs (because l'm not _ again. }\end{array}$ & *Supplementary \\
\hline 45. To replace us, the school did have to offer overseas status in the end!. & *Supplementary \\
\hline $\begin{array}{l}\text { 46. It was a wonderful school and I was sad to leave, but excited for the } \\
\text { opportunities in my next position. }\end{array}$ & $\overline{\mathrm{PA}}$ \\
\hline
\end{tabular}


48. I think given the high turnover at international schools, it's important for schools to have someone one staff (whether it be the HR person or business person or a lawyer) to help teachers figure out tax situations/laws. It's a very confusing situation to be in and had I known the details it probably would have prevented me from leaving the school when I did.

50. There is a web site that surveys schools. I will certainly check it out in future since apparently there have been complaints about this school. Question: How does the CIS not know about them?

56. Hope the school has changed its system since there has been a mass exodus of teachers every year.

59. Having what amounts to an absentee landlord makes this school both unmanageable and undesirable (both to educators and parents). Had this not been the case, had the owners more respect for education, this school would be palatable and a pleasant place to work. However, this business is poorly run, turning only a small profit and not turning out learners ready to take on the challenges and joys of their world.

60. All-in-all, it still was a wonderful experience! I will return to International teaching.

61. It was a very difficult situation and I was sad to leave, however, I made the best decision for me. As a role model, I always ask myself if this is the kind of behavior that I want to model. When the answer is "Yes," then I know that's the best decision for me. I made the choice and am happy with that!

62. I'm glad I'm not there and would NEVER recommend it to anyone. The turnover was very high when I left because we were treated LIKE CRAP and insulted. The Head Admin. told the entire teaching staff that we were '... worth no more than onions.'

63. I love the school a lot - my co-workers, the parents and my students. But the whole administrative leadership was just so bad that staying at the school is very unstable.

64. The only time I was treated well was after I resigned and they begged me to stay. By that time I could not trust them. My key point is that staff far away from home and in a contract with their UK home rented out have little option but to satisfy their first contract but will plan to leave a school where they are treated badly and lied to as soon as that contract ends.

$66 . \quad$ is a lovely country and the people there were very open minded and gracious. However, they allow administrators to be "little kings" because that is the way their culture is set up. It doesn't work well when people from the western world come to work and expect freedom of speech and a part in the decision making process.

\begin{tabular}{|c|c|}
\hline 67. Enjoyed my two years there - great people. & ${ }^{*}$ Supplementary \\
\hline $\begin{array}{l}\text { 68. If I could have moved the } \\
\text { school was a terrific place to be academically - it was merely the tension in the } \\
\text { country which caused me to leave. }\end{array}$ & $\mathrm{HCC}$ \\
\hline $\begin{array}{l}\text { 69. } 1992 \text { but the same system has been going on since the English School of } \\
\text { opened in about }\end{array}$ & *Ambig \\
\hline $\begin{array}{l}\text { 70. It could have been aborted, but wasn't in the grasp of perception (vision) of the } \\
\text { person in the leadership role. }\end{array}$ & $\overline{\mathrm{AL}}$ \\
\hline $\begin{array}{l}\text { 71. The second year I was at this school, they hired a new director. HE was able to } \\
\text { straighten out a good deal of these problems. He insisted the two people causing } \\
\text { the problems not work at the school as they are board members and it is a conflict } \\
\text { of interest. Things improved very much. Decisive and fair treatment of teachers } \\
\text { improved. I think that hiring certified and competent administrators is a must! for a } \\
\text { successful international school. Our school would never have hired an uncertified } \\
\text { teacher; why would two unqualified people think they could run an international } \\
\text { school of this size and scope? }\end{array}$ & $\mathrm{AL}$ \\
\hline
\end{tabular}

*High turnover, HCC *Supplementary

*High turnover

*Owner interference

(1)




\begin{tabular}{|c|c|}
\hline $\begin{array}{l}\text { 74. I hope this information is helpful for your program and I would like to teach } \\
\text { English as a Foreign Language again, preferably in Eastern Europe. Good Luck } \\
\text { with your research! }\end{array}$ & *Supplementary \\
\hline $\begin{array}{l}\text { 75. All I would say is that I learned much from this situation and have been wary } \\
\text { and observant when I accept a new assignment. I really try to go in not expecting } \\
\text { much and feel out the school and admin as I go along during the first month or so. }\end{array}$ & *Supplementary \\
\hline $\begin{array}{l}\text { 79. The administration was honest, fair, and very transparent. It's just the } \\
\text { administration's style of leading is not what I wanted or needed. Great school but in } \\
\text { the end... not what I wanted. }\end{array}$ & $\overline{\mathrm{PF}}$ \\
\hline 80. Response deleted - respondent ineligible & \\
\hline $\begin{array}{l}\text { 81. This school did very little to retain teachers. Teachers stayed because they } \\
\text { made friends and liked the host country. The overall feeling was that the school did } \\
\text { not treat teachers well. }\end{array}$ & $\overline{\mathrm{AL}}$ \\
\hline $\begin{array}{l}\text { 82. I loved my job, I loved the school, aside from common politics etc. I was just } \\
\text { ready to move. }\end{array}$ & PF \\
\hline $\begin{array}{l}\text { 83. Besides } 6 \text { out of } 7 \text { teachers leaving this school, the secretary went to part-time, } \\
\text { and the principal left, as did the headmaster. The founder would not listen to } \\
\text { teachers, parents or administrators. }\end{array}$ & $\begin{array}{l}\text { *Owner } \\
\text { interference }\end{array}$ \\
\hline $\begin{array}{l}\text { 85. It was a very good school organization wise and benefit-wise. Students from the } \\
\text { countries were sometimes very rude. }\end{array}$ & SD \\
\hline
\end{tabular}
foreign teachers in 1st-8th grades leave the school after two years when their contracts are finished (and a few just left anytime). They said the teachers are completely USED UP after two years. This applied to younger teachers as well as older teachers (the group I was in). When my contract was completed my best friend was the ONLY teacher who started with us on our two year contracts who stayed for a 3rd year. (She had formerly been an English teacher in , she was enjoying life in __ and she needed the money). The foreign teachers in the Lycee component of our school often renewed their contracts, as the students in the 9-12th grades got into the school based on very high scores on a national secondary school placement exam (and family money, of course). The secondary students were of a higher caliber of student and were more manageable than the 1 st - 8th grade students who were mainly admitted by an English entrance exam and a good transcript if they were transfers. The majority of students in the Lycee (around 600) had attended the school since Kindergarten. The graduates of our school go on to be the leading citizens of ___ (business, law, medicine, science, academics, politics and the arts). This has been an established fact for many maybe 20 or more years. Our school was founded in the 1870's. It became co-ed perhaps in the 80's. The elementary and middle school components were started in 1993. Note that parents enter their children in a lottery to get into the school sometimes before they are born!

\begin{tabular}{l|l}
\hline 88. Not really. Good luck! & *Supplementary \\
\hline $\begin{array}{l}\text { 91. It was a great school, community and life but we were not willing to compromise } \\
\text { our future financial stability to stay there. }\end{array}$ & Comp \\
\hline $\begin{array}{l}\text { 92. I would return to the school if I marry and have children as it would be a great } \\
\text { location to raise a family. }\end{array}$ & *Supplementary \\
\hline $\begin{array}{l}\text { 93. I enjoyed my time there, but knew it was time to move on, in an attempt to } \\
\text { broaden my professional horizons and seek advancement that was not possible in } \\
\text { this environment. }\end{array}$ & PA \\
\hline $\begin{array}{l}\text { 94. This school has a very high turnover. A number of very experienced } \\
\text { international teachers left at the end of yr } 1 \text { of a } 2 \text { year contract. They have huge } \\
\text { issues with retention of staff. }\end{array}$ & *High turnover \\
\hline $\begin{array}{l}\text { 95. I would have stayed had they come to me with some kind of olive leaf, but none } \\
\text { was offered, so / left. }\end{array}$ & *Ambig \\
\hline 96. The school has had very severe problems and is ranked among the poorest & WC \\
\hline
\end{tabular}




\begin{tabular}{|c|c|}
\hline $\begin{array}{l}\text { institutions in a number of school review websites. While they were better than } \\
\text { some, they have degenerated to the point where potential hires are being } \\
\text { encouraged to avoid that school and Kuwait itself, due to recent, unpleasant and } \\
\text { dangerous circumstances and actions of }\end{array}$ & \\
\hline 97. There was a large turnover for very similar reasons as stated in question 19. & *Ambig \\
\hline $\begin{array}{l}\text { 100. The student population consisted of about } 70-80 \% \\
\text { and spoiled) kids had been at the school since Kindergarten. They had their cliques } \\
\text { and did not let any international students in. Instead they would bully them as if their } \\
\text { lives depended on it. Since the parents were so powerful, nothing could be done. } \\
\text { Taking drastic measures would have meant loss of revenue and the school couldn't } \\
\text { afford that. We'll never take another job in a } \\
\text { one of the best decisions we've ever made. }\end{array}$ & SD, WC \\
\hline $\begin{array}{l}\text { 101. All internationals schools are NOT the same. Some offer much better } \\
\text { packages and quality working environment. European schools in particular offer } \\
\text { VERY low paying packages. We have never broken contract but perhaps we have } \\
\text { just be very careful/ lucky in our choice of placements. }\end{array}$ & *Supplementary \\
\hline $\begin{array}{l}\text { 102. The desire to gain PYP experience was a major factor in finding another } \\
\text { placement. I felt like I was stagnating in very early in my career. }\end{array}$ & PA \\
\hline $\begin{array}{l}\text { 103. Great school, exceflent personal support during a period of illness; excellent } \\
\text { professional opportunities .... sad to leave, particularly the country where my } \\
\text { children were fluent in the language on departure; a country they most associate } \\
\text { themselves with. }\end{array}$ & *Supplementary \\
\hline $\begin{array}{l}\text { 104. I did not relish working for someone who had no professional integrity and } \\
\text { respect for her staff. Staff, parents and children were being 'ripped off' and taken for } \\
\text { a ride. Her driving force was to make as much money for herself as possible. }\end{array}$ & *Profit incentive \\
\hline $\begin{array}{l}\text { 105. I loved working at that school and I loved the country and life there. I would } \\
\text { return there in a heart beat - if salaries were reinstated. }\end{array}$ & Comp \\
\hline $\begin{array}{l}\text { 107. Very happy to have left for educational, health and sanity reasons. Moved to a } \\
\text { good school now - a real school. }\end{array}$ & $\mathrm{PF}$ \\
\hline $\begin{array}{l}\text { 108. After I had resigned the Principal and Head of Secondary and Primary also } \\
\text { decided to leave. With them gone, the buffer between the Business management } \\
\text { personal and the school staff disappeared. There has been an increase in the level } \\
\text { of discontent of staff because of business decisions coming before the educational } \\
\text { welfare of the students and staff. }\end{array}$ & *Profit incentive \\
\hline $\begin{array}{l}\text { 111. International teaching pay/conditions have not kept up with the benefits } \\
\text { offered in Australia. Accommodation, lack of superannuation and lack of access to } \\
\text { cars etc. do not add up to a quality lifestyle. This is a real issue - younger teachers } \\
\text { are happy to work in these conditions but older teachers need to be attracted by } \\
\text { comparable or better conditions. }\end{array}$ & Comp, WC \\
\hline $\begin{array}{l}\text { 112. It was a fantastic school and the head teacher shielded us from the owners } \\
\text { and their agenda. }\end{array}$ & *Supplementary \\
\hline $\begin{array}{l}\text { 113. This particular school was difficult for many reasons and it was noted that } \\
\text { people often chose to leave after their first year. Housing, money, politics, support, } \\
\text { feeling appreciated ... are some reasons. I think one has to factor in the cultural } \\
\text { constraints and the fact that the school was private and for profit. Just a note: I } \\
\text { believe that there are so many other reasons for people breaking contracts or } \\
\text { leaving schools at the end of their initial contracts. My observation, although my } \\
\text { experience is limited, is that a lot of it has to do with the politics that run the school, } \\
\text { the work load, feeling valued and listened to, the lack of administrative consistency } \\
\text { and continuity which lead to trust issues, how the school runs in terms of its } \\
\text { effectiveness in the use of appraisal systems etc. I think there are a lot of team } \\
\text { building elements missing that essentially pull the staff together to work for the best } \\
\text { interests of the students they serve. I find it quite sad actually. Good luck with the } \\
\text { survey. }\end{array}$ & $\mathrm{AL}, \mathrm{HCC}$ \\
\hline 114. I enjoyed working at __ very much. I believe it is one of the better & *Supplementary \\
\hline
\end{tabular}




\begin{tabular}{|c|c|}
\hline & \\
\hline $115 . \quad$ is HOT & HCC \\
\hline $\begin{array}{l}\text { 129. Had fantastic colleagues in science department, would love to work with them } \\
\text { again! Think_ needs to show more support to staff. }\end{array}$ & $\mathrm{AL}$ \\
\hline 130. Of a staff of almost 70 people, 25 left this year. & *High turnover \\
\hline $\begin{array}{l}\text { 137. I was there when Sept. } 11 \text { occurred, so there was perceived future instability } \\
\text { in the region, so personal safety was also a factor criss-crossing the other reasons. }\end{array}$ & $\mathrm{HCC}$ \\
\hline 138. I enjoyed my time there very much. & *Supplementary \\
\hline 139. We liked the school but career prospects for an aspiring head were limited. & $\overline{\mathrm{PA}}$ \\
\hline $\begin{array}{l}\text { 141. Conditions for teachers were being regularly reduced and that continued after } \\
\text { I left. }\end{array}$ & *Ambig \\
\hline 142. Response deleted - participant ineligible & \\
\hline 143. Other teachers also left after one year & *Supplementary \\
\hline $\begin{array}{l}\text { 144. The quality of the teaching in the secondary section was very poor and all } 3 \\
\text { good teachers were leaving }\end{array}$ & ${ }^{*}$ Colleagues \\
\hline $\begin{array}{l}\text { 148. We loved living and working in } \quad \text {; the kids were fantastic, their parents } \\
\text { were very supportive, and staff were professionally talented and very sociable. If my } \\
\text { contract and salary had been significantly better, we would have stayed on } \\
\text { indefinitely. Since leaving l've taught in } 2 \text { more IB World schools in } \\
\text { a total of } 7 \text { years. I'll not be renewing my contract in because again, the } \\
\text { salary is not enough to comfortably cover living expenses and our mortgage. Sadly, } \\
\text { it seems salary and contract packages in international schools the world over are } \\
\text { following a downward trend these days and at job fairs, there are only a limited } \\
\text { number of schools I can even consider, as most pay less than } \$ 30 \text { o00 USD on } \\
\text { entry; this is about half what I would be making at home in Sydney and even with } \\
\text { the various differences in taxes and costs of living, we still need to maintain a } \\
\text { Sydney mortgage and an Australian pension plan. It seems that most international } \\
\text { schools are specifically targeting younger teachers, leaving mature and experienced } \\
\text { teachers with no choice but to head home to higher salaries and long term financial } \\
\text { security. Some of the better IB World schools in offer excellent } \\
\text { salaries/contract packages and we may return there if I can land a contract for next } \\
\text { SY; we left for personal reasons but can now go back, as that personal issue } \\
\text { has been resolved. }\end{array}$ & Comp \\
\hline 149. Couldn't $t$ afford to stay any longer, even though I was asked to stay & Comp \\
\hline $\begin{array}{l}\text { 150. A friendly place to work, reasonable workload and comforting support from the } \\
\text { management. }\end{array}$ & *Supplementary \\
\hline $\begin{array}{l}\text { 151. The best professional move I ever made = leaving the country and then } \\
\text { informing them later. It took them a couple of months to replace me amid a lot of } \\
\text { complaints from parents. They have since got their act together re. honesty but are } \\
\text { struggling to recruit people. I would like to believe that I contributed to this but if I } \\
\text { didn't I would do the same again elsewhere and fight for my integrity again against } \\
\text { any school regardless of who they are. }\end{array}$ & PA \\
\hline $\begin{array}{l}\text { 152. I'm so glad I left! I heard through the grapevine, that things have been getting } \\
\text { worse with the primary head bullying the staff and the director failed to show up to } \\
\text { deal with it. I believe that they were a few lawsuits against the school concerning } \\
\text { unlawful dismissal. }\end{array}$ & *Ambig \\
\hline $\begin{array}{l}\text { 158. The school administration was great. That was what made me stay the third } \\
\text { year. Although I was an elementary teacher, I taught the high school and middle } \\
\text { school principals' children. All admin were very friendly, helpful and made my stay at } \\
\text { the school, from the moment I arrived, better than I could have imagined! }\end{array}$ & *Supplementary \\
\hline $\begin{array}{l}\text { 159. No, I would say in general I have been unimpressed with the quality of } \\
\text { management in both my international schools, and feel that teaching internationally } \\
\text { is a bit like a slippery slope, meaning that the more time spent teaching outside of } \\
\text { my home country the more de skilled I become. Furthermore, the chances of getting } \\
\text { into a higher quality international school diminish the longer you are abroad. I am }\end{array}$ & $\mathrm{AL}$ \\
\hline
\end{tabular}


considering returning to the UK to re train in the UK state system the year after next, and then picking up my international career after that. In terms of not staying after my initial contract, I re signed for an extra year just now because I dearly love rather than any thing to do with the school. I would stick to a school long term if, I had greater confidence in the caliber of the people in charge, there were effective professional development systems and levels of resources and my future children were being educated there. I hope to find a school like this in the future and continue working in fascinating environments/cultures and having the great experience of seeing the world.

161. Difficult to teach within a school whose owners interfere with curriculum, teaching styles and even personal lives of all staff! Had similar difficulties in previous school (taught 3 years in northern ) and heard MANY similar tales from colleagues who taught in other schools. Very difficult to assess quality of both home and work life of schools in advance, came across many disappointed teachers who felt they'd been bought in as a "English-speaking status symbols" and were not respected as professionals

164. Loved the school and now that all has cleared, I would like the opportunity to return. I continue to be in contact with them as we "speak". Good luck with the dissertation. Cheers,

165. This school was new and required more experience amongst senior management than it had.

166. Huge lack of appreciation

168. The school has had major problems with the local teachers' union, and as a result, the salary scale has been virtually unchanged in over ten years.

Compensation is inadequate. Very complicated situation, but the end result is that the school has had major conflicts between overseas and locally hired teachers. Ironically, I left ___ in 1997 but have been living in again 2002 - present, as my husband's work is here, so I continue to know about the school. ! worked at again in the fall of 2002 for someone on emergency leave. I discontinued working there the second time as the salary really wasn't worth my while, and I now have two young children and prefer to stay home as a full-time mom.

169. A school with great potential and fantastic kids.

170. This was a good school and I was happy to be there. The decision to leave is always difficult but there is also the danger of getting stuck in a rut. The rate of turnover interests me though; I started a thread on the TES staffroom website (Overseas message board) and had some interesting comments. They may also interest you in your study. See this url if interested http:/ $/$ www.tes.co. uk/section/staffroom/thread. aspx?story id=23890138path=/Teach ing\%200verseas/

173. I enjoyed teaching there, the pupils were great, but management was not supportive enough for me to stay.

174. If it was standard practice to have 4 year contracts, we would have stayed for 4 years. When we were young, we thought that when you signed for 2 years, then you stayed for 2 years. We later learned that if you stay for much longer than 2 years, it gets hard to leave. However, our goal, then, was to see the world and teaching overseas gave us the means to do that. As we are older now, and have kids, we tend to want to stay a bit longer in each place, but have still not stayed more than 4 years.

178. Most sensible decision of my career. Have blotted out all memory of what was a nightmare year.

179. As the school was a profit school and not part of any group, such as the CIS, some of the things regarding fees paid by the parents, child expectations and general treatment of the staff and parents were shocking.

180. This was and is a great international school in a wonderful country. I left when on top and believe that the school is going from strength to strength.

*Owner interference *Supplementary $\mathrm{AL}$ AL Comp s

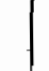

*Supplementary

*Supplementary

(


181. The experience caused me to lose faith in the accrediting associations. The school should never have been accredited or remained so considering the facts and misrepresentations.

183. I loved the school, the students, the faculty, the package and the life style. The primary reason for leaving was the air pollution.

184. Many of the times I have left International Schools was because I wanted to explore a new country, or needed a contrast to a hardship posting but this school was definitely because of the administration attitude and broken promises.

Everything else- country, travel opportunities, friendships, colleagues- was great! 188. I wasn't ready to leave __.. Unfortunately, the school won't offer me what I specialized in. The packages are poor due to the lack of subsidies.

190. This was my second international school that I left after one year: sadly the first (in ____ was due to family illness and this was due to my desire to achieve savings toward property. I aim to stay in my new school for four years.

191. My contract renewal meeting took place in November of my second year and the option was for a further two year contract, so I was agreeing to nearly three more years from when I made the decision. As I was unsure about the job at the time I decided to leave. If I had had to make the decision a few months later I would have stayed. By the time I left in the summer I did not particularly want to. If there had been an option for a further year rather than two I would have taken it. A year into the job seemed too early to make a decision to stay a further two years at the end of the initial two year contract.

192. It was a good school which treated its teachers well (perhaps rather too well it seemed to attract a lot of slackers who plan to stay until they die). It also pays well for Europe, although I am moving to where the pay is considerably better. I am not one of those teachers who expects a pay packet in a European school, but obviously it is an issue for recruitment at the school when they are competing for teachers with and . I have no regrets about taking the position there and have received unparalleled professional development opportunities while working there. Really I think it was just time to move on.

193. I wish my personal circumstances had been such that I could have stayed longer

194. This school is reputed to be one of the best my leaving was motivated by the conditions in the country and the attitude, behavior and culture of the natives.

195. This school has a huge reputation. People from as far as Malawi, Malaysia, and China have all heard of this scary school. In fact, if I say it was in know you've heard of it, too.

196. I enjoyed my time there and have not ruled out possibility of returning to Africa. Funny thing is I was happy at this school but in other international schools I have taught where I have stayed more than one contract, it is the professional attitude of the staff, or lack there of which is important in my decision - think there is an expectation to work hard and contribute to school - not always appreciated by staff.

197. Overall, I had an great experience working in ___. Actually, I am heading back to work there for another $2+$ years as a Kindergarten teacher.

200. The school has LOTS of potential. I would have loved the opportunity to explain to the owners why there were 34 staff leaving this year....but I'm sure they would not be interested...saving face \& all that jazz.

201. Many of the teachers were ___ nationals and are under trained for the teaching positions they hold-they are cheap to employ so are often hired over fully trained and qualified international teachers, the foreign teachers end up doing much of the work

202. I think I have just about covered it!

203. I was very sorry that the public-private partnership, which had worked so well, and made the school unique, was broken up in a manner which upset the whole

$\mathrm{AL}$ Comp PF, Comp 


\begin{tabular}{|c|c|}
\hline $\begin{array}{l}\text { staff, many of whom had invested so much in both French National (BOI) and IB } \\
\text { programmes over the years. }\end{array}$ & \\
\hline 205. I was getting tired of a lonely life and wanted to get married and settle down. & $\mathrm{PF}$ \\
\hline $\begin{array}{l}\text { 206. The best of my life and energy went to teaching and I feel I was extremely } \\
\text { unfairly treated in the last year. There were blatant signs of discrimination: gender, } \\
\text { age and nationality in the last school; but also gender discrimination in the other } \\
\text { international school before that. My experience of international schools is that the } \\
\text { celebration of differences remains very tokenistic and reserved to the student } \\
\text { population only. There is little tolerance of diversity in the teacher population (except } \\
\text { may be for those employed to teach their mother tongue) from management who } \\
\text { remains overwhelmingly representative of-and biased in favor of their American, } \\
\text { Canadian, English or Australian culture and colleagues. The } \\
\text { for instance is a far better model of a truly international school that the so } \\
\text { called international school of the same country. Will the recent change of } \\
\text { management bring some improvement? It is unlikely since much remains to be } \\
\text { done in the training and choice of managers in order to improve their appreciation } \\
\text { and outlook on what could truly qualify as international approaches to teaching. } \\
\text { International schools should put international education at the centre of their } \\
\text { endeavor and not only seek to ripe financial benefits from a multi-national student } \\
\text { population }\end{array}$ & $\mathrm{AL}$ \\
\hline $\begin{array}{l}\text { 207. The week I arrived I was told that the future was uncertain then was sent on a } \\
\text { training course for a week, I didn't know if the school would be open when I got } \\
\text { back! In fact it was. I handed in my notice and was asked to stay till the end of the } \\
\text { year, not term. I did this a s a good will gesture, but that made it difficult for me to } \\
\text { find a job on returning to the UK. I had not been given a relocation package, or any } \\
\text { incentives to go there and no help to depart. In fact I think I acted most properly but } \\
\text { was treated quite shabbily, I did not even get assistance to find an apartment. The } \\
\text { school was not run on a fair or diplomatic basis, it just gave the appearance of being } \\
\text { so. The atmosphere was one of gossip, rumor and the boss was something of a } \\
\text { bully. Meetings were scheduled on my days off (I was part time) and I had to come } \\
\text { in, unpaid, to attend or else knew nothing of what was going on. }\end{array}$ & AL \\
\hline $\begin{array}{l}\text { 209. Several other staff who had been at the school longer were also leaving for } \\
\text { the same reasons and I feel unless staff/administration/management relationships } \\
\text { improve others will quit next year. }\end{array}$ & $\mathrm{AL}$ \\
\hline 210. I think most of the problems stemmed from the For Profit status of the school. & *Profit incentive \\
\hline $\begin{array}{l}\text { 213. I am happy not to work there anymore! The school had an amazing potential } \\
\text { with motivated staff, good facilities, but bad administrators sank the school. } 32 \\
\text { teachers out of } 45 \text { left the school this year and the only thing that was said in a } \\
\text { meeting is "we can easily replace all of you". }\end{array}$ & $\begin{array}{l}\text { *High turnover, } \\
\text { AL }\end{array}$ \\
\hline $\begin{array}{l}\text { 214. I gave this proprietary school a chance, even having heard horror stories } \\
\text { about for-profit schools. But after my experience there, I will never work for a } \\
\text { proprietary school again. }\end{array}$ & *Profit incentive \\
\hline 217. Enjoyed all else. & *Supplementary \\
\hline 219. It was also time for me to change country - culturally ready to go! & $\mathrm{PF}$ \\
\hline $\begin{array}{l}\text { 220. As with most things - it turned out to be a good decision and we moved on to } \\
\text { bigger and better things, so actually a blessing in disguise! }\end{array}$ & *Supplementary \\
\hline 222. The HOS and principals have a reputation for unprofessional behavior & $\overline{\mathrm{AL}}$ \\
\hline $\begin{array}{l}\text { 223. At job fairs, the full contract should be available for perusal - not just a } \\
\text { commitment to sign }\end{array}$ & *Supplementary \\
\hline 225. Response deleted - participant ineligible & \\
\hline $\begin{array}{l}\text { 227. Most people newly hired left at winter break. I stayed the full contract time, but } \\
\text { I do regret that. }\end{array}$ & *Supplementary \\
\hline $\begin{array}{l}\text { 228. I loved living in } \\
\text { school was very welcoming and the parking at the school. The atmosphere in the } \\
\text { reason for my leaving was financial. I just couldn't afford to live in the city on that }\end{array}$ & Comp \\
\hline
\end{tabular}




\begin{tabular}{|c|c|}
\hline salary. & \\
\hline $\begin{array}{l}\text { 231. This teaching assignment was my first as a head teacher. I found the general } \\
\text { teaching practices in the school to be old fashioned and I felt overwhelmed by the } \\
\text { workload. I spent the first year of the contract wondering "What is wrong with me?" } \\
\text { because I did not feel I could conform to the expectations. During the second year, I } \\
\text { realized it was not me. That particular school had no right to hire a brand new } \\
\text { teacher, as they did nothing to make sure I could handle the work once I arrived. I } \\
\text { was even given classes outside my subject area that my veteran colleagues refused } \\
\text { to teach. }\end{array}$ & WC \\
\hline $\begin{array}{l}\text { 233. YES! It was the first time in my life I had an exit interview with CIS! The } \\
\text { school needs a Principal with true experience/leadership qualities and international } \\
\text { experience! How can they suddenly change } 900 \text { students to PYP with no staff } \\
\text { training, no resources or understanding of the system. Sadly one person left who } \\
\text { took the blame for most problems but the Principal should also be accountable! } 27 \\
\text { staff left! So sad the school messed up children's education! Now they are making a } \\
\text { new school for National Curriculum. Why didn't they just build a new school for PYP } \\
\text { instead of messing up the old school and now building a new one! }\end{array}$ & $\mathrm{AL}, \mathrm{WC}$ \\
\hline $\begin{array}{l}\text { 234. The situation was intolerable. The only people who stayed were those married } \\
\text { to with no other options. }\end{array}$ & ${ }^{*}$ Ambig \\
\hline 235. Would never work or recommend anyone to work there again!! & *Supplementary \\
\hline 236. I am very happy to be teaching where I am now!! & *Supplementary \\
\hline $\begin{array}{l}\text { 237. I loved the school in }{ }_{\text {family were nearer. They all loved }} \text { - was there } 9 \text { years - would have stayed for ever if } \\
\text { too! }\end{array}$ & $\mathrm{PF}$ \\
\hline $\begin{array}{l}\text { 239. We loved our school and our life in } \\
\text { years and we have also considered returning to the Int'I school 'system' sometime } \\
\text { in the future. We think that annual home leave is important in a country that is very } \\
\text { different from the home country. }\end{array}$ & *Supplementary \\
\hline $\begin{array}{l}\text { 241. The only benefit from those two years was that I gained experience to allow } \\
\text { me to be a more interesting candidate at other schools. }\end{array}$ & $\overline{\mathrm{PA}}$ \\
\hline $\begin{array}{l}\text { 243. School is crumbling and with each new director, principal, board things get } \\
\text { forgotten, changed without thought as to the long term future of the school. It is very } \\
\text { unstable and has had financial problems and this affects staff morale so much that } \\
\text { many people who can leave and many want to but can not. Many people are } \\
\text { stressed and are not being supported. }\end{array}$ & *High turnover \\
\hline $\begin{array}{l}\text { 247. The students were great and I did not want to leave the school because of } \\
\text { them, which makes the situation very unfortunate. }\end{array}$ & *Supplementary \\
\hline $\begin{array}{l}\text { 250. I believe that it is a very good school where teaching staff enjoyed working } \\
\text { with the students. It is a dynamic learning institution, especially considering its rapid } \\
\text { growth, but it was not the place for me at this stage of my career. Had I worked fully } \\
\text { in one of the other departments of the school, e.g. Math or Humanities, my } \\
\text { responses may well have been very different. }\end{array}$ & $\mathrm{PF}$ \\
\hline $\begin{array}{l}\text { 251. The Head covered up an incident of a student who cheated in an IB exam so } \\
\text { she would get a monetary prize awarded by the PTA. The Head has since lost his } \\
\text { job. }\end{array}$ & *Supplementary \\
\hline 254. Many teachers left. There was nearly $50 \%$ turnover. & ${ }^{*}$ High turnover \\
\hline $\begin{array}{l}\text { 255. I do not miss it. I do not miss } \quad \text { I do not miss the food. I do not miss } \\
\text { (trying) to learn the language. I miss the students. }\end{array}$ & $\mathrm{HCC}$ \\
\hline $\begin{array}{l}\text { 256. I returned to the school as an administrator and have been there three years } \\
\text { now. No intention of leaving just yet! Very happy! I would very much like to see a } \\
\text { copy of your findings if at all possible. I realize that giving my email address will } \\
\text { identify the school. I trust that all comments will be treated in confidence. Thank } \\
\text { you. Good luck with this important study. }\end{array}$ & *Supplementary \\
\hline $\begin{array}{l}\text { 257. I would recommend always traveling to the school before signing a contract to } \\
\text { experience the everyday workplace before deciding. }\end{array}$ & *Supplementary \\
\hline 259. I don't think this cycle is going to be abated while new recruits eager for & *Supplementary \\
\hline
\end{tabular}




\begin{tabular}{|c|c|}
\hline $\begin{array}{l}\text { international experience are readily available: administrators can feed off of that } \\
\text { while ignoring systemic problem of high turn-over rates among even experienced } \\
\text { teachers. }\end{array}$ & \\
\hline $\begin{array}{l}260 \text {. It was very sad leaving, the faculty of foreign teachers and } \\
\text { teachers worked collectively to provide an effective bilingual education. I would } \\
\text { return to the school if there was a drastic change in management. I was forced to } \\
\text { take unpaid leave and pay for my own flights and costs, to present a discussion } \\
\text { paper at an international conference in another country. The three-day conference } \\
\text { was over a weekend and I was charged for being absent from the school for three } \\
\text { full teaching days. }\end{array}$ & $\mathrm{AL}$ \\
\hline $\begin{array}{l}\text { 262. This is GOOD SCHOOL - but much thought needs to be given with regard to } \\
\text { retaining good staff }\end{array}$ & *Supplementary \\
\hline $\begin{array}{l}\text { 263. I enjoyed my teaching although I felt that the facilities/ resources could have } \\
\text { been much improved. }\end{array}$ & WC \\
\hline $\begin{array}{l}\text { 264. Overall my international school teaching experience was positive and I would } \\
\text { do it again perhaps in a different school in another country. }\end{array}$ & *Supplementary \\
\hline $\begin{array}{l}\text { 265. I was relieved to leave this school as it drained the life out of me. It was a dull, } \\
\text { grey place from which a passion for educating young people had been sucked. I } \\
\text { have recently worked at another international school where teachers were housed } \\
\text { in a dreadful part of the city where very few residents actually spoke the language of } \\
\text { the country, whilst the administration lived in lovely circumstances. A number of } \\
\text { colleagues and I left the school at the end of a } 1 \text { year contract as we felt that we had } \\
\text { been treated very poorly. At another school I was given a nice apartment but in the } \\
\text { middle of a building site. It's really important for schools to help teachers to find } \\
\text { homes in suitable areas. It's really hard to do this at the start of the school year } \\
\text { when there are meetings to attend every day. }\end{array}$ & *Supplementary \\
\hline 271. My partner and I later regretted leaving & *Supplementary \\
\hline $\begin{array}{l}\text { 272. Nice staff, great kids, was being run by two managers who could not organize } \\
\text { their way out of a paper bag. Head of secondary was great but his hands were tied. }\end{array}$ & $\mathrm{AL}$ \\
\hline $\begin{array}{l}\text { 277. We did not want to leave the country or the school. It was the best school } \\
\text { environment, package etc we had ever had. We left because I was offered a } \\
\text { position of Special Needs Coordinator in }\end{array}$ & PA \\
\hline $\begin{array}{l}280 \text {. The student culture of violence and bullying was not addressed in a } \\
\text { meaningful sense. Moreover the parents and alumni say they want to make positive } \\
\text { changes but do not support actual changes made. }\end{array}$ & SD, WC \\
\hline 282. We would quite like to go and work there again some day. & *Supplementary \\
\hline $\begin{array}{l}\text { 284. I loved the school. One of the main reasons I became an international teacher } \\
\text { was to see the world and experience different cultures. I had spent } 5 \text { years in } \\
\text { at } 2 \text { different schools and wanted to return to } \\
\text { at a school. I feel I need at least that amount of time to make a significant } 3 \text { years } \\
\text { contribution. }\end{array}$ & PF \\
\hline $\begin{array}{l}\text { 285. Things remain so bad at this school } \\
\text { various sites to warn others. Others have done the same in the hope that what was } \\
\text { once a lovely school will receive the enlightened leadership it deserves. }\end{array}$ & $\overline{\mathrm{AL}}$ \\
\hline
\end{tabular}

